$$
\begin{gathered}
\text { Universidade de São Paulo } \\
\text { Instituto de Psicologia }
\end{gathered}
$$

Programa de Pós Graduação do Departamento de Psicologia Social e do Trabalho

\title{
Mal Estar no Trabalho da Hipermodernidade: \\ Seis Dimensões observadas na Clínica e suas consequências
}

Orientadora: Prof ${ }^{a}$ Dra. Yvette Piha Lehman Autor: Francisco Rodrigues Alves de Moura 
Universidade de São Paulo

Instituto de Psicologia

Versão Corrigida

\section{Mal Estar no Trabalho da Hipermodernidade}

Seis Dimensões observadas na Clínica e suas

consequências

Dissertação apresentada ao Programa de Pós Graduação do Departamento de Psicologia Social e do Trabalho

Orientadora: Prof ${ }^{a}$ Dra. Yvette Piha Lehman

Autor: Francisco Rodrigues Alves de Moura

Nível: Doutorado

São Paulo

$1^{\circ}$ Semestre de 2019 
AUTORIZO A REPRODUÇÃO E DIVULGAÇÃO TOTAL OU PARCIAL DESTE TRABALHO, POR QUALQUER MEIO CONVENCIONAL OU ELETRÔNICO,

PARA FINS DE ESTUDO E PESQUISA, DESDE QUE CITADA A FONTE.

Catalogação na publicação

Biblioteca Dante Moreira Leite

Instituto de Psicologia da Universidade de São Paulo

Dados fornecidos pelo(a) autor(a)

Moura, Francisco Rodrigues Alves de

Mal Estar no Trabalho da Hipermodernidade: Seis Dimensões observadas na

Clínica e suas consequências / Francisco Rodrigues Alves de Moura; orientadora

Yvette Piha Lehman. -- São Paulo, 2019.

$200 \mathrm{f}$.

Tese (Doutorado - Programa de Pós-Graduação em Psicologia Social) -- Instituto de Psicologia, Universidade de São Paulo, 2019.

1. Psicanálise. 2. Reconhecimento. 3. Autonomia. 4. Hipermodernidade. 5. Violência. I. Lehman, Yvette Piha, orient. II. Título. 
Nome: MOURA, Francisco RodRIGUes Alves dE

Título: MAL EstAR NO TRABALHO DA HIPERMODERNIDADE: SEIS DIMENSÕES OBSERVADAS NA CLÍNICA E SUAS CONSEQUÊNCIAS

Dissertação apresentada ao Programa de Pós Graduação do Departamento de Psicologia Social e do Trabalho para obtenção do título de Doutor em Psicologia

Aprovado em:

Banca Examinadora

Prof. Dr. :

Instituição:

Julgamento:

Prof. Dr. :

Instituição:

Julgamento:

Prof. Dr. :

Instituição:

Julgamento:

Prof. Dr. :

Instituição:

Julgamento: 
PARA EVELIN WANKE 


\section{Agradecimentos}

Agradeço à minha inspiradora, paciente e criativa orientadora, Professora Yvette Piha Lehman. Sem seu apoio e cuidado constante, seria impossível chegar até aqui. Sem contar com os almoços, carinho e pelas incontáveis lições que aprendi. Mais que orientar uma tese, a senhora orientou uma transformação de vida.

Agradeço à Professora Tânia Casado por seu imenso apoio, assim como pelas oportunidades que proporcionou ao longo desta pesquisa. Além das aulas, trocas e interações, foi fundamental para compartilhar essas ideias pelo mundo.

Agradeço à Universidade de São Paulo e ao Departamento de Psicologia Social e do Trabalho pelo apoio e acolhimento a esta pesquisa; mais uma vez, cada um de vocês me proporcionou uma jornada inesquecível de aprendizado, outra dívida que terei com essa instituição que me formou.

Agradeço ao essencial autor Cristophe Dejours, fonte inquestionável de interlocução, reflexão e estudo. Mesmo em um contato breve, a chama queimou.

Agradeço ao Professor Doutor Nelson da Silva Júnior e ao Professor Doutor José Paulo Fiks pelas contribuições essenciais durante meu exame de Qualificação, além das inúmeras outras ao longo deste caminho.

Agradeço ao Doutor Andres dos Santos Júnior por seu apoio constante, seus desafios e pela força que me emprestou em momentos essenciais desta jornada.

Agradeço a Maria Thereza Toledo Rodrigues Alves e Denise do Rocio Wanke por sua leitura paciente, atenta e por sua ajuda no estabelecimento deste texto.

Agradeço enfim a todos analisandos e entrevistados por suas histórias, histórias tristes que inspiraram este trabalho. Espero que contribua em mudar um pouco de suas relações com o trabalho, e, quem sabe, ajudar em buscar escolhas melhores neste universo cada vez mais incerto. 
RESUMO

Desde a origem da coletividade humana, o trabalho tem um papel potencialmente estruturador ou, por vezes, patológico na integração do indivíduo na sociedade e cultura. Nas últimas décadas, o aspecto do mal estar faz-se mais e mais evidente para os profissionais da saúde mental.

O objetivo desta pesquisa é apontar como o mal estar no trabalho na contemporaneidade estaria intimamente ligado a três elementos essências e, inevitavelmente, conectados entre si. O componente inicial é o intrasubjetivo, relativo à formação e desenvolvimento do psiquismo na esfera do indivíduo, ou da sua psicopatologia. Nesta esfera seriam centrais os temas do reconhecimento e a autonomia (ou relação do sujeito com o tempo aliado à latitude em decidir por si). Em torno - e complementar a esta dimensão - existem as relações de trabalho, nas quais predominam os temas da violência no ambiente de trabalho e do desequilíbrio da dinâmica entre espaço privado e espaço compartilhado (ou público).

No entanto, a análise do mal estar no trabalho seria incompleta se não envolvesse uma terceira dimensão: a do funcionamento social e cultural da contemporaneidade, molde e prensa para concepções pré-formadas e compartilhadas sobre o trabalho e seu valor na sociedade e na cultura. É neste campo que influiriam não somente promessas irreais em relação ao trabalho, traduzidas como sentido ou propósito, e, por fim, o efeito das personalidades hipermodernas e do mercado de consumo.

Psicanálise, Psicopatologia e Psicodinâmica do Trabalho, Filosofia e Sociologia propõem soluções importantes, que teriam maior impacto se considerassem um entrelaçamento essencial entre estas dimensões da relação do eu com o outro, os direitos individuais e coletivos, e uma perspectiva social e compartilhada de coletividade. A Psicologia Social e do Trabalho, em sua transmissão e prática, deve adotar uma leitura multidimensional para compreender, ensinar, prevenir e tratar o mal estar contemporâneo em relação ao trabalho.

Palavras chave: Psicologia Social, Psicanálise, Reconhecimento, Autonomia, Violência, Assédio, Público/Privado, Propósito, Hipermodernidade, Estresse, Trabalho. 


\section{Abstract}

From the dawn of human collectiveness, work has had a potentially structuring role, or, at times, a pathological influence in the subject's selfness in Society and Culture. Over the past six decades, the aspect of discontent is increasingly conspicuous for mental health professionals.

The purpose of this research is to analyze how this discontent is closely related to three essential elements, that are, inevitably, interconnected amongst themselves. One is imminently intersubjective and relates to the structuring of subjectivity and the development of the psyche in an individual sphere; in other words, its psychopathology. In this sphere, the core themes would be connected to a lack of recognition and autonomy (regarding the relationship with time management and/or latitude to make decisions). Encompassing this dimension - and interdependent - are the workplace relationships, in which themes such as violence in the workplace and an unbalance between private and shared space dynamics are predominant.

However, analyzing stress and work-related discontent would be incomplete without a third dimension, corresponding to social and cultural motions of current times. Workplace culture and our shared social values are both mold and shape for pre-formed notions amongst individuals, and these elements contribute to perceptions that lead to unreal expectations towards work and are showcased as purpose or meaning at work. The final dimension relates to the effect of what is called hypermodern personalities in a consumeoriented and neo liberal market.

Psychoanalysis, Psychopathology and Work Psychodynamics, Philosophy and Sociology propose essential solutions, but would benefit from a proper interrelation amongst these dimensions of the relationship between the self and the other, individual rights and collective ones, as well as a social and shared perspectives of collectiveness. Organizational and Social Psychology, in its teaching and practices, should adhere to a multidimensional perspective to understand, foster, prevent and intervene in our current times' discontent towards work and its vicissitudes.

Key words: Social Psychology, Psychoanalysis, Recognition, Autonomy, Violence, Harassment, Public/Private, Purpose, Hypermodernity, Stress, Work. 


\section{SUMÁRIO}

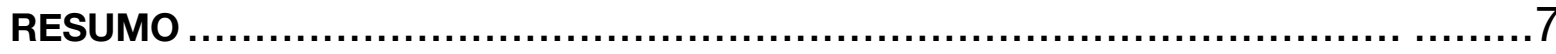

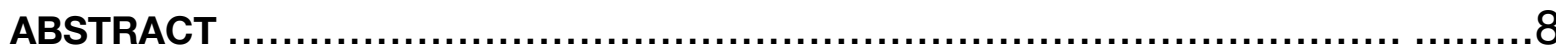

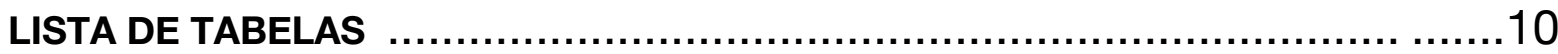

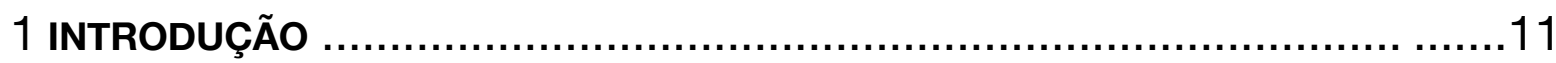

2. TRABALHO, EMANCIPAÇÃO, MAL ESTAR: A CONDIÇÃO HUMANA ................20

3. AS MÚLTIPLAS FASES DA “CLÍNICA DO TRABALHO” FRANCESA....................34

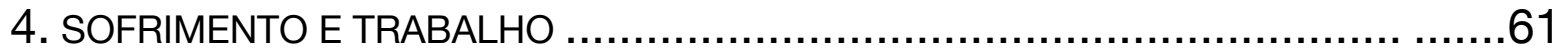

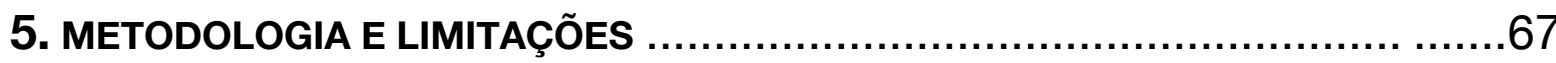

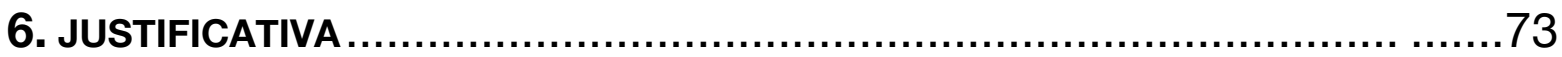

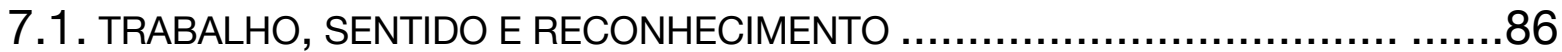

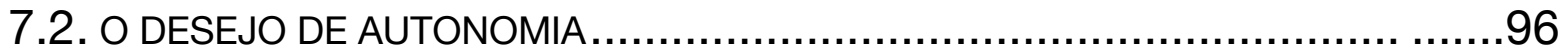

7.3. A TENSÃO ENTRE PÚBLICO E PRIVADO ......................................109

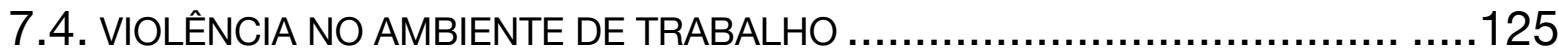

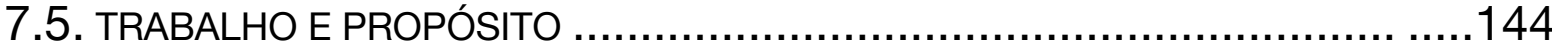

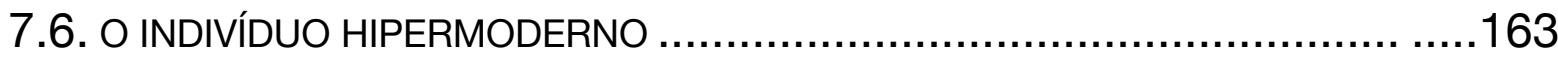

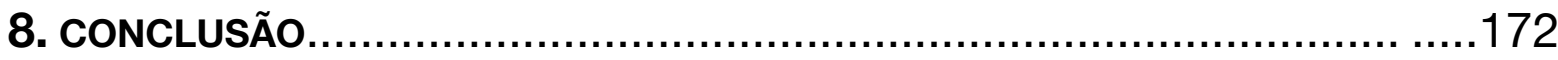

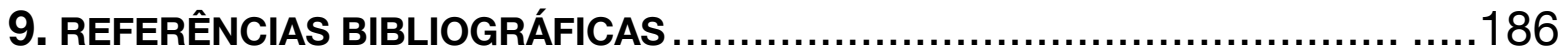




\section{LISTA DE TABELAS E FIGURAS}

TABELA 1: ESTRUTURA DAS RELAÇÕES SOCIAIS DE RECONHECIMENTO...........78

TABELA 2: MAPEAMENTO DE CAMPO DO TRABALHO CONTEMPORÂNEO..........79

FIGURA 3: SEIS DIMENSÕES OBSERVADAS NA CLÍNICA ...........................174 
Cenários desabarem é coisa que acontece. Acordar, bonde, quatro horas no escritório ou fábrica, almoço, bonde, quatro horas de trabalho, jantar, sono e segunda terça quarta quinta sexta e sábado no mesmo ritmo, um percurso que transcorre sem problemas a maior parte do tempo. Um belo dia, surge o "por quê" e tudo começa a entrar numa lassidão tingida de assombro. "Começa", isto é o importante. A lassidão está no final dos atos de uma vida maquinal, mas inaugura ao mesmo tempo um movimento da consciência. Ela o desperta e provoca sua continuação. A continuação é um retorno inconsciente aos grilhões, ou é o despertar definitivo.

(Camus, 2010. P. 27)

INTRODUÇÃO'

Nas últimas décadas. é possível afirmar sem dúvida que o trabalho e seu significado social, identitário e mesmo existencial adquiriram um status jamais alcançado na vida humana. Nunca houve tamanho investimento afetivo, ou tanto adoecimento associado às condições de trabalho, embora na maioria dos casos as suas condições objetivas tenham - ao menos em padrões pragmáticos ou ergonômicos - melhorado significativamente. Nosso objetivo é mapear a literatura especializada no campo do mal estar no trabalho para oferecer uma nova hipótese cujo intuito será melhor equipar profissionais de saúde mental na prevenção e tratamento de demandas que, ao menos inicialmente, estejam relacionadas a estas condições. Por se tratar de um campo extremamente fértil e, em certa medida, pouco unânime, irá se basear na análise de textos consagrados da psicanálise, psicopatologia e psicodinâmica do trabalho e, em contraponto, textos mais recentes que tratam de tendências mais recentes deste 'mercado'. Nossa questão fundamental nasce na noção bastante equivocada do "sofrimento no trabalho", e busca criar novas chaves de entendimento sobre fenômenos que cada vez mais inundam a clínica individual em suas múltiplas facetas e aliam a relação do trabalhador com seu ofício a temas centrais da

\footnotetext{
${ }^{1}$ Algumas ideias preliminares deste trabalho foram apresentadas na $76^{a}$ reunião da Academy of Management, em Annaheim, Estados Unidos, em 9 de Agosto de 2016, sob o título "Six Proposals on Workplace Suffering: Hyperodern Times and Impacts on Career Development", com co-autoria da Prof. Dra. Tania Casado, da FEA-USP.
} 
experiência humana como o reconhecimento, autonomia e outros temas colhidos

tanto na literatura como em nossa própria experiência clínica e profissional.

Dejours, em sua obra de 2012 intitulada "Psicopatologia do Trabalho" ('Psychopathologie de travail', com coautoria de Isabele Gernet), ressalta algumas das variações do termo 'sofrimento' em um capítulo intitulado 'O trabalho entre sofrimento e prazer' (Dejours, C., Gernet, I., 2012. P. 10). Neste texto, ressalta as múltiplas variações empregadas por autores para se aproximar do tema escorregadio do 'sofrimento' no trabalho: stress, mal estar, fadiga, e mesmo a definição da OMS do 'stress psicossocial'. É interessante a menção que faz em seguida do modelo de Karasek e Theoreli, de 1990, para avaliação de "fatores psicossociais no trabalho: a autonomia (falha, ou forte), que permite atuar frente às decisões [da hierarquia?]; as exigências (fracas ou fortes) que correspondem às pressões de tempo e à atividade" (lbid.).

Na continuação deste texto, o autor posiciona o conceito de sofrimento na clínica do trabalho.

O retorno aos problemas colocados pela clínica do trabalho permite situar o "sofrimento" como um conceito crítico pertinente, fundado sobre referências teóricas endereçadas à psicopatologia geral, a psicanálise e a psicosomática. Se o sofrimento psíquico - enquanto tal designado como uma prova singular da experiência de uma vida psíquica - pode ser um objeto de consenso entre os clínicos, ele suscita não obstante discussões no campo das ciências humanas, notadamente do risco de 'psicologização' dos fenômenos sociais que este conceito seria capaz de veicular (A. Ehrenberg, 2010; O. Douville, 2004)². Mesmo que ele seja sempre passível de se limitar ao tratamento empático do sofrimento, sabemos que do ponto de vista clínico, isso seria insuficiente. O sofrimento, enquanto vivência subjetiva, reenvia sempre a uma experiência singular ligada a situações e práticas específicas de trabalho.

(Dejours, C. Gernet. I., 2012. P. 11, trad. livre)

\footnotetext{
${ }^{2}$ A respeito desta - e outras - passagens de Dejours, vale retomar um comentário que Yves Clot fez em seu favor; em um dos trechos finais de seu 'Le Travail à Coeur' (que poderia ser lido tanto como 'O trabalho no coração' ou como 'a centralidade do trabalho'), Clot se posiciona especificamente em relação às críticas de sociólogos e outros autores de orientação Marxista quanto à obra de Dejours. Em sua leitura, Dejours não 'psicologiza' a questão do trabalho em detrimento de uma leitura política, mas faz exatamente o contrário o contrário: ele 'politiza' o psicológico". (Clot, 2015. P. 158) Poderia servir, por exemplo, como uma resposta pública a textos recentes de autores como Bernard Doray, já citado anteriormente.
} 
A clínica também mostra reflexos desta transformação da cultura e dos modelos identitários (ou imaginários); estes efeitos na subjetividade ${ }^{3}$ são relativo consenso entre os pesquisadores, como por exemplo o autor francês Bernard Doray (2011):

"Nas últimas décadas, era muito raro que um paciente trouxesse espontaneamente um sofrimento principalmente imputado ao trabalho em uma consulta psiquiátrica de serviço público, enquanto hoje em dia, é o caso ao menos um décimo dos usuários do subsetor que me é familiar".

(Doray, 2011, P. 203. trad. livre)

Assim como Doray, a socióloga francesa Daniéle Linhart também comenta sobre a percepção de um aumento no ‘sofrimento' no trabalho: “Embora essa condição se imponha cada vez mais como "natural" [a precariedade material e a perda de autoestima], inevitável, ela se revela, na realidade, cada vez mais incômoda. Prova disso é a extensão do sofrimento no trabalho, que se tornou onipresente. Tal degradação precisa ser relacionada à individualização crescente da relação assalariada". (Linhart, 2017. P. 16)

Experiências de trabalho vitalizantes contribuem amplamente para o bem-estar e felicidade ${ }^{4}$. No entanto, o oposto também é verdadeiro: se o trabalho tem o potencial de ser um campo de realização e desenvolvimento, experiências negativas ou mesmo traumáticas na vida de trabalho podem ter um efeito emocional e físico devastador ${ }^{5}$.

\footnotetext{
${ }^{3}$ Definir subjetividade seria uma tese em si; nossa perspectiva é que subjetividade não seria o oposto de 'objetividade. Desde a filosofia moderna, é impossível pensar em sujeito e mundo como entidades separadas. Desta forma, subjetividade será oposto à 'intersubjetividade' (ou intersubjetividade intrapsíquica, para ser mais preciso). Se por intersubjetivo imaginamos o indivíduo em sua interação com o outro (ou mesmo 'o outro dentro de si'), na subjetividade referimos traços individuais, história, experiências e memórias transicionais e mais relacionadas às estruturas psicológicas do sujeito e seus traços idiossincráticos. Poderíamos usar a subjetividade como análoga ao conceito freudiano de 'mundo interno', por exemplo.

${ }^{4}$ Há uma singela passagem de Marie Pezé que estrutura essa ideia: "Certamente, o trabalho está em forte ressonância simbólica com nossa identidade pessoal, nossa história infantil, e o veremos em todos os pacientes". (Pezé, 2010. P. 5, trad. livre)

${ }^{5}$ Há centenas de estudos que fortalecem esta hipótese de crescimento da percepção, incidência ou sensibilidade ao sofrimento no trabalho. Para citar alguns: Lucero, M. A. , Allen, R. E. The Role of Provocation in Workplace Violence: Reviewing Published arbitration Cases. (2014); Hewett, R. Liefooghe, A.P.D., Visockaite, G., Roongrerngsuke, S. Bullying at Work: Cognitive Appraisal of Negative Acts and the Impact on Wellbeing and Performance. (2014); Laschinger, H. S., Fida, R. Longitudinal Analysis Authentic Leadership on Workplace Bullying, Burnout and Turnover
} 
Se constata algo de trágico: o sistema, que atualmente gera um sofrimento até então inédito no mundo do trabalho, não funciona senão pelo nosso zelo e a inteligência que colocamos em prática conjuntamente para fazê-lo perdurar. ${ }^{6}$

(Dejours et Al., 2015. P. 9-10, trad. livre)

O tema da realização no trabalho certamente traz uma série de críticas; os filósofos franceses Sidi Mohammed Barkat e Éric Hamraoui estão entre os autores que criticam esta noção tão comum na contemporaneidade.

A organização do trabalho é atualmente colocada em cena como um lugar de realização de si (l'accomplissement de sol), desqualificando o dispositivo tradicional da realização da atividade: coletivos de trabalho, movimento social e instituição do Direito. O indivíduo, que enxergava neste dispositivo a garantia de uma realização efetiva da atividade de trabalho, encontra-se não obstante projetado para além da cena, mas só. É esperado que ele seja assim o alfa e ômega de sua própria vida. É nesta perspectiva que ele é declarado não somente autônomo, mas livre.

(Barkat, S. M., Hamraoui, E. 2009)

Além da ideia de que experiências profissionais possam ser geradoras de demandas clínicas, um tema essencial para ser criticado é o da própria validade do conceito de 'satisfação' no trabalho. Iremos explorar estas noções - e algumas de suas potenciais origens - mais adiante, mas podemos iniciar questionando se as organizações deveriam ter a responsabilidade por assegurar a felicidade de seus empregados. Muitos trabalhos acadêmicos dissolvem este dilema pela substituição da discussão sobre satisfação por outros conceitos mais

Intentions. (2014); Cowan, R. Salin, D. Human Resource Professionals' Perceptions of Workplace Bullying from Across the Globe. (2014); Jacobson, R. P., Hood, J. N. Jacobson, K. J. L. Moral Emotions as Predictors of Workplace Bullying: Reducing the Likelihood of Bullying Perpetration. (2014). Se formos buscar outros meios, podemos citar o trabalho de Christophe Dejours, em especial seu trabalho de fevereiro de 2015 intitulado "Le Choix: Souffrir au Travail n'est pas une fatalité" (2015).

${ }^{6}$ Para mais uma referência a este fenômeno e, em especial, ao intenso potencial mercadológico que ele revela, ver o artigo de 25 de novembro de 2018 do Jornal Folha de São Paulo: "Crise no emprego eleva em 1,6 milhão o número de consultas psiquiátricas". Segundo a pesquisa da repórter Érica Fraga, "dados da ANS revelam que o número de consultas psiquiátricas saltou de 2,9 milhões em 2012 para 4,5 milhões em 2017. O aumento de 54\% é o quíntuplo dos 10\% registrados no mesmo período de consultas ambulatoriais em geral". Nos primeiros nove meses de 2018 o INSS registrou mais de 8.000 pedidos de afastamento por questões relacionadas a problemas no trabalho, uma alta de $12 \%$ em relação ao ano anterior. 
precisos como auto realização, auto atualização, individuação e outros derivados. ${ }^{7}$

A ideia contemporânea de que o trabalho deveria ser satisfatório - ou ainda, uma fonte inexaurível de felicidade - não é uma transformação pós moderna. Hannah Arendt, em seu trabalho "A Condição Humana" (2008) publicado originalmente em 1958 já trazia à luz a ideia de que o trabalho em uma sociedade trabalhadora (ou laboriosa) é fonte da felicidade nasceu como efeito colateral do capitalismo de consumo. Com a aceleração tanto da produção como o caráter facilmente perecível dos produtos, sua depreciação, obsolescência programada e as forças de marketing deixam pouco refúgio ao indivíduo.

O resultado do que é eufemisticamente chamado de cultura de massa e sua profundamente enraizada confusão é uma infelicidade universal, causada por um lado pelo equilíbrio confuso entre trabalho [laboring] e consumo e, por outro lado, as demandas persistentes do animal laborans de obter uma felicidade que só pode ser alcançada quando os processos de exaustão e regeneração da vida, de dor e alívio da dor encontrarem um balanço perfeito. A demanda universal por felicidade e a infelicidade espalhada em nossa sociedade (e esses são dois lados da mesma moeda) estão entre os sinais mais persuasivos de que começamos a viver em uma sociedade laboral na qual falta trabalho [labor] suficiente para mantê-la satisfeita. Pois somente o animal laborans, e jamais o artesão ou o homem de ação, jamais demandou ser "feliz" ou imaginou que homens mortais poderiam ser felizes.

(Arendt, 2008. P. $132-133$ )

\footnotetext{
${ }^{7}$ Uma síntese dessas análises pode ser encontrada no trabalho de Carol Ryff, que cita autores cuja obra explora esses temas: C. Rogers, com a pessoa plenamente funcional (Fully Functioning person), Allport, Maturidade (Maturity), Neuegarten, Processos executivos da personalidade (Executive processes of personality), Buhler, Tendências básicas da vida (Life's basic tendencies), Jung, Individuação (Individuation), Maslow Auto atualização (Self-actualization) e outros. (Ryff 1995) Poderíamos acrescentar a esta lista o filósofo Axel Honneth - que estudaremos em maior profundidade no conceito da luta pelo reconhecimento - em seu comentários detalhado de como o conceito clássico de 'honra' evoluiu gradativamente à 'dignidade' jurídica e à 'integridade' ou 'prestígio' na esfera social, o que abre caminho para formas de autorealização, essencialmente ligadas à cultura de sua época histórica. (Honneth, 2015. P. 206-7)
} 
Essa reflexão é fundamental para articular um ponto de vista clínico ${ }^{8}$ a uma realidade social do trabalho9: se o trabalho, ou mais especificamente as relações entre homens e mulheres com o trabalho são fenômenos essencialmente sociais, ao entrarmos na esfera da felicidade ou da realização - e mais ainda, da infelicidade e falta de realização - temos que olhar através de dois prismas. $O$ indivíduo da contemporaneidade hipermoderna ${ }^{10}$ amplificou sua busca pelo prazer e pelo consumo instantâneo de soluções rápidas para a angústia. Essa transformação também se vê refletida no tecido social e agravada por novos modelos de gestão que estimulam a hipercompetitividade interna e externa, a

\footnotetext{
${ }^{8}$ Assim como Arendt, Freud também articulou sua teoria em bases bastantes semelhantes. Como citado por Nelson da Silva Jr., "Segundo Freud, esta equação [como alcançar a realização frente às exigências da sociedade civilizada] não se resolve, e seu resto é o mal-estar, o sofrimento humano inerente à vida civilizada. Pois se a interdição do gozo é a condição da civilização, o sofrimento que disso decorre deve ser considerado como constitutivo. Por conseguinte, a própria ideia de cura deverá tomar uma outra definição que aquela oposta à doença, ou da redução dos órgãos a um silêncio fictício. (...) Dito de outra forma, não existe cultura sem o sofrimento que the seja próprio, e, de certa forma, necessário." (Silva Jr., 2014. P. 30, trad. livre)

${ }^{9}$ Outro autor que ressalta a importância da obra de Arendt é Christophe Dejours. No Segundo volume de seu "Trabalho Vivo" (Travail Vivant, 2: Travail et émancipation, 2013) ele não só inaugural seu texto mencionando a importância da obra de Arendt - ao lado de autores como Le Guillant e Tosquelles, que veremos mais adiante - como retoma seu paradigmático comentário sobre o labor. Após comentar sobre a oposição freudiana entre labor e opus (obra), vai justamente citar o comentário de Arendt e retomar as categorias aristotélicas, em especial as de "ação ética" (praxis) e o trabalho (poiésis). (Dejours, 2013. P. 11 - 15)

${ }^{10} \mathrm{O}$ uso do termo 'hipermoderno' e suas variações não é casual, e será explorado em maior profundidade adiante; como introdução, este termo surgiu em 2003 em um colóquio da École Superieure de Commerce de Paris e do Laboratório de Mudança Social da Universidade Paris 7 consagrado ao Indivíduo Hipermoderno. Esse evento foi preparado pelos pesquisadores Nicole Aubert, François Ascher, Claudine Haroche, Vincent de Gaulejac e Elisabeth Tissier-Desbordes, e diversos artigos originados dessas discussões foram publicados no ano seguinte, em um volume do mesmo nome (Aubert, 2004. P.7). No ano seguinte, o filósofo Gilles Lipovetsky entrevistado pelo também filósofo Sébastien Charles, também publicou uma obra chamada 'Tempos Hipermodernos' (Lipovetsky, 2005). Um ano antes desse termo ser usado, em 2003, o filósofo Dany-Robert Dufour lançou seu polêmico 'A Arte de Encolher Cabeças' (L'Art de Réduire les Têtes, 2003), que também trazia ideias bastante alinhadas com os demais citados, embora ainda adotando o termo 'pós modernidade'. Esses são apenas alguns exemplos de como este termo e os conceitos a ele ligados se consagraram, mas iremos explorar suas implicações no campo das relações de trabalho posteriormente. Para resumir, o que este significante carrega, no já mencionado livro 'O Indivíduo Hipermoderno', Nicole Aubert abre com um histórico do encontro que lançou essas discussões, e o prefácio faz uma síntese de sua leitura para esse significante: "Tratava-se e analisar de que forma um certo número de desdobramentos induzidos pelas mutações econômicas, tecnológicas, sociais e culturais da segunda metade do século XX têm contribuído para redesenhar os contornos da identidade contemporânea." (Aubert, 2004. P.8).
} 
quebra dos laços de solidariedade e põe em questão a própria relação entre sociedade e mercado ${ }^{11}$.

Vale uma digressão em relação tanto à centralidade do trabalho como da mudança de seu estatuto no tecido social. A socióloga francesa Danièle Linhart aponta como anteriormente na narrativa humana, o trabalho tinha um caráter muito diverso do que observamos na 'sociedade laboral'.

Essa valorização e centralidade do trabalho não são uma lei universal e atemporal: é necessário lembrá-lo? Sob o Antigo Regime "o trabalho com conotações cristãs tradicionais de dor, de fardo e penitência (...) No schema do pensamento cristão, o trabalho é uma marca de vilania, a prova e punição do pecado original. Não se trata de uma atividade enobrecedora, mas o símbolo da queda da humanidade abjeta diante de Deus". Diferente da arte, "o trabalho em si, sem arte para conferi-lo as regras para se infundir da razão, era uma cicatriz da nulidade social e moral.

(Linhart, 2009. P. 17, trad. livre)

Essa passagem do trabalho como fardo e o trabalho como medida de valor foi promovida em consonância com a Revolução Industrial; os novos modos de produção geraram novas dinâmicas sociais, em especial e suas consequências nas relações econômicas e o acesso ao consumo. Um dos principais autores que articulam esta ligação entre a economia de consumo e as transformações sociais da contemporaneidade é Dany-Robert Dufour. Em seu "A Arte de Encolher Cabeças" (2008), Dufour marca que o que caracteriza a contemporaneidade seria a destituição do "duplo sujeito da modernidade", um sujeito crítico (Kantiano) e neurótico (Freudiano), que traria o surgimento do sujeito pós-moderno. (Dufour, 08. P. 2) O indivíduo acrítico, com uma identidade flexível e sem a compulsão neurótica à repetição seria, assim, a melhor fonte receptora de commodities. (Dufour, 08. P. 10-11) "Hoje, necessitamos de um sujeito precário, acrítico, que mostre 'tendências psicóticas'. Eu refiro a um sujeito que está aberto a todo tipo de identidades flutuantes e que, desta forma, está pronto a ser plugado a toda commodity. O cerne do sujeito [le vif du sujet] está sendo

\footnotetext{
${ }^{11}$ Uma entrevista publicada no jornal A Folha de São Paulo de 04 de Fevereiro de 2016 com o economista Nouriel Roubini intitulada "O que exatamente torna anormal a economia mundial?" reforça esta hipótese. Sua proposta central é que o descolamento entre mercado financeiro e os riscos político-sociais em busca de lucros inéditos causa uma situação de imensa instabilidade permanente e amplifica problemas sérios como a crise europeia e conflitos armados geopolíticos.
} 
substituído pelo sujeito vazio [le vide du sujet], aberto aos quatro ventos". (Dufour, 08. P. 12, trad. livre) Dufour ainda acrescenta: as forças que agenciam o capitalismo contemporâneo agem para lançar o sujeito a um "mundo sem limites", o que segundo Lebrun encorajaria a ação desmedida (acting out) e comportamentos borderline. (Dufour, 08. P. 12, trad. livre)

Trata-se de um cenário potencialmente tóxico para a grande maioria dos trabalhadores, inconscientes das questões socioculturais que promovem sofrimento, buscam ajuda nas mais diversas práticas. Em seu texto "Sublimation et Vie Économique" (Sublimação e Vida Econômica, de 2012), Nelson da Silva Jr. analisa os efeitos destas transformações na própria relação pulsional: "A natureza desta influência \{da tecnologia psíquica de persuasão no mundo do trabalho\} é feita na forma de um radical controle da vida pulsional e social; esta nova organização econômica implica por sua vez exigências sublimatórias ao psiquismo de uma natureza e intensidade inéditas." (Silva Jr. 2012, P. 438, tradução livre) Silva Jr. nos esclarece que justamente dois campos são especialmente afetados por estas transformações: o consumo e o trabalho. "A partir das concepções freudianas sobre a sublimação veremos que estas exigências são de natureza fundamentalmente patogênica, e que seus efeitos justificam a retomada psicanalítica de uma doença própria da cultura econômica". (Silva Jr. 2012, P. 438, tradução livre) Segundo este mesmo autor é possível traçar a origem histórica destas transformações na economia de consumo e no nascimento das práticas de recursos humanos (Silva Jr. 2012. P. 442)

Para balancear esta perspectiva, é importante recorrer ao trabalho de autores como Gilles Lipovetsky. Segundo seu colaborador Pierre-Henri Travollot, desde a 'Era do Vazio' (L'Ėre du Vide), de 1983, Lipovetsky lançou os parâmetros para o que na França seria amplamente conhecido como o 'paradigma individualista'. Seus próximos trabalhos exploraram "em detalhes as múltiplas facetas do indivíduo contemporâneo: o reino sem precedentes da moda, a metamorfose da ética, assim como as novas relações entre os sexos, a explosão da luxúria e as mudanças na sociedade de consumo". (Lipovetsky, 2005. vi) 
Mais uma vez, como ressalva Sébastien Charles em sua introdução, não se trata de afirmar o fim dos tempos, ou mostrar a degradação da época atual em favor das anteriores. "Se olharmos no longo prazo, condenar o presente provavelmente foi a atividade crítica mais corriqueira usufruída pelos escritores, filósofos e poetas desde o início dos tempos. Desde então, Platão se preocupava com a perda de valores e a emergência de uma Era do Ferro". (Lipovetsky, 2005. P.1)

Mesmo feita esta ressalva, ainda nos deparamos frequentemente com a perspectiva do mal-estar - frequentemente nomeado como 'sofrimento' na esfera do trabalho. Neste sentido, a produção de pesquisadores como Dejours, Doray, Silva Jr. e outros autores nos mostram quão prolífico é este campo de interface entre psicanálise e psicologia organizacional; é inegável a contribuição da teoria clínica psicanalítica à psicopatologia do trabalho, assim como sua potência como elemento de apoio em um mundo do trabalho com expectativas infladas de sucesso, riqueza e mesmo o próprio mito da felicidade associada ao trabalho.

No entanto, é essencial marcar com cuidado o uso deste significante: sofrimento. Assim como Lipovetsky e Serroy, nos parece mais adequado retornar ao termo freudiano clássico: "Mercado, tecnociência, indivíduo: entregues apenas a si mesmos, esses princípios organizadores dominantes fizeram nascer uma culturamundo sem precedentes na história, geradora de um novo "mal estar na civilização", de uma nova relação cultural com o mundo" (Lipovetsky, Serroy, 2011. P. 32) Afinal, por que não pensar nestas mesmas linhas sobre novas formas de relação com o trabalho? 
TRABALHO = EMANCIPAÇÃO / MAL ESTAR: A CONDIÇÃO HUMANA

Em sua obra "A Condição Humana", Hannah Arendt (1998) se dispõe a analisar o fenômeno do trabalho e realiza um estudo amplo no qual diferencia o que nomeia como 'vita activa', 'labor' e 'trabalho'. Inicia sua pesquisa com uma reflexão sobre duas definições distintas do trabalho, Labor e Trabalho. O Trabalho seria aquela tarefa que tem um significado em si, promove um senso de identidade e realização e tem um começo e um fim. O Labor é algo muito mais associado a uma tarefa alienada, interminável, na qual o sujeito se exaure sem fruir daquilo que ele mesmo produz. Trabalho seria aquilo que dialoga com o ato criativo, com o brincar, com uma realização. O Labor seria o fazer movido puramente pela necessidade, uma herança da luta do homem contra a natureza. Em uma sociedade 'laboral', o trabalhar perde o sentido e toda capacidade de realização; aquilo que seria uma possível via de satisfação e sublimação da situação humana se converte, por esse esvaziamento do sentido, em uma tarefa geradora de sofrimento e alienação. Podemos mesmo pensar que se existe uma condição humana na sociedade contemporânea, seria a de trabalhar ou adoecer. $^{12}$

Uma diferença essencial entre o trabalho e labor, para a autora, estaria nos campos da liberdade e da possibilidade de escolhas mais livres, ou menos

\footnotetext{
12 Dejours apresenta uma outra perspectiva interessante ligada ao sofrimento em um texto de 1986, publicado em 2016 no livro 'Situações do Trabalho' (Situations de Travail): "Em psicopatologia do trabalho, temos posto em evidência duas linhas fundamentais de sofrimento, respectivamente em relação com o medo e com o tédio. Uma Terceira linha está em processo de exploração: aquela ligada às "relações de trabalho. (...) Enfim, uma quarta linha poderia tomar lugar no estudo do sofrimento em relação com "a economia do corpo"." (Dejours, 16. P. 40) Não obstante, exibiu em seu trabalho uma perspectiva bastante contrária à visão de Arendt sobre o tema, ao menos em seu relato em "La Panne" (2012). "Hannah Arendt efetivamente não via nenhuma dignidade no trabalho. (...) Ela concebia essa atividade do corpo que é o trabalho fora do político, o reduzia a uma questão social sem maior valor, o político se fundando ao contrário, sobre o desejo de se emancipar das necessidades da vida. Para fazê-lo, ela distingue o trabalho como atividade ou labor, que corresponde à manutenção, animal, da vida e que repousa sobre o apagamento de toda consciência individual; a obra que fornece ao mundo artificial dos objetos, nos quais habitam as existências individuais; por fim, a ação, a única atividade que se localiza diretamente em relação aos homens, a única a corresponder à condição humana da pluralidade, ao mundo político. (...) é por esse antagonismo absoluto entre uma esfera social e a vida política, somente digna a uma humanidade livre, que o trabalho se encontra repudiado." (Dejours, Bouniol, 2012. P. 91 - 92. Trad. livre)
} 
determinadas pelas necessidades do corpo. Haveria naturalmente confusões e uma evolução do conceito de Labor, que finalmente nos traria para muito perto de considerar as sociedades em sua maioria como sociedades laborais.

Baseado na reflexão de Arendt, efetivamente nos parece que o trabalho realizado pela maioria dos sujeitos da contemporaneidade está em sua grande maioria muito mais associado a Labor do que efetivamente Trabalho. Não é sem razão, observa a autora, que o projeto marxista não era apenas eliminar a luta entre classes, mas muito mais que isso; seu ideal utópico seria o de libertar o homem do trabalho.

O risco de que a era moderna da emancipação do trabalho não só falhasse em abrir uma era de liberdade para todos mas, ao contrario, resultasse em forçar toda a humanidade pela primeira vez ao peso da necessidade já era percebido por Marx quando ele insistiu que a meta da revolução não poderia ser de todo a já alcançada emancipação das classes trabalhadoras, mas sim a emancipação do homem do trabalho.

(Arendt, 1998. P. 130-131)

Como já mencionado anteriormente, à exceção de uma minoria emancipada das necessidades ligadas ao consumo - geralmente as classes dominantes e economicamente privilegiadas - a grande maioria das pessoas estaria inscrita neste modelo no qual o trabalho não seria nem determinado por escolhas livres e muito menos uma opção, e sim mais uma necessidade resultante das necessidades do corpo. "Ainda assim, os desenvolvimentos da última década e especialmente as possibilidades que se abriram através do desenvolvimento amplo da automação, nos deram razões para considerar se a Utopia de ontem não se tornaria a realidade de amanhã, de forma que eventualmente só o esforço do consumo restará como 'a dureza e confusão inerente ao ciclo biológico no qual o motor da vida humana restará presa'”. (Arendt, 1998. P. 130-131)

Trabalhar pode ter sido visto desde o início da produção humana como um sacrifício, renúncia aos instintos que conduzem à experiência do prazer e fruição. Mas o trabalho, no formato que vemos atualmente, é um efeito diretamente ligado à Revolução Industrial do Século XIX; quando cruzamos a fala de Hannah Arendt com os dados que temos da época Vitoriana, nos parece efetivamente que a 
Humanidade partiu de um momento histórico de relativamente pouco trabalho para uma aceleração repentina que, de certa forma, dura até os dias de hoje. Segundo Arendt, "Durante a Idade Média estima-se que uma pessoa não trabalhava mais que metade dos dias do ano. Os feriados oficiais somavam 141 dias (...). A extensão monstruosa do dia de trabalho é uma característica do início da Revolução Industrial, quando os trabalhadores tinham que competir com as recém introduzidas máquinas. Antes disso, a extensão de um dia de trabalho somava onze ou doze horas na Inglaterra do Século XV e dez horas no XVII. (...). Em resumo, 'os trabalhadores conheceram durante a primeira metade do século XIX condições de existência piores que aquelas nas quais viviam os menos afortunados'." (Arendt, 1998. P 132-133)

Para Dejours (2007), definir trabalho talvez implique em diferenciá-lo de uma dimensão mais utilitária de um 'meio de vida' ou de sustento, aquilo com o qual o homem extrai da natureza o que necessita para sobrevida. Este segundo grupo seria algo muito semelhante ao que Hannah Arendt definiu como Labor em sua "A Condição Humana". O homem trabalha movido por uma intenção, e 'trabalhar nunca se trata exclusivamente de produzir, mas de transformar a si' (Dejours, 2007. P. 22). Além da finalidade, subsistência, lucro ou deixar uma marca de si na Terra, o homem tem algo que o diferencia do animal; trata-se do único animal que idealiza o que irá realizar antes de realizá-lo. Trabalhar significa produzir algo, transformar algo com uma intenção, e esse algo de certa forma se relaciona com outros 'algos', mesmo que essa atividade seja determinada por um supervisor ou pelo mercado.

É conhecida a ideia de que o psicanalista Sigmund Freud afirmou que a chave para a realização seria a habilidade para 'amar e trabalhar'13. Assim como a possibilidade de satisfação sexual ou amorosa, o autor acreditava fortemente no papel do trabalho como uma força que nos adere à realidade e permite uma convivência social positiva (Freud, S. 1930/2010. P. 36), sem contar na

\footnotetext{
${ }^{13} \mathrm{Um}$ texto - entre muitos - que reforçam a presença do tema do trabalho na obra freudiana é o de Nathan Hale, presente no livro "Themes of Work and Love in Adulthood" (In. Smelser, Eriksson, 1980 P. 30, 32-38)
} 
sublimação dos instintos pulsionais pelo prazer promovido pelo exercício intelectual. Esta ideia já foi ressaltada pelo trabalho de Christophe Dejours; em seu texto "Trabalho vivo" (Volume I: Sexualidade e Trabalho), de 2009, em sua tese que o trabalho assume na vida adulta um peso tão grande ou talvez maior que o da sexualidade. (Dejours, 2009. P. 177)

Embora concordemos com o papel do trabalho na maturação ou patogênese da psique contemporânea, também se faz necessário perceber o quanto este tema mobilizou oportunidades outras de intervenção, desde o próprio nascimento dos grupos de recursos humanos até outros discursos como as terapias ligadas ao trabalho em grupo ou individuais e variações do discurso terapêutico como o Coaching. Seja movido pela fertilidade deste novo mercado ou influenciado por culturas mais adaptadas a este discurso que a outras formas de intervenção na relação homem-trabalho (ou homem - desejo!), novas áreas de intervenção como

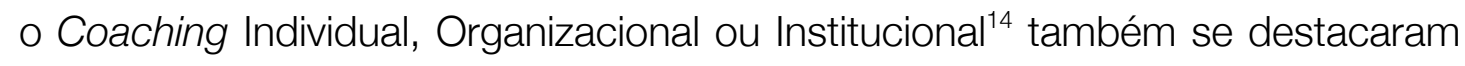
para intervir em temas ligados às queixas atribuídas à relação dos empregados com o trabalho. Seja pelo incômodo frente às escolhas realizadas, nas relações entre subordinados e superiores, queixas legais associadas à prática de violência física ou psicológica, houve um perceptível aumento de solicitações de ajuda em temas relativos a trabalho. Na contemporaneidade - ou podemos até trazer o tema da hipermodernidade ${ }^{15}$, da Sociologia Clínica francesa (Aubert, 2004) - o

\footnotetext{
${ }^{14}$ Para uma diferenciação bastante simplista, poderíamos postular que a diferença entre essas modalidades seria a seguinte: no Coaching Individual, o sujeito financia o processo e seu contrato, expectativas e demanda são estabelecidos exclusivamente entre o participante e o profissional. No Coaching Organizacional, a demanda é contratada e contratada por uma organização, mas o participante tem autonomia para determinar os objetivos de mudança. O processo é supervisionado, mas a organização não teria controle direto sobre o processo, somente recebendo informações gerais do andamento do processo. O Coaching Institucional leva essa relação ainda mais longe; é a organização que atua como o 'cliente principal' do processo, determinando objetivos e definindo as mudanças que devem ocorrer (por exemplo, melhora do desempenho como líder, melhor comunicação, ou desenvolvimento de habilidades específicas ligadas à função). Geralmente esses processos ocorrem ligadas a um projeto específico de desenvolvimento executivo ou, na maioria dos casos, em situações nas quais se espera uma mudança específica de comportamento sem a qual o participante poderia ser desligado caso não seja capaz ou não deseje a mudança.

15 Utilizamos o termo hipermodernidade baseado no trabalho organizado por Nicole Aubert (2004). Nesta obra, autores como Nicole Aubert, Robert Castel e outros utilizam esse termo para descrever o momento contemporâneo, que seria uma exacerbação dos atributos de excesso e busca de experiências sensoriais extremas da modernidade. Não se trataria de uma ruptura, mas um destempero em função do exagero dos atributos dos anos 1970 a 90 que conduzem, entre outros pontos, a uma ascensão do individualismo.
} 
trabalho, que pode ser um espaço potencial de realização ou emancipação do sujeito, passa para alguns a ocupar um papel de desconforto ou aflição. Seja pela dificuldade de fazer escolhas - que sempre levam a novas escolhas - seja pela insatisfação pela atividade em si, pela falta de reconhecimento dos superiores ou pares, o trabalho parece ter alcançado para muitos indivíduos um espaço privilegiado na vida psíquica.

Antes de avançarmos, vale um olhar mais detalhado sobre o conceito da hipermodernidade, ou do 'indivíduo hipermoderno', nos termos da obra organizada por Nicole Aubert em 2004. Esta autora afirma que mesmo que seu debate tenha ganhado maior tração na década de 2000 (ao menos na França), esse termo em si teria surgido anos antes, derivados das pesquisas de Max Pagès em seus estudos sobre uma célebre multinacional norte americana (Aubert, 2004. P. 15). Em contraste com a empresa moderna, a empresa "hipermoderna" seria aquela que utiliza técnicas gerenciais desenvolvidas para exercer uma profunda influência psicológica em seus empregados. "Tratava-se então de estudar as correspondências entre as formulações técnicoeconômicas, as estruturas políticas do poder que se estabeleciam por trás dessas transformações, e as mudanças que induziam na psicologia inconsciente coletiva." (Aubert, 2004. P. 15)

Seria nesta direção que o "pós" não caberia; trata-se de um "super", ou "hiper", no sentido que não traria uma superação, mas uma exacerbação dos valores ou desafios - do moderno. Trata-se, efetivamente, de uma marca de um excesso que, como afirma posteriormente Lipovetsky, traria tanto uma ampliação de certos traços da autonomia e individualismo, como uma fragilização do eu, alienação e enfraquecimento do tecido das relações sociais. Neste ponto, ecoam também ideias de Richard Sennet e Hannah Arendt: as transformações sociais e culturais da segunda metade do Século $X X$ ampliaram o poder e a influência do indivíduo sobre o social, mas, ao questionar toda e qualquer instituição e os valores tradicionais, inauguraram um indivíduo pouco integrado à sociedade, ou o que Sennet alertaria como a ascensão de uma "Tirania das Minorias". 
Tanto Nicole Aubert como Lipovetsky evitam a melancolia ou a comemoração deste novo modelo, mas marcam essencialmente sua natureza ambígua: ao romper com os limites do social e das regras, o indivíduo alcança uma possibilidade inédita em termos da satisfação de seus impulsos, ao sacrifício de poder perceber-se como parte de um todo que confere algum senso mais estável de identidade. Assim como Dufour, ambos autores marcam como central a medida do indivíduo como um 'consumidor ideal', ávido por sacrificar a crítica neurótica ou mesmo a dúvida em favor de uma satisfação temporária ou instantânea, tornando o sujeito condenado a responsabilizar-se por seu destino e, simultaneamente, aberto ao maior número possível de commodities disponíveis. "Neste contexto no qual a adesão se faz muito mais a si mesmo que à uma causa, na qual o indivíduo transformado antes de mais nada em um consumidor deve sobretudo lutar por sua existência social, assistimos a uma recomposição da identidade pessoal, ao mesmo tempo fragilizada e reforçada, na renovação de perfis psicológicos, no surgimento de novos tipos de patologias, a uma hipercompetitividade permanente e uma relação com o tempo jamais vista." (Aubert, 2004. P. 16-17) Essas ideias aparecem de forma bastante semelhante na introdução de S. Charles ao livro de Lipovetsky: "a própria lógica do individualismo e a desintegração das estruturas tradicionais de normatização (...) produzem fenômenos tão diferentes entre si como o autocontrole e apatia individual, hiperatividade Prometeica e total falta de caráter [willpower]". (Lipovetsky, 2005. P. 7, trad. livre) Para este último autor, não faltam exemplos para caracterizar um paradoxo, como uma sociedade obcecada com a saúde corporal e controle de peso e uma sobreoferta de alimentos fast food em paralelo a uma epidemia de obesidade, indivíduos anoréticos, bulímicos e uma desestruturação programada de nossos hábitos alimentares regulares. "É essencial notar que cada aumento em autonomia ocorre às custas de uma nova dependência, e o hedonismo pós-moderno teria assim duas faces: é desestruturante e irresponsável para um certo número de indivíduos e prudente e responsável para a maioria”. (Lipovetsky, 2005. P. 8) 
Se formos traçar elementos em comum que caracterizem o hipermoderno segundo os autores já citados, temos em comum não só a cronologia - segunda metade do Século XX - mas também elementos como economia, tecnologia, contrastes sociais entre os "em excesso" e os "em falta", mas, especialmente, o elemento da sociedade do consumo. Aparentemente, nenhuma força foi tão transformadora na virada do Século como a aceleração e as mutações das formas e influência do consumo. Se olharmos outros autores, inclusive, podemos perceber que mesmo no conceito da "moda" para Lipovetsky como na influência dos 'magazines' na aceleração da Revolução Industrial em suas diversas encarnações, a soma destas forças toma um papel central nas formas de subjetivação da hipermodernidade.

No entanto, a dimensão crítica do trabalho de Lipovetsky é cautelosa em não demonizar ou glorificar as transformações promovidas pela ascensão da sociedade de consumo; a visão do autor é manter-se de maneira equilibrada e perceber o fenômeno tanto em seus aspectos debilitantes como emancipatórios. "Identificar o consumismo instituído [consummate fashion] com um processo sem precedentes de homogeneização e despersonalização é tomar um ponto de vista superficial; em realidade, o consumismo é a força motriz de questionamentos subjacentes mais insistentes, uma multiplicação de pontos de vista subjetivos, uma queda na similaridade de visões pessoais menores. As grandes certezas ideológicas estão abrindo caminho para singularidades subjetivas que podem não ser tão originais, criativas ou reflexivas, mas são muito mais múltiplas e flexíveis que nunca". (Lipovetsky, 2005. P. 15-16) Desta forma, o autor marca que embora haja um enfraquecimento de 'garantidores simbólicos' como a família ou religião (para usar um termo de Dufour), há um elemento positivo na mudança que permite a expressão de liberdades individuais historicamente inéditas, como a participação sócio política de mulheres, direitos de minorias, emancipação de imposições religiosas ou ideológicas. Trata-se sem dúvida de um terreno arriscado e ainda em construção, mas que não pode ser simplesmente caracterizado como uma perda ou redução da capacidade humana de pensar e construir sua realidade. 
No entanto, para nossa pesquisa e, especialmente, mapear o campo do mal estar no trabalho, há implicações arriscadas a serem pensadas. Uma delas, por exemplo, será um efeito específico promovido pela efemeridade e instantaneidade fomentada por uma sociedade orientada ao consumo: a substituição dos ideais de transcendência pelo paradigma de "propósitos" consumíveis e transitórios. Isso traria hipóteses para pensarmos, entre outras coisas, nesta busca citada por Hannah Arendt (2008) por um propósito associado à atividade profissional. Podemos pensar na mudança essencial que se deu pós 1950, na qual pela primeira vez na história humana o indivíduo passa a atribuir a sua atividade laboral não apenas a base de sua subsistência, poder ou segurança, mas também buscar nesta um 'propósito' ou sentido que, ate então, seria reservado ao transcendente ou ao campo do religioso.

São reflexões que vão exigir um exame muito mais preciso, mas antes de ingressar nesta discussão é essencial entender na perspectiva sócio técnica como o tema da relação homem-trabalho ganhou tamanha relevância. Nas lentes da História da Administração, podemos pensar nos originadores da reflexão sobre a importância da relação do homem com o seu trabalho, e traçar hipóteses que colocariam em contexto algumas transformações importantes no mundo do trabalho. Para isso, é marcante a relevância e gênese do conceito de Fábrica.

Seguindo o trabalho de Albert Cherns, (1982), esse rumo pode ser traçado de maneira sumária desde o período chamado Revolução Industrial. A partir de 1718, com o nascimento do 'Factory System' na Inglaterra pós Renascimento, podem ser vistos sinais do que se tornaria um dos modelos de trabalho na contemporaneidade. Estimulada por uma estabilidade maior nas guerras contra franceses e dinamarqueses que assolaram o país por séculos, a economia inglesa se beneficiava da relação com as colônias. Com uma recém-nascida demanda crescente de matérias primas, os pioneiros da indústria aprovaram a concepção do que se tornaria a ancestral da Fábrica: ao reunir artesãos sob um mesmo espaço, a produção pôde finalmente assumir uma escala que superou as dificuldades logísticas e se concentrou em melhoria do rendimento e ganho. Os trabalhadores que antes tinham autonomia total de trabalho tiveram que se 
adaptar a um 'supervisor', a produzir em um ambiente estranho e demandas de desempenho crescente. O artesão passava a ter uma renda relativamente garantida, que provia uma estabilidade nova, mas estava sujeito a um acordo que o submetia a um modo muito específico e alheio a seu próprio estilo de produzir e viver.

Por volta de 1756, com a criação das primeiras máquinas a vapor, essa organização ganha novas potencialidades e outros desafios. Quando a demanda crescente do mercado por bens produzidos em escala somou-se à relativa ausência do que chamamos hoje de leis trabalhistas, emergiu um contexto no qual os trabalhadores foram levados a condições críticas de exaustão. Citando David Cody (2013) da Hartwick College, na Era Vitoriana qualquer pessoa de mais baixa renda e com mais de 4 anos era forçada a trabalhar. Como aprendiz na construção civil, os trabalhadores faziam jornadas de 64 horas por semana no verão e 52 no inverno. Já os serventes gerais, que somavam mais de 120.000 na Londres no meio do século, trabalhavam 80 horas por semana por um halfpence a hora. A grande maioria das crianças trabalhava 16 horas por dia sob condições atrozes - a mesma carga de trabalho dos idosos. Nas minas de carvão e ferro, as crianças (meninos e meninas) começavam a trabalhar com 5 anos e em média morriam antes de completar 25 anos. Outras indústrias tinham jornadas ainda mais longas, como indústrias de gás, estaleiros, fábricas de fósforos, pregos e limpeza de chaminés (consideradas um emblema para a 'destruição dos inocentes'). Esse cenário só se transformou gradualmente com a evolução das máquinas a vapor para as máquinas movidas pelo motor diesel, que exigiam trabalhadores mais especializados para operá-las; os demais proletários continuavam em regimes desumanos, e sem praticamente nenhum direito trabalhista. Como afirma Sigmar Malvezzi, (1999) ${ }^{16 .}$

A transição das fábricas ativadas pela máquina a vapor para as fábricas movidas pelo motor a óleo diesel caracteriza a era da tecnologia eletromecânica. As dificuldades dessa transição advinham da velocidade mais alta, da sofisticação da tecnologia e da diferenciação ocupacional. As fábricas necessitavam do desempenho mais regularizado e constante por parte dos

\footnotetext{
${ }^{16}$ Sobre essa análise histórica da evolução e especialmente da dureza do mundo do trabalho no século XIX, conferir Dejours (2000). Parte de sua introdução traz uma análise essencial chamada 'O Século XIX e a luta pela sobrevivência". (P. 42 - 47)
} 
trabalhadores daí a necessidade de rearticulação do processo de produção de uma forma que permitisse mais controle sobre sua eficácia. (...) Os relatos e pesquisas dessa época sugerem que a alocação dos trabalhadores em diferentes tarefas e a fadiga, constituíam os dois problemas merecedores de particular atenção por parte dos gestores das fábricas (Cherns, 1982). Os trabalhadores não revelavam igual a competência e interesse pelas distintas tarefas. Estas, por sua vez, cresciam em diferenciação dentro de distintos campos, como produção, manutenção e embalagem, evidenciando exigências de cuidados e habilidades diferentes. Além disso, a forte pressão pelo aumento da produção, esticava as jornadas de trabalho por até 14 horas diárias, sem o descanso semanal, um fato comum, tal como ocorre nas empresas de hoje. Os direitos trabalhistas não eram reconhecidos e regulamentados, como hoje, o trabalho era penoso e as condições de vida ainda piores. Acidentes, fadiga, ameaça da tuberculose, resistência ao ritmo impiedoso das máquinas e o fardo de cronogramas apertados, frequentemente comprometiam o desempenho dos trabalhadores, reduzindo a velocidade prevista para o fluxo de produção. A organização das tarefas ainda era pouco racionalizada e os gestores não se sensibilizavam pelos problemas humanos do trabalho. A qualidade de vida no trabalho era visivelmente desumana e ao mesmo tempo que a necessidade de trabalhadores especializados, crescia a olhos vistos.

(Malvezzi, 1999)

Foi por volta de 1880 que começou a haver de forma mais consistente uma diferenciação que refletiria em mudanças nas estruturas ocupacionais. Estima-se que cerca de $92 \%$ da mão de obra era pouco especializada, ou seja, os custos e problemas associados à má utilização do maquinário eram uma questão séria central. Se anteriormente o custo de reposição de um profissional era muito baixo ou mesmo nulo, neste momento era preciso investir em uma seleção mais cuidadosa de pessoas que, por sua vez, exigiriam mais recursos para serem treinadas. A necessidade de uma seleção mais precisa fez surgirem as ciências da quantificação dos desempenhos, como a Psicometria. Trata-se de uma mudança significativa na forma de pensamento, que inaugura o início de uma 'quantificação das emoções'; se o trabalhador em 1800 teve de abrir mão de sua autonomia e conviver em um espaço controlado, perto de 1900 ele passa por outra concessão que seria o mapeamento e quantificação de suas habilidades e emoções.

Novamente a Europa foi assolada por Guerras, e a indústria teve de se adaptar à perda de parte significativa da mão de obra, escassez de matéria-prima e 
imposição de produção pelos governos (motores para aviões, equipamento para soldados, etc.). Aliado ao avanço tecnológico que a Guerra estimulou, surgiram desafios associados à necessidade de um cuidado maior na relação de trabalho; se em 1880 a massa de trabalhadores era rudimentar e pouco formada, por volta de 1920 estima-se que mais de um terço da mão de obra era especializada. Com custos maiores de retenção, recompensas e a formalização de alguns contratos de trabalho, faz-se necessário dar atenção a qualidades como comunicação, influência e especialmente uma relação mais harmônica entre homem e tecnologia. Perto de 1940, já se iniciava a introdução de ferramentas e tecnologias mais complexas nas fábricas. Em paralelo, outras transformações socioculturais se impunham; segundo Eva Illouz (2007), os ambientes de trabalho tornavam-se cada vez mais emocionais com a introdução do que chama 'discurso terapêutico' nas organizações. O papel dos supervisores foi gradualmente se 'feminizando'; além de características como assertividade e voz de comando foram gradualmente exigidos empatia, reconhecimento e controle emocional.

Ao introduzir o elemento do reconhecimento, cabe um caveat interessante; segundo Axel Honneth - possivelmente o autor mais celebrado no tema do reconhecimento e herdeiro da Escola de Frankfurt - os estudos sobre este tema foram trazidos à tona na modernidade não pelo trabalho de Hegel sobre o assunto, mas sobre a preocupação com o trabalho. Segundo o autor, "No início [das pesquisas sociológicas orientadas pelo procedimentalismo], foi a pesquisa histórica sobre o movimento trabalhista que inaugurou a amplitude pela qual os anseios de reconhecimento já haviam marcado os protestos sociais das classes inferiores na ascensão, e gradual conquista, capitalista. Mirando na tendência de considerar somente interesses econômicos, historiadores como E. P. Thompson e Barrington Moore foram capazes de mostrar que quando se tratava da origem motivacional das fontes de resistência e protesto, a experiência de violação de queixas locais ligadas à honra era muito mais importante. Surpreendente próxima a esta linha de pesquisa, um amplo campo de pesquisa logo se abriu na Sociologia, que buscava a questão do que os membros de classes sociais inferiores viam como o cerne de suas experiências e opressão e injustiça". 
(Fraser, 2003. P. 131, Trad. livre) Desta forma, como veremos adiante no trabalho de Eric Hobsbawm a questão do reconhecimento nasceu do senso de honra ou orgulho - e sua importância para a pesquisa sociológica será significativa.

Seguindo pela via da Sociologia, mudanças importantes aconteceram no mundo do trabalho ao longo do século 20. A socióloga Eva Illouz nos aponta algumas mudanças essenciais: a invasão do discurso terapêutico nas organizações privadas (e no ambiente de trabalho), a dissolução da separação entre vida privada e vida pública, a "feminização" dos papeis de comando, entre outras. (lllouz, 2007).

Após o surgimento dos grandes magazines com maior poder de barganha é necessária uma velocidade maior de introdução de novos produtos e o mercado ganha uma competitividade mais agressiva. Essas mudanças fizeram com que as organizações tivessem de atuar de forma de atuar mais adaptada a constantes mudanças e operar em níveis maiores de complexidade e incerteza. A transição para uma economia livre exigiu que as organizações passassem a funcionar como sistemas abertos e atuar mais fortemente na engenharia das contingências: controlar uma ou duas variáveis como 'cliente' e 'fornecedor' não seria mais o suficiente. Toda a cadeia de valor deveria ser controlada: vendas, mídia, marca, sociedade. Do sistema fechado de galpões, trabalhadores, supervisores e clientes, passamos a um modelo no qual esse universo é constantemente revisto, sofre interferências do mercado e da tecnologia, clientes e forças geopolíticas.

Por volta de 1950, o aparecimento de novas e mais avançadas tecnologias mudou mais uma vez o panorama das organizações. A evolução do processamento de informações provocado pelo computador e seus precursores propiciou novas ondas de revisão da organização e das tarefas. Com a ampliação do acesso da sociedade a meios de comunicação de massa, novas demandas surgiram e vêm surgindo; entre essas, a insatisfação crescente das pessoas com suas próprias condições de trabalho, tema de nossa pesquisa. Conforme já mencionamos, o trabalho de Dufour sobre este tema é preciso ao mapear estas transições e, em especial, seus efeitos na subjetividade contemporânea. Sujeitos atormentados por uma necessidade insaciável de suprir todo e qualquer tipo de desejo correspondem ao melhor encaixe possível aos produtos que são criados 
e tornados obsoletos em uma velocidade cada vez maior. Como isso pode refletir nas relações de trabalho? Uma das ideias que Dufour apresenta é do impacto da destituição do sujeito 'kantiano'; "Segundo Kant, nem tudo tem valor monetário: 'algo têm preço, ou têm dignidade. O que quer que tenha um preço, pode ser substituído por algo equivalente. Em contraste, aquilo que é exaltado acima de qualquer preço e, desta forma, não admite um equivalente, teria dignidade'. Não poderíamos deixa-lo mais claro: dignidade é insubstituível, 'impagável', e não tem equivalente'." (Dufour, 08. P. 10, Trad. livre) Assim, se consideramos que as organizações com fins lucrativos trabalham para e pelo capital - ou, como costumam dizer, para 'gerar valor aos acionistas' - os trabalhadores são ativos não fixos. A partir da lógica que devem ser gerenciados não apenas por suas qualidades subjetivas, mas especialmente por sua capacidade de gerar valor, estamos no domínio da gestão de custos da Administração; nenhum indivíduo é insubstituível e, desta forma, torna-se impossível responsabilizar qualquer organização por zelar pela dignidade do sujeito.

O autor Richard Sennet tem uma produção vasta sobre o tema, mas há uma passagem que sintetiza esta transição importante de nossa sociedade e que inaugura, entre outros, o conceito de 'carreira' e seu impacto no significado mesmo do trabalho na formação da subjetividade contemporânea.

\begin{abstract}
Esta ênfase em flexibilidade [trazida pelo 'capitalismo flexível' contemporâneo] está alterando o próprio significado do trabalho, assim como das palavras que usamos para ele. "Carreira", por exemplo, em sua origem no Inglês significava uma estrada para carruagens, e eventualmente foi aplicado ao trabalho [labor], significando um canal para a vida toda que orienta a busca econômica de uma pessoa. O capitalismo flexível bloqueou a estrada reta da carreira, subitamente divergindo empregados de um tipo de trabalho a outro. No Inglês do Século XIV, a palavra 'trabalho' [job] em Inglês significava um toco, ou um pedaço de algo que pudesse ser carregado de um lugar a outro. A flexibilidade atual trouxe de volta esse significado arcaico de 'job', pois as pessoas fazem 'tocos de labor' [lumps of labor], pedaços de trabalho ao longo do curso de toda uma vida.
\end{abstract}

(Sennet, 98. P. 9)

Esta passagem de Sennet ecoa as ideias que vimos anteriormente em autores como Nelson da Silva Jr. e outros que marcam esta interface que nos parece 
inseparável da dimensão política. Neste campo mais amplo da influência da cultura no social e, especialmente, na formação das subjetividades e identidades de trabalho, dificilmente encontramos autores que assumem uma posição neutra como Lipovetsky; a imensa maioria desses pesquisadores estabelecem uma visão clara dos efeitos nocivos ou mesmo patogênicos das práticas hipermodernas - e, mais além, neoliberais - nos trabalhadores.

No entanto, para traçar novas hipóteses sobre esse campo, há correntes teóricas que buscam o aprofundamento de dimensões ligadas ao indivíduo, ou mesmo à relação do indivíduo com seus colegas ou supervisores. Neste sentido, faz-se essencial explorar uma das maiores forças que compuseram o cenário teórico atual: a evolução das teorias francesas da psicopatologia e psicodinâmica do trabalho ao longo deste período. 
O trabalho nunca é um cenário, ou um ambiente. Ele engaja a subjetividade inteira. Nunca será neutro quanto à saúde do indivíduo: às vezes constrói, às vezes destrói.

(Dejours, 2015. P.107. Trad. Livre)

O trabalho e seus efeitos no homem podem ter uma função vitalizante, emancipadora e central na constituição do Eu em sua relação com a sociedade; no entanto, a relação com o trabalho - e especialmente seu estudo - nascem da demanda de compreender e mitigar seu potencial destrutivo. Ainda assim, foi um progresso lento. Somente a partir do Século XVIII surgiram as pesquisas que culminaram no surgimento da Medicina do Trabalho e suas inúmeras ramificações, desde a Ergonomia, Ergometria e outras práticas que estudam a relação dos corpos com o trabalho.

Entre 1800 e 1900 o estudo da relação Homem-Trabalho avançou consideravelmente, com forte apoio da embrionária corrente técnicoadministrativa. Com um claro foco na produção, prevenção de perdas, produtividade e, especialmente, controle da fadiga, as metodologias científicas se refinavam e apoiaram a construção dos modelos que até hoje se veem em prática. O Fordismo, o Taylorismo, as metodologias de controle de tempos e movimentos foram sofisticadas, e cada vez mais ganharam apoio das nascentes formas de estudo das motivações, comportamentos e melhoria nas condições de trabalho que marcaram o surgimento da Psicologia do Trabalho. Ainda não havia uma 'psicologia' estabelecida, mas as precursoras da Psicologia do Trabalho debatiam estudos associados à produtividade e eficiência: como produzir mais e melhor e, ao mesmo tempo, mitigar riscos. Conforme a metodologia de pesquisa psicológica nos Estados Unidos e Reino Unido evoluíam, avançava a sofisticação de suas teses. Muito influenciada pela indústria 
da guerra e dos grandes deslocamentos do início do Século $X X^{17}$, a Psicologia Organizacional se consolidou como um aliado das grandes organizações em assegurar um melhor uso dos recursos investidos. Seu desenvolvimento foi especialmente expressivo no mundo anglofônico, no qual o avanço científico, o ambiente político e mesmo a tradição protestante criavam um cenário fértil para o desenvolvimento da técnica aliada à atenção aos sentimentos e aspirações. Nesta tradição floresceram a escola Sócio Técnica inglesa, a Psicometria, e, em paralelo, algumas formas de Psicopatologia do Trabalho.

Antes de uma síntese sobre alguns elementos desta evolução, é importante clarificar nossa escolha por tomar como referências principais autores da Escola Francesa (Psicopatologia, Psicodinâmica e Socioclínica do Trabalho). Como veremos adiante, trata-se de uma produção de autores fortemente influenciados pela psicanálise; desde os pioneiros, em sua maioria tratava-se de psicanalistas, psiquiatras conectados ou mesmo críticos à psicanálise. A partir de nossas referências clínicas, este seria um diferencial marcante frente, por exemplo, os trabalhos de autores norte americanos. Além disso, a tradição da Psicologia Positiva e do Pragmatismo influenciaram o corpo teórico dos Estados Unidos a uma forte orientação quantitativa e de forte inspiração empírica.

Embora os autores de origem inglesa tenham uma forte tradição clínica - por exemplo, nas produções ligadas ao Tavistock College - seria impossível mapear este campo específico sem um aprofundamento nas influências de autores como Melanie Klein, Wilfred Bion e Donald Winnicott, além da influência dos autores precursores da Administração de Empresas.

O campo de pesquisa dos autores franceses nos parece, assim, não apenas o mais maduro dos que encontramos, mas também apresenta uma série de exemplos clínicos e organizacionais que se assemelham em grande medida a dilemas percebidos em grandes centros urbanos brasileiros na contemporaneidade. Diferentemente dos países anglo-saxões, a legislação

\footnotetext{
${ }^{17}$ Muitas metodologias de avaliação psicológica nasceram de projetos militares. O LPA, para citar um exemplo, é um inventário inicialmente utilizado para identificar os candidatos - assim como eliminar potenciais ameaças - no processo de deslocamento entre Reino Unido e Austrália.
} 
trabalhista francesa traz elementos similares à brasileira, o que também ocasionou problemas similares nos trabalhadores franceses ou imigrantes que lá se instalaram. Em suma, há paralelos interessantes que nos conduziram à escolha deste campo e na busca das semelhanças entre França e Brasil; a maior dela, talvez, justamente esteja nas dissonâncias e rupturas que acompanharam o desenvolvimento dessas Escolas distintas.

É difícil mapear com a mesma precisão a evolução deste trabalho no mundo francofônico; se por um lado, os principais autores continuam produzindo de forma prolífica, por outro, há profundas divergências sobre a origem de escolas, conceitos e teorias. Se pudermos tomar a licença para criar uma hipótese sobre essa evolução ${ }^{18}$, diríamos que, em grande parte, o avanço das teorias atuais francesas surgiu como uma oposição ou discordância frente aos modelos anglofônicos, esses últimos bastante inspirados pela Administração de Empresas. Se o grande influenciador no mundo inglês foi a fertilidade e entusiasmo capitalista, no campo francês podemos marcar quatro grandes eventos: o Colóquio de Bonneval de 1946, os Movimentos Estudantis de 1968 e, antes disso, os Movimentos de 1945 sobre a Previdência Social.

As décadas de 1950 e 1960 na França tiveram um papel essencial no que viria a ser a Clínica do Trabalho, suas múltiplas correntes, e possivelmente as pesquisas de duas autoras, Isabelle Billiard e Pascale Molinier - respectivamente 2001 e 2006 - são dos trabalhos que melhor detalham esses movimentos ${ }^{19}$. Segundo Billiard, o surgimento da Psicodinâmica do Trabalho teve grande influência de dois períodos delimitados "dos anos 1910 aos anos 1960 para o que concerne a psicologia do trabalho e de 1945 ao fim dos anos 1960 para a psicopatologia

\footnotetext{
${ }^{18}$ Para dar um exemplo da amplitude necessária para se discutir em profundidade este tema, somente na questão da evolução do movimento marxista na França temos uma produção monumental. Para citar alguns: George Lichtheim, "Marxism in Modern France" (1966); Michael Kelly, "Modern French Marxis" (1988); Alexandre Zévaès, "De l'introduction du Marxisme en France" (1947); Georges Weill, "Histoire du Mouvement socialiste en France, 1852 - 1924" (1924); Georges LeFranc, "Le Mouvement Socialiste sous la Troisème République" (1963). (Derfer, 1991. P. 231 - 237).

${ }^{19}$ Uma análise desta linha do tempo também pode ser encontrada no trabalho de Selma Lancman em parceria com os Seiji Uchida (FGV) e Laerte Sznelwar (Poli-USP, coordenador do estudo) intitulado "Trabalhar na magistratura, construção da subjetividade, saúde e desenvolvimento profissional", de 2015.
} 
do trabalho, sempre operando os retornos necessários aos períodos anteriores" (Billiard, 2002 (1). P 213).

Segundo Billiard, os movimentos psiquiátricos do século XX na França foram beneficiados por trabalhos extremamente fecundos que buscavam reformar o modelo do tratamento moral da loucura. Ao mesmo tempo, tentavam dar conta das tentativas de reintegração dos pacientes psiquiátricos pelo estabelecimento de tarefas que buscassem recriar o ambiente social do trabalho, e gradualmente preparar o sujeito para reabilitação ao que era visto como o 'trabalho real', assalariado.

Se trataria de sair dos esquemas de causalidade ou pertença lineares para atualizar os efeitos de um encontro entre duas formulações maiores - aquela da instituição psiquiátrica e a esfera do trabalho -, digamos a conjunção inesperada de dois conjuntos de significações novas que, até então, funcionavam de forma separada. Dito de outra maneira, no pós-guerra e por motivos externos à instituição psiquiátrica (a guerra, a experiência dos campos de concentração, a ascensão do marxismo e da psicanálise, os Movimentos de 1945 sobre a Previdência Social, a difusão da Organização científica do trabalho) se desenha uma configuração nova. De um lado, a antiga categoria do "tratamento moral da loucura" escapava ao trabalho real; de outro, o "trabalho dos alienados" (desde 1838) escapava da saúde mental. Estes dois irão progressivamente entrar em coalescência e fazer sentido através de um novo registro de pensamento e ação - a psicopatologia do trabalho -, assegurando um ponto entre "trabalho terapêutico" e "trabalho real", assalariado, e desta forma marcar uma ruptura com as categorias preexistentes.

(Billiard, 2002 (1). P 213. Trad. livre)

Se a psicopatologia do trabalho teve seu florescer na França dos anos 1960, para

Billiard a origem do termo aconteceu anos antes. Em um texto sobre os 'Pais Fundadores da Psicodinâmica do Trabalho', a autora credita o surgimento do termo cerca de uma década antes disso, para descrever práticas inovadoras desenvolvidas no pós-Guerra que possuíam um viés diferente em relação ao mundo do trabalho. Este texto detalha as origens das ideias centrais que comporiam o campo nos 50 anos seguintes, e contextualiza elementos centrais de sua construção.

O termo 'psicopatologia do trabalho' aparece em 1952 na escrita de Paul Sivadon, em um artigo na L'Évolution Psychiatrique (Sivadon, 
1952). Ele aponta pela primeira vez a existência de um conjunto de práticas inovadoras e de questionamentos pós final da Segunda Guerra mundial, que uniram um punhado de psiquiatras militantes na mesma medida em que os dividiu.

(Billiard, 2002 [2] (2). P 11. Trad. livre)

Para esta autora, Paul Sivadon teve um papel tão essencial na origem de ideias que influenciariam o campo da psicodinâmica do trabalho como Henry Ey com os conceitos debatidos no Colóquio de 1946.

\begin{abstract}
Sensível ao organo-dinamismo de Ey, emprestando de Janet e então Piaget - ainda mais, Freud - [Paul] Sivadon considera que a doença mental tem como causa uma alteração das "estruturas superioras assegurando as funções adaptativas". Esta [a doença] seria traduzida por uma "regressão" em apelo às estruturas funcionais mais sólidas, uma vez que as mais antigas não mais lograriam uma "adaptação satisfatória ao meio". Segundo ele, o objetivo de toda terapêutica psiquiátrica é "a restauração mais completa o possível do valor social do doente". (...) Desde o início, se constata que "ao modificar o objeto, [o sujeito] modifica a si". Ele também marca que o interesse não pode ser mantido se não "houver uma certa lacuna entre o objeto do trabalho e as estruturas mentais do sujeito, devendo haver algo desconhecido no problema, uma tensão a resolver". Essas noções da lacuna, do desconhecido do problema, da tensão a resolver o conduzem para além da análise psicológica do trabalho, ao sublinhar o que é da ordem da prova do real no trabalho, assim como as relações sempre incertas entre sujeito e objeto que, na atividade do trabalho, envolvem a autonomia subjetiva ou - ao contrário - a repetição.
\end{abstract}

(Billiard, 2002 [2]. P 13, Trad .livre, grifo nosso)

Para entender melhor as discussões entre Ey e seus colaboradores, vale aprofundar nos temas tratados no Colóquio de Bonneval. Isabelle Billiard mapeou nas discussões deste congresso algumas das noções fundamentais que reapareceriam na psicopatologia e na psicodinâmica do trabalho.

(...) O modelo organo-dinâmico (Ey, 1975) recolocava a doença mental em uma perspectiva ao mesmo tempo genética e dinâmica da organização do ser humano, ou seja, um processo de diferenciação e complexidade progressiva do sistema nervoso entendido como sistema hierarquizado e integrado de "funções". A doença mental corresponderia assim a uma "desorganização" ou "dissolução" das funções nervosas superioras, digamos, uma "regressão do desenvolvimento psíquico" e uma reorganização em um nível de funcionamento inferior. O grande salto operado por Henry 
Ey consiste em considerar que a vida psicológica está ancorada no orgânico, e, ainda assim, constitui um registro autônomo respondendo a regras e funcionamentos específicos.

(...) Henry Ey definia a psicogênese como o plano da atividade psíquica normal, "verdadeira e livre", ou seja, realizando a subordinação do orgânico pelo psíquico. Jacques Lacan propõe o princípio de uma "psicogênese pura", entendido como causalidade psíquica da doença mental, e postula que "a loucura é um fenômeno do pensamento.

(Billiard, 2002 [2]. P 12 - 13)

Essas referências são importantes para compreender os desdobramentos nas teorias francesas pós 1980. Os temas do debate do Colóquio de Bonneval de 1946 - ou seja, 6 anos antes mesmo que o termo psicopatologia do trabalho fosse criado por Paul Sivadon - foram das pedras fundamentais para o nascimento dessas ideias. Evidentemente, esse desenvolvimento passará por reveses e inversões, mas foi aí que surgiram discussões essenciais como a questão da normalidade no sofrimento no trabalho e especialmente o quanto a doença mental seria um processo eminentemente orgânico (e, desta forma, endógeno) ou se poderia se pensar na influência do social no psiquismo ou na interação dos dois elementos, o laço social, assim, influenciável pela natureza do trabalho e seus efeitos. A marca deste Colóquio será reforçada posteriormente pela polêmica condenação da psicanálise feita pelos autores de orientação marxista, três anos depois.

O Colóquio de 1946 condensa as clivagens que irão atravessar a psiquiatria nos anos a seguir, e as primeiras formulações de uma psicopatologia do trabalho carregarão a marca destes debates internos e não superados. A essas divisões teóricas será necessário acrescentar a condenação da psicanálise pelo Partido Comunista em 1949 e o clima de guerra fria que irá contribuir para o isolamento dos psiquiatras comunistas.

(Billiard, 2002 [2]. P 13)

Um olhar complementar sobre essas bases teóricas pode ser encontrado no trabalho da autora Pascale Molinier. Molinier publicou um livro essencial em 2006 intitulado Os Desafios Psíquicos do Trabalho (Les Enjeux Psychiques du Travail) que inicia justamente com essa cronologia e 'genealogia' das bases teóricas que 
abriram espaço para o florescer deste campo, no qual cita amplamente as pesquisas e Isabelle Billiard. Neste trabalho, Molinier amplia essa leitura do plano 'histórico e temático' das primeiras teses em psicopatologia do trabalho publicadas em 1950 (e, assim, precursoras dos movimentos estudantis e operários de 1968) ${ }^{20}$. Para entender o impacto do Colóquio de Bonneval é essencial conhecer as diferentes orientações teóricas dos influenciadores do que se tornaria a Psicopatologia do Trabalho, em especial as contribuições de Henry Ey $(1900$ - 1977) e Louis Le Guilland (1900 - 1968), participante do grupo 'A Evolução Psiquiátrica' e próximo de Ey e Jacques Lacan. Le Guillant foi um dos signatários do impactante "A Psicanálise, uma Ideologia Reacionária" e teve uma participação chave no Colóquio de Bonneval, de 1946, no qual foram discutidas as teses da organogênese, a psicogênese e a sociogênese da doença mental. (Molinier, 2006. P. 12 - 14) A organogênese da doença mental foi o foco de Henry Ey e um passo fundamental no debate da questão da normalidade e a doença: como traçar uma linha separadora entre o normal e o doente? É nesta discussão em que ele se posicionou de forma a repudiar "toda a psicogênese, toda causalidade psíquica dos transtornos mentais" (Molinier, 2006. P. 15). Para Ey, "as doenças mentais seriam uma desorganização do corpo ou dissolução do "corpo psíquico" no qual "o espírito consciente constitui a forma". "Se um ato, uma ideia, ou uma crença são normais, não quer dizer outra coisa senão que estes são psicogenéticos e se fossem anormais seria justamente por não serem o efeito da livre ação da atividade psíquica, na medida que seriam a consequência das alterações que são, por sua vez, substratos orgânicos infringidos ao pensamento". (Molinier, 2006. P. 15)

A autora marca precisamente a antítese desta proposta, defendida por Jacques Lacan em um texto duro, mas engajado - prévio mesmo aos conhecidos Seminários que o fariam alcançar notoriedade ${ }^{21}$.

A tese da psicogênese da doença mental é defendida por Jacques Lacan em referência à psicanálise: "A loucura é um fenômeno do

\footnotetext{
${ }^{20}$ Essa proposta de Molinier é confirmada quase que integralmente por Dejours em seu Psychopathologie du Travail (2012, P. 3 - 9)

${ }^{21}$ Uma versão editada da fala de Lacan em Bonneval pode ser encontrado em seus 'Escritos', em um texto chamado "Formulações sobre a causalidade psíquica" (Lacan, 1998. P. 152 - 194)
} 
pensamento" dirigido pelo registro psíquico e a dinâmica das identificações desligadas de toda causalidade orgânica. "É no outro que o sujeito se identifica e mesmo se comprova desde o início". Os germes da loucura residem nos efeitos de alienação do imago: "Longe da ideia que a loucura seja o fato contingente das fragilidades de seu organismo, ela está na virtualidade permanente de uma falha aberta em sua essência. (...) O ser do homem não somente não pode ser entendido sem a loucura, mas ele não seria o ser humano se não trouxesse em si a loucura como limite de sua liberdade.

(Molinier, 2006. P. 15 -16)

Não à toa, ao posicionar o delírio como uma tentativa de cura, Henry Ey afirma que Lacan teria destruído o objeto essencial da psiquiatria. Trata-se, à época, de um dos muitos pontos de vista discutidos; Julien Rouart deu o passo fundamental ao recuperar as referências teóricas de Durkheim, Halbwachs e Bonnafous para acrescentar a essa fórmula o elemento da etiologia sócio-gênica da doença mental: aberta essa porta, se fez possível pensar não só nos fatores intra ou intersubjetivos para a origem das patologias mentais, mas também nas possibilidades que as interações sociais - e especialmente o trabalho - fossem um campo potencialmente influente na patologia mental, com uma pesquisa especialmente ligada ao tema do suicídio.

Um ponto de inflexão foi possivelmente a publicação da tese da sociogênese das doenças mentais, de inspiração marxista e defendida por Swen Follin e Lucien Bonnafé. Uma vez que o orgânico influencia o psíquico, o psiquismo pode tutti quanti influenciar o orgânico. Os autores propõem uma psiquiatria concreta que estuda o homem em suas condições e contexto, em um momento histórico específico e nas próprias condições de vida.

É no trabalho de Le Guilland que temos mais recursos para pensar como a construção de uma psicopatologia do trabalho foi profundamente influenciada por uma aliança entre o campo do estudo das doenças mentais e a integração entre saúde e sociedade. Esse autor foi Influenciado por um 'renascimento' da psiquiatria francesa: uma geração inquietada pela busca de uma melhor integração entre o doente mental e a sociedade. Le Guillant se opõe à prática comum a seu tempo chamada de 'trabalho terapêutico' - atividades não 
remuneradas e muitas vezes mais próximas do que pensaríamos como meras formas de ocupar o tempo do louco e torná-lo produtivo. Para que o trabalho seja um instrumento de realização, deveria seguir as mesmas regras e pressupostos do trabalho assalariado. No entanto, o que teria levado um indivíduo a adoecer e outro não?

Para Le Guillant (...) ao encarar o trabalhador em seu transtorno, assim como um doente em hospitais psiquiátricos, a interrogação principal é a mesma: quais são os acontecimentos biográficos, as condições de vida e do trabalho, as formas de condicionamento que constituem o território do processo psicopatológico? O estudo das condições concretas do trabalho é, desta forma, uma via de acesso a uma psicopatologia do trabalho digna deste nome, e a tarefa do psiquiatra consiste em ajudar os trabalhadores a colocar em palavras suas impressões tristes mais ou menos vinculadas a fim de serem capazes de agir em sua própria voz.

(Billiard, 2002 [2]. P 20. Trad. livre)

Assim, Le Guillant integra a questão social, circunstâncias em torno do sujeito ao adoecer e a vida do trabalho para pensar na questão psicopatológica. Diferente de Kraeplin que olha o que considera as instâncias inerentes ao humano que constituem a própria subjetividade - afeto, cognição e vontade - ou de Henry Ey, que buscava uma origem orgânica dos transtornos mentais, Le Guillant pensa que entender as condições de trabalho são uma das vias possíveis para decifrar o sofrimento mental. Foi em sua pesquisa com as telefonistas - um grupo frequentemente estudado pelos pesquisadores - que muitas de suas teorias ganharam mais contorno.

Em um primeiro tempo, Le Guillant se interroga sobre a frequência dos transtornos encontrados entre os telefonistas. Apoiado na análise sistemática de um certo número de casos clínicos, ele realiza com J. Bégoin o estudo intitulado "O Trabalho e a Fadiga: a neurose das telefonistas e dos mecanógrafos" (Le Guillant, Bégoin, 1958). Esse estudo comparado o conduz à conclusão de não se tratar de uma "neurose experimental" própria a certas profissões, mas de verdadeiras "doenças da produtividade" confirmadas pela frequência dos transtornos ligados às formas recentes de racionalização das tarefas, à intensificação do trabalho e aceleração das cadências destinadas a aumentar o rendimento. Sobretudo, Le Guillant que, em certo momento, rompeu com as "teorias reacionárias", baseia sua tese na psicofisiologia pavloviana. Nesta perspectiva, que confere ao substrato cerebral "material" um papel determinante, o sentimento de "assédio" e os transtornos de humor sentidos pelos empregados não 
seriam senão o "reflexo subjetivo" de alterações psicofisiológicas. A partir daí o registro essencial da experiência negativa do trabalho é tomada como uma forma de epifenômeno da sobrecarga cerebral particularmente alarmante em certos tipos de tarefas - e relegado ao segundo plano da análise.

A pesquisa sobre os "incidentes psicopatológicos da condição da empregada" (IIncidences psychopathologiques de la condition de bonne à tout faire] Le Guillant, 1963) opera um deslocamento radical em direção ao outro polo da análise dialética: aquele da "condição social".

(Billiard, 2002 [2]. P 20. Trad. livre)

Vimos até aqui um esforço da psiquiatria francesa em encontrar meios para reintegrar o doente mental à sociedade. Dentre as ferramentas utilizadas, o 'trabalho terapêutico' visava reproduzir nos sanatórios certas condições essenciais que a sociedade proporcionava - ou impunha - a esses indivíduos, uma necessidade de utilidade e produção. No entanto, estes pensadores revolucionários questionaram não só a artificialidade do cenário proposto como sua ineficiência na reabilitação. Propunham - como Lacan - o questionamento mesmo da própria noção de normalidade e saúde mental. Se a loucura é um fenômeno eminentemente humano e parte integrante do pensamento como não refletir sobre o trabalho como uma função constitutiva do Eu em suas facetas de fenômeno social? Podemos pensar que um trabalho simulado, reduzido em suas condições, não seria tão persuasivo ao sistema psíquico a ponto de oferecer possibilidades de realização de si. É esse vínculo extremo entre 'realidade social' e funcionamento saudável que levam Le Guillant a atestar o vínculo indissociável entre trabalho e psique, ainda no seu trabalho sobre as telefonistas (e que, posteriormente, seria revisto e confirmado nas pesquisas realizadas por outros autores com profissionais de telemarketing).

Aqui, as condições do trabalho, a penúria, o salário derrisório são um peso imenso para alguns, mas são indissociáveis dos aspectos psicológicos realizando uma forma global de experiência, uma "gestalt social" diz Le Guillant, infiltrada pelo ressentimento em relação a este "estado" servil do qual não podemos escapar. Apoiando-se algumas vezes na fenomenologia hegeliana, ele faz uso nos recursos deste ódio fundamental dos servos em relação a seu mestre, e a culpabilidade alimentada pela censura que recalca no inconsciente social os problemas originados pela dominação. A solidão existencial, a ambivalência de sentimentos reduzidos ao 
silêncio gera "essa noite para eles mesmos na qual se amarram os conflitos mais profundos", ou seja, uma configuração na qual a alienação mental tece laços estreitos com a alienação social. Isso feito, Le Guillant traz um dado fundamental para a psicopatologia do trabalho: a experiência da relação de subordinação que liga um número crescente de empregados a seu empregador.

(Billiard, 2002 [2]. P 21, Trad. livre)

A análise de Isabelle Billiard nos mostra a abertura desta porta pela qual o estudo do trabalho passa a ser fundamentalmente ligado à subjetividade. Se Le Guilland contribuiu de maneira essencial a mostrar esse vínculo, Claude Veil irá aprofundar essa análise e lançar as bases para o que posteriormente se desenvolverá como a Psicopatologia e Psicodinâmica do Trabalho, como disciplinas e campos teóricos.

Mais que um enquadre clínico ou sobre a estrutura de personalidade do trabalhador, C. Veil se interessa pelos movimentos dinâmicos que assinalam os riscos do funcionamento psíquico: "A doença é considerada o cruzamento de um umbral de desadaptação para além de uma margem de tolerância "(Veil, 1957). Ao mesmo tempo, estima que nenhum indivíduo pode ser dito adaptado ou desadaptado senão em relação às normas determinadas, e conforme o espírito da psiquiatria social, julga ser a missão do psiquiatra ajudar a coletividade igualmente a revelar "a imperfeição das normas" do trabalho a fim de remediar seus efeitos patogênicos. Assim, Veil opera um ir e vir permanente entre dois registros: uma clínica de margens de tolerância individuais e uma colocação em perspectiva psiquiátrica das normas do trabalho.

Face aos transtornos individuais, ele faz prevalecer uma posição temperada segundo a qual "é necessário renunciar aos postulados da unidade e da especificidade dos fatores" e aceitar o emaranhado das experiências. Efetivamente, e assim ele o chama, o homem no trabalho e o homem em sua vida privada são o mesmo homem. "A etiologia é sempre mista", e a desadaptação latente ou manifesta corresponde a uma "saturação dos mecanismos de defesa" na qual é difícil separar o que revela traços de personalidade, da vida pessoal e da vida profissional.

(Billiard, 2002 [2]. P 22. Trad. livre)

Adaptação e desadaptação, fracasso dos mecanismos de defesa; são termos e temas que irão reaparecer constantemente nas discussões posteriores. Billiard é categórica em apontar o papel desses "Pais Fundadores" da clínica do trabalho. Efetivamente, uma genealogia se faz impossível de perder de vista. Ela reconhece 
a importância do contexto das transformações do trabalho como elemento essencial para a geração dessas ideias. As transformações rápidas do trabalho no pós-Guerra não seriam dissociáveis da aparição desses transtornos individuais, mas essa geração de psiquiatras irá buscar na questão da causalidade respostas ao fenômeno. "As diferentes formulações de uma psicopatologia do trabalho não são senão o reflexo das tensões na qual essa geração de psiquiatras habita. Alguns irão atribuir o tom sobre as particularidades do trabalhador frente a seu trabalho; outros às condições de trabalho consideradas como causa última dos transtornos incriminados”. (Billiard, 2002 [2]. P 19) Paul Sivadon vai ainda mais longe; considera que 'as transformações rápidas do meio urbano e do meio técnico representam fatores inegáveis da fragilização dos indivíduos e que a psiquiatria teria como missão fazer recomendações permanentes de prevenir ou atenuar seus efeitos nefastos' (Billiard, 2002 [2]. P 19. "O trabalho não é patógeno em condições gerais senão pelas razões extrínsecas que tomam vantagem das potencialidades dos trabalhadores contra sua própria natureza". O trabalho se torna fonte de sofrimento por essas dificuldades exteriores que geram, em si, essa desadaptação que nomeamos as 'neuroses do trabalho'. Os quadros clínicos que vão da inibição à intolerância, crises de angústia ou a somatização precedida por episódios confusionais ou delirantes, sempre serão uma relação chamada 'imaturidade da personalidade'. O homem provido de mecanismos adaptativos eficazes irá traduzir esse incômodo como fadiga, tédio ou desinteresse, e os transtornos aparecem no momento que a personalidade fragilizada não pode mascarar esses elementos pelo critério da adaptação ou mesmo pelo costume ou acomodação. (Billiard, 2002 [2]. P 19)

Efetivamente essas são as bases nas quais a Psicopatologia do Trabalho irá se desenvolver, e inúmeras ideias posteriores - e profundamente atuais - tomarão sua base. No entanto, um elemento social irá intensificar toda essa discussão: os movimentos esquerdistas franceses de 1968.

Em maio de 1968, a França se viu tomada por violentos protestos e greves gerais motivados por um pensamento anticapitalista, anti-imperialista e especialmente 
contra o poder do General De Gaulle. A França pós Segunda Guerra Mundial se via em uma alta instabilidade; houve uma sobreposição inédita de movimentos estudantis e movimentos operários que criticavam duramente a sociedade de consumo, reivindicavam melhores salários e condições materiais e especialmente contestavam as autoridades em vigor. A crise interna dos partidos marxistas franceses, aliada à influência de movimentos como a Primavera de Praga, Revolução Cultural Chinesa, rejeição à Guerra do Vietnam, democratização das universidades e uma autonomia inédita dos jovens deram condições para que esse momento fosse um dos mais turbulentos e marcantes na história intelectual da França moderna. Esses movimentos possibilitaram uma influência do pensamento marxista e socialista, especialmente nas ciências humanas, desde o final da Segunda Guerra Mundial e alcançando seu ápice na década de 1970. Esse pensamento se consolidou como uma sistemática de pesquisa e alcançou seu ápice entre os anos 1975 e $1980^{22}$.

Vale ainda mencionar a importância do trabalho de Alain Wisner. Em 1970, a Ergonomia foi a grande impulsionadora do conceito de que mais que adaptar o homem ao trabalho, seria essencial adaptar o trabalho ao homem. Esse pensador essencial para o que posteriormente seria a Psicodinâmica do Trabalho foi um médico que decidiu se dedicar à Ergonomia desde 1952, tornando-se em 1970 o diretor do CNAM (posteriormente liderado por Christophe Dejours). É sob sua influência que a Ergonomia alcançou sua importância teórica especialmente entre estudantes e sindicalistas, assim como a elaboração da noção da atividade profissional como "um compromisso a ser encontrado entre uma intenção inscrita em uma história e um projeto, solicitações e adversidades exógenas provenientes do ambiente material e relacional mais ou menos estável - e endógenas, provenientes do estado fisiológico e psicológico não estável”. (Molinier, 2006. P. 71)

\footnotetext{
${ }^{22}$ Guy Lemarchand, «Marxisme et histoire en France depuis la Deuxième Guerre mondiale (Partie I)", Cahiers d'histoire. Revue d'histoire critique ("Marxismo e história na França desde a Segunda Guerra Mundial (Parte I), Diários da história. Revista da história crítica" [Online], 120 | 2013, publicado em 01/012014, acesso em 13 Abril de 2016. URL : http://chrhc.revues.org/3104
} 
Neste ambiente intelectual profundamente influenciado pela necessidade de se diferenciar do pensamento da administração de empresas e por essas ideias propostas pelos 'Pais Fundadores' como um grande motor do desenvolvimento do campo da Psicopatologia / Psicodinâmica do Trabalho surgirão trabalhos transformadores. Um destes é justamente o de Christophe Dejours; eis como o autor descreve essa passagem no prefácio da edição de 2008 do livro Trabalho: Usura Mental.

Em 1980 quando este livro foi editado a primeira vez, se tratava de agrupar os dados recolhidos no campo do trabalho e das empresas em vista de relançar a pesquisa em psicopatologia do trabalho.

Em 1993, a segunda edição refletia o alargamento das preocupações clínicas e teóricas sob o efeito da pesquisa interdisciplinar entre psicopatologia do trabalho de um lado, ciências sociais e ciências do engenheiro do outro: tentar dar conta em uma problemática comum dos destinos do sofrimento no trabalho que podem ser tão contrastantes que o sofrimento, em alguns casos, torna-se tristeza a doença mental - enquanto em outros o inverso, ele seja transformado em prazer e um crescimento da identidade e da saúde.

(Dejours, 2008. P. 7. Trad. livre)

Um ponto interessante a ser marcado nesta cronologia é que justamente no prefácio da reedição de 93 de Trabalho: Usura Mental que surge a diferenciação entre a Psicodinâmica e a Psicopatologia do Trabalho. Trata-se de uma mudança que restabelece mais claramente o laço entre as pesquisas de Dejours, Le Guillant e Veil. Trata-se mais do que uma aproximação, mas de uma releitura da relação entre indivíduo e coletividade, saúde e doença, normal e patológico. Essa mudança é radical a ponto de prescrever que a Psicopatologia do Trabalho seja, ela mesma, uma parte componente da Psicodinâmica ${ }^{23}$. Trata-se não apenas de olhar para os processos individuais intersubjetivos, mas pensar na relação do

\footnotetext{
${ }^{23}$ Esta afirmativa de Dejours mencionada por Molinier possivelmente gerou muita polêmica no campo da Psicopatologia do Trabalho. Apesar disso, vem sendo repetida em diversos trabalhos do autor, inclusive em seu último livro, 'Situações do Trabalho' (Situations du Travail, 2016). "É por isso que em 1992 foi proposta a mudança de nome da disciplina. O termo "Psicodinâmica do Trabalho" substituiu aquele de "Psicopatologia do Trabalho". No campo teórico assim ampliado, a psicopatologia do trabalho não é descartada. Ela se torna um setor particular da psicodinâmica do trabalho dedicada à análise etiológica e se encarrega das patologias mentais e "psicossomáticas" ligadas aos revezes do trabalho". (Dejours, 2016, p. 15)
} 
sujeito com sua história, conflitos e traumas e ainda assim considerar a relação deste e de outros sujeitos com o trabalho. Segundo Pascale Molinier:

\begin{abstract}
No texto intitulado "Itinerário Teórico em Psicopatologia do Trabalho", anterior à mudança de nome, ele (Dejours) mantém o termo "psicopatologia do trabalho" e o justifica pois, por um lado, contém a raiz pathos, apontando para o patológico, "ou seja, o sofrimento e não somente a doença ou a loucura", e por outro lado, reenvia à 'Psicopatologia da Vida Cotidiana' de Freud. Desta forma, treze anos depois da primeira publicação do Trabalho: Usura Mental" o enquadramento com as teses de Le Guillant se faz ainda mais manifesto para que as duas teorias possam existir sob o mesmo nome. A psicodinâmica do trabalho se define como a análise psicodinâmica dos processos intersubjetivos mobilizados pelas situações do trabalho. "'Dinâmica' significa que a investigação toma por centro de gravidade os conflitos que surgem no encontro entre um sujeito, portador de uma história singular preexistente àquele encontro e uma situação de trabalho na qual as características são de forma geral, fixadas independentemente da vontade do sujeito". A psicodinâmica do trabalho é um alargamento que "recapitula e radicaliza o que constitui a inspiração mais original" da psicopatologia do trabalho.
\end{abstract}

(Molinier, 2006. P. 53-54. Trad. livre)

É inegável a importância de Christophe Dejours na história da clínica do trabalho. Trata-se de um autor que publicou dos trabalhos mais consagrados e continua atuando fortemente na área. Em seu essencial "Observações Clínicas em Psicopatologia do Trabalho" (2010) o autor menciona as obras que considera consagradas para uma introdução à Psicopatologia do Trabalho: Louis Le Guillant, "Que psiquiatria para nossos tempos?" (1985); Paul Sivadon, Adolfo Fernandez-Zolla, "Tempo do Trabalho e Tempo e Viver" (1983); Isabelle Billiard, "Saúde Mental e Trabalho. A Emergência da Psicopatologia do Trabalho" (2001) Joseph Torrente, "O Psiquiatra e o Trabalhador" (2004); Marie-Claire CarpentierRoy, "Corpo e Alma: Psicopatologia do Trabalho Enfermeiro" (1991); Marie-Claire Carpentier-Roy e Michel Vézina, "O Trabalho e seus Mal Entendidos" (2000), Pascale Molinier, "Os Desafios Psíquicos do Trabalho: Introdução à 
Psicodinâmica do Trabalho" (2006) e seu próprio texto "Trabalho: Usura Mental"2", de 1980.

Para voltar à diferenciação entre psicodinâmica e psicopatologia do trabalho podemos resgatar um seu comentário sobre a noção de normalidade e saúde, que reforça sua menção de que "a psicopatologia do trabalho estava na contracorrente do pensamento dominante nos anos 1970" (Dejours, 2000. P. 37).

Muitos psiquiatras, certamente, pensam que conhecem a normalidade ao longo uma experiência clínica e uma inteligência teórica da loucura. E, assim, a psicodinâmica do trabalho (clínica e teoria da "normalidade" na situação do trabalho) não é passível de superposição à psicopatologia do trabalho clássica (aquela de Louis Le Guillant e Jean Bégoin, 1957), no ponto exato em que é, desde o início, a investigação psicológica das situações ordinárias, na qual as pessoas buscam afastar a doença mental, e não a investigação de descompensações mentais extraordinárias. Certamente, a psicanálise, que coloca em causa a separação convencional entre doença mental e normalidade, é a via real para pensar uma psicodinâmica da normalidade. Mas ela não poderia dar conta de uma teoria da normalidade. A normalidade é uma conquista e as "estratégias" empregadas para conservá-la não são conhecidas nem pela psiquiatria, nem pela psicanálise. Tanto na medicina como na psiquiatria existe a tendência de apreender a normalidade, mesmo a saúde, com a ajuda de conceitos negativos: ausência de doença, silêncio dos órgãos, etc. Essa concepção é errônea. A saúde do corpo é o resultado da luta sanguinolenta ${ }^{25}$ (se nos permitirmos essa metáfora) de regulações fisiológicas contra as perturbações físicoquímico-biológicas. É bem diferente de um estado passivo de ausência de doença caracterizado negativamente. Ocorre o mesmo, aparentemente, com a saúde mental. Existem, ali, "regulações" muito sofisticadas mobilizando as dinâmicas intersubjetivas não somente no campo afetivo (que a psicanálise conhece), mas também no campo das relações sociais e nos laços civis, que a psicanálise ignora e são estudos sobretudo da sociologia e antropologia da saúde, assim como da psicodinâmica do trabalho.

(Dejours, 2010. P. 26-27)

Em 2015, Dejours também detalhou o ponto de virada que marca em sua leitura a psicodinâmica do trabalho, mas explora especialmente a reação política feroz que se opôs à sua pesquisa. Assim como no texto de 1993, o autor aponta como

\footnotetext{
${ }^{24}$ Para facilitar o acesso, todos os nomes dos livros foram traduzidos livremente. Infelizmente a maioria dessas obras ainda não possui uma tradução oficial em português.

${ }^{25}$ No original, acharnée. Tradução livre.
} 
as ideologias de esquerda receberam mal suas propostas de uma nova leitura

que se destacava em certos pontos da corrente psicopatológica do trabalho.

As pesquisas conduzidas em psicopatologia e em psicodinâmica do trabalho têm, desde os anos 1980, após a publicação de minha primeira obra Trabalho: Usura Mental, suscitado reações contrastadas em virtude da política. A suspeita vis-à-vis da psicanálise conheceu seu apogeu com a publicação pelo partido comunista do manifesto "Sobre a Psicanálise, Ideologia Reacionária $26 "$. Apesar de algumas inquietações, sobretudo entre os signatários do manifesto (S. Lebovici, J. Kestemberg, L. Bonnafé), essa suspeita perdurou entre os meios de esquerda e a psicodinâmica do trabalho foi denunciada por eles como uma exaltação das preocupações individualistas e pequeno-burguesas. A análise do sofrimento no trabalho não poderia senão favorecer o nominalismo e desviar os militantes da consciência de classe e da luta de classes. Com a publicação de Sofrimento na França, a crítica se radicalizou. Sublevando a questão da servidão voluntária no trabalho, a psicodinâmica do trabalho teria traído a classe operária, deixando supor que os trabalhadores não seriam somente as vítimas impotentes do poder patronal (ao mesmo em que outros leitores viram, ao contrário, um meio de compreender os impasses e a impotência das estratégias sindicais e políticas clássicas face aos novos métodos de organização do trabalho, gestão e administração, e encontraram recursos para repensar a teoria e a prática da ação política no regime neoliberal). É o primeiro eixo da crítica. O segundo é a replicação da crítica do pós guerra: ao chamar a atenção para o sofrimento no trabalho alimentaria a dor e a vitimização e tornaria nocivo, dessa forma se tornando responsável pela despolitização insidiosa que afeta nossos concidadãos.

Eu penso o contrário: a despolitização efetiva será sobretudo a consequência do fracasso político em elaborar as questões vivas que preocupamos cidadãos ordinários, em particular aquelas que envolvem o trabalho. Efetivamente, os sindicatos e partidos de esquerda têm deliberadamente recusado o encontro com as questões da saúde mental no trabalho, que desde 1968 vêm cobrindo as paredes das grandes cidades com pôsteres denunciando a alienação no trabalho. Trazer o tema do sofrimento no trabalho ao espaço público não corresponde de forma alguma a uma psicologização do social e do político. Ele testemunha a impotência dos políticos de se apoderar da questão da organização do trabalho. Efetivamente, a partir de 1980 aportei os argumentos em virtude dos quais as patologias mentais foram efetivamente ligadas à organização do trabalho (assim como as doenças do corpo são ligadas às condições de trabalho). Ao recusar a psicodinâmica do trabalho, se desqualifica não somente o sofrimento e as patologias mentais, mas jogamos fora o encontro com a questão da organização do trabalho, questão que não tem sido até então reconhecida pelos sindicatos e partidos inteiramente como um problema político como mostrou Bruno Trentin.

(Dejours, 2015. P. 13-15. Trad. livre)

\footnotetext{
${ }^{26}$ Publicado em 1949.
} 
Como esse trecho bastante emocionado atesta, as ideias de Dejours dividem a audiência; alguns o acusam de ter corrompido os ideais políticos que, como já vimos, foram forte influência no nascimento da clínica do trabalho pós 'Renascimento Psiquiátrico'. Outros o apoiam em afirmar a Psicodinâmica do Trabalho como uma evolução das ideias da Psicopatologia do Trabalho. Como veríamos esta cronologia nas palavras de outro autor, antigo colaborador e que tivesse um viés político de esquerda ainda mais marcado?

Um autor que relata esse aspecto essencial da história e política é o psiquiatra e psicanalista Bernard Doray, que traz em seu "Psicopatologia do Trabalho" (2011) um relato de sua própria experiência neste ambiente de pesquisa.

Esse percurso foi enriquecido pela experiência de uma militância política principalmente marxista. Essa relação com o ato político me conduziu a participar da comissão que, em 1982, havia lançado as bases efêmeras de uma psiquiatria pública radicalmente nova, e sobretudo, desde uma missão de pesquisa posta em prática igualmente em 1982 pela esquerda política, pude operar a aproximação da psicanálise com as ciências sociais, notadamente por encorajar as pesquisas sobre o trabalho. (Doray, 2011. P.7)

Esse primeiro dos textos que apresentam a presente obra [o livro 'Psicopatologia do Trabalho'] a ser publicada em setembro de 1973 na revista Economia e Política. Representa uma intervenção oral pronunciada em um colóquio do PCF intitulado: Sobre a gestão das empresas em uma democracia avançada em uma França Socialista. Esse encontro foi presidido por um secretário geral do PCF, Georges Marchais, em um período no qual, para alguns como eu, o Eurocomunismo parecia uma via possível em direção a uma transformação socialista do Oeste e uma democratização concomitante do Leste. (Doray, 2011. P.11-12)

O texto "A ciência e o Taylorismo" foi publicado em 1978 sob o título "As Práticas Científicas no Campo do Trabalho Industrial, a Crise do Modelo Taylorista" na revista O Pensamento (La pensée) fundada em 1939 por Paul Langevin, Georges Politzer, Marcel Prenant e Henry Wallon (...). Neste artigo para O Pensamento, eu partilhava de um não-dito encobridor: a suposta ciência da organização o trabalho (OST) que pretendia ser o taylorismo estava na contramão da marcha científica, uma vez que parecia o desvelar virtuoso de uma suposta aplicação das ciências fundamentais, uma técnica voraz de recuperação dos tempos assalariados não imediatamente úteis. Essa nova racionalidade não levava em conta nada do que chamo das "necessidades humanas", e ela era determinada por uma empresa reforçada nas finanças sobre a produção das condições materiais da reprodução da sociedade. (Doray, 2011. P.13-14) 
Assim, Taylor, com seu "homem-boi", "comparável a um gorila" ou a uma "pequena mula", homem chamado de "John" fosse esse seu nome ou não, exibia a obscenidade do programa de sua invenção. $O$ cientificismo, com a aversão à complexidade e a singularidade, se prestava desde já à uma desumanização de seus objetos humanos. Saindo certamente de potentes aberturas do pensamento, aquelas restavam coladas às lógicas de exploração dos corpos produtivos e dos recursos naturais. Essa forma de pensamento acompanhou o arco das extrações que apertou o passo da expansão do capitalismo em sua fase industrial e colonial. (Doray, 2011. P.14)

Assim, para além de suas diferenças, uma certa comunidade do pensamento sobre o humano reuniu Jules Amar e Taylor". (N. do T: Jules Amar publicou em 1914 o trabalho "O motor humano e as bases cientificas do trabalho profissional'. Paris, Dunod, 1914)

(Doray, 2011. P. 15. Trad. livre)

Era nessa época também que, segundo Doray, Antoine Porot começava a trabalhar na criação da Escola Psiquiátrica de Alger, uma escola psiquiátrica abertamente racista, especialmente frente aos operários de origem estrangeira, 'governados por seu cérebro reptiliano'. (Doray, P. 15) Em 1980, é publicado um texto que retratava uma pesquisa contrária a esse movimento pseudocientífico que se afirmava baseado em modelos comportamentalistas, biomecânicos e bioenergéticos. "O texto intitulado "Desemprego e Existência" foi uma contribuição a uma pesquisa do centro de pesquisas da CGT intitulada "Desemprego e Saúde" (G. De Bernis, J-L Moynot, J. Magniadas e cols.,1980) (...) e se tratava de um coletivo de impressores vítimas de uma demissão coletiva e engajados há quatro anos em uma luta determinada para recusar a liquidação de sua empresa". (Doray, P. 16) Esse e outros trabalhos na área permitiram a criação do ISERES, Instituto Sindical de Estudos e Pesquisas Econômicas e Sociais que atuava como Centro de Pesquisas Nacional e Federal da CGT.

O Doutor Suchet aplicou um método de detecção dos riscos médicos elaborados essencialmente do ponto de vista "socioeconômico". Tomo conta aqui de minha parte dessa pesquisa, à qual decorria da clínica psiquiátrica influenciada pela psicanálise. Tratava-se de tentar uma leitura clínica da situação psicológica dos operários alocados em uma usina desativada em sua resistência, e desta forma longe da extraterritorialidade normalmente adotada pelos psiquiatras e psicanalistas para exercer sua arte.

(Doray, 2011. P. 17. Trad. livre) 
Doray foi apoiado por Cecília Comegno - socióloga brasileira e exilada política Brigitte Motre e Chantal Warin. Esse time conduziu muitas das entrevistas da pesquisa, e geraram uma série de estudos sobre a relação entre desemprego e saúde. Esses trabalhos seguiam um corpus pobre de pesquisa, inicialmente precedido pelas pesquisas com desempregados de Marienthal, de Paul Lazarfeld, Marie Jahoda e Hanz Zeisel (1931-1932), posteriormente prefaciado por Pierre Bourdieu e publicado em 1982. Essas pesquisas geraram frutos: uma intervenção no IX Congresso Mundial de Psiquiatria Social em uma série de textos publicados entre 1985 e 89.

Um evento significativo para esse campo foi também citado por Doray, o Primeiro Colóquio Nacional de Psicopatologia do Trabalho, conduzido em Paris em 1984. Na apresentação da publicação das suas Atas, Christophe Dejours determinou "seis perímetros constituintes da psicopatologia do trabalho: a desadaptação psíquica do homem ao trabalho; a readaptação psicológica dos trabalhadores; os instrumentos de reorganização mental das doenças mentais; os estudos sobre higiene mental; as doenças mentais ocasionadas pelo trabalho e o sexto perímetro, o mais construído, aquele do sofrimento no trabalho. Para cada um deles, salvo o último, foram dados nomes de pesquisadores atuais ou antigos consagrados. Quanto a esse último, duas questões foram propostas aos participantes: o medo e a alienação no trabalho." (Doray, 2011. P. 29-30)

Em Junho de 1989 houve um segundo encontro, também de impacto significativo. Conduzido em Marselha, as Primeiras Jornadas de Psicologia do Trabalho, Ergonomia e Psicopatologia do Trabalho foram organizadas pelo Laboratório de Ergonomia e Neurofisiologia do Trabalho do Conservatório Nacional de Artes e Ofícios (que um ano depois teria a inauguração de um laboratório liderado por Christophe Dejours). Essas jornadas contaram com a presença de um grupo que seria responsável por grande parte da produção intelectual sobre o tema para os próximos anos e até a contemporaneidade. $\mathrm{O}$ evento foi constituído por seis módulos, um deles dedicado à questão Trabalho - Subjetividade, com participação de Yves Clot, Christophe Dejours, Dominique 
Dessors e Christian Jayet, Bernard Doray, Pierre Roche e Alain Wisner. Outro módulo trazia a interface Psicologia Social - Psicopatologia do Trabalho, com Jacques Broda, Michel Cornaton, Jacques Curie, Violette Haijar, Alain BaubionBroye, François Hubault, Michele Rabit, Gerard Mendel e Max Pages. (Doray, 2011. P. 32-33).

Para esse autor, a década de 1980 é marcante por diversas frentes - afinal, em 1980 também ocorreu uma outra transformação importante no campo da saúde mental. Em 1980, sob a direção de Robert Spitzer, a Associação Americana de Psiquiatria publicou o DSM III, no qual a categoria do TEPT foi inaugurada (Transtorno de Estresse Pós-Traumático). Além de trazer à luz a relação entre os traumas de guerra e seus efeitos nos soldados - fortemente influenciados pelas pesquisas realizadas com ex combatentes do Vietnam - também abria espaço no campo da saúde mental para falar sobre os efeitos traumáticos das demissões em massa. "Para abordar essa questão, era necessário abandonar o 'psicanalismo' clássico que subestimava o impacto do real dos momentos traumatizantes em benefício dos efeitos fantasmáticos a posteriori, invariavelmente embasados no traço edipiano. (...) O termo traumatismo não estava tanto em uso quanto o é atualmente, mas a evidência clínica estava lá, e desde então religado aos conceitos freudianos dos traumatismos não sexuais, o que eu entendia como o sofrimento atmosférico que era o preço pago por esse coletivo operário por sua resistência”. (Doray, 2011. P. 19-20)

Enfim, há múltiplas leituras do campo, que nos fazem perceber tanto seu interesse para o pensamento da relação homem-trabalho como mapear a origem de muitas divergências conceituais ou mesmo autorais. Por exemplo, ao ler a cronologia estabelecida por Dejours em 1993 no já mencionado prefácio à Edição de 1993 do livro Trabalho: Usura Mental podemos perceber alguns desses elementos da tensão pós 1968. Segundo o autor (2000):

1973: Primeiras pesquisas na indústria automobilística (antes da introdução da robótica) e nas cimenteiras, conduzidas pelo grupo de pesquisadores do que se tornaria a AOCIP (Associação para a abertura do campo de investigação psicopatológico), enquetes na construção civil, trabalhos públicos, a química, o Exército, etc. 
1978: as pesquisas sobre a saúde mental e o sofrimento no trabalho passam por favorecer as preocupações individualistas contrárias à emancipação. A marcha em psicopatologia do trabalho é desfavorecida por alguns membros do grupo, uma vez que está é julgada fundamentalmente reacionária. Interrupção da pesquisa em psicopatologia do trabalho.

1980: publicação do ensaio Trabalho: Usura Mental, recapitulando a experiência adquirida em campo até 1978.

1983: criação da AOCIP, reagrupando seis participantes, cada um formado em diferentes disciplinas - prevenção, medicina do trabalho, psiquiatria, psicanálise, ergonomia - que se reúnem para relançar a pesquisa no domínio da psicopatologia do trabalho.

1984: primeiro Colóquio Nacional de Psicopatologia do Trabalho organizado em Paris com o apoio do Ministério da Pesquisa e do CNRS.

1987-1988: seminário interdisciplinar de psicopatologia do trabalho inserido no PIRTTEM (Programa interdisciplinar de pesquisa sobre o trabalho, a tecnologia, o emprego e os modos de vida) do CNRS.

1990: constituição de um laboratório no Conservatório Nacional de Artes e Ofícios.

1992: mudança de nome da disciplina: a psicopatologia do trabalho se torna "análise psicodinâmica das situações de trabalho".

1993: Segunda edição de Trabalho: Usura Mental.

(Dejours, 2000. P. 35-36)

Enfim, há inúmeros elementos que criaram condições ideais para o surgimento dos campos da psicopatologia do trabalho e sua 'bifurcação' pós 1993 na psicodinâmica do trabalho após as determinações de Christophe Dejours. As relações com a psicanálise (ou melhor, as psicanálises) podem ser pensadas como mais ou menos harmônicas. Em relação à freudiana clássica, Dejours mapeia com precisão um primeiro ponto de divergência que sua obra vem articulando desde 1980. Na análise de Cristophe Dejours (2010), a análise psicanalítica do trabalho nos indica duas problemáticas específicas em relação ao trabalho.

Tradicionalmente, o trabalho como tal não faz parte do campo da investigação e teorização psicanalítico. Mesmo assim, um lugar lhe foi conferido (...) nas teorizações de Freud sobre a sublimação. Desta forma, podemos recapitular o que nos apresenta a literatura em psicopatologia geral, e destacar duas problemáticas típicas: 
- aquela da escolha profissional, que põe em cena as questões relativas aos investimentos sociais, a sublimação, as identificações, as idealizações e as formas expressivas de suas derrotas no adolescente ou no adulto (vetorização inconsciente $\rightarrow$ trabalho);

- aquela dos incidentes da situação do trabalho sobre a vida psíquica e afetiva do adulto, especialmente sobre a saúde mental ou somática (vetorização sociedade $\rightarrow$ sujeito).

Nestas duas problemáticas encontra-se implicitamente admitida a ideia segundo a qual o trabalho constitui uma dimensão ontologicamente exterior ao sujeito, um elemento de realidade no qual se condensam os dados relativos ao funcionamento da sociedade (hierarquia, dimensão econômica, etc.) e à materialidade das limitações ligadas à atividade (gestos, habilidades, saber-fazer, conhecimentos que devem ser adquiridos - competências - e colocar em prática - desempenho).

Se essa realidade pode ser desestabilizante ou traumática, ela é pensada pela psicanálise como radicalmente estrangeira, não significando em relação à vida subjetiva outra coisa senão um problema de articulação, observado geralmente em termos de adaptação ou ajustamento psíquico.

(Dejours, 2010. P. 85-86. Trad. livre)

Enfim, trata-se de um campo múltiplo, cujas raízes podem ser traçadas desde o encontro entre as ideologias marxistas do pós-Guerra francês assim como os importantes desdobramentos da psicanálise na década de 1960 e 1970. Com a especial importância de trazer à superfície o impasse entre doença mental, 'normalidade' e múltiplas perspectivas sobre como articular saúde, sofrimento e trabalho sem com isso perder a perspectiva individual, podemos perceber como esses autores produziram e ainda produzem inúmeros trabalhos que transitam nestes referenciais da clínica do indivíduo (talvez mais associada às origens da psicopatologia) e das estratégias coletivas de defesa e organizações dos trabalhadores (que tem sido cada vez mais o foco da psicodinâmica do trabalho).

Não haveria descrição melhor destes movimentos do pensamento teórico que as próprias palavras de Dejours em seu texto 'La Panne': "A Clínica do Trabalho funciona efetivamente em um vai e volta permanente entre o campo e os conceitos que ela elabora. Os clínicos do trabalho fazem assim parte dos pesquisadores que têm cada melhor experimentado a 'autoteoria', sem, no entanto, o haver reivindicado. São levados a se submeter constantemente a essa 
prova, que contem sua própria atividade e as relações sociais que atuam nestas. É impensável fazer do trabalho um objeto exterior e o próprio autor não escapa de batalhas políticas, gerenciais que são próprias do campo das pesquisas. (...) Não tenho a intenção de ter razão antes e contra todos, menos ainda de ter soluções prontas para aplicar. Trata-se sobretudo de buscar o trabalho de explicação, fornecer as ferramentas que minhas pesquisas me permitiram construir em quarenta anos, de também relatar as experiências que acompanho até hoje em algumas empresas que decidiram romper com o modelo administrativo. Com uma visão: convencer os sindicatos, os gerentes, os políticos que é urgente e possível colocar em prática uma outra organização do trabalho. Não temos escolha: é necessário reaprender a trabalhar [no original, réapprendre le travail]". (Dejours, 2012. P 37 - 39)

Como iniciamos a discussão, essa relação não está fechada ou consolidada; há inúmeras vertentes que ou seguem as linhas de pesquisa originadas nos anos 1980 como variações muito interessantes como a Sociologia Clínica, com autores como Nicole Aubert $(2003,2004,2011)$ e contribuintes como Eugéne Enriquez, Robert Castel e outros. Essa polissemia é fértil, e mostra como não é uma tarefa simples posicionar o mal estar no trabalho em um ou outro desses campos de pesquisa. E ainda assim, cabe a pergunta: será que é possível para o pesquisador adotar apenas uma destas perspectivas sem, com isso, perder de vista fenômenos que pertenceriam a outros campos 'concorrentes', ou será que a melhor abordagem seria justamente buscar o diálogo e intercâmbio entre essas linhas para tentar evitar a redução do discurso vivo de quem sofre a uma ou outra visão teórica?

Mais ainda, é essencial retornar ao argumento de Lipovetsky que resiste a qualquer tentativa de polarizar em um ou outro extremo a natureza das mudanças da contemporaneidade e, em especial, sua relação com a temporalidade. Recorrendo a uma de suas principais referências, este autor ressalta como "JeanFrançois Lyotard foi um dos primeiros a notar a relação entre a condição pós moderna e a temporalidade do "presentismo." A perda de credibilidade dos sistemas progressistas, a proeminência das normas da eficiência, a 
comercialização do conhecimento, o número crescente de contratos temporários na vida cotidiana: o que isso poderia significar senão que o centro de gravidade temporal de nossas sociedades mudou do futuro para o presente"? (Lipovetsky, 2005. P. 35, trad. livre)

Embora cite Lyotard como um influenciador importante em seu pensamento, Lipovetsky marca repetidamente o caráter de duplicidade da hipermodernidade em todas suas mazelas e vantagens; não se trata especificamente de uma ambiguidade, mas sim de uma convivência de elementos opostos que se articulam de maneiras específicas de acordo com cada indivíduo, suas possibilidades, acessos, recursos. Feita essa ressalva, vale à pena explorar ao que Lipovetsky opõe ao 'presente permanente' de Lyotard no que diz respeito ao uso e experiência do tempo. "As sociedades modernas emergiram em meio a uma imensa 'mudança de tempos' que tornou o futuro mais importante que o presente. No entanto, essa temporalidade dominante trouxe de volta, de maneira secularizada, crenças e formas de pensar do passado, herdadas do espírito da religião (a marcha incessante em direção da felicidade e paz, a utopia do novo homem, a classe redentora, uma sociedade sem divisões, o espírito do sacrifício). Todas essas 'religiões seculares' se lastreiam em esperanças escatológicas que haviam morrido. Nesse sentido, a 'falta de futuro', ou estreitamento do horizonte de tempo na base da sociedade hipermoderna deve ser pensado como a secularização das representações modernas do tempo, um processo de desencanto, ou de modernização da percepção do tempo em si. O declínio no culto mecânico do progresso não pode mais ser confundido com o 'presente absoluto', mas sim com o puro futuro, um que deve ser construído sem quaisquer garantias, sem caminhos pré-ordenados, ou qualquer lei implacável da mudança". (Lipovetsky, 2005. P. 42, trad. livre)

Em seu livro Hypermodern Times, há uma resposta de Lipovetsky para seu entrevistador Travollot que reforça a importância de não reduzir a Sociedade contemporânea a seu caráter universalizado de 'individualista', além de detalhar a complexidade envolvida nesta suposta afirmativa. "Tocqueville, assim como Durkheim, enfatizaram que uma sociedade não pode ser reduzida a produção 
material e trocas econômicas. Não pode existir sem concepções ideais. Não se trata de um "luxo" sem o qual pode existir, mas a condição mesma da existência coletiva, um fato que permite que indivíduos se conectem uns aos outros, tenham objetivos comuns e atuem em conjunto. Sem um sistema de valores não há corpo social capaz de reproduzir a si. A sociedade hipermoderna não escapa a essa lei. Longe de ter causado a aniquilação de todos os valores, a destituição dos grandes sonhos messiânicos políticos foi o que permitiu que as democracias se reconciliassem com os princípios básicos morais: os direitos humanos. De um lado, o individualismo leva a um declínio na força das obrigações morais; por outro, contribui para dar às mesmas uma nova prioridade. Respeito pela pessoa podia parecer secundário quando comparado à revolução, luta de classes, a nação e até mesmo à raça. Não é mais o caso. Temos que para de cantar o antigo refrão de que vivemos em um universo niilista, anárquico, isento de qualquer sentido moral ou crença no bem e no mal: a decadência dos valores é um mito, e um que, não por acaso, é longe de ser novo”. (Lipovetsky, 2005. P. 81, trad. livre)

Esta digressão é um passo importante para marcar uma ressalva ao comparar a realidade mapeada pela literatura francesa e o momento da contemporaneidade e suas mudanças; embora muitos autores como Dani-Robert Dufour, Robert Castel e Nicole Aubert apontem para o potencial patogênico promovido por mudanças sistemáticas nas dinâmicas de trabalho no neoliberalismo ou 'hipermodernidade', devemos precisar alguns conceitos para reconhecer avanços na sociedade na esfera do mal estar no trabalho. Um primeiro ponto é distinguir claramente a ideia de doença mental e trabalho com a doença mental provocada pelo trabalho. Existem casos nos quais esta relação causal é bastante evidente - como em situações de violência ou assédio moral, mudanças radicais provocadas intencionalmente e outras situações em que o vínculo entre o adoecer e o trabalho são diretamente associados. Nessa perspectiva, nossa pesquisa inscreve-se justamente em buscar os casos em que esta relação seja, ao menos para o indivíduo, diretamente relacionada. E, ao menos neste sentido, houve um visível progresso nos recursos legais de apoio ao trabalhador, além de 
inúmeros avanços sociais no sentido de ampliar a inclusão de pessoas portadoras de condições previamente diagnosticadas e tratadas, seguros sociais e mesmo leis que protegem contra estigma e discriminação. Assumir uma posição crítica e dedicada a pensar formas de minimizar o sofrimento não impede de reconhecer que as sociedades têm caminhado - cada qual a seu tempo - no sentido de melhorar algumas das fontes de mal estar que iremos expor nesta pesquisa. 


\section{CAIR, LEVANTAR - OS PROBLEMAS EM ASSOCIAR “SOFRIMENTO” E TRABALHO}

A condição humana é tal que dor e esforço não são apenas sintomas que podem ser removidos sem mudar a vida ela mesma; eles são sobretudo os modos nos quais a vida em si, aliada à necessidade na qual é amarrada, se faz sentir. Para mortais, a "vida fácil dos deuses" seria uma vida desvitalizada.

(Arendt, 2008. P. 120)

Experiências de trabalho saudáveis e vitalizantes contribuem amplamente para o bem estar e felicidade. No entanto, o oposto também é verdadeiro: se o trabalho tem o potencial de ser um campo de realização e desenvolvimento, experiências negativas ou mesmo traumáticas na vida de trabalho podem ter um efeito emocional e físico devastador ${ }^{27}$. E, enfim, trata-se do sistema que alimentamos dia a dia, o que chamamos a organização contemporânea de trabalho. Escolhas feitas e refeitas, mas que potencialmente levam uma maioria de indivíduos a uma condição de mal-estar.

Se constata algo de trágico: o sistema, que atualmente gera um sofrimento até então inédito no mundo do trabalho, não funciona senão pelo nosso zelo e a inteligência que colocamos em prática conjuntamente para fazê-lo perdurar.

(Dejours et Al., 2015. P. 9-10, trad. livre)

Estabeleçamos então um ponto de partida central: a natureza ambivalente do conceito de sofrimento na tradição das escolas psicanalíticas. Haveria de partida uma acepção fundamentalmente negativa do sofrimento, algo a ser evitado e mesmo 'tratado'. No entanto, existe também a face edificante deste conceito: é

\footnotetext{
27 Há estudos que fortalecem esta hipótese de crescimento da percepção, incidência ou sensibilidade ao sofrimento no trabalho. Para citar alguns: Lucero, M. A., Allen, R. E. The Role of Provocation in Workplace Violence: Reviewing Published arbitration Cases. (2014); Hewett, R. Liefooghe, A.P.D., Visockaite, G., Roongrerngsuke, S. Bullying at Work: Cognitive Appraisal of Negative Acts and the Impact on Wellbeing and Performance. (2014); Laschinger, H. S., Fida, R. Longitudinal Analysis Authentic Leadership on Workplace Bullying, Burnout and Turnover Intentions. (2014); Cowan, R. Salin, D. Human Resource Professionals' Perceptions of Workplace Bullying from Across the Globe. (2014); Jacobson, R. P., Hood, J. N. Jacobson, K. J. L. Moral Emotions as Predictors of Workplace Bullying: Reducing the Likelihood of Bullying Perpetration.(2014). Se formos buscar outros meios, podemos citar o trabalho de Christophe Dejours, em especial seu trabalho de fevereiro de 2015 intitulado "Le Choix: Souffrir au Travail n'est pas une fatalité" (2015).
} 
pela via da falta que se organiza o desejo, ou pela ausência de condições que se abre a possibilidade do desenvolvimento e amadurecimento (esta última frase faz uma interface com as teorias de desenvolvimento de Jean Piaget). Não se trata de forma alguma de uma digressão trivial; na abertura do livro "La Souffrance de l'être" (2014), organizado por Jean-Luc Gaspard, há uma longa discussão sobre o tema. O primeiro passo é um jogo de sentidos com a própria expressão francesa: 'O sofrimento do Ser', como sendo algo de posse deste 'Ser", contra “o sofrimento de estar', uma outra tradução possível. No entanto, em sua 'Abertura', o autor Roland Gori ainda faz um novo jogo de sentidos, algo que poderia ser traduzido como 'O Sofrimento de Ser'. Introduzindo-se a dimensão política na análise dos mercados de trabalho contemporâneos, seria possível perceber uma verdadeira retórica das paixões no sentido Aristotélico que remeteria a um pathos do ser. "Ao contrário da debilidade do discurso corrente que pretende organizar atualmente o campo das pesquisas por projetos e apelos das ofertas, cavalo de Troia de uma lógica do mercado no campo do conhecimento, diria que a ambição desta obra bem poderia ser medida na sua capacidade de seu contribuintes em revelar o desafio que seu título impõe, à saber, confrontar o oximoro, 'sofrimento do ser'. (Gaspard, 2014, 18) Enfim, mais um exemplo de uma nova possibilidade de leitura da contemporaneidade que recusa um discurso de vitimização e, ao contrário, desvela toda uma dimensão (ou dit-mensão) bastante sistematizada de criação de discursos patogênicos. Desta forma, talvez melhor que partir do sofrimento, seja importante refletir sobre a possibilidade realizadora do campo profissional.

Dejours também comentou em diversas passagens sobre esse potencial 'engrandecedor' do sofrer no trabalho, e possivelmente a melhor síntese de seus comentários está no Volume 2 de sua obra "Trabalho Vivo".

O sofrimento afetivo - absolutamente passivo - do encontro com o real, enquanto marca de uma ruptura da ação, não é senão o ponto de conclusão, o final do processo que liga subjetividade ao trabalho. [Entretanto,] o sofrimento também é um ponto de partida. Nesta experiência se concentra a subjetividade; o sofrimento torna-se um ponto de origem, na medida exata na qual essa condensação da 
subjetividade sobre si anuncia um tempo de dilatação, de reenvio, de nova expansão que o sucede. O sofrimento não é senão uma consequência última da relação com o real, ao mesmo tempo proteção da subjetividade em sua relação com o mundo, uma busca de meios de agir sobre o mundo, para transformar esse sofrimento em uma pesquisa sobre como ultrapassar a resistência do real. (...) O sofrimento, enquanto afetividade absoluta, é a origem desta inteligência que parte em busca de entender o mundo, se colocar à prova, se transformar, para ampliar a si.

(Dejours, 2013. P. 22, trad. livre)

Apesar destas considerações, refletir sobre o sofrimento no trabalho envolve uma complexidade maior. Por isso, é importante adiantar que o escopo do nosso trabalho foi intencionalmente definido como o trabalho formal, realizado em organizações públicas ou privadas, mas que tenham uma estrutura hierárquica definida e uma função produtiva ou lucrativa imediata. Evidentemente há outros modelos de trabalho bastante diversos, mas aqui optamos por deixar para outra pesquisa a tarefa de investigar, por exemplo, o trabalho em meio acadêmico, o trabalho voluntário, religioso, doméstico ou esotérico ou mesmo a produção artística. Nosso olhar será no trabalho que envolve o que possivelmente é o maior número de pessoas na contemporaneidade, a saber o trabalho em ambiente empresarial ou organizacional. Há também três elementos essenciais que foram deixados de lado na escolha do campo de pesquisa. Não incluímos situações extremas de trabalho como trabalho escravo, trabalho ilegal, situações de guerra, catástrofes naturais ou condições políticas ou econômicas que transformem drasticamente o panorama de trabalho. Nossa percepção é a de que em qualquer desses casos citados há uma transformação inevitável nas relações de trabalho que irá invariavelmente gerar mal estar na grande maioria ou mesmo a totalidade dos sujeitos. Assim, nossa pesquisa será dedicada a pensar em situações mais correntes ou estáveis do mundo do trabalho na contemporaneidade.

Voltando à questão do sofrimento e nossa escolha pelo termo mal estar, a escolha nos parece evitar uma restrição ao foco do indivíduo em sua história singular. O sofrimento é individual e associado a uma falta inerente ao humano, além um efeito inevitável que pode nos levar a buscar respostas sobre si na 
relação com o outro. 'Mal estar' parece mais neutro, no sentido de que o trabalho inevitavelmente promove algum grau de mal estar por sua dimensão de renúncia dos instintos, necessidade de adequação, convivência com elementos como dominação e coerção, entre outros. Desta forma, dizer mal estar no trabalho não implica em dizer que haja necessariamente transformação no sujeito que se queixa, da mesma forma que não há como imaginar um ambiente de trabalho perfeitamente bom ou continente, isento de mal estar.

Outra marca essencial deste significante é que dialoga com Sigmund Freud em seu 'Mal Estar na Civilização', especialmente para pensarmos nessa impossibilidade de considerar que uma relação de (ou com o) trabalho possa ser um caminho único para a felicidade. O início do texto já inaugura o que podemos pensar como mal estar, um certo desencontro entre o que cada sujeito busca na vida e o que de fato o faria bem: "É difícil escapar à impressão de que em geral as pessoas usam medidas falsas, de que buscam poder, sucesso e riqueza para si mesmas e admiram aqueles que os têm, subestimando os autênticos valores da vida." (Freud, 1930/2010, P.14)

Quando seguimos o texto, logo fica claro a escolha de 'mal estar': a felicidade seria algo difícil de alcançar em um contexto 'civilizado'. Essencialmente, as fontes de infelicidade que o convívio organizado nos promove fazem necessário muito esforço para se alcançar uma vida prazerosa - a percepção da fragilidade de nossos corpos, envelhecimento e doença, as imprevisíveis forças da natureza que podem nos destruir a qualquer momento e as frustrações que o convívio social promove. A felicidade plena é inatingível; "Quando uma situação desejada pelo princípio do prazer tem prosseguimento, isto resulta apenas em um morno bem-estar; somos feitos de modo a poder fruir intensamente só o contraste, muito pouco o estado". (Freud, 1930/2010. P 31, grifo nosso)

Daí o 'mal estar no trabalho'; se na vida psíquica já existe uma grande chance do indivíduo que reflete sobre sua condição para ser infeliz ou alienar-se para não percebê-lo, a dimensão do trabalho é um campo privilegiado para isso. 
Nossa pesquisa pode se inscrever no que afirma Doray: "O que diz a clínica? Hoje, os trabalhos de Nicole Aubert e Vincent de Gaulejac sobre as consequências dos pactos "gerenciais" que amarram os executivos de alta performance à sua empresa e de Vincent de Gaulejac sobre a vergonha ligada ao desligamento dos pertencimentos, o trabalho de Maryvonne David-Jougneau sobre a dissidência, o trabalho de Yves Clot sobre o movimento dos desempregados, o livro de Christophe Dejours Souffrance en France [Sofrimento na França], ou ainda a corrente clínica que suscitou o livro de Marie-France Hirigoyen, que define ao assédio moral, temos alertados sobre a potência muitas vezes catastrófica das rupturas do pacto entre o sujeito e o coletivo que se passam nos revezes dos meios de trabalho". (Doray, 2011, P. 188-189)

Nos parece claro o risco de articular sofrimento e trabalho; ainda assim, não se trata de algo a se abandonar completamente. Há uma dimensão essencial na reação Homem-trabalho. Dejours, em seu texto "Le Choix" ('A Escolha', 2015) aponta o sofrimento como uma dimensão inescapável e mesmo integral do trabalho. Se pensarmos que o 'trabalho vivo' 28 ' - em oposição do trabalho inerte, realizado por máquinas e sistemas autônomos - requer uma articulação entre desafios relevantes, comprometimento da 'psique como um todo' e o desenvolvimento das inteligências necessárias para superar esses desafios, o sofrimento é parte essencial do processo (Dejours, 2015. P. 108 -109) 29 $^{29}$ Para que haja desenvolvimento de si e que o trabalho não seja um cumprimento alienado de sequências mecanicamente determinadas por outra pessoa, é fundamental que haja o encontro com esse desconhecido que irá requerer novas habilidades ou inteligências. Esse encontro com o não saber pode gerar

\footnotetext{
${ }^{28}$ Essa ideia é apresentada em inúmeros textos do autor, mas podemos citar, especificamente, Dejours, (Org.) Conjurer la Violence (2007, P.22-23).

${ }^{29} \mathrm{O}$ uso do termo 'sofrimento' para o campo da relação Homem-trabalho é criticado por inúmeros autores, com diferente intensidade. O autor Roland Gori, para citar um deles, assinou a abertura do livro "O Sofrimento do Ser" ('La Souffrance de l'Être', organizado por Jean-Luc Garpard, 2014); neste prefácio ele cita justamente o caráter revolucionário do 'sofrimento no trabalho', e o quanto esse sofrimento coletivo não seria uma forma de combater a uniformidade proposta pelos 'discursos do Mestre', ou "ideologias e ortopedias sociais" que obrigam o sujeito a adaptar-se a seu ambiente, transformando-o assim em "uma peça solta de uma organização social cujo protótipo mais perfeito é a sociedade animal. Sociedade de escravos, que reduz o humano à sua função de instrumento e sua linguagem às interações de máquinas e seus sinais" (Gori, In: Gaspard, 2014. P. 24-25)
} 
desconforto ou mesmo sofrimento, e é através da superação que haverá a evolução e realização no trabalho. Desta forma, torna-se fundamental reforçar que existe uma dimensão de sofrimento que é positiva, evolutiva e mesmo fundamental para que o trabalho seja criativo, engajador e relevante. No entanto, também é central determinar que dimensão de sofrimentos seriam indesejáveis ou mesmo repudiáveis, e desenvolver estratégias para combater essas práticas sempre que possível.

Estes argumentos desenham uma consistência no que constitui a corrente francesa sobre intervenções e pesquisa sobre o mal estar no trabalho, tano em seu caráter de repúdio à ideia mais ingênua do sofrimento como do fator essencial do mesmo na constituição de novas habilidades ou 'inteligências'. Ainda assim, nos parece notável que no mundo anglofônico, estas concepções são praticamente deixadas de lado; em paralelo, uma das técnicas que se mostram mais rentáveis e de rápido crescimento são as inúmeras modalidades concebidas dentro do campo do que se nomeia Coaching.

Desta forma cabe investigar a evolução desta linha de pensamento para nos perguntarmos: afinal, o que faz com que esta forma de intervenção tenha tamanho sucesso tanto em termos de mercado como em sua influência na cultura? 
Nosso estudo tem como desafio situar-se em uma zona de interface e, portanto, um campo de difícil delimitação. Em seu texto 'L'Homme au Travail et son Double" (O Homem no Trabalho e seu Duplo, 2011), Doray já alerta para o risco da 'balade des concepts' que pode ocorrer ao transitar por conceitos que nascem de perspectivas muito diversas ${ }^{30}$. Efetivamente, trata-se de uma aposta metodológica pouco convencional, que báscula do universo intrapsíquico característico da produção psicanalítica clássica ao intersubjetivo, das esferas de estudo do indivíduo da Psicopatologia do Trabalho francesa às estratégias e dinâmicas coletivas e compartilhadas, observáveis nas relações Sociais do Trabalho, e mesmo da relação entre Trabalho e Sociedade abordadas pela Sociologia Clínica, cujo foco é unir debates sobre a relação entre trabalho, cultura e sociedade.

Nossa pesquisa pode se inscrever no que Doray afirma em "O que diz a Clínica? Os trabalhos de Nicole Aubert e Vincent de Gaulejac são fontes necessárias sobre as consequências dos pactos "gerenciais" que amarram os executivos de alta performance à sua empresa, assim como os estudos de Gaulejac sobre a vergonha ligada ao desligamento dos pertencimentos, o trabalho de Maryvonne David-Jougneau sobre a dissidência, o trabalho de Yves Clot sobre o movimento dos desempregados, o livro de Christophe Dejours Souffrance en France [Sofrimento na França], ou ainda a corrente clínica que suscitou o livro de MarieFrance Hirigoyen consagrado ao assédio moral, temos alertados sobre a potência muitas vezes catastrófica das rupturas do pacto entre o sujeito e o coletivo que se passam nos revezes dos meios de trabalho". (Doray, 2011, P. 188-189)

Nesta mesma direção, poderíamos pensar no conceito de mal-estar no trabalho da mesma forma que Audrey Collin se aproxima do conceito de 'carreira' (Collin, 2007. P. 558). Em sua revisão do conceito, essa autora elenca diversas

\footnotetext{
30 "O risco de confusão é sobretudo no passeio dos conceitos: o deslocamento dos conceitos que se referem a um campo da realidade em direção a outro campo estruturalmente diferente". (Doray, 2011. P. 118, trad. livre)
} 
concepções que considera fundamentais, e finalmente adota o paradigma da 'tapeçaria de carreira': na medida em que por mais que se trate de um conceito de fácil compreensão, uma leitura atenta mostra múltiplas perspectivas metodológicas, visões interdisciplinares e complexidades que vão desde o individual, social, econômico e cultural (Collin, 2007. P. 560). Desta forma, mesmo havendo um imenso valor na exploração de hipóteses autorais individuais - os 'fios' desta tapeçaria - seria impossível observar esta multiplicidade sem considerar um todo complexo, que encerra em si conflitos e contradições e que, em última instância, seria profundamente influenciado pelos elementos individuais de cada um, suas escolhas, oportunidades e contexto.

Em nossa discussão inicial apresentamos diversas abordagens metodológicas com trajetórias epistemológicas completamente diversas; as múltiplas correntes francesas que se dedicam ao mal estar no trabalho com suas divergências radicais, mas em perspectiva trazem premissas completamente diversas de outras correntes de pensamento como, por exemplo, o Coaching, ou as teorias sócio técnicas da Administração ou dos Recursos Humanos. No entanto, deparamo-nos na contemporaneidade com dois elementos preocupantes; o primeiro é que profissionais de campos totalmente opostos frequentemente são buscados por uma mesma queixa. Ou seja, para o usuário destes serviços, qual seriam os referenciais ou técnicas utilizadas? Ou mais ainda: em que premissas essas técnicas se baseiam, e em que essas bases influenciam na condução das intervenções? Um exemplo prático: um profissional fundamentado na vitimologia francesa ou em uma técnica mais fundamentada na psicopatologia do trabalho poderia ver um caso em que o sujeito é explorado ou abusado no ambiente de trabalho; neste mesmo caso, uma abordagem mais voltada para a Administração pode dar foco em sua reabilitação, sem questionar as bases das relações de trabalho, e sim no desenvolvimento de "competências" que o façam de reintegrar àquele ambiente.

O segundo ponto é ainda mais complexo: em nossa experiência - e no relato de diversos profissionais da área em nossa região de atuação -, as queixas que levam profissionais a procurar ajuda são, em sua maioria, bastante semelhantes. 
Ou seja: para se estabelecer uma base consistente de intervenção ou pesquisa, seria necessário não só o conhecimento em uma determinada área de estudo, mas ao menos uma referência ampliada que permita compreender múltiplas perspectivas sobre um mesmo tema.

Desta forma, nossa pesquisa se inscreve na criação de hipóteses para mapeamento do campo considerando-se esta multiplicidade de referências, e a partir desta traçar uma leitura crítica de alguns temas que nos parecem recorrentes e transversais a estes campos. Trata-se, enfim, do método que chamaremos psicanalítico: na busca entre as contraposições, paralelos e diversidade, buscamos organizaram esta produção polissêmica a partir de temas compartilhados de 'queixas' ou demandas de tratamento. Evidentemente, não esgotariam a experiência clínica ou mesmo organizacional sobre este campo, mas, ao menos, podem montar uma interlocução que permita ao profissional de saúde ampliar sua capacidade de intervir. O principal é estabelecer fronteiras claras de como delimitar suas intervenções. Com isso, a proposta dessas hipóteses aqui descritas seria a de melhor equipar os profissionais em sua formação e, simultaneamente, apoiar pesquisas futuras que busquem ampliar cada um dos temas que aqui serão tratados.

Nossas limitações também são desafiadoras. Assim como pesquisar sobre "Amor", "Verdade" ou "Amizade", falar sobre trabalho sempre será um recorte limitado em um vasto oceano de ideias. Esta pesquisa não abordou elementos essenciais como a lógica econômica atual e seus impactos no trabalho, questões de identidade e diversidade, e especialmente a dimensão política das relações de trabalho. Como afirma Nancy Fraser, há uma dimensão essencial na discussão do reconhecimento que envolve a questão da redistribuição (Fraser, 2003. P. 50). Para além do filosófico, é essencial perceber uma certa superficialidade no que a autora chama de 'culturalismo' ou 'economismo', e perceber que há inúmeras dimensões nas relações humanas que transbordam do tema do reconhecimento como uma forma de estruturação da moral. Fazendo uma analogia, mesmo que suspenso o tema do 'sofrimento' no trabalho e de sua legitimidade, há inúmeras atividades não remuneradas que têm seu papel 
estruturante ou patológico e que ainda não adquiriram a mesma visibilidade (trabalho informal, sub-trabalho, exploração de populações vulneráveis por conflitos ou migração).

Trata-se do mesmo dilema que enfrentamos ao abordar o tema do assédio moral: como afirmam Faulx, D., Delvaux, S. (2005), há um argumento político extremamente relevante de qualquer iniciativa que busque priorizar o indivíduo poderia se sobrepor à visão do todo: o enfraquecimento planejado dos sindicatos, a diluição dos coletivos do trabalho precipitada por avaliações individuais e, no limite, tratar da violência contra A ou B pode esfumaçar a importância na erradicação da violência no ambiente de trabalho para qualquer indivíduo. Enfim, são questões de imensa amplitude que irão requerer múltiplas pesquisas para aprofundar, questionar, remodelar ou eliminar estas hipóteses apresentadas.

No entanto, uma outra limitação a esta pesquisa pode ter ainda mais impacto. Se adotarmos um referencial puramente psicanalítico, a própria noção de sofrimento ou mal estar no trabalho pode ser questionada em seu cerne. Em sua abertura do livro 'La Souffrance de l'Être' (O Sofrimento do Ser), Roland Gori alerta justamente para a dimensão potencialmente perigosa de adotar qualquer perspectiva vitimizadora em relação ao que nomeia como uma maneira de "contestar o poder do Mestre" (Gaspard, 2014, P. 24). Em sua leitura, os fenômenos sobre os quais iremos pesquisar não teriam uma gênese além da possibilidade de "revolta singular pela qual se constrói a força viva dos coletivos". Estas manifestações seriam efetivamente vias de realização do ser na forma de uma 'falta-a-ser', algo que os indivíduos apropriam para expressar seu "amor à vulnerabilidade", amor à verdade, à castração.

Em oposição a correntes que se propõe a reabilitar ou re-adaptar o indivíduo ao ambiente, segundo Gori a leitura exata seria enxergar estes fenômenos como uma reação autêntica às "ideologias e ortopedias sociais" que, via adaptação, buscam transformar a sociedade em algo para o qual o "protótipo mais perfeito seria a sociedade animal. Sociedade de escravos, que reduz o humano à sua 
função de instrumento, e sua linguagem às interações de máquinas e seus sinais". Trata-se de uma crítica pungente e adequada, e um recorte essencial para observar com cautela os temas que iremos analisar. Segundo este mesmo autor:

Desde La Boétie, sabemos que o que pode se opor à servidão voluntária é a amizade, um outro nome para o amor. Na política e na psicanálise, o amor é esta via da realização da falta-a-ser pela qual se produz um furo no sistema, uma subversão do conhecimento e do saber por uma perda, perda que aprendemos a amar. Esta perda também é uma perda de tempo, condição indispensável para recuperar esta "dignidade de pensar" que ameaça nossa civilização de bons modos [moeurs]: "Em um universo no qual o sucesso está em ganhar tempo, pensar seria não apenas uma falha, seria incorrigível: perdê-lo propositalmente. [d'em faire perdre ${ }^{31}$ ]

(Gaspard, 2014, P. 25)

Para além destas limitações, esperamos que este trabalho motive também a expansão do campo das pesquisas quantitativas sobre os temas tratados; por uma escolha metodológica optamos por prescindir de entrevistas ou questionários que trouxessem uma percepção apurada da prevalência de cada um dos seis temas abordados na população metropolitana brasileira (ou mesmo um recorte em uma única organização de maior porte); são possibilidades interessantes, mas que nos parecem necessitar antes de uma fundamentação teórica que melhor determine hipóteses sobre cada um desses temas.

Por fim, a limitação mais significativa desta pesquisa pode estar na própria escolha dos seis temas trabalhados. Certamente há outros de grande relevância na literatura: Dejours menciona a importância do fator colaboração na saúde ou adoecer dos trabalhadores (Dejours, 2015). Pascale Molinier, retomando a pesquisa de Dejours, reforça os elementos do medo e tédio como os grandes perigos da contemporaneidade, para citar alguns (Molinier, 2006. Quarta-capa) A razão pela qual não os incluímos foi baseada em nossa prática clínica e aquela da qual colaboradores próximos narraram. Tais temas nos parecem

\footnotetext{
${ }^{31}$ Esta última citação - não por coincidência - é de J. F. Lyotard, 2005, em seu texto 'O pos moderno explicado a crianças' (Le postmoderne expliqué aux enfants. 1982 - 1985, Correspondences), citado por R. Gori.
} 
fundamentais, mas jamais foram citados como origem de uma demanda de tratamento, ou mesmo espontaneamente narrados em qualquer caso de nossa experiência ou mesmo da literatura pesquisada.

Esperamos que outras pesquisas vindouras trabalhem estes e outros temas, e questionem os aqui apresentados. Ainda assim, acreditamos pelos argumentos a seguir que este mapeamento do campo pode ser útil para tecer hipóteses sobre o tema que nos consome: afinal, em que se baseia tamanho mal estar no trabalho na contemporaneidade hipermoderna? 
Frente a tantos desafios de articulação entre modelos teóricos diversos, nos parece importante introduzir uma nova hipótese de abordagem para pensar o mal estar no trabalho na contemporaneidade, mesmo se tratando de um recorte bastante específico. O 'trabalho' a que nos referimos é o emprego regular (contratado ou terceirizado) em organizações com fins lucrativos, em regime frequente e remunerado, em uma metrópole de grande porte. Nossa hipótese é de que poderíamos agrupar os planos de estudo, ou temas, em três estratos, três planos que podem coincidir, se fundir ou sobrepor, especialmente quando tomamos o discurso de autores com base em suas experiências de tratamento com indivíduos de diversos segmentos da indústria.

Embora haja outros modelos similares, pera detalhar nossa metodologia de mapeamento do campo do trabalho retornaremos ao trabalho de Axel Honneth, atual diretor da Escola de Frankfurt e herdeiro de uma tradição consistente de análise filosófica e crítica. Honneth estabelece em seu texto "Padrões de Reconhecimento Intersubjetivo: Amor, Direito, Solidariedade". (Honneth, 2015. P. 155-212) uma nova forma de sistematização de sua pesquisa até ali; o título em si já serviria como base para esta hipótese em relação ao mal-estar (ou estresse) no trabalho, mas vale detalhar melhor esta distinção.

De acordo com Honneth, o jovem Hegel em seus textos de Jura postulava como 'ponto de partida' que a "reprodução da vida social se efetua sob o imperativo de um reconhecimento recíproco porque os sujeitos só podem chegar a uma autorealização prática quando aprendem a se conceber (...) como seus destinatários sociais. No entanto, uma tese relevante para a explicação disso só resulta dessa premissa geral se nela é incluído um elemento dinâmico: aquele imperativo ancorado no processo da vida social opera como uma coerção normativa, obrigando os indivíduos à deslimitação gradual do conteúdo do reconhecimento recíproco, visto que só por esses meios eles podem conferir uma expressão social às pretensões de sua subjetividade, que "sempre se regeneram"." (Honneth, 2015. P. 155 - 156) 
"As lutas moralmente motivadas de grupos sociais, sua tentativa coletiva de estabelecer institucional e culturalmente formas ampliadas de reconhecimento recíproco" (Honneth, 2015. P. 56) seriam a terceira instância, que marcaria a forma "idealista" de Hegel para determinar a esfera social mais ampla, na qual a luta pelo reconhecimento (social) se daria, um terceiro plano continente e influente aos dois primeiros já mencionados.

No volume 2 de seu 'Trabalho Vivo', Christophe Dejours também elabora brevemente uma sistematização em relação à dinâmica do reconhecimento e sua relação com a identidade. Após comentar a pesquisa de alguns autores inclusive Honneth - introduz um tópico chamado O trabalho e os três mundos". (Dejours, 2013. P. 117, trad. livre) Após discutir sobre a dinâmica do reconhecimento, sofrimento e as estratégias individuais de defesa, ele situa estes conflitos em algo que nomeia como a racionalidade subjetiva.

É nesta esfera em que posiciona uma primeira dimensão, a do trabalho como algo que se desenvolve no "mundo objetivo, no qual é submetido à validação da racionalidade cognitiva instrumental: o domínio da atividade enquanto ela se constitui como tal, e presta contas em termos da eficácia do trabalho, vis-a-vis os objetivos de produção, produtividade e qualidade" (Honneth, 2015. P. 117118).

Haveria ainda uma segunda 'dimensão', referente às "contradições inerentes à organização do trabalho, e supondo um espaço de discussão estruturada como um espaço público em que a gestão da defasagem entre o prescrito e o real é submetida a acordos entre os agentes no mundo social, digamos, à racionalidade axiológica" (Honneth, 2015. P.118).

O terceiro desses 'mundos' seria o "mundo subjetivo (aquele do reconhecimento)"; diferentemente do "mundo objetivo" e do "mundo social", o que o leva a formular a hipótese de que "na gestão de toda situação de trabalho, é mais racional levar em conta a racionalidade subjetiva das condutas do que exclui-la em nome das racionalidades teleológica e axiológica" (Honneth, 2015. P. 118). 
O autor não desenvolve esta hipótese dos três mundos para além destas considerações, mas nos parece um diálogo importante com a sistematização de Honneth (e outros) para pensar nesta tripartição em nosso campo de pesquisa.

Daí se estrutura uma metáfora interessante para pensar o campo do mal estar no trabalho: teríamos elementos intrapsíquicos, derivados da história, formação, desejos, habilidades ou debilidades de um indivíduo. No entanto, olhar somente sob esta perspectiva seria um recorte limitado; é essencial entender a interface entre este sujeito e suas condições, suas circunstâncias e contexto, as relações de trabalho em que se vê inserido. E se tais condições fossem, em si, reparadoras, ou protetoras do Eu fragilizado ou oprimido? Surge então a dimensão do interpsíquico representado por este ambiente, ou como diria Dejours, das 'regras deônticas ${ }^{32}$ ': as condições de trabalho, e, mais além, as políticas e normas implícitas e explícitas que determinam as formas de relação e, com isso, subjetivação - promovido por este ambiente. Trata-se de uma força sutil e muitas vezes insidiosa, que pode atuar como plataforma para o crescimento, andaime (ou escolho), ou mesmo força esmagadora na relação entre o indivíduo, seu ambiente de trabalho e seus agentes.

Ainda assim é essencial não ignorar uma terceira força, mais potente e modeladora das relações de trabalho que as anteriores: o impacto da sociedade (ou a influência de sua percepção pelo Eu nas identificações imaginárias do sujeito). Trata-se de algo que, de maneira simplificada, poderíamos pensar como algo que influencia na formação da 'identidade social' do indivíduo, suas expectativas, desejos e frustrações. Trata-se de um campo moldado por inúmeras forças sempre em conflito dinâmico, que se transformam de acordo com relações políticas, econômicas, culturais e biológicas.

Retomando a Honneth, este autor clarifica a lógica de sua sistematização da Estrutura das Relações Sociais de Reconhecimento, e identifica no trabalho de

\footnotetext{
32 "A atividade de deliberação que conduz à formação de regras de trabalho que são o princípio mesmo da cooperação é uma atividade deôntica". (Dejours, 2013. P. 86, trad. livre)
} 
Mead uma 'explicação empírica' de conceitos semelhantes aos trabalhados por Hegel. Além disso, acrescenta que estes dois autores não foram os únicos a adotar modelos tripartidos; talvez seja possível buscar uma organização semelhante para mapear o campo do mal estar no trabalho.

Embora não se tenha encontrado nos escritos de Mead um substituto adequado para o conceito romântico de "amor", sua teoria, como a de Hegel, desemboca também na distinção de três formas de reconhecimento recíproco: da dedicação emotiva, como a conhecemos das relações amorosas e das amizades, são diferenciados o reconhecimento jurídico e assentimento solidário como modos separados de reconhecimento. Já em Hegel são atribuídos respectivamente a esses três padrões de reciprocidade conceitos especiais de pessoa, no sentido de que a autonomia subjetiva do indivíduo aumenta também com cada etapa de respeito recíproco; mas só em Mead é dada à intuição inscrita nisso a versão sistemática de uma hipótese empírica, segundo a qual o grau de relação positiva da pessoa consigo mesma se intensifica passo a passo na sequência das três formas de reconhecimento. Os dois pensadores (...) coincidem, além disso, na tentativa de localizar os diversos modos de reconhecimento nas respectivas esferas da reprodução social: desde logo, Hegel distingue em sua filosofia política a família, a sociedade civil e o Estado; em Mead se divisa a tendência de destacar das relações primárias do outro concreto as relações jurídicas e a esfera do trabalho enquanto duas formas distintas de realização do outro generalizado.

Ora, antes de mais nada, depões a favor da sistemática inscrita nessas distintas tripartições o fato de que ela se reflete, de maneira estupenda, nas diferenciações de uma série de outros representantes da filosofia social: Max Scheler, por exemplo, distingue, com "comunidade de vida", "sociedade" e "comunidade de pessoas" fundada em solidariedade, três "formas essenciais da unidade social", que ele, não diferentemente de Hegel e Mead, põe em paralelo com etapas de desdobramento do ser da pessoa. Em Os limites da comunidade, de Plessner, encontra-se, mas em clara dependência para com a ontologia social de Scheler, uma distinção, com vista aos diversos graus de confiança intersubjetiva, em três esferas de ligações primárias, de relacionamento social e de comunidade objetiva. (...) É manifestamente óbvio distinguir formas de integração social conforme ela de realize pela via das ligações emotivas, da adjudicação de direitos ou da orientação comum por valores.

(Honneth, 2015. P. 157 - 159)

O modelo apresentado por Honneth não nos parece se propor como definitivo ou excludente dos demais, mas uma sistematização bem construída, apoiada em outras sistematizações que também chegaram a hipóteses relacionadas. O autor, inclusive, faz um imenso esforço acadêmico para criar uma costura precisa 
entre a evolução dos conceitos e, especialmente, seu valor de pré-condição para a etapa seguinte ${ }^{33}$. Assim, trata-se de uma perspectiva inspiradora para o estudo das relações do mal estar no trabalho. Não só serve como advertência para perspectivas demasiadamente estreitas e baseadas em apenas uma perspectiva, mas também abre caminho para pensar em sua faceta mais fértil: as interseções possíveis entre diferentes dimensões ou chaves interpretativas.

Há mais um elemento central deste texto de Honneth (Honneth, 2015. P. 211) que serve como inspirador para nossa hipótese. O autor estabelece um quadro de referências que esquematiza toda sua argumentação até ali. Sob o título "Estrutura das Relações Sociais do Reconhecimento", Honneth sintetiza seus argumentos na seguinte figura:

${ }^{33}$ Aqui cabe perguntar por que Honneth não abordou a teoria de Jean Piaget; seu modelo estruturalista teria sido um apoio interessante para este constructo de que uma estrutura depende das bases sólidas de seu elemento anterior (ex: a formação da noção de 'solidariedade' como condicionada pela formação dos afetos e da noção de 'outro'). (in Honneth, 2015. P. 211) 
TABELA 1: ESTRUTURA DAS RELAÇÕES SOCIAIS DE RECONHECIMENTO

\begin{tabular}{llll}
\hline $\begin{array}{l}\text { Modos de } \\
\text { Reconhecimento }\end{array}$ & Dedicação emotiva & Respeito cognitivo & Estima Social \\
\hline $\begin{array}{l}\text { Dimensões da } \\
\text { Personalidade }\end{array}$ & $\begin{array}{l}\text { Natureza carencial e } \\
\text { afetiva }\end{array}$ & Imputabilidade moral & $\begin{array}{l}\text { Capacidades e } \\
\text { propriedades }\end{array}$ \\
\hline $\begin{array}{l}\text { Formas de } \\
\text { reconhecimento }\end{array}$ & $\begin{array}{l}\text { Relações primárias } \\
\text { (amor, amizade) }\end{array}$ & Relações jurídicas (direitos) & $\begin{array}{l}\text { Comunidade de valores } \\
\text { (solidariedade) }\end{array}$ \\
\hline $\begin{array}{l}\text { Potencial } \\
\text { evolutivo }\end{array}$ & Generalização, materialização & $\begin{array}{l}\text { Individualização, } \\
\text { igualização }\end{array}$ \\
\hline $\begin{array}{l}\text { Autorrelação } \\
\text { prática }\end{array}$ & Autoconfiança & Autorrespeito & Autoestima \\
\hline $\begin{array}{l}\text { Formas de } \\
\text { desrespeito }\end{array}$ & Maus tratos e violação & Privação de direitos e exclusão & Degradação e ofensa \\
\hline $\begin{array}{l}\text { Componentes } \\
\text { ameaçados da } \\
\text { personalidade }\end{array}$ & Integridade física & Integridade social & "Honra", dignidade
\end{tabular}

Fonte: Honneth, 2015.

É inegável o valor sintético oferecido por um esquema similar; a trajetória acadêmica de Honneth o permite estabelecer estas conexões com alto grau de convicção e, mais além, de uma relação condicional entre os elementos de sua síntese. Um plano se torna condição necessária para o desenvolvimento do próximo passo, partindo do indivíduo até chegar ao espaço comum e aos códigos sociais mais amplos e compartilhados.

Nossa pesquisa tem uma ambição muito menor - falamos da contemporaneidade, contextualizada e condicionada pelas circunstâncias de um grande centro urbano em um país em desenvolvimento atravessado pelas forças sócio políticas brasileiras e influenciada fortemente por agentes econômicos externos; trata-se de um recorte que depende diretamente de experiências e referências sem pretensão alguma à universalidade. No entanto, dadas as 
devidas proporções, nos parece possível organizar alguns dos conceitos a serem trabalhados em uma matriz que segue uma lógica semelhante. Certamente, estamos diante de uma hipótese que exige mais pesquisa para se estabelecer, uma vez que suas bases até então estão fortemente apoiadas em literatura especializada, pesquisas pontuais e experiência clínica (própria, ou fruto de interações com outros profissionais).

Dada esta ressalva, apresentamos nossa própria sistematização do estado atual do campo de pesquisa sobre o mal estar ou estresse no trabalho. Trata-se certamente de uma hipótese, mas com implicações específicas que serão apresentadas a seguir.

Tabela 2: Proposta de Mapeamento De Campo Do Trabalho ContemporÂNeO

\begin{tabular}{ccc}
$\begin{array}{c}\text { Intersubjetividade } \\
\text { intrapsíquica }\end{array}$ & $\begin{array}{c}\text { Intersubjetividade } \\
\text { interpessoal }\end{array}$ & $\begin{array}{c}\text { Dimensão } \\
\text { transubjetiva }\end{array}$ \\
\hline Psicopatologia (Eu) & Psicodinâmica (Eu + outro) & Filosofia, Sociologia Clínica \\
Reconhecia (Assédio) & Expectativas Frustradas \\
\hline Autonomia & Relação Público/ Privado & Personalidades Hipermodernas \\
\hline Clínica & Organização & Pesquisa
\end{tabular}

Um ponto fundamental a ser esclarecido: diferentemente da hipótese 'evolutiva' ou 'acumulativa' do esquema apresentado por Honneth, neste caso, o conceito não se aplica. Trata-se apenas de uma tentativa semelhante de sistematização, mas que prescinde deste caráter de continuidade; a melhor forma de esclarecêlo é detalhar a fonte da primeira linha de nosso esquema, baseado em um texto intitulado "Figuras da intersubjetividade na constituição subjetiva: dimensões da alteridade", de Nelson Coelho Junior e Luís Claudio Figueiredo (Coelho Jr et al., 
2012). O primeiro aspecto a notar é a centralidade do elemento da intersubjetividade, eixo do pensamento destes autores de referência em suas obras.

Nossa apropriação é bastante livre - Coelho Jr. e Figueiredo compuseram uma sistematização que determina uma tese sólida, extensamente baseada na filosofia e fenomenologia, para traçar quatro matrizes intersubjetivas e detalhar seus autores de origem, ou 'patronos' (nas quais também se encontram mencionados Hegel, Mead, mas acompanhados de Merleau-Ponti, Husserl e outros).

As razões pela qual esta referência nos parece central são duas: a primeira é que o texto detalha estas quatro matrizes sem estabelecê-las como excludentes ou complementares. Trata-se, em suas palavras, de "um esforço no sentido de conceber e organizar quatro matrizes que favorecessem uma melhor clarificação da pluralidade de funções descritivas e operacionais do fenômeno da intersubjetividade (e) suas formas de aparição na filosofia e na psicologia". (Coelho Jr et al., 2012. P. 26). Seria impossível precisar melhor a intenção de nossa hipótese, desde que se transponha não apenas a relação 'entre sujeitos', mas acrescentando-se o campo das relações do trabalho e no trabalho. A segunda razão é que o fio central dessas análises e de suas categorias toca na relação entre 'eu' e 'outro', as dimensões de alteridade, superações da relação 'eu e outro', 'sujeito-objeto' e mesmo das armadilhas da consciência de si, ou das relações entre o eu e seu próprio mundo interno. Neste ponto, se desfaz uma barreira no estudo das relações entre o indivíduo e seu mal estar no trabalho; não estaríamos apenas falando de um fenômeno individual e dependente de suas escolhas, constituição psíquica ou contexto sociocultural. Estaríamos falando de todas estas, de uma 'imbricação' entre mundo interno e externo, e mesmo de relações dinâmicas que podem se sobrepor, influenciar umas às outras, se anular, e cuja transformação permanente é influenciada por essa articulação entre o sujeito, suas representações e as forças que o traumatizam, constituem e moldam seu campo do desejo. 
Daí veio a escolha de utilizar somente três das quatro descritas pelos autores; a dimensão da 'Intersubjetividade Traumática', (Coelho Jr et al., 2012. P. 29-31), referida ao trabalho do filósofo Emmanuel Lévinas, nos parece permanentemente presente quando tratamos do mal estar ou estresse no trabalho. Esse outro que "me precede e me traumatiza e com isso me constitui" (Coelho Jr et al., P. 29) já seria em si uma representação importante da dimensão das relações de trabalho (evidentemente, no trabalho de Coelho Jr. e Figueiredo, sua argumentação vai muito mais além do que apenas a dimensão do trabalho; trata-se da própria constituição do eu no mundo). Trata-se fundamentalmente das 'convivências e transformações' - e transformações que requerem e implicam em trabalho inevitáveis desta convivência com aquilo que difere de mim, e que poderia mesmo me fazer um outro. Neste sentido, me parecem ampliar e mesmo transcender a argumentação de Honneth, no sentido em que concebem a alteridade como "traumática, exige trabalho e esforço em processos permanentes de inadaptação entre eu e outro". (Coelho Jr et al., P. 30)

Voltando ao esquema e à nossa apropriação de suas categorias, a primeira dimensão apresentada é a intersubjetividade intrapsíquica. De forma resumida, trata-se da dimensão das relações no plano dos objetos internos, fantasias, objetos interiorizados ou incorporados (na terminologia freudiana clássica). É neste plano que situaremos dois temas bastante trabalhados por autores do campo do mal estar ou estresse no trabalho: Reconhecimento e Autonomia. Uma primeira reação possível seria imaginar que esses dois termos inicialmente apontam para uma relação essencialmente dual. O reconhecimento é em sua origem a base da relação eu-outro, assim como a autonomia é a autonomia do eu para com os limites ou constrangimentos externos. No entanto, nossa pesquisa se dá no campo do mal estar ou do estresse; desta forma, é essencial marcar que ambos elementos viriam sim influenciados por elementos externos, ou melhor, agentes externos. Entretanto, a experiência do 'sofrimento' se daria justamente em um descompasso entre esses agentes externos e as dinâmicas e sutilezas próprias da constituição do eu e da identidade pessoal frente a seus interlocutores internos. Por exemplo: se meu trabalho se torna angustiante pela 
ausência de uma validação de um superior ou colega, indica imediatamente uma potencial fragilidade de minha própria relação com esse trabalho e minha estima em relação a ele; a falta marcada pela ausência de reconhecimento interpreta a própria falta em mim. Veremos adiante que Dejours posiciona o reconhecimento em uma outra perspectiva mais fértil, a de uma repatriação dos esforços e angústias investidos no trabalho na valorização do trabalhador. No entanto, a dimensão de vulnerabilidade do eu nos parece inevitavelmente ligado à experiência existencial única deste eu e de sua forma de se constituir no mundo. Daí o fato de o reconhecimento ser algo tão particular - cada sujeito se percebe reconhecido por 'recompensas' totalmente pessoais, e ligadas à sua identidade, suas carências e aspirações.

Em um segundo plano, teríamos a dimensão da intersubjetividade interpessoal, aquelas construídas "nas interações entre organismos e sujeitos individuais" (Coelho Jr et al., P. 31). Trata-se do campo dos gestos, das trocas e interações, dos significados compartilhados e das mediações do outro às minhas respostas. É interessante notar que Coelho Jr. e Figueiredo posicionam tanto o trabalho de Hegel como o de Mead nesta dimensão; desta forma, se fôssemos seguir rigorosamente a matriz estabelecida por Honneth, seria mais adequado posicionar nesta dimensão o campo do reconhecimento. No entanto, em se tratando da dimensão do trabalho e, especialmente, do estresse no trabalho, este campo nos parece muito mais próximo daquilo que é objeto primordial da Psicodinâmica do Trabalho segundo Dejours, daquilo que define como as 'relações deônticas', os espaços - existentes ou faltantes - nos quais os trabalhadores refletem sobre as regras mesmas que irão reger seu ambiente de trabalho. Trata-se de um 'entre' que promove o reconhecimento e validação, mas que contém uma dimensão inescapável do 'em torno', das dinâmicas explícitas ou tácitas das relações de trabalho. É neste campo que nos parece incidirem duas temáticas essenciais de nossa pesquisa; a violência no ambiente de trabalho (e todas suas variantes, em especial o assédio) e a relação entre público e privado. Se este último parecer menos evidente, basta lembrar que em todos os casos em que organizações adotam práticas invasivas em relação à 
privacidade ou tempo privado dos seus trabalhadores (por exemplo, exigindo trabalho realizado no tempo de descanso, ou controlando hábitos pessoais de seus funcionários), isso depende necessariamente de uma aceitação ativa ou passiva desta coletividade. Veremos este elemento mais adiante quando explorarmos a questão do assédio, mas autores como Faulx e Delvaux (2009) já alertavam para o fato de que o aumento das queixas de assédio na contemporaneidade não poderia ser analisado sem considerar a perda de poder gradual dos Sindicatos laborais desde a década de 1970. Em suma, mesmo se tratando de fenômenos que se desenvolvem predominantemente em díades (chefe-subordinado, por exemplo), eles apontam necessariamente para uma ausência ou conivência da organização a estas práticas estressoras.

Por fim, temos a dimensão mais abrangente - do ponto de vista sociológico ou cultural. A intersubjetividade transubjetiva é aquele "continente engolfante", "um solo de acolhimento e sustentação" (Coelho Jr et al., P. 26), na qual posicionamos este campo que corresponde no limite na concepção própria do trabalho para a contemporaneidade. Trata-se deste campo 'oceânico', sociocultural e de difícil delimitação que só é possível tangibilizar em um tempo e contexto específico. Em nossa hipótese, consideramos a realidade de trabalho em empresas privadas na contemporaneidade, ao menos em grandes centros urbanos como São Paulo (ou outras metrópoles semelhantes em termos de porte, mercado de trabalho, índice de desenvolvimento, etc.); possivelmente, encontraríamos elementos muito diferentes em outras épocas, regiões e contextos. Entretanto, considerando o nosso ambiente, haveriam dois fatores que influenciam uma ampla maioria dos indivíduos que experimentam mal estar ou estresse no trabalho. Uma delas é um descompasso entre expectativas e as oportunidades efetivas encontradas no campo do trabalho; isso poderia se relacionar com os estudos sobre o mercado de consumo de autores como Lipovetsky e outros, mas que encontram sua melhor expressão em trabalhos como os de Miya Tokumitsu, em seu aspecto de denúncia de um discurso malicioso de 'amor ao trabalho' ('faça o que você ama') que encobre dinâmicas exploratórias nas quais as organizações são desresponsabilizadas por criar ambientes nocivos e 
geradores de estresse em nome de um falso propósito. A isso se soma um outro fenômeno que parece específico, mas seus efeitos atingem uma plenitude de jovens ingressantes no mercado de trabalho. Autores como Nicole Aubert, Robert Castel e outros o nomeiam como 'personalidades hipermodernas'. Tratase de um fenômeno de polarização, no qual mesmo que não englobe a totalidade dos trabalhadores, produz um grande número de indivíduos que se sustentam por um 'excesso' individualista (expectativas infladas sobre si, ausência de vínculo, 'narcinismo ${ }^{34}$ e abuso de substâncias que promovam esta ampliação permanente de si) e, em oposição, uma horda de indivíduos do 'vazio' (já de início condenados a uma imagem pessoal de ruína, fracasso e exclusão). Aqui nos parece o campo privilegiado das sociologias - em particular, as sociologias clínicas - mas que não deixam de englobar os fenômenos de massa e campo privilegiado para pesquisar elementos transgeracionais, coletivos ou culturais. Trata-se de um campo de imenso valor de pesquisa, mas que transcende os limites da clínica; o sujeito de estudo é o humano, ou o zeitgeitst específico daquele grupo, impossível de apreender no caso a caso, mas cujos traços são impossíveis de ignorar.

Em resumo, nossa proposta é de que as intervenções clínicas, organizacionais ou populacionais (como a pesquisa) não podem deixar de considerar as dinâmicas particulares de cada uma destas dimensões, e, simultaneamente, entender cada parte como um universo em si. O elemento que ancora uma intervenção clínica, por exemplo, sempre será o discurso daquele sujeito; no entanto, escutar apenas esta narrativa sem contextualizá-la em sua

\footnotetext{
${ }^{34}$ Este termo foi criado pelo psicanalista Christian Demoulin e citado pela psicanalista francesa Lise Gaignard, introduzindo o conceito como o 'sujeito narcínico'. "O único ideal que vale para alguns, ao lado do gozo cínico, é aquele da realização narcísica. ("A psicanálise terapêutica", 2001) O novo sujeito do consumo e da mentira é chamado de "narcínico", e poderia ser pensado como o sujeito mais adaptado aos novos modos de produção". (in Dejours, 2007. P. 171) Com a reorganização do trabalho criaram-se condições potencialmente dolorosas em relação aos valores do trabalho bem feito, o sentido da responsabilidade e a ética profissional. A obrigação de fazer mal o trabalho, de ter que dá-lo como terminado ou mentir é uma fonte frequente de sofrimento no trabalho: está presente na indústria, nos serviços, na administração. Nos parece que desta forma, o psiquismo se protegeria elaborando uma moral própria e paralela, propensa a se proteger (de modo narcísico) e, simultaneamente, considerar-se acima dos próprios malfeitos, capaz de cometer e julgar o próprio delito. Daí o elemento do cinismo, e a soma tóxica de ambos.
} 
complexidade das relações ou sem vê-la inserida em uma cultura e um momento histórico específico seria reduzi-la em sua complexidade. É fundamental perceber esta dinâmica como uma interação entre planos diferentes e singulares, orientados a partir do mal estar de cada sujeito em suas condições de trabalho.

Em termos de pesquisa, evidentemente trata-se de um campo de tamanho dinamismo que qualquer hipótese se encontrará inevitavelmente fadada a um contexto e um caráter temporário. No entanto, mapeá-lo pode ser essencial para introduzir uma perspectiva desta complexidade que pode, no limite, conduzir a outras pesquisas mais delimitadas, específicas e relevantes para nosso objetivo fim: trazer à tona a importância de uma perspectiva mais integradora, menos unívoca e definitivamente flexível em intervenções ou pesquisa ligadas ao campo da investigação e intervenção sobre o mal estar e estresse no trabalho. 
No grego antigo, o verbo ballo $(\beta \alpha \lambda \lambda \omega)$ significa jogar, lançar. O $\sigma v \mu \beta 0 \lambda \lambda \omega$ é um oximoro que significa, por sua vez, a variação, a dispersão e a reaproximação. O polo forte desse par é o movimento centrípeto. Na prática esse verbo, ballo, significava: colocar em conjunto o que foi disperso, se reconhecer por um objeto que atesta um antigo laço, coletar dinheiro, recolocar em comum, reunir. Pode significar ainda colocar em jogo uma relação de reciprocidade: trocar gestos de hospitalidade. A quintessência do $\sigma u \mu \beta o \lambda \lambda \omega$ é um registro do memorável que passa pelo retorno do que foi enviado por um outro, ou o reconhecimento de um antigo laço. (...) O leitor já entendeu que o símbolo, o sum-bolom $(\sigma v \mu \beta \mathrm{o} \lambda v)$, em seu primeiro sentido é o meio, a bolinha, a ficha que ao ser passada adiante permite criar os laços simbólicos na cultura humana, dito de outra forma, os laços de reconhecimento no respeito da singularidade de cada um dos participantes. Mesmo se a piores causas se alardeiem prontamente nos desfiles do apelo simbólico, a essência do simbólico está do lado da complexidade, da memória, do trabalho da cultura, e, especialmente, do desenvolvimento humano. E a esse respeito, há uma conivência com o trabalho em sua dimensão de construção do mundo humano. Ao inverso, se a dispersão for sem volta, se não nos entendermos na cidade ou fora dela, passamos então a ser submetidos à lei do diabolos ( $\delta 1 \alpha \beta \mathrm{o} \lambda \mathrm{o} \zeta)$, o que está do lado da dispersão sem volta, da perda, do não renovável. É o que desune, que inspira o ódio ou a inveja, o que calunia.

(Doray, 2011. P. 208-209)

Já vimos o trabalho de Honneth o quanto mapear a dinâmica do Reconhecimento é uma tarefa extremamente complexa; um debate mais completo envolveria não apenas retornar ao conceito em si, mas situa-lo em relação à obra de praticamente todos os autores que estudaram a consciência, personalidade, dinâmicas intrapessoais, grupos, e assim por diante. Como no também citado texto de Bernard Doray, a dinâmica do reconhecimento atravessa desde as mais simples interações até nossa relação com os símbolos, a sociedade e mesmo a cultura. Nesta mesma linha, Dufour aponta que uma das maiores características da pós modernidade seria justamente a erosão da habilidade humana de simbolizar; na luta contra símbolos identitários como 'família', 'religião' ou 'governo', o sujeito pós moderno teria sacrificado sua própria habilidade de simbolizar. Dito de outra forma: "Uma vez que todos os garantidores simbólicos de trocas entre humanos começam a desaparecer, a condição humana em si 
começa a se transformar". (Dufour, 2008. P. 5, trad. livre) Trata-se, assim, de uma mudança da dinâmica social que traz um impacto direto à esfera do reconhecimento; conforme Doray, se a relação com o 'simbolon' torna-se nublada, estaríamos no domínio do 'diabolon', da dispersão, da ruptura. Se o reconhecimento é algo que depende da conexão, do vínculo, da relação do outro como outro, a transformação do trabalhador em 'custo' - ou em 'preço', seria um movimento de ruptura com a dignidade, algo que Axel Honneth estabelece como condição essencial ao reconhecimento, como veremos adiante.

Não à toa, uma das demandas principais na busca de ajuda quanto ao estresse ou "sofrimento no trabalho" é falta de reconhecimento, especialmente traduzido como sensação de menos-valia, dissonâncias e promessas quebradas. Entretanto, é impossível fazer mesmo um recorte quanto ao tema do reconhecimento na esfera do trabalho sem uma introdução a alguns fios condutores da evolução do conceito nas ciências humanas.

Este termo traz uma ambiguidade em sua origem que pode ser interessante explorar. As fontes clássicas o remetem ao 'conhecer', derivado do '-gno-' com suas variações em Grego e Latim, como 'gnosis' ou 'noscere - 'familiarizar-se, buscar informações'35. Entretanto, tanto na teologia quanto na filosofia haveria uma segunda opção que seria derivada não de 'noscere', mas 'nascor' (nascer). Segundo Jean-Luc Berlet (2008) esta possibilidade traria o termo 'conhecer' (conaissance) da variação de conascere, 'nascer junto'. O conhecer estria ligado a um 'nascer no contato com o saber ou com o outro'. Não por acaso, o reconhecer seria o ato de lembrar-se (ou conhecer novamente) mas não apenas isso; reconhecer o outro também significaria tornar visível ao outro a percepção do seu valor.

\footnotetext{
${ }^{35}$ Só no Dicionário Houaiss da Língua Portuguesa temos 22 sentidos possíveis de 'conhecer' e 19 de 'conhecido', para exemplificar como esse termo é de extrema complexidade. 'Reconhecer tem 11 sentidos diferentes. O interessante é ver que sua etimologia original para esses autores era essencialmente militar: 'inspecionar, verificar, fazer a revista de'. É em 1301 que surge o uso deste termo no sentido de "aceitar", e a partir do Século XV traz também a ideia de 'gratidão" (Houaiss, 2001).
} 
Há uma ambiguidade se pensarmos nestes dois caminhos; o reconhecer por ser tanto alto ligado a uma temporalidade ou à memória, enquanto o outro sentido dispensa esta temporalidade para situar-se no ato de apreender o outro em seu valor e, ao fazê-lo, transformar a si e ao outro, na acepção em que nascemos novamente e fazemos algo nascer ao reconhecer este algo como diferente de si. Berlet (2008) esclarece isso ao mencionar que o conhecer exigiria entrar em "osmose" com esse objeto. Berlet menciona que para Nietsche, por exemplo, reconhecer seria o "ato de reconhecer a dignidade do objeto percebido e evitar assim sua "violação racionalista". "Com Nietsche, estaríamos no registro moral do reconhecimento tomado ao sentido da gratidão" (2008).

Para Berlet isto nos levaria de volta à noção platônica da reminiscência na teoria das ideias, na medida em que para este filósofo qualquer conhecimento seria, assim, reconhecimento, na medida em que o Céu das Ideias já teria em si este conceito que será apropriado via (re) conhecimento. Para Platão (Berlet, 2008), o reconhecimento seria uma saudação filosófica que permite à nossa alma reentrar através de sua conversão ao princípio espiritual.

Axel Honneth, diretor da Escola de Frankfurt e herdeiro de Adorno, Horkheimer e Habermas, baseou suas principais ideias neste princípio da luta por reconhecimento. Para este autor, o conceito passou por uma série de movimentos de tese - antítese ao longo da filosofia. Partindo dos escritos de G.H. Hegel, em especial seus estudos de Jena, passamos de uma filosofia clássica na qual a autorealização humana seria alcançada na vida política e na comunidade para uma filosofia social moderna definida fundamentalmente como uma relação de luta por autoconservação (Honneth, 2015. P. 31). Este movimento foi bastante influenciado pelo trabalho de Maquiavel (Honneth, 2015. P. 32), que embora trabalhasse com elementos da filosofia clássica romana como virtu e fortuna, desliga-se das perspectivas antropológicas anteriores de comunidade e sociedade e introduz o conceito de homem como um ser egocêntrico, atento somente ao proveito próprio. "Para Maquiavel, o ponto de referência supremo de todos os seus estudos históricos é sempre a questão de saber de que maneira o conflito ininterrupto entre os homens pode ser habilmente influenciado em favor 
dos detentores do poder; (...) o campo da ação social consiste em uma luta permanente dos sujeitos pela conservação de sua identidade física" (Honneth, 2015. P. 33) Hobbes será outro filósofo a ampliar esse panorama ao introduzir a validade da soberania do Estado justamente para intervir nesta potencialidade da guerra de 'todos contra todos'.

É com Hegel que esses elementos verão uma nova virada; segundo Honneth (2015, P. 37 - 39), em 1802 Hegel irá iniciar sua trajetória de diferenciação com esse modelo egocêntrico ao discutir as teorias morais de Kant, a leitura de Platão e Aristóteles e ao discutir sua teoria do direito natural reintroduzir à luz a intersubjetividade da vida pública. Embora parta de uma perspectiva inicial do humano como essencialmente egocêntrico e "aético", haveria uma disposição para reprimir em si estes impulsos em busca de uma ética que o permita constituir uma comunidade. É desta forma que Hegel chega a um conceito de 'liberdade universal e individual' que recupera as ideias centrais da pólis como coletividade ideal, uma que "deve implicar que a vida pública teria que ser considerada não [como] o resultado de uma restrição reciprocados espaços privados da liberdade, mas, inversamente, a possibilidade da realização da liberdade de todos os indivíduos em particular" (Honneth, 2015. P. 41). Para Hegel, seria importante também marcar a centralidade dos "costumes" (Sitte), no sentido em que "nem as leis prescritas pelo Estado nem as convicções morais dos sujeitos isolados, mas só os comportamentos praticados na esfera intersubjetiva são capazes de fornecer uma base sólida à liberdade ampliada.

Essas ideias abrem para Hegel um novo problema ao descrever os conteúdos normativos da socialização: "só quando o curso histórico-universal do "vir-a-ser da eticidade" é concebido como um entrelaçamento de socialização e individuação pode-se aceitar que seu resultado seria também uma forma de sociedade que encontraria sua coesão orgânica no reconhecimento intersubjetivo da particularidade de todos os indivíduos" (Honneth, 2015. P. 45). Para Hegel, "as relações éticas de uma sociedade representam (...) as formas de uma intersubjetividade prática na qual o vínculo complementário e, com isso, a comunidade necessária dos sujeitos contrapondo-se entre si são assegurados 
por um movimento de reconhecimento. A estrutura de uma tal relação de reconhecimento recíproco é, para Hegel, em todos os casos, a mesma: na medida em que se sabe reconhecido por um outro sujeito em algumas de suas capacidades e propriedades e nisso está reconciliado com ele, um sujeito sempre virá a conhecer, ao mesmo tempo, as partes de sua identidade inconfundível e, desse modo, também estará contraposto ao outro novamente como um particular" (Honneth, 2015. P. 46-47) O reconhecimento mútuo não se dá fora de uma dimensão de conflito, mas é o que possibilita ultrapassar a dimensão da luta pela autoconservacão e abre espaço para a ética, assim como as noções de 'dignidade' e 'honra', este último como a atitude em relação a si pela qual um indivíduo vem a ser um "todo e pessoal" (Honneth, 2015. P. 55).

Para Honneth, estes conceitos evoluem e em 1804 o termo reconhecimento "refere-se àquele passo cognitivo que uma consciência já constituída "idealmente" em totalidade efetua no momento em que ela "se reconhece como a si mesma em uma outra totalidade, em uma outra consciência" (Honneth, A. 2015. P. 62-63). É na manifestação do meu agir em minha totalidade e no encontro com uma outra totalidade que me reconheço, se respeitada.

É importante marcar que até então estamos discutindo o reconhecimento em sua potencialidade maior, a formação da consciência. Honneth é bastante preciso em marcar este elemento como um 'passo cognitivo' na experiência humana:

[O] termo "reconhecimento" refere-se àquele passo cognitivo que uma consciência já constituída idealmente" em totalidade efetua no momento em que "se reconhece como a si mesmo em uma outra totalidade, em uma outra consciência"; e há de ocorrer um conflito ou uma luta nessa experiência do reconhecer-se-no-outro, porque só através da violação recíproca de suas pretensões subjetivas os indivíduos podem adquirir um saber sobre se o outro também se reconhece neles como uma "totalidade": "Mas se eu não posso saber se minha totalidade, como uma consciência, será esta totalidade sendo-para-si, se ela é reconhecida, respeitada, senão pela manifestação do agir do outro contra a minha totalidade, e ao mesmo tempo o outro tem que manifestar-se a mim como uma totalidade, tanto quanto eu a ele".

(Honneth, 2003. P. 63) 
Podemos avançar na importância do reconhecimento, mas antes podemos citar uma passagem na qual o próprio autor resume o cerne de sua teoria e introduz um tema que retomaremos em seguida: a importância de uma análise tripartida dos fenômenos de reconhecimento, que irá encontrar e nossa hipótese um eco na leitura do mal estar no trabalho. Para este autor, só seria possível enxergar a luta pelo reconhecimento se olharmos simultânea e separadamente para três esferas distintas do fenômeno.

(...) Cada uma das três formas de relação que delineei é distinta por princípios normativos internos que estabelecem diferentes modos de reconhecimento mútuo. O "Amor" (a ideia central de relações íntimas), o princípio da igualdade (a norma das relações jurídicas) e o princípio da realização (o padrão da hierarquia social) representam perspectivas normativas em referência às quais indivíduos podem razoavelmente argumentar que formas existentes de reconhecimento são inadequadas ou insuficientes e devem ser expandidas. A esse respeito, ao contrário de outras relações sociais estruturalmente produzidas na nova sociedade, as três esferas do reconhecimento formam modelos normativos singulares de interação, no sentido que não podem ser praticados a não ser que seus fundamentos intrínsecos sejam respeitados. Finalmente, uma nova preocupação envolve o fato que somente relações sociais que exijam uma atitude de reconhecimento mútuo contribuem para o desenvolvimento de uma forma positiva de apreciação de $\mathrm{si}^{36}$. Somente ao participar em interações na quais normas pré-estabelecidas incluem a orientação recíproca a princípios específicos de reconhecimento é que indivíduos podem experimentar a valorização persistente por outras pessoas de suas capacidades individuais."

(Honneth, 2003. P. 63)

Estas reflexões são um passo essencial para determinar o campo em que o reconhecimento pode ser constitutivo na formação de um 'Eu' ou uma consciência madura. Contudo, como transpor esse conceito para a esfera do mal-estar no campo do trabalho?

Como citado anteriormente, Eric Hobsbawm estabeleceu o elemento histórico do reconhecimento ligado à estima, ao orgulho do próprio fazer. Dejours ecoa essa concepção, e, uma passagem que traz o conceito da invenção e sua importância para a estima, satisfação e, principalmente, o mal estar promovido por sua ausência.

36 "No original, "a positive self-relation." 
A validação da invenção passa por um reconhecimento que atua em dois registros: reconhecimento pela hierarquia de um lado, e reconhecimento pelos pares de outro lado. Esses dois modos de reconhecimento não são equivalentes. O primeiro é um reconhecimento de utilidade, o segundo é um reconhecimento de competência [no original, savoir-faire], de uma inteligência, de talento pessoal, de originalidade, até mesmo de beleza. Só os pares estão em condição de avaliar plenamente a qualidade da inovação técnica. Mesmo se tratando de um fazer [faire] que seja reconhecido pelos pares (...) é no registro do ser que o sujeito o capitaliza. É assim que o reconhecimento aporta um benefício no registro da identidade, ou seja, é a via pela qual esse trabalhador é um sujeito único, diferente de qualquer outro.

(Dejours, 2016. P. 92. Trad. livre)

Há ainda outra passagem, anterior em sua obra, que também explica a passagem do ato de reconhecimento à estima pessoal. Em um trecho do segundo volume de seu "Trabalho Vivo", Dejours apresenta um excerto chamado 'Reconhecimento e trabalho'. Ali, o autor faz uma sistematização precisa sobre sua leitura do fenômeno do reconhecimento no trabalho, cuja falta é "um dos temas recorrentes do universo do trabalho". (Dejours, 2013. P. 112, trad. livre) Ao mencionar o potencial nocivo da percepção de falta de retribuição pelo trabalho realizado, Dejours o posiciona da seguinte forma: "A análise psicodinâmica sugere que a retribuição esperada pelo sujeito é fundamentalmente de natureza simbólica. Ela envolve uma forma específica, facilmente comprovada por estudos empíricos: trata-se do reconhecimento. Reconhecimento em suas duas dimensões: Reconhecimento no sentido da constatação ${ }^{37}(\ldots)$, reconhecer a realidade que constitui a contribuição do sujeito à organização do trabalho. (...) Reconhecimento no sentido da gratidão pela contribuição dos trabalhadores à organização do trabalho". (Dejours, 2013. P. 112 - 113, trad. livre) A este segundo tipo (gratidão), seriam acrescentados ou contidos dois juízos específicos: o juízo de utilidade (reconhecimento da qualidade ou valor pelos superiores, subordinados e clientes) e o juízo de beleza

\footnotetext{
${ }^{37}$ No original, 'constat': pode server tanto para o ato de constatar (dar-se-conta de algo, afirmar sua existência), como uma atestação de validade (como fazer um auto, um laudo, certificar algo).
} 
(admiração dos pares, colegas e outros profissionais especialistas na mesma atividade).

\begin{abstract}
A validação [social] da invenção passa por um reconhecimento que atua em dois registros: reconhecimento pela hierarquia de um lado, e reconhecimento pelos pares por outro. Esses dois modos de reconhecimento não são equivalentes. O primeiro é um reconhecimento da utilidade, o segundo é um reconhecimento do saber-fazer, da inteligência, do talento pessoal, da originalidade na forma da beleza. Somente os pares têm condições de avaliar plenamente a qualidade da inovação técnica. Mesmo tratando-se de um fazer o que essencialmente é reconhecido pelos pares (coletivo ou comunidade à qual pertence), é no registro do ser que o sujeito o capitaliza. Assim, o reconhecimento aporta em si um benefício no registro da identidade, ou seja, nesta razão que torna aquele trabalhador um sujeito único e diferente de todos os outros.
\end{abstract}

Em outras palavras, a passagem necessária para a validação social conduz a fazer da sublimação um processo social e historicamente situado para além das diferenças notáveis, não somente em função das relações sociais de produção, mas também em função das relações sociais de reprodução (Hirata e Kergoat, 1988). É por meio do reconhecimento que o processo de mudança do objeto da pulsão atua, se tomamos como base a teoria da sublimação.

(Dejours, 2016. P92. Trad livre)

Esta passagem de Dejours reforça justamente uma visão complementar do reconhecimento que vai além da 'formação da consciência', e que trata da relação entre pares, ou entre semelhantes, bastante particular à dimensão do trabalho. Entre os autores que reforçam essa relação entre o reconhecimento no trabalho, especialmente no registro do orgulho, está Eric J. Hobsbawm em seu "Os Trabalhadores: Estudos sobre a História do Operariado." Nesta obra, a dinâmica do reconhecimento aparece como central nas mudanças graduais no sistema de remuneração dos 'Colarinhos Azuis', os operários ingleses; além das recompensas materiais, "o salário justo por um dia justo de trabalho", os trabalhadores tinham forte apego ao orgulho de perceber um trabalho bem feito. Afora os trabalhadores sem qualificação - e potencialmente mal pagos - a massa dos operários qualificados tinha um forte senso de satisfação quando viam seu trabalho cumprido com qualidade, algo que pode ser pensado pelo reconhecimento entre iguais. Isso funcionava como um grande regulador e - mais importante - fora das relações com os empregadores e mesmo os sindicatos. A reação dos colegas ao se ofenderem com um trabalho mal feito era um dos 
principais influenciadores no comportamento, especialmente por ferir o orgulho do grupo. (Hobsbawm, 2015. P. 407-408)

Neste trecho é possível ver em Dejours a mesma leitura de Hobsbawm sobre o reconhecimento e este elemento do reconhecimento pelos pares, que poderia ser manifesto como orgulho, ou estima. No entanto, o foco principal em seus trabalhos é destacar a natureza do reconhecimento em seu efeito na subjetividade, algo que nomeia como a 'psicodinâmica do reconhecimento'.

Reconhecer a existência da "psicodinâmica do reconhecimento" permite compreender o importante papel que joga no destino do sofrimento no trabalho e a possibilidade de transformar o sofrimento em prazer."

Porque, efetivamente, desse reconhecimento depende o sentido do sofrimento. Quando a qualidade do meu trabalho é reconhecida, o que adquire sentido são meus esforços, minhas angústias, minhas dúvidas, minhas decepções e meus desalentos. Todo esse sofrimento não foi em vão e não só contribuiu para a organização do trabalho, mas que, ao contrário, fez de mim um sujeito diferente daquele que era antes do reconhecimento. O sujeito pode transferir esse reconhecimento do trabalho para o registro da construção de sua identidade. E o trabalho se inscreve assim na dinâmica da autorealização. A identidade constitui a armadura da saúde mental.

(Dejours, 2013)

Há outra passagem que também exemplifica esta dinâmica, em especial naquilo que tange à retribuição simbólica do trabalho.

O reconhecimento como retribuição simbólica pela contribuição não repousa na pessoa. Repousa no trabalho, a qualidade do trabalho. $\mathrm{O}$ juízo do reconhecimento recai sobre o fazer. É somente em um segundo tempo que o sujeito pode, eventualmente, repatriar esse juízo do registro do fazer ao registro do ser. (...) O reconhecimento pode transformar o sofrimento em prazer. É o reconhecimento que dá ao trabalho seu sentido subjetivo.

Trabalhar jamais se trata unicamente de produzir, mas também transformar a si. (...) [graças a uma perspectiva clínica sabemos que] o reconhecimento pelo outro no registro do amor é o que nos completa $^{38}$. É então através dessa estratégia do reconhecimento no trabalho que a identidade é mantida e provada. Muitas pessoas conservam seu equilíbrio psicológico essencialmente graças à sua relação subjetiva e social no trabalho.

(Dejours 2007, P. 22 - 23)

\footnotetext{
${ }^{38}$ No original, o termo central é dessa frase é 'déffaillante', faltante. Daí nossa escolha por traduzir como 'completar, o que supre a falta.
} 
O trabalho pode ser assim pensado como fenômeno eminentemente humano, diferente de qualquer atividade animal justamente por essa dimensão da intenção e do reconhecimento, tão fértil para promover realização como para promover frustração e mal estar. Em uma sociedade que cada vez mais se aproxima da definição citada por Hannah Arendt de 'sociedade laboral', estudar o trabalho é estudar a dinâmica do reconhecimento e sua influência nas interações que compõe o laço social e

Para concluir, podemos trazer uma nota de alerta no campo do reconhecimento. Gilles Lipovetsky, em seu texto "Tempos Modernos" (Modern times, 2005) alerta para o risco, em indivíduos com personalidades hipermodernas, de uma busca por um excesso de reconhecimento. Característica central dessas personalidades em busca do excesso, do 'hiper', também haveria em parte da força de trabalho contemporânea uma demanda por um 'Hiper-reconhecimento'.

[Se o] hiper-individualismo não pode ser separado da consagração dos prazeres privados e mérito individual, somos obrigados a notar que é igualmente inseparável de um aumento intenso de demandas por reconhecimento público, e também de demandas de culturas diferentes por respeito igualitário. Deixou de ser suficiente nos reconhecer pelo que fazemos, ou como cidadãos livres e iguais a quaisquer outro: trata-se de ser reconhecido pelo que somos, em nossa especificidade como parte de uma comunidade e uma história, pela qual nos distinguimos de outros grupos. Isso é prova, entre outras coisas, que a modernidade [...] não está exaurida pela enxurrada solipsista de apetite pelo consumo: de fato, traz dentro de si um alargamento do ideal de respeito igualitário, um desejo de hiperreconhecimento no qual, rejeitando toda forma de crítica, depreciação ou senso de inferioridade que uma pessoa pudesse sofrer, exige o reconhecimento do outro como igual em sua diferença". 
Toda filosofia parece sugerir que a autonomia é a coisa mais difícil no mundo de se atingir, e que atingi-la é um trabalho de vida inteira.

(Dufour, 2008. P. 15. Trad. Livre.)

Em julho de 2017, Daniéle Linhart contribuiu com o periódico Le Monde Diplomatique Brasil com um texto chamado "Um assalariado sem submissão é possível". Neste texto, ela desenha um panorama duro - mas bastante preciso sobre algumas das fontes de mal estar da contemporaneidade. Neste texto, a autora aborda especificamente a crise de profissionais de mercados recentemente inaugurados como motoristas de Uber e outros profissionais que optam por regimes inéditos de trabalho até alguns anos atrás; profissionais que gozam de uma condição de trabalho que, aparentemente, se beneficia de autonomia, independência, conforto nas escolhas de sua própria rotina. No entanto, Linhart ressalta justamente uma tendência ao oposto: profissionais destas categorias lutando pela sua integração a formas mais convencionais de trabalho.

Para ter direito ao estatuto de empregado, na iniciativa privada, e de funcionário público, o trabalhador deve comprometer-se a atuar no contexto bastante específico de uma subordinação permanente, isto é, da obediência aos representantes da empresa ou órgão, que está no cerne do contrato salarial. Mas, por causa dos direitos a ele relacionados, o estatuto de subordinado parece vantajoso e até desejável, como mostra o citado exemplo dos motoristas ou o dos trabalhadores que se mobilizam para não serem expulsos, empreendendo longas lutas, às vezes muito violentas, contra os planos de demissões. (...)

\footnotetext{
${ }^{39}$ Não só a metáfora do Pinocchio nos parece ideal para ilustrar a busca contemporânea por um 'propósito' via trabalho, mas traz mais do que inicialmente aparenta. Seu surgimento foi em 1883, pela obra do escritor italiano Carlo Collodi; no original 'As Aventuras de Pinocchio', Collodi buscava criar um conto moral para alertar aos camponeses italianos ignorantes sobre os riscos de se aventurar no mundo de maneira ingênua. Em uma época de escassez de trabalho qualificado em função da intensificação da Revolução Industrial, muitos trabalhadores jovens emigravam em busca de uma vida melhor. Não à toa, no original de Collodi, Pinocchio é um boneco travesso, por vezes cruel e ingrato, que sonha com a possibilidade de virar um menino de verdade. No final do conto, seus inimigos Raposa e Gato o enforcam em uma árvore, e o boneco termina morto, balançando ao vento. Embora o conto de Collodi tenha o elemento do crescimento de seu nariz quando mentia, sua transformação em um menino só foi acrescentada anos mais tarde. (Wikipedia, acesso em 10/01/19)
} 
No entanto, não faz muito tempo, essa condição de empregado era rejeitada por quem sonhava com uma sociedade do trabalho emancipadora, na qual os trabalhadores não precisariam submeterse à exploração e à alienação. Hoje considerada uma espécie de fatalidade, tal condição justifica o sacrifício necessário para assegurar um mínimo de garantias sobre o futuro: um salário, acesso aos cuidados de saúde, auxílio em caso de desemprego, além da possibilidade de uma inserção social e cidadã na sociedade, bem como a participação em uma comunidade de trabalho que faça algum sentido. A subordinação, essa forma de renúncia de si mesmo, tornou-se mais que nunca um investimento, que deveria proteger contra a precariedade material e a perda de autoestima.

(Linhart, 2017. P. 16. Trad. livre)

Linhart estabelece uma linha fina que conduz da subordinação à segurança trazida pelos benefícios sociais - cada vez mais rarefeitos - que as modalidades tradicionais de trabalho oferecem. No entanto, aqui existe um impasse; se a autonomia seria um elemento essencial na formação do reconhecimento (ao menos nas teses de Honneth e outros, que postulam sobre a autonomia como uma condição da formação do eu), como poderíamos pensar neste elemento de maneira isolada? Mais ainda: como entender que a busca por garantias pode, intrinsecamente, simbolizar uma perda da autonomia - ou, como propõe Linhart - escolher a perda de autoestima em nome de uma proteção contra a precariedade material?

Da mesma forma que o reconhecimento é um elemento central para uma relação saudável com o trabalho, a necessidade de autonomia e exercício intelectual no trabalho ${ }^{40}$ também ocupa uma posição central. Como conferir sentido à atividade se não se perceber reconhecido como capaz de realizá-la, ou ao menos que seu fazer tenha importância? Não sem razão, Dejours define a identidade no trabalho como a 'armadura da saúde mental', o que imediatamente nos lança à memória uma passagem do filme de Costa Gavras, 'O Corte' (Le Couperet, 2005). Há uma cena central na qual o demitido diz que ao tirarem seu trabalho, o que lhe tiraram

\footnotetext{
${ }^{40}$ Essa ideia é compartilhada por alguns autores mais recentes de diferentes formas; Malcolm Gladwell, por exemplo, afirma que as qualidades que o trabalho dever ter para trazer satisfação são autonomia, complexidade e uma conexão entre esforço e recompensa. (2008, P. 149), e que a reunião dessas três características são o que faria o trabalho ter sentido, propósito (no original, meaningful, P. 150). Daniel Pink também dá o devido peso à necessidade de autonomia, segundo ele, sobre quatro T's: autonomia sobre a tarefa, o tempo, a técnica e o time. (2009, P, 94). Esses seriam elementos fundamentais para manter um alto nível de motivação.
} 
foi a vida. Dejours define essa operação pela transferência - em dois tempos subjetivos - dos benefícios do reconhecimento pelo trabalho ao reconhecimento da pessoa, no registro do ser. Esse reconhecimento seria um elemento central do sentido subjetivo do trabalho, e nessa perspectiva percebemos como o trabalho se transforma de uma simples troca material em uma busca por um sentido, uma realização pessoal.

O autor Yves Clot tem uma passagem que ilustra a conexão entre os dois elementos: "Apoiado pelo reconhecimento, que nos conduz rapidamente a um reconhecimento por um outro, é que jaz a possibilidade de se recuperar aquilo que se fez. É necessária a verificação repetida de muitas vozes nas quais alguém pode se reconhecer em algo qualquer, que transcenda as circunstâncias intersubjetivas nas quais possa deixar sua marca. Quando não podemos responder deste "algo", não percebemos "autoridade em nosso trabalho", uma pessoa se perde. Somos mais reconhecíveis na medida em que somos capazes de ser autores de algo reconhecido para fora de nós, além de nós. O 'bem fazer' indexado a uma tradição profissional viva e, desta forma, o norte do 'bem estar'”. (Clot, 2015 P. 176 - 177. Trad. livre)

Discutir autonomia no trabalho seria uma tese em si; autores de campos diferentes se aproximam da questão da autonomia e utilizam perspectivas diversas para o fenômeno, especialmente ao discutir motivação. O trabalho de Daniel Pink intitulado Drive (2008) é um deles, e determina autonomia como um dos três pilares da motivação na contemporaneidade - acompanhada por Maestria e Propósito. O elemento comum entre autores é justamente que para haver motivação no trabalho, a possibilidade de escolher está no centro da equação. Assim como reconhecimento, autonomia é fundamental para conferir ao trabalho um sentido e conectar de forma coerente a dedicação e esforço a um sentido de propósito e realização. Contudo, uma forma de pensar no mal estar associado ao desejo de autonomia é partir de um elemento inerente ao próprio trabalho e que coloca diretamente em cheque a autonomia: a dominação. Seria a falta de autonomia um sintoma decorrente da dominação? 
O debate sobre trabalho e dominação deve ser tão antigo quanto o próprio trabalho. Ele ecoa o debate filosófico das idades clássicas entre a contemplação e ação, entre as atividades propriamente humanas como as artes, ciências e a vida pública (otium) e atividades destinadas a satisfazer as necessidades do corpo e, posteriormente, o comércio (Nec-otium) e retoma o argumento desenvolvido por Arendt na "Condição Humana” sobre necessidade e liberdade. De modo reducionista, não é possível pensar em uma relação de trabalho isenta de dominação caso o fruto de trabalho esteja associado a uma necessidade. Seja a dominação pelo outro - a subordinação - ou a dominação pelas próprias necessidades do corpo e do espírito, é um elemento que põe em xeque a própria possibilidade de autonomia na relação Homem-Trabalho.

Adorno e Horkheimer, em seu texto célebre a 'Dialética do Esclarecimento' desenvolvem uma tese complexa justamente para pensar neste conceito da dominação, assim como Hegel o fez ao pensar na dialética do Senhor e Escravo. Para esses autores, a dominação no trabalho é inescapável (assim como toda dominação a partir do lluminismo é inescapável). Assim como Arendt pensa a relação Homem e Natureza, os autores reforçam que desde que o homem se propõe a dominar a natureza e usá-la para seu consumo e conforto está eternamente preso a essa mesma dominação nas relações que irão se estabelecer entre os próprios homens; trata-se de Dialética do lluminismo (ou Esclarecimento) - ao dominar o mundo via conhecimento e tecnologia, o ser humano se coloca inadvertidamente como ator e alvo dessa mesma dominação. Trata-se de um passo além de pensar apenas nas relações entre classes; a dominação não se dá apenas na esfera das relações, mas na esfera da existência: ao estabelecer o ciclo de dominação, é impossível escapar dela sem colocar em xeque o próprio conceito da Cultura e, com ela, o Trabalho.

Entre outros temas abordados, podemos trazer essa passagem específica, interessante para ver uma reflexão semelhante à de Hannah Arendt no sentido do quanto a 'redução' do trabalho à simples produção e consumo traz em si uma realidade na qual o homem se torna supérfluo a partir de sua própria invenção. 
O que os homens querem apreender da natureza é como empregála para dominar completamente a ela e aos homens. Nada mais importa. (...) O que importa não é mais aquela satisfação que, para os homens, se chama "verdade", mas a "operation", o procedimento eficaz". (p20)

"Agora que uma parte mínima do tempo de trabalho à disposição dos donos da sociedade é suficiente para assegurar a subsistência daqueles que ainda se fazem necessários para o manejo das máquinas, o resto supérfluo, a massa imensa da população, é adestrada como uma guarda suplementar do sistema, a serviço dos seus planos grandiosos para o presente e futuro. Eles são sustentados como um exército dos desempregados. Rebaixados ao nível de simples objetos do sistema administrativo, que preforma todos os setores da vida moderna, inclusive a linguagem e a percepção, sua degradação reflete para eles a necessidade objetiva contra a qual se creem impotentes. (...) Perante um líder sindical, para não falar do diretor da fábrica, o proletário que por acaso se faça notar não passará de um número a mais, enquanto o líder deve por sua vez tremer diante da possibilidade de sua própria liquidação". (Adorno e Horkheimer, 1985. P. 49. grifo nosso)

O ciclo de produção e consumo impõe a dominação (do trabalhador, ao perceber sua condição de tão consumível quanto a matéria prima ou mesmo o consumo em si), e não há dialética que dê conta dessa dualidade. Talvez exceto pela utopia marxista na qual o homem se emanciparia do trabalho, o ciclo de dominação e esclarecimento tomado por uma relação dialética inescapável é um excelente meio de compreender as transformações pós Revolução Industrial (mesmo que esses autores pesquisem desde a Idade Clássica; um grande exemplo o personagem Ulisses de Homero como o 'proto-burguês' e seu paralelo com o burguês em si da era industrial e adiante $\left.{ }^{41}\right)$. Como o disse Olgária Mattos, em seu trabalho "Benjaminianas" (2009):

A (...) "dialética da razão" faz do "burguês" Ulisses - o herói prometeico, moderno, do interesse técnico astucioso e comandante do navio - um escravo, a igual titulo de seus marinheiros; esses, com ouvidos tapados, remam olhando adiante, como todos os trabalhadores, escravizados desde sempre; olhos vendados e ouvidos que não escutam (...). Quando ele, o "senhor" que ouve o

\footnotetext{
${ }^{41}$ Na "Dialética" há diversas passagens em que Adorno e Horkheimer estabelecem tal paralelo, e inclusive todo um capítulo, mas podemos citar como exemplo: "A unificação da função intelectual, graças à qual se efetua a dominação dos sentidos, a resignação do pensamento em vista da produção da unanimidade, significa o empobrecimento do pensamento bem como da experiência: a separação dos dois domínios prejudica a ambos. A limitação do pensamento à organização e à administração, praticada pelos governantes desde o astucioso Ulisses até os ingênuos diretores-gerais, inclui também a limitação que acomete os grandes tão logo não se trate mais apenas da manipulação dos pequenos". (Adorno, Horkheimer. 1985, P. 47)
} 
canto amarrado ao mastro do navio, torna manifesto que não há nenhum vencedor, todos são escravos: os companheiros de Ulisses, do trabalho que lhes é imposto; Ulisses, do próprio domínio.

(Mattos, 2009 p.133)

A discussão de autonomia pode ser pensada como derivada do elemento do reconhecimento: autonomia como um respeito à escolha e juízo do indivíduo que o reconhece como um sujeito - em oposição à autonomia como respeito ao tempo do trabalhador, da esfera da liberdade. No entanto, ao problematizar este primeiro viés da autonomia, podemos encontrar um entrave descrito por Linhart: o da ilusão de autonomia promovido por sistemas modernos de gerenciamento. Em um capítulo intitulado "Valores profissionais do privado e do público: um fogo cruzado perigoso" de seu livro de 2009 "Trabalhar sem os outros" (Travailer sans les autres?), a autora o detalha:

No mundo privado, os gestores passam então a associar a noção do engajamento e da implicação àquela do empregado corajoso, que sabe renunciar a suas vontades (...). Trata-se do empregado valente, que aceita mudar seus hábitos em função das necessidades da empresa, desta forma não negando a sua mobilidade, disponibilidade, horários atípicos, que condiciona sua vida privada e familiar às exigências da empresa".

É provavelmente aí que reside a "autonomia" realçada por alguns sociólogos que enxergam sobretudo a ruptura com o taylorismo. Existe uma certa autonomia do empregado, mas ela reside na necessidade de dar conta de todas obrigações a eles designadas muitas vezes contraditórias. As organizações de trabalho são pouco capazes de amenizar as tensões entre objetivos de qualidade e produtividade, e essa dificuldade é delegada em grande parte aos próprios funcionários, até o final da cadeia. (...). O modelo do "novo espírito do capitalismo" consiste, no fundo, de relegar ao empregado mais subalterno os riscos que eram outrora responsabilidade do empreendedor ${ }^{42}$.

(Linhart, 2009. P. 129 - 131, Trad. livre)

\footnotetext{
${ }^{42}$ A autora é cuidadosa com seus termos, mas atribui a uma série de forças e influências como mercado, cultura a expectativa dos empregados e a figura deste gestor hiper-racional e perverso. Marie-France Hirigoyen ecoa esta perspectiva em seu "Assédio Moral" (1998), posicionando-se claramente 'do lado da vítima' assim como Carl Ceredstrom e Peter Fleming em "Homem morto trabalhando" (Dead Man Working, 2012), na imagem do 'capitalismo morto', do trabalho inútil e sem sentido, das dinâmicas de grupo que só levam à humilhação. Os autores realçam o caráter intencional e utilitário do uso de ideais contra-culturais como rebeldia e autenticidade como a forma suprema de apropriação da subjetividade dos trabalhadores, enfim, o quanto o movimento capitalista se apropria de referências críticas e as converte em bases para novas formas de exploração do tempo e da capacidade de escolha.
} 
Podemos olhar a questão da dominação por outra perspectiva menos ontológica e mais ôntica; uma perspectiva do sujeito da pós modernidade, visto pela lente teórica da psicanálise francesa. Na discussão organizada por Dejours, parte-se da opinião de que se não houver qualquer dimensão de subordinação, não se trata de trabalho. A psicanalista Lise Gaignard, em seu texto "As figuras psicopatológicas da culpabilidade objetiva", explora essa conexão.

\begin{abstract}
É necessário (aos que organizam o trabalho de outros) exercer alguma forma de violência para obter a disposição da força de trabalho das pessoas que dirigem. Que sua tarefa seja produzir bens, venda de serviços ou organizar e manter a coesão social, o trabalho pode ser realizado de bom ou mau grado. O contrato que liga os trabalhadores à sua direção é um contrato de subordinação, uma certa obediência é prometida, embora todos saibam que é difícil obter do outro ou outros um assujeitamento tal que se prenda ao caráter flexível do trabalho, sua dureza, que cooperem entre si, que resolvam os conflitos que não faltam de se apresentar, que contornem ou superem as armadilhas que encontrem. Obter sua obediência não é o bastante, é necessário obter seu zelo, o engajamento de cada um. (...) A adesão corpo e alma é necessária. Digo corpo e alma, pois se a alma não estiver lá o corpo fala (...); se o corpo falhar (se o trabalho for muito penoso ou tóxico), a dor e a limitação invadem o tabuleiro.
\end{abstract}

(Gaignard, In Dejours, 2007. P. 153)

A subordinação é necessária, ao menos na grande maioria dos postos de trabalho na pós modernidade. Possivelmente com exceção do trabalho voluntário e do religioso - talvez possamos incluir em alguma medida o trabalho artístico toda atividade profissional demanda uma cadeia hierárquica (mesmo que informal ou na relação cliente/prestador). Contudo, como avançar do paradigma da dominação para a noção de autonomia? Mais ainda, será que não haveria um sintoma mais presente da falta de autonomia em jogo frente à dominação? Nossa hipótese aponta para um conceito central: o da alienação.

O conceito de alienação irá funcionar como um pano de fundo em toda a discussão sobre o desejo de autonomia, uma vez que pode representar uma solução de compromisso entre o sujeito e o mal estar no trabalho. Isento de qualquer julgamento moral neste ponto, o olhar atento mostra que face às pressões e conflitos que o mundo de trabalho pode promover, assim como nas 
neuroses, o mecanismo da clivagem pode representar uma saída para lidar com o conflito moral. Christophe Dejours (2015) descreve esse mecanismo quando fala dos recursos adotados por alguns indivíduos para lidar com o que nomeia o sofrimento ético, o conflito entre perceber uma incompatibilidade entre os próprios valores e premissas morais e as atividades que a hierarquia demanda.

Os novos métodos de gestão e gerenciamento, a avaliação individualizada de performance, a qualidade total, a precarização do emprego tem provocado um crescimento massivo do sofrimento ético. É esse sofrimento que implica, para o funcionamento psíquico, o fato de oferecer, nolens volens ${ }^{43}$, seu consentimento em participar de atos que moralmente reprovamos".

(Dejours et Al., 2015. P. 23, grifo nosso)

O mesmo conceito poderia ser imaginado em situações de mal estar extremo, nos quais mesmo sem haver uma contradição entre a atividade e os valores morais, exista uma impossibilidade de conciliar a vontade e a necessidade (por exemplo, e situações nas quais o sujeito se acredita obrigado a permanecer em um emprego que deteste por necessidade material ou impossibilidade real ou imaginada de recolocação profissional). Como Dejours descreve especificamente o sofrimento ético em situações nas quais o sujeito é conduzido a cometer atos que considera nocivos ao outro, ele nomeia esse trecho da "preguiça de pensar dos indivíduos".

Em virtude da análise proposta no trabalho vivo, o ser humano é duplo. Em nome do trabalho, da produtividade e da rentabilidade, ele pode ser conduzido a aportar seu consenso a atos que moralmente reprova. E ele não entra sempre em crise, apesar das contradições flagrantes que resultam de sua implicação nos atos, nas atividades ou ações profissionais que parecem bem incompatíveis com seus engajamentos intelectuais e morais na esfera privada. Como um sujeito conseguiria manter essa clivagem e ainda assim não se deixar submergir pela angústia? A fórmula mais utilizada é aquela da acrasia, essa falibilidade da vontade que conduz a atuar no sentido contrário do que indica o julgamento ou a razão.

Além disso, a acrasia tem isso de particular que ela me permite agir no inverso do que acredito ser justo ou bom, não somente em uma ocasião, um ato ou uma decisão pontual, sob um golpe de uma paixão que me possua, mas ao longo de toda minha vida profissional, cada dia, constantemente. Ela não é motivada pela paixão, mas pela comodidade, uma vez ser mais fácil e mais vantajoso do que entrar em resistência. Graças a essa clivagem, eu sei o que é justo ou bom,

\footnotetext{
${ }^{43}$ Latim para "Querendo, ou não", ou como diríamos coloquialmente, 'por bem ou por mal'.
} 
eu até defendo a altos brados, e respeito esses juízos na maior parte dos atos da minha vida cotidiana. No entanto, ao mesmo tempo, eu faço em minha vida profissional o inverso do que me indica meu senso moral.

A fraqueza da vontade, quando ocorre, começa antes do ato: ela se apoia no próprio pensamento. O que abandono ao estado do impensado, é precisamente a contradição entre o que digo e faço de maneira coerente de um lado, e o que faço no sentido inverso ao que digo, de outro. Se eu fizesse face a esta contradição seria vencido e certamente arruinado pela angústia. E se eu não me desfizesse neste conflito, terminaria derrubado pela doente, de um ponto de vista psíquico ou somático. A fraqueza da vontade, aqui, é mantida e precedida por uma forma particular de preguiça intelectual: meu pensamento entorpece assim que ele se aproxima do conflito entre o pensar e o agir, ele foge. E assim, eu penso em outra coisa que me distraia de modo a me afastar do conflito.

Diferente desta acrasia preguiçosa, podemos também identificar a acrasia estênica. Esta última se caracteriza pela exigência de dar uma razão para a incoerência. Para que ela não coloque em causa a clivagem, essa argumentação não deve proceder de uma deliberação pessoal. Ela é emprestada do exterior com base em frases feitas, fórmulas do café du commerce, slogans ou estereótipos. "É assim, não tem outro jeito de fazer"; "são as ordens, não temos escolha"; "É o sistema, não podemos fazer nada"; "é preciso ser realista"; "é a guerra econômica".

(Dejours et Al., 2015. P. 89-90. Trad. livre)

Trata-se efetivamente de um elemento essencial para refletir sobre o mal-estar e a contemporaneidade. A hipótese de Dejours é que as transformações do capitalismo causaram distorções na forma das relações entre empregadores e subordinados.

Que nas relações comerciais ordinárias ou nos centros de atendimento (...) os clientes são enganados pelas publicidades mentirosas ou por alguns agentes técnico-comerciais dúbios, venais, gananciosos ou corrompidos, não há nada de novo. Mas que os trabalhadores que não são corrompidos aceitem colaborar com a banalização e a normalização da corrupção, travestida em busca legítima pelo desempenho, é um fenômeno inédito, que se paga pelos atos suicidas à repetição. De consentir em dar seu apoio (concours) a práticas que o senso moral reprova, como lograr os clientes sistematicamente e sob ordens da hierarquia para "fazer os números", envolve um número de agentes não só na experiência da traição do cliente, mas também na traição de si.

(Dejours et Al., 2015. P. 83. Trad. livre) 
Esta ideia das acrasias é essencial para fundamentar a hipótese do sofrimento pela falta de autonomia para escolher, e potencialmente um dos conceitos mais elegantes de Dejours. O autor publicou em 2012 um livro de entrevistas suas por Béatrice Bouniol, chamado "La Panne: repenser le travail et changer la vie" (A Pane: repensar o trabalho e mudar a vida, 2012) e neste livro, há um detalhamento mais didático - e mais engajado em termos de seu posicionamento político - no qual demostra com mais clareza o caminho para formação das 'acrasias' e, em especial, sua relação próxima com o tema da autonomia.

\begin{abstract}
A avaliação individual de desempenho minou toda a cooperação, que, em si, era engajada na produção ou elaboração de uma proteção contra o sofrimento. Aqui está a mudança mais importante desde o taylorismo: as estratégias de defesa coletivas tornam-se impossíveis. As construções que outrora permitiam afrontar coletivamente o medo traziam a possibilidade de uma resistência, de uma luta comum contra um sistema opressivo, e eram compatíveis com o surgimento de um movimento operário e sindicalista. Sob o efeito das novas metodologias de gestão, esta via é bloqueada. Só permanecem possíveis as estratégias de defesa individuais, com os perigos particulares que estas trazem consigo. Nas construções coletivas, a negação, assumida por todos, se transforma em crença compartilhada. A negação individual é sempre parecida com um delírio, e traz ao sujeito o risco da patologia. Ela pode tomar duas formas, a autoaceleração ${ }^{44}$ e a clivagem.
\end{abstract}

Cada um de nós experimenta a clivagem a minima, com maior ou menor importância. Viver na negação daquilo que nos angustia, mesmo que temporariamente, é nosso fardo. Não somos capazes de ignorar nem a miséria nem a guerra, mas tentamos esquecê-lo durante nosso cotidiano. Face a dureza do mundo do trabalho e da derrota das estratégias coletivas, a clivagem é recebida como um último recurso do sujeito, que se comporta então como se duas partes o constituíssem e agissem como se uma desconhecesse a outra. Esse arranjo consigo passa pela acrasia: sob sua forma preguiçosa, ela leva o sujeito a se recusar a pensar sobre uma situação que parece complexa demais para si. Ela se apoia muitas vezes em um relativismo generalizado, tanto na verdade como na ética. Já sob sua forma chamada "estênica", ela acompanha de um imperativo ensurdecedor: "não temos escolha", "é a guerra econômica" ... Esse racionalismo se limita então à adesão mais ou menos fundamentada a discursos dominantes, como se fossem propostas de um café du commerce... Muito além de suas distinções de estilo, ambas as formações assinalam uma renúncia à autonomia.

\footnotetext{
${ }^{44}$ Segundo o autor, uma estratégia de defesa na qual o sujeito se transforma em um autômato pela sobrecarga de trabalho, cujo efeito principal é o imediatismo das decisões e a 'impossibilidade' (ou escolha) de parar para pensar. Vale lembrar que em 2003 Nicole Aubert já havia publicado sua tese sobre este mesmo fenômeno, sobre a qual mencionaremos em seguida.
} 
A acrasia se instala a partir do momento em que o sujeito é levado a cometer um ato que entra em contradição com o que pensa. O passo decisivo o põe face a face com aquilo que há de mal em si, e, potencialmente, em toda humanidade. O equilíbrio psíquico deste indivíduo é lançado à conclusão que essa prova representa. Se considera a si marcado pela existência generalizada do mal, encontrará justificativas para seus atos, e irá até transformar-se em um defensor do sistema - se for um processo de acrasia estênica que se desenvolver - ou então se contentará em ter se safado daquilo, se porventura desenvolver uma acrasia preguiçosa. Mas o que foi aquilo que o fez concluir que o mal estava dentro de si? Me parece aí um ponto crucial para conhecer o consentimento com o mal. O conhecimento que os indivíduos têm dos riscos que provocam nos outros ao colaborar com o sistema forja neles uma consciência pesada. Cada tomada de consciência redobra esse sofrimento que mobiliza todas suas defesas a apaziguar e reduzir a capacidade de pensar. Aí está a armadilha: as defesas que o permitiriam resistir, atenuar o sofrimento que emerge das condutas que o revoltam, diminuem sua capacidade de sentir-se como alguém que provoca o sofrimento em outros, e, ao mesmo tempo, os subjuga ao sistema.

(Dejours, C. Bouniol, B. 2012. P. 30 - 32. Trad. livre)

Bernard Doray também debateu a validade conceitual de transitar de conceitos eminentemente psicanalíticos - e, portanto, que dizem respeito à esfera individual - ao aplicá-los na relação homem-trabalho. Bastante rigoroso, especialmente no tocante ao uso de construções marxistas de maneira superficial, ainda assim Doray traz uma reflexão única sobre o fenômeno já mencionado da alienação.

Talvez compreenderíamos melhor alguns efeitos do sofrimento na relação de trabalho se buscarmos conhecer melhor os processos de ruptura, de englobamento e de captação, em resumo, de alienação em parte consentida que estabeleceram esse potente sistema de identificação social com a psique desses sujeitos, desde que esses últimos se identificaram com essa hegemonia [o sistema de mercantilização de homens e mulheres].

(...) Evidentemente, essa interiorização, essa passagem de matrizes exteriores de identificação ao domínio psíquico não pode ser considerada como um processo simples e não contraditório, nem como um processo puramente intelectual: toda uma leitura da relação subjetiva ao trabalho poderia se fazer em termos de introjeção e rejeição, da tomada de distância e da desvalorização destas matrizes de identificação.

Resta que a análise da relação subjetiva com o trabalho, como aquela dos efeitos psíquicos referentes às situações de ruptura com o meio de trabalho, mostra com força que essa interiorização das matrizes exteriores é um processo vivo e permanente".

(Doray, 2011. P. 122. Trad. livre) 
A análise subjetiva nos permite explorar com alguma precisão os efeitos nocivos da falta de autonomia; a saúde mental e a própria capacidade de produzir, que seria vitalizante, trazem sua face negativa nos trabalhadores. Podemos, assim, pensar em ao menos duas faces da autonomia; do lado positivo, perceber-se responsável pelas escolhas profissionais conduz a um sentimento de protagonismo e mesmo autoria pelo próprio fazer. Para estabelecer a diferença entre um comportamento automatizado (ou "Labor", na classificação de Hannah Arendt) e uma produção intencional (mais no campo do "Trabalho") deve ter existido o processo de reflexão, aquisição de conhecimento ou ao menos alguma razão consciente pela qual aquela tarefa seria necessária ou mesmo útil. Também haveria o outro lado, mais ligado à falta de autonomia e que gera a alienação ou leva ao que Dejours afirma ser o sofrimento ético. Uma tarefa desempenhada sem qualquer liberdade de escolha ou mesmo contrária aos próprios valores e crenças morais pode transformar mesmo o mais complexo dos trabalhos em algo análogo à escravidão. Em muitos casos essa pode ser uma escolha consciente de vida, mas muitos outros envolvem, inclusive a obrigação de se acomodar a escolhas que ferem os próprios valores morais ou éticos. ${ }^{45}$

Outra estratégia coletiva de defesa detalhada por Dejours em situações nas quais não há essa possibilidade de deliberação e diálogo é o que nomeia a 'Greve do Zelo' (Dejours, 2015. P 108-109). Sem os espaços para dialogar e realizar a atividade deôntica, ou a possibilidade de negociar regras para o trabalho, os assalariados se proporiam a fazer exatamente o que seus líderes demandam, sem exercer juízo crítico ou aplicar sua própria inteligência no processo. Frequentemente, os resultados são nefastos, como acidentes de trabalho, quebras, adoecimento. Enfim, pode-se ter uma dimensão apurada dos efeitos

\footnotetext{
${ }^{45}$ Há inúmeros casos publicados na literatura que trazem à tona situações como esta, assim como existem exemplos clínicos. Um desses relatos recentemente publicado foi feito pela psicanalista Marie Grenier-Pezé em um capítulo intitulado "Le harcèlement moral au travail: contrainte par corps" (algo como 'O assédio moral no trabalho: constrangimento dos corpos [em ambos sentidos]). Neste texto, ela descreve o tratamento de uma paciente chamada Solange, 52, uma operadora de telemarketing. Algum tempo depois, a Diretora desta mesma companhia - Mme. T. - procura esta mesma psicanalista. Solange teve diversas crises nervosas e acabou próxima de ter um AVC no ambiente de trabalho. Sua superiora hierárquica, Mme. T. Começou a ter crises de angústia debilitantes após ver Solange desfalecer no chão e ser removida por paramédicos do escritório. (In: Dejours et al. 2010. P. 109 - 129)
} 
nocivos que essa falta de autonomia pode provocar na força de trabalho e nos indivíduos.

No limite da ausência da percepção de ter autonomia ou controle de suas ações, também tocamos o terreno do controle sobre o próprio tempo. Nicole Aubert trabalhou esse tema em seu 'O Culto da Urgência' ("Le Culte de l'Urgence: la Societé Malade du Temps", 2003). Ela afirma que no momento em que a tecnologia e a lógica do capitalismo requerem que os trabalhadores entreguem resultados na mesma velocidade e dinâmica do mercado de Bolsa de Valores, o tempo para reflexão ou introspecção para a maioria dos assalariados é reduzido ao mínimo. A compressão de tempo exigida para prover o máximo de valor com o mínimo de recursos provoca uma transformação na interação entre pessoas, ainda mais amplificada com o advento da conectividade e os mercados interligados pela Globalização. Com pessoas permanentemente conectadas em diferentes fusos horários e uma expectativa de reação instantânea a toda e qualquer requisição, urgência, instantaneidade, imediatismo e rapidez se fundem em uma só forma de funcionamento. Cria-se um contexto no qual o controle sobre o tempo e a negociação de resultados e metas torna-se quase impossível. Se as expectativas veladas dos acionistas são de uma apropriação total do tempo e habilidade de produzir dos assalariados, desde que haja a necessidade de trabalhar - e um banco razoável de desempregados que tenham disposição para repor qualquer posição vaga - a autonomia para negociar ou recusar demandas se reduz a um mínimo. Isso se confirma na experiência da clínica; quanto mais alta a posição na hierarquia, o aumento do estresse é exponencial. 
A vida social é definida em seu conceito fundamental como uma relação de luta por autoconservação; (...) Da política clássica de Aristóteles até o direito natural cristão da Idade Média, o homem fora concebido em seu conceito fundamental como um ser capaz de estabelecer comunidades, um zoon politikon que dependia do quadro social de uma coletividade política para realizar sua natureza interna; somente na comunidade ética da polis ou da civitas, que se distingue do mero contexto funcional de atividades econômicas devido à existência de virtudes intersubjetivamente partilhadas, a determinação social da natureza humana alcança um verdadeiro desdobramento." (Honneth, 2003. P. 31)

“(...) [A] vida pública teria que ser considerada não o resultado de uma restrição recíproca dos espaços privados da liberdade, mas, inversamente, a possibilidade de uma realização da liberdade de todos os indivíduos em particular.

(Honneth, 2003. P. 41)

Qualquer reflexão sobre espaço público versus privado, ou sua encarnação moderna e hipermoderna de 'trabalho versus qualidade de vida' exige como ponto de partida pensar na relação Eu-Outro. Desde o pensamento de Hegel até a Escola de Frankfurt, do qual Axel Honneth é um dos herdeiros da tradição crítica, a relação Eu - Outro é um passo transformador para pensar tanto na dinâmica do reconhecimento como na relação entre o público e o privado. Desde Jacques Lacan no campo da Psicanálise (via Alexandre Kojéve) até Richard Sennet na Sociologia, parte-se dos elementos mais essenciais da formação do eu para, a partir daí estabelecer uma conexão crítica com o meio social. Mesmo Heidegger, que questiona e mesmo acusa o conceito da consciência como ponto de partida, reconhece que o eu só pode se constituir na relação com o mundo, com o inevitável estar-aí ou ser-no-mundo.

Desta forma, pensar na relação trabalho e tempo privado pode ser uma visão parcial de algo muito mais complexo. O pensamento psicanalítico trabalha esta tensão justamente ao ampliar princípios fundados na metapsicologia freudiana, que inicialmente dava ênfase aos processos eminentemente intrapsíquicos. É sob a influência de autores da tradição inglesa, em especial Wilfred Bion e D. W. 
Wininicott, que a dinâmica do funcionamento intrapsíquico começa a se articular com a relação mãe - bebê, e abre-se a oportunidade para imaginar conceitos que estabelecem esta relação de simultaneidade e interdependência entre o olhar Eu > Mundo Interno e a relação Psiquismo > Mundo Exterior. Não por coincidência, grande parte desses autores produziram, influenciaram e forma influenciados pelo pensamento lacaniano que posteriormente se articularia de forma análoga pela construção do modelo Imaginário, Simbólico e Real.

Vejamos um exemplo disso no conceito de co-corporeidade, elaborado por Nelson Coelho Jr. e descrito em seu texto de 2010. No trabalho "Da intercorporeidade à co-corporeidade: elementos para uma clínica psicanalítica" e em outros anteriores, o autor traz uma elaboração do conceito de cocorporeidade que explora justamente a natureza inseparável, simultânea e essencial das dinâmicas propriamente intrapsíquicas identificadas por Freud e as dinâmicas de ordem intersubjetiva. Trata-se de certa forma de expor a amarração necessária na clínica dessas dimensões simultâneas e de dinâmicas profundamente distintas, mas ambas fundamentais ao funcionamento humano.

A necessidade de reconhecer, simultaneamente, as dimensões intrapsíquicas e intersubjetivas, impõe a opção por noções que contemple essa simultaneidade. Considero que o difícil abandono desse dualismo, assim como o difícil abandono dos impasses que envolvem a oposição clássica entre o corpo e o psiquismo, é o que ainda impedem que a psicanálise possa encontrar um lugar definitivo para a experiência e o conceito de corporeidade (como o defini), tanto em termos metapsicológicos como em termos clínicos.

Sugiro, portanto, que passemos a pensar o fundamento do campo analítico como uma co-corporeidade, um tecido material e energético, móvel e instável, movido por forças pulsionais mensageiras e marcado por interferências de influências internas e externas, constituindo um campo de forças e protosentidos. Não há como expulsar a dimensão pulsional da corporeidade, tampouco o Eu e o inconsciente. Mas também não há como negar a dimensão relacional.

(Coelho Jr, 2010. P 59)

Ao trazer em conjunto elementos da fenomenologia de Husserl e Merleau-Ponty - além de uma revisão detalhada de autores como o casal Baranger, Thomas Ogden e Andre Green - Coelho conceitua o campo analítico como esse 
entrelaçamento de forças. Para além disso, podemos pensar que a própria ideia da formação do Eu, em especial do Eu com o outro, o Eu com a dimensão social - ou com a linguagem - é influenciada por essa mesma dinâmica. Há uma base psicanalítica na Sociologia Clínica e mesmo nas Sociologias críticas modernas, nos faria compreender melhor estas crises e conflitos que emergem da relação do homem com sua identidade pública em oposição à identidade privada. ${ }^{46}$

Para Richard Sennet, por exemplo, um dos elementos de discussão nas ideias modernas a respeito da vida privada é justamente a noção de que a 'vida psíquica, tão preciosa e delicada fenecerá se for exposta às duras realidades do mundo'. Este autor marca justamente uma retomada pós moderna (ou diríamos, hipermoderna) do oposto deste "homem hegeliano" para o qual o espaço público seria o espaço privilegiado de realização do Eu para, ao contrário, valorizar a elevação do mundo privado como espaço de proteção. Trata-se de ideias que Hannah Arendt já havia trabalhado em seu "A Condição Humana", mas articuladas para realçar esse gradual colapso do 'homem público' nas sociedades da pós modernidade.

A introdução de Sennet ao tema em seu trabalho seminal "O Declínio do Homem Público" já dá o tom: na sociedade pós Guerras Mundiais, o Eu só pode florescer se protegido desta dureza do mundo. Conhecer a si tornou-se uma tarefa em si ao invés de um meio para conhecer o mundo ou o outro. "E precisamente por estarmos tão absortos e nós mesmos, é-nos extremamente difícil chegar a um princípio privado, dar qualquer explicação clara para nós mesmos ou para os outros do que são nossas personalidades. A razão está em que, quanto mais privatizada é a psique, menos estimulada ela será e tanto mais nos será difícil sentir ou exprimir sentimentos". (Sennet, 2014, P. 16-17)

\footnotetext{
${ }^{46}$ Esta nossa hipótese pode ser vista como reducionista se vista em um contexto mais amplo; há pesquisas, por exemplo, que já começam a associar 'interações negativas entre domínios de vida' - outro nome para conflitos ligados ao trabalho ocupando tempo da vida familiar ou privada - com distúrbios neuroesqueléticos, como o de Efreing, Igic, Semmer, et al., de 2016. Esse estudo cita até uma nova nosografia sendo estabelecida, a 'Hipótese de Cinderela', aludindo à personagem que 'começava a trabalhar assim que raiava o dia e terminava por último'. Trata-se de um tipo específico de sobrecarga muscular associada a estímulos frequentes e de longa duração em unidades musculares menores, de menor resistência, que só seriam recuperadas após o relaxamento total do músculo.
} 
Sennet critica o que chama das "tiranias da intimidade", a obsessão da sociedade moderna com a valorização da privacidade individual ou grupal que promove uma erosão na importância (e relevância) do espaço público como base para a sociedade. A hipervalorização das intimidades também pode ser vista como uma ameaça à construção de projetos comuns de convivência - à exceção feita aos "grupos de iguais" - e isso pode ter um profundo impacto nas organizações e instituições privadas. Conforme tendências individualistas progridem, as organizações se veem frente à difícil tarefa de construir propostas individualizadas a cada necessidade dos sujeitos ao invés de oferecer as melhores condições possíveis de trabalho a todos os trabalhadores e repensar a própria dinâmica do trabalho. Não por acaso ecoa ideias formuladas por Marx quando propunha que a utopia deveria ser a emancipação do Homem da necessidade de trabalhar, e não apenas a luta de classes por condições melhores, como comentado por Hannah Arendt em seu "A Condição Humana". (Arendt, 2008)

Além de discriminar Labor e Trabalho, é nesta obra que Arendt explora com a sociedade Romana lidava com a questão público versus privado. O campo do privado era essencialmente o das necessidades, como a vida sexual conjugal, as necessidades de higiene do corpo, o trabalho escravo e tarefas domésticas. "As palavras Gregas e Latinas para o interior de uma casa, megarom e atrium, têm uma conotação forte de escuridão e predominância do negro (blackness)". (Arendt, 2008. P. 71) O interior, e eminentemente privado era o espaço do que deveria ser escondido.

A segunda característica notável não privativa da privacidade era que as quatro paredes da propriedade privada de alguém ofereciam o único lugar confiável para se esconder do mundo público comum, não somente contra tudo que se passava por lá mas também da própria publicidade, de ser visto e ouvido. Uma vida passada inteiramente em público, na presença de outros, se tornaria, podemos dizer, superficial. Enquanto retém sua visibilidade, perde a qualidade de trazer à vista algo de uma origem mais obscura que deve permanecer escondida, se não a sua profundidade em um sentido muito real, não subjetivo. O único meio eficiente de garantir que a escuridão daquilo que deve ser escondido da luz da publicidade é a propriedade privada, um lugar possuído de forma privada no qual é possível se esconder. 
(Arendt, 2008. P. 78)

Efetivamente, Hannah Arendt foi a grande pensadora na questão público/privado. Mesmo antes das mazelas atuais em relação ao trabalho e o caráter insidioso de como as novas tecnologias de comunicação podem ser usadas para mesclar o espaço privado ao tempo de trabalho, a autora já apontava o risco ao fazê-lo.

Jonathan Crary, da Universidade da Columbia, é um dos autores que destacam a contribuição de Arendt para esta discussão. Em seu livro "24/7: Capitalismo Tardio e os Fins do Sono", ele introduz a sua pesquisa em relação à importância do sono para a subjetividade, e, especialmente, no risco que o trabalho "24/7" representa à qualidade do sono. Trata-se de uma teoria que ecoa ideias como as de Nicole Aubert (em seu "A Sociedade doente pelo tempo"), sem deixar de mencionar a centralidade das ideias de Arendt para este tema.

Uma corrente da teoria política contemporânea afirma que expor-se é uma característica constitutiva fundamental, ou trans-histórica, do indivíduo. Antes de ser autônomo ou autossuficiente, um indivíduo só pode ser entendido em relação ao que está fora dele, a uma alteridade que o enfrenta. Apenas neste estado de vulnerabilidade pode haver uma abertura para as relações de dependência que mantém a sociedade. No entanto, vivemos um momento histórico no qual essa condição nua de exposição foi desarticulada de sua relação com formas coletivas que, ainda que de maneira tímida, ofereciam salvaguarda ou proteção. O modo como Hannah Arendt explora esses problemas em sua obra é especialmente significativo. Por muitos anos, ela recorreu a imagens de luz e visibilidade em suas análises sobre o que era necessário para uma vida política digna do nome.

Para um indivíduo ter relevância política, deve haver um equilíbrio, um movimento pendular entre a exposição ofuscante, estridente, da atividade pública, e a esfera protegida, blindada, da vida doméstica ou privada, do que ela chama de "trevas da existência resguardada". Em outro momento ela se refere à "meia-luz que ilumina a nossa vida privada e íntima". Sem o espaço ou o tempo da privacidade, longe da "luz implacável e crua da constante presença de outros no mundo público", não se pode fazer uma contribuição substancial para os debates a respeito do bem comum.

Para Arendt, a esfera privada devia ser distinguida da busca individual de felicidade material na qual o eu é definido por suas aquisições e por aquilo que consome. Em A condição humana, ela desenvolveu esses dois conceitos em termos de um equilíbrio rítmico entre exausto e regeneração: de um lado, a exaustão que resulta do trabalho ou da atividade no mundo; do outro, a regeneração que ocorre regularmente no interior de um espaço doméstico acolhedor e sombreado.

(Crary, 2016. P. 30-31) 
Efetivamente, na "Condição Humana" Arendt utiliza com maestria a metáfora de luz e trevas - potencialmente inspirada pelos trabalhos de Walter Benjamin ao comentar o repúdio de Baudelaire quando Paris foi eletrificada. Ainda assim, o aspecto essencial vai além da distinção entre luz e trevas; trata-se, enfim, de marcar a importância de separar o visível daquilo o que deve ser resguardado.

\begin{abstract}
A distinção entre os reinos público e privado, do ponto de vista da privacidade ao invés do corpo político, se iguala à distinção entre coisas que deveriam ser mostradas e coisas que deveriam ser escondidas. Somente na era moderna, com sua rebelião contra a sociedade, se descobriu o quão rico e versátil o reino do escondido pode ser nas condições de intimidade. É impressionante como desde o início da história até a nossa época sempre foi a parte corporal da existência humana que precisava ser escondida na privacidade, todas as coisas conectadas com o próprio processo da necessidade da vida, que até a era moderna compreendia todas as atividades que servem a subsistência do indivíduo e a sobrevivência da espécie. Escondidos estavam os trabalhadores (laborers) que "com seus corpos atendem às necessidades [corporais] da vida e as mulheres que com seus corpos garantem a sobrevivência física da espécie. Mulheres e escravos pertenciam à mesma categoria e eram escondidos não só por ser propriedade de outra pessoa, mas porque sua vida era "laboriosa", dedicada às funções do corpo. No início da era moderna, quando o trabalho [labor] "livre" perdeu seu esconderijo na privacidade do lar, os trabalhadores foram escondidos e segregados da comunidade como criminosos atrás de paredes altas e sob constante supervisão. O fato que a era moderna emancipou as classes trabalhadoras e mulheres praticamente no mesmo momento histórico deve certamente ter contado entre as características de uma era que não mais acredita que as funções corporais e preocupações materiais deveriam ser escondidas. É ainda mais sintomático da natureza desses fenômenos - mesmo na nossa civilização - que os poucos remanescentes da privacidade rígida sejam relativos a "necessidades" no sentido original de ter necessidades por ter um corpo.
\end{abstract}

(Arendt, 2008. P. 72 - 73)

Trata-se de uma articulação essencial entre a privacidade, o corpo e o labor; efetivamente, para Arendt, o trabalho efetuado na esfera privada está essencialmente ligado ao corpo, e estas relações que foram gradualmente transpostas - ou igualmente influenciadas - pelas mudanças socioculturais da época. Ainda assim, Arendt ressalta a importância de cada um desses elementos 
em sua própria característica, e como a coordenação destes compõe efeitos essenciais na subjetividade de cada época.

Embora a distinção entre privado e público coincida com a oposição de necessidade e liberdade, ou futilidade e permanência, e, finalmente, de vergonha e honra, não é de forma alguma verdadeiro que só o necessário, o fútil e o vergonhoso tenham seu próprio lugar no reino privado. O significado mais elementar dos dois reinos indica que há coisas que precisam ser escondidas e outras que precisam ser mostradas publicamente se é que elas devem mesmo existir. Se olharmos para isso independente de como são encontradas em qualquer civilização, veremos que cada atividade humana aponta para seu lugar apropriado no mundo.

(Arendt, 2008. P. 73)

Como demonstra Arendt, no pensamento clássico o espaço público (ou a Res Publica, a coisa Pública) era o teatro social no qual admiração, mérito e realização poderiam acontecer. O espaço público era considerado moralmente superior, o espaço da honra e da reputação. Com as transformações históricas - em especial o surgimento da burguesia na Europa -e o nascimento do capitalismo e acumulação de riquezas por não aristocratas, o espaço privado gradualmente se transformou no campo do "Eu Verdadeiro" e sua manifestação, e o espaço público é dominado por artifícios da 'atuação social' como a moda, a etiqueta e as negociações em geral.

Com o desenvolvimento da tecnologia de telecomunicação, mudanças como a necessidade de visibilidade no domínio digital - ou virtual - a possibilidade de interferência de empregadores de forma direta no espaço tido como privado e mesmo o trabalho contínuo desafiam a fronteira entre o tempo pessoal e tempo de trabalho. Esse fenômeno não é unívoco; também podemos encontrar exemplos nos quais indivíduos voluntariamente optam ou mesmo baseiam sua realização pessoal em uma integração extrema entre público e privado. No polo oposto dos indivíduos que sofrem com essa suposta 'invasão' do pessoal, há sujeitos para os quais o funcionamento psíquico é mais confortável no domínio do trabalho, em contraste a um funcionamento empobrecido no contexto privado. Fenômenos como o vicio do trabalho (workaholism), o karooshi asiático 
(ou 'morrer de tanto trabalhar), síndromes como o Burnout e outros fatores que afetam também a ligação com o tempo e autonomia podem ser influenciados por essa relação entre público e privado.

A reflexão de Arendt mostra seu impacto como a grande pensadora da tensão entre público e privado na contemporaneidade. No entanto, na esfera clínica, é importante considerar que cada subjetividade reage a esta tensão de modo único; existem indivíduos para os quais o espaço público permanece como o grande cenário da realização ou expressão saudável do eu. Desta forma, é essencial considerar não apenas os efeitos da 'invasão' do público no privado, mas também seu inverso: há sujeitos para os quais o espaço público permanece como o espaço da segurança e validação de si.

Christophe Dejours, em seu 'Observações Clínicas em Psicopatologia do Trabalho' (Observations Cliniques en Psychopathologie du Travail, 2010), apresenta um exemplo interessante de uma inversão entre a tensão clássica entre público e privado. Trata-se de mais um viés desta dimensão problemática do público / privado: existem sujeitos que, efetivamente, irão experimentar maior confiança ou afirmação de si no domínio público, mais especificamente no campo do trabalho. Ele descreve o caso de um trabalhador da construção civil, um imigrante do Magreb que se estabeleceu em Paris e trabalhou duramente para apoiar sua família, ainda residente na África. Quando a família se desloca para Paris, finalmente, esse trabalhador começa a experimentar crises de asma, e um terror inédito ao perceber os riscos aos quais se via submetido a meses. Segundo esse autor, existe esse novo componente do mundo privado que passa a resignificar o trabalho como algo arriscado, e transforma as 'economias intersubjetivas' evolvidas nessas atividades realizadas no mundo público.

Esse tipo de economia das relações intersubsubjetivas na vida afetiva e familiar, e mais amplamente no espaço privado, não se dá apenas pelo fato de um simples "conformismo cultural" (...), mas uma articulação bem sucedida entre a lógica da estratégia coletiva de defesa e a virilidade defensiva contra o medo no canteiro [de obras], de um lado, organização das relações no espaço privado, de outro, de forma que a continuidade seja assim estabelecida e mantida. Viril no canteiro, o homem exibe assim sua virilidade nos comportamentos privados, embora os parceiros do espaço privado 
o tolerem ou querem cooperar (o que não é sempre o caso; às vezes a crise familiar é inevitável).

(Dejours, C. 2010. P. 36. Trad. livre)

Esse papel da vida familiar - e da tensão entre público e privado - aparece também em outro trecho da obra de Dejours. Dejours e Guernet (2012) destacam as tensões na esfera privada como um dos desdobramentos dos 'sofrimentos éticos'; "As incidências das relações de trabalho sobre a economia das relações íntimas e as relações do corpo são muito mais importantes do que se considera no senso comum. Muitas dificuldades e conflitos na vida familiar são de fato sobredeterminadas pelas incidências dos desafios do trabalho no funcionamento psíquico como um todo. Por não serem capazes de desestabilizar um compromisso psíquico com as limitações do trabalho, conduzido com dificuldade, muitos sujeitos entram em conflito com as pessoas mais próximas, cônjuges e filhos". (Dejours, C. Gernet. I., 2012. P. 125, trad. livre) Nesta mesma linha, os autores exploram os efeitos insidiosos de conflitos internos tanto na priorização do profissional em detrimento do pessoal, questões de gênero e outros elementos de tensão entre modalidades éticas de funcionamento que se chocam entre o mundo das relações de trabalho e outras esferas - ou 'cenas sociais'.

Trata-se, evidentemente, de uma perspectiva diferente do que a maioria experimenta no mal estar no trabalho. Inclusive, destoa da experiência da maioria: a de um sofrimento ampliado pela solidão promovida pela forma cada vez mais individualista fomentada pelas novas formas de gestão. A autora Daniéle Linhart, em seu livro 'Trabalhar sem os Outros' (2017), detalha especificamente como ferramentas de gerenciamento como a avaliação individual do desempenho, o desmantelamento gradual do poder das organizações sindicais e outros movimentos contemporâneos contribuem para a erosão das coletividades e desembocam em um gradual aumento do 'sofrimento' contemporâneo no trabalho. 
obscena, ela já não se inscreve em experiências coletivas, afetando diretamente a pessoa para além do trabalhador. A gestão foca cada vez mais a dimensão íntima do indivíduo, em detrimento de sua dimensão profissional, isto é, bem mais suas habilidades interpessoais do que o conhecimento e o ofício, dimensões inerentemente mais coletivas.

(Linhart, 2017. P. 16. Trad. livre)

Linhart é mais uma das autoras que trata deste tema ressaltando um elemento essencial da contemporaneidade: para garantir o máximo retorno sobre o capital, não basta explorar o esforço corporal dos empregados. A subjetividade, criatividade e outros elementos que até então seriam mais presentes no campo do privado tornam-se commodities essenciais para 'fazer o impossível se tornar possível', como um entrevistado seu afirma. Para se obter o comprometimento total, esta dimensão do afetivo deve ser, também, apropriada pelo mundo do trabalho.

Para além dos autores franceses, possivelmente a autora que melhor explorou essa interface entre os afetos e o Capitalismo contemporâneo foi a socióloga israelense Eva Illouz. Além de uma questão simples de investimento de tempo e exposição, a reflexão de Eva Illouz (2007) sobre a separação público/privado detalha as mudanças sociais e históricas que geraram o que ela chama de Capitalismo Emocional, como a importância da separação entre vida privada e vida pública para a saúde psíquica. Pensando na tese dessa autora sobre o Capitalismo Emocional (2007), nos idos de 1900 o mundo do trabalho era totalmente separado do mundo da intimidade.

Quando vemos as emoções como os personagens principais na história do capitalismo e modernidade, a divisão convencional entre uma esfera pública a-emocional e a esfera privada saturada de emoções começa a se dissolver, conforme se torna mais aparente que ao longo do Século XX homens e mulheres de classe média foram forçados a dar um foco intenso em suas vidas emocionais, tanto no ambiente de trabalho como na família por meio de técnicas similares de trazer ao primeiro plano o self e suas relações com outros.

(lllouz, 2007 P.4) 
Assim como Arendt, Illouz marca a separação de um personagem mais social, público, e outro mais espontâneo e 'desprotegido', que se revela na intimidade. Essa dualidade, mesmo que abstrata e de certa forma teatral, oferecia um resguardo. A vida emocional estava confinada ao privado, assim como falar sobre as emoções era algo reservado a poucos interlocutores de um círculo mais íntimo. Conforme o discurso terapêutico ganhou força na sociedade, cada vez mais as fronteiras entre público e privado se esfacelaram, uma vez que o ambiente profissional passou gradualmente a exigir essa transparência de sentimentos, o famoso 'feedback' (algo como retroalimentação: eu conto o que sinto e você me responde o que sente). Voltaremos a esse argumento em seguida - é importante voltar a Freud e sua tese sobre a origem e importância da separação eu e mundo desde a idade precoce.

Freud (2010), no já mencionado 'Mal Estar na Civilização', detalha a importância dessa distinção Eu-mundo:

\begin{abstract}
É assim que ao Eu se contrapõe inicialmente um "objeto", como algo que se acha "fora" e somente através de uma ação particular é obrigado a aparecer. Um outro incentivo para que o Eu se desprenda da massa de sensações, para que reconheça um "fora", um mundo exterior, é dado pelas frequentes, variadas, inevitáveis sensações de dor e desprazer que, em sua ilimitada vigência, o princípio do prazer busca eliminar e evitar. Surge a tendência de isolar do Eu tudo o que pode se tornar fonte de tal desprazer, a jogar isso para fora, formando um puro Eu-de-prazer, ao qual se opõe um desconhecido, ameaçador "fora". As fronteiras desse primitivo Eu-de-prazer não podem escapar à retificação mediante à experiência. Algumas coisas a que não se gostaria de renunciar, por darem prazer, não são Eu, são objeto, e alguns tormentos que se pretende expulsar revelam-se como inseparáveis do Eu, de procedência interna. (...) Essa distinção [entre o interior, pertencente ao Eu e um mundo externo] serve, naturalmente, à intenção prática de defender-se das sensações de desprazer percebidas ou das que ameaçam. O fato de o Eu, na defesa contra determinadas excitações desprazerosas vindas do seu interior, utilizar os mesmos métodos de que se vale contra o desprazer vindo de fora, torna-se o ponto de partida de significativos distúrbios patológicos.
\end{abstract}

É deste modo que o Eu se desliga do mundo externo.

(Freud, 2010. P 18-19)

A análise freudiana mais uma vez apresenta uma consistência para as reflexões deste campo; ainda assim, há novos fenômenos que possivelmente eram 
inimagináveis na época freudiana. Um deles, efetivamente, trata-se da relação não apenas das dimensões público/privado como espaços, mas como tempo.

Como mencionado anteriormente, um dos fatores que possivelmente causem maior sofrimento no ambiente de trabalho é a fusão entre tempo pessoal e tempo de trabalho, traduzido em jornadas de trabalho intermináveis, estendidas pelo acesso que a tecnologia proporciona. Se há países nos quais o tempo pessoal do funcionário é respeitado, a tendência na contemporaneidade - especialmente nos país de menor renda - é que os profissionais trabalhem e sejam acessados por seus superiores mesmo fora do tempo contratado ou do ambiente formal.

Voltando a Eva Illouz (2007), na Era Vitoriana, o espaço público era a-emocional e o espaço privado, saturado de emoções. A separação entre o público mais formal e o privado emocional gradualmente se dissolveu - o que possivelmente se agravou na medida em que se massificaram os meios de exposição da vida privada pelas mídias sociais. Além dessa dissolução entre público e privado, o Século XX testemunhou uma mudança muito grande especialmente na classe média: um foco intensificado na vida emocional, especialmente no trabalho e na família. Até então, nunca havia na história se investido tanta energia em pensar e, sobretudo, falar sobre a vida emocional. Foi no início desse século que nasceu a narrativa do reconhecimento (do outro), um processo muito influenciado por uma apropriação popular das ideias freudianas. Nessa lógica, uma pessoa fala sobre suas emoções e a partir daí o outro passa a lhe perceber 'verdadeiramente'.

Os Estados Unidos foram o berço dessa preocupação de administradores e psicólogos de Recursos Humanos em "emocionalizar" o ambiente de trabalho. Illouz afirma que o embrião dessa mudança foram as ideias geradas pelas palestras de Sigmund Freud no Clark College em 1909. De sua introdução seminal dos temas psicanalíticos se desenrolaram inúmeras linhas terapêuticas, que fizeram nascer um discurso, o 'estilo emocional terapêutico', uma modalidade de comunicação entre pessoas que enfatiza as emoções e "sentimentos." 
A partir daí as transformações foram muito rápidas. Illouz cita, por exemplo (p. 15), um famoso caso em que a Clínica Mayo foi convidada para fazer intervenções 'terapêuticas' na General Electric, uma das iniciativas para estimular um ambiente profissional mais equilibrado e produtivo. A pesquisadora Stephanie Coonte, que trabalhou esse tema, cita uma mudança interessante de perspectiva: a partir dessa época, as qualidades que os homens precisavam para crescer na indústria passaram a ser predominantemente características do feminino: tato, sensibilidade no trabalho em equipe, aceitação.

Para Eva lllouz, esse movimento teve um reforço em 1946 com a aprovação do "National Mental Act": a partir dessa data, psicólogos receberam autorização da lei norte americana para tratar civis ou pessoas consideradas doentes mentais. Até então, os tratamentos psicológicos eram reservados aos soldados vítimas de traumas decorrentes de combate. Com isso, o discurso psicológico assumiu proporções muito maiores, criando uma série de mudanças em paradigmas na cultura e no ambiente de trabalho. Um deles, por exemplo, foi o conceito do "eu verdadeiro" (true self), possivelmente uma derivação do conceito de self, tão caro à psicanálise de origem inglesa. No mundo Vitoriano, o "eu" sempre era verdadeiro; as emoções eram confidenciadas a uma pessoa privilegiada no espaço da intimidade. A partir do século XX o eu torna-se opaco, depende do reconhecimento pelo outro de minhas emoções e sentimentos ('fale do que sente e poderei the compreender). Na cultura de massa, o "eu verdadeiro", ou eu interior, depende de uma 'escavação' via fala para emergir (versus um 'eu' exterior, uma persona, máscara que encobre a face).

Essas transformações tiveram um impacto profundo no ambiente de trabalho, que com isso se torna um palco para interações cada vez mais emocionais. Além de uma pressão crescente por resultados e produtividade, menos segurança e estabilidade, os líderes têm o papel (muitas vezes implícito) de atuarem como ouvintes e responsáveis por seus subordinados, desenvolvê-los profissionalmente e respeitá-los, mesmo quando a pressão seja insuportável para si. Inclusive, é importante levarmos em conta que muitas organizações funcionam, inclusive, com um discurso descolado da prática: passam aos 
trabalhadores uma imagem do líder sensível e aberto, mas o cobram (e recompensam, estimulam) para extrair o máximo de esforço possível a qualquer custo.

Se o modelo de trabalho na pós modernidade estimula esse 'entregar-se como um cadáver', pode bem ser por uma exploração de um enfraquecimento do Eu - seja via esfacelamento da fronteira público/privado, ou via exaltação da cultura do individualismo. Um autor fundamental sobre a questão do individualismo atual é autor francês Eugène Enriquez: "A renovação do individualismo tem por fim suprimir o sujeito e a vida interior." (2001, P. 46) "Os indivíduos com um "falso self" (Winnicott) ou, sobretudo, com personalidades "as if" serão particularmente apreciados" [nas empresas] (2001, P.46) O sujeito 'individualista' seria separado do coletivo por um ideal de competição que o lança em uma solidão e valida sua combatividade necessária para sobreviver no mundo das corporações. Entregase corpo e alma ao trabalho e perde sua capacidade de se defender contra o fracasso e as metas inatingíveis que Ihe são impostas. Aliás, a solidão parece estar em alta pós anos 2000. Segundo o artigo da BBC News de Barbara Balfour 'Table for one: the rise of solo dining' (Mesa para um: a ascensão do jantar solo) em 2014, um em sete adultos nos Estados Unidos vive sozinho. Em Londres, esse número sobe para quase um terço, enquanto em Paris e Nova lorque são mais de metade dos lares com um só ocupante (acesso em 06 de Agosto de 2014). Isso só reforça a posição de Enriquez sobre a relação solidão / individualismo:

O paradigma individualista não quer nem a mudança social nem a mudança individual profunda. Os próprios indivíduos, únicos responsáveis (se eles fracassam, o erro não cabe à organização nem ao tipo de direção), embora alienados no mais profundo de sua psique, a ponto de "correrem" atrás de sua alienação e a buscarem sempre mais, devem encontrar as melhores soluções para os problemas que lhes são colocados, no quadro de normas extremamente fortes (quando não de dogmas), perfeitamente interiorizadas.

(Enriquez, 2001 - p. 49 - 50) 
É neste mesmo texto que o autor descreve como vê essa substituição do ideal individual pelo 'amor ao trabalho', tema que iremos explorar adiante no texto:

A empresa (ou qualquer outra organização) quer, atualmente, encarnar a "instituição divina". O sagrado laicizado dá ao indivíduo o sentimento de se transcender, através de um projeto a concretizar, um ideal a se realizar, uma causa a defender. Promete-Ihe alcançar um estado não conflitante da psique, uma plenitude que o protege de qualquer trabalho de luto, de perda e sofrimento. (...) Mas os valores gerenciais podem não ser suficientes para responder ao déficit de identificações característico de nosso sistema social e ao mal estar dele resultante. ${ }^{47}$

(Enriquez, 2001 - P. 47, grifo nosso)

O elemento da fusão entre um discurso inspirado no religioso e este 'déficit de identificações' ditas saudáveis seria uma abertura interessante para pesquisa; outros autores como Jean-François Pontégnie marca essa fusão - intencional ou não - entre o religioso e o laico e, mais ainda, entre o mundo da organização privada e o da família.

Qualquer homem, qualquer mulher, está perpetuamente disponível, as noções da duração do trabalho e as horas extras não são poucas, toda a vida faz parte do trabalho, o trabalho é toda a vida e os encontros regulares ao longo dos quais - como nos grupos terapêuticos - nos quais cada um confessa suas fraquezas, ambições e tentações inconfessáveis, e aos poucos a comunidade e o sentimento de pertencimento. "A firma é minha verdadeira família", diz ele, é um refúgio que oferece mais segurança, mais pontos de referência, mais gratificação que a vida familiar, a vida privada.

(Pontégnie, 2017 P. 3)

Enfim, há inúmeros trabalhos - desde o próprio Freud, Arendt até Illouz que marcam precisamente este ponto de tensão que emerge a partir das transformações involuntárias na dinâmica pessoal entre privado e público, seja no espaço da exposição e apresentação de si, seja pela via da manipulação do tempo.

\footnotetext{
${ }^{47}$ Esta ideia tão intensa também ecoa um comentário feito pelo jovem Walter Benjamin, presente no livro de coletâneas 'O Capitalismo como Religião' (2013). No início do ensaio do mesmo nome, o autor afirma: "O capitalismo deve ser visto como uma religião, isto é, o capitalismo está essencialmente a serviço da resolução das mesmas preocupações, aflições e inquietações a que outrora as assim chamadas religiões quiseram oferecer resposta". (Benjamin, 2013. P. 21)
} 
Para concluir, há uma faceta específica dos efeitos nocivos do esmaecimento das fronteiras público / privado no campo do trabalho que deve ser explorada com maior rigor. A percepção da violência no ambiente de trabalho seria, sem dúvida, o exemplo mais grotesco da violação da integridade de um indivíduo por outro (s) no campo do trabalho e, infelizmente, esse fenômeno pode ser visto em diversas modalidades. 
Contrariamente ao que podemos acreditar, a violência é uma conduta de base do ser humano. A não violência é uma conquista cultural.

(Dejours, 2007. P. 14, grifo nosso)

\begin{abstract}
A violência não se transmite na matéria - ela torna-se a própria matéria, confunde-se com ela em seu princípio básico, que é desfazer, morrer, mudar. Para deter a violência, o trabalho humano deve, antes de mais nada, transformar toda matéria num material, o que é muito diferente e já implica controle, pois faz do artesão o índice vivo de uma metamorfose: o barro que ele toca é já o vaso; a lata é já o carro; nada é o que é, ou seja, densidade, resistência e peso puros. A violência, ao contrário, nasce pronta, aceita seu próprio modo de ser sem muito drama, como se tivesse sido assim, e se continua a sua ação - bater, furar ou derrubar - é por impulso, instinto, prazer, o que seja, mas não para cumprir um projeto: o barro ainda é barro, apenas barro, quando o socamos com raiva (não há ideia platônica guiando a ação, aqui).
\end{abstract}

(Ramos, 2017. P. 40)

Christophe Dejours, em seu 'Conjurer La Violence' (Conjurar a Violência, 2007), abre a discussão com uma circunscrição do conceito do que seria a violência. Segundo esse mesmo autor, trata-se de um ponto sensível; se a definição for ampla demais, corre-se o risco de não servir para desenhar propostas de intervenção (especialmente em escala de saúde pública). Se for estreita demais, dificulta a pesquisa e análises quantitativas.

O autor cita a definição de Blandine Kriegel, de 2002: "uma força desregulada que traz ameaça à integridade psíquica ou física, com um fim de dominação ou destruição da humanidade de um indivíduo" (2007, P. 10, tradução livre). Outros autores citados são Elisabeth Brown. Dominique Fougeryollas-Scwebel e Maryse Jaspard, também associando violência ao desejo de dominação: "Os atos violentos são sempre um atentado à integridade da pessoa, quaisquer que sejam a natureza ou os protagonistas. Assim, a violência não se reduz às brutalidades físicas ou sexuais; ela é uma relação de força ou dominação que se exerce pelas brutalidades psíquicas ou mentais". (P. 10) A definição mais simples para Dejours 
seria que "a violência consiste em coagir ou forçar alguém a atuar contra sua vontade pelo emprego da força”. (Dejours, 2007. P. 12) Há algumas maneiras de interpretar o fenômeno da violência - o próprio termo pode ter acepções diversas. O autor Eric Hamraqui descreve algumas dessas possibilidades: "A língua comum distingue as quatro principais acepções do termo 'violência': uma ação (força) exercida sobre alguém com o intuito de fazê-lo (a) agir contra sua vontade pelo meio da força ou intimidação; o ato pelo qual se exerce essa força (serviços, maus tratos); uma disposição natural de expressão brutal dos sentimentos (brutalidade, cólera, fúria, irascibilidade); enfim, a força brutal de um fenômeno natural (sismo) ou de um desejo (impetuosidade)". (Dejours, 2007. P. 301). Outra definição importante que também distingue violência e barbárie é a de José Paulo Fiks e Marcelo Feijó de Mello, que definem violência "tal qual a proposta de Hannah Arendt, como o resultado da luta pelo poder. A violência faz parte das sociedades humanas e é tolerada até certo limite. O esporte pode ser violento, a política, assim como o trânsito e a própria vida urbana. Mas isto não precisa gerar doença. Postulamos que a barbárie é a vertente da violência que pode provocar o transtorno mental. A barbárie pode ser concebida como a vontade de destruir. Seu impacto no paciente seria a percepção de grave e paralisante interrupção da existência." (Fiks, Mello, 2012).

Voltando a Dejours, há uma passagem na qual a violência no trabalho é contextualizada a partir de uma nova perspectiva, baseado na obra de Freud.

Lembremos que para Freud, a "pulsão de agarrar" [pulsion d'emprise] é uma pulsão parcial, que sustenta a atividade pela intermediação da musculatura (1905) e visa a apropriação violenta de um objeto exterior. A pulsão de tomar, colocada a serviço da pulsão sexual, termina no sadismo que toma um lugar importante na vida sexual normal, da mesma forma que o componente masoquista.

Trata-se do ataque à integridade narcísica do outro que caracteriza as relações de objeto estabelecidas pelo perverso narcísico, sob influência de seu "Eu grandioso" (A. Eiguer, 1996). A neutralização do desejo consecutiva à relação da empresa favorece a 'adesão' passiva do sujeito "vítima" às manobras do assédio.

(...) A multiplicação das situações de assédio seria, nesta perspectiva, como um desencadeador das consequências de uma evolução das estruturas de personalidade, organizadas mais e mais frequentemente por uma forma narcísica da busca por um gozo e pela economia da clivagem na sociedade pós moderna ( $R$. Chemama, 2003; C. Melma, 2002). (...) Na psicopatologia do 
trabalho, a busca pela elucidação das causas sintomáticas se apoia em uma análise da relação subjetiva ao trabalho, visto que não se pode atribuir a origem dos transtornos somente à estrutura de personalidade do assediador nem tampouco à da "vítima" do processo do assédio. A psicodinâmica do trabalho propõe recusar as explicações em díades (perverso narcísico / vítima) ou as abordagens descritivas (mobbing) para centralizar a discussão etiológica do assédio moral nos recursos psicológicos da servidão e no consentimento no contexto da dominação social. A instalação do processo de assédio moral implica efetivamente no consentimento dos colegas que constatam e o apoiam, sem se opor, em um desvio das relações de trabalho em sua finalidade (M. Drida, 1999).

(Dejours, Gernet, 2012. P. 84-85, trad. livre)

\section{Esses mesmos autores ressaltam o caráter de repetição do assédio e violência} no ambiente de trabalho.

O assédio moral não é uma novidade no mundo do trabalho. O que é novo, de fato, é primeiramente ligar a solidão da pessoa assediada; em seguida, o reconhecimento social do estatuto de assediado, notadamente a partir do reconhecimento jurídico do fenômeno do assédio, que pode abrir espaço à reparação. (M. Pezé et al., 2003)

(Dejours, Gernet, 2012. P. 85, trad. livre)

Ou ainda, ao discutir sobre este mesmo tema em seu texto 'Trabalho: Usura Mental', na edição de 2000:

(O assédio moral ) Trata-se de uma nova entidade descrita por M. F. Hirigoyen (1998). No entanto o assédio não é uma prática nova no mundo do trabalho. É conhecida desde os tempos após a escravidão, da Antiguidade, até o século XX (...), nas relações entre patrões e 'faz-tudo' (Le Guillant, 1963), os contramestres do desenvolvimento telefônico (Bégoin, 1957), os pequenos chefes das cadeias de construção automobilística (Linhart, 1978), ou os métodos patronais na metalurgia (Doppler, Dejours, 1985). O que há de novo, por outro lado, é a sensibilização das reações contra o assédio no trabalho, em inúmeros países ocidentais. A interpretação da conduta do agressor como um gozo especificamente da perversão é própria da França. Em muitos outros países, são interpretados como uma deriva das formas de gestão (Leymann, 1996) sob o nome de mobbing (sem referência à personalidade de um perseguidor em particular). A marcha, enfim, que visa à criminalização destas condutas, tem sido conduzida conjuntamente por psiquiatras, psicólogos, médicos do trabalho e juristas (Bouaziz, 2000; Meyer, Van Dueren, 2000), constitui uma reação sem precedentes.

(Dejours, 2000. P. 24 - 25. Trad. livre) 
O psiquiatra Bernard Jolivet traz uma definição importante da violência no trabalho: "No campo do trabalho, a violência é o uso deliberado ou não da força física ou moral, direta ou indiretamente, contra uma pessoa ou grupo, ameaçando a integridade física e ou psíquica da ou das pessoas." (In Dejours, 2007 P. 10) Trata-se - e isso aparece ao longo de todo trabalho de Dejours - do quanto e como fazer o trabalhador dar o máximo de si em nome de uma recompensa para o empregador, e o quanto isso pode gerar um ciclo de violência e sofrimento. Evidentemente não podemos generalizá-lo; muitas organizações investem tempo e esforço para regular ambientes de trabalho saudáveis e produtivos.

Daniel Faux e Sophie Delvaux também escreveram um longo estudo sobre violência e trabalho, destinado à categorização do assédio moral e estratégias de prevenção, apoiados pela Universidade de Liége, Bélgica. Eles começam seu texto (2005) reforçando - na mesma linha de Dejours - o quanto falar do indivíduo como alvo da agressão no ambiente de trabalho é um sintoma da degradação de ferramentas de controle das relações de trabalho, como o enfraquecimento dos sindicatos. O foco no indivíduo desvia o olhar do cenário mais amplo: as relações de trabalho são, em sua grande maioria, utilitárias e fundamentalmente desiguais. Dialogando com o já citado trabalho de Eva Illouz (2007), podemos pensar em uma união de elementos potencialmente contraditórios: junta-se um ambiente de trabalho extremamente emocional e no qual os sentimentos são explicitados e quantificados, mesmo avaliados, e condições de trabalho nas quais as exigências são cada vez mais austeras em termos de produtividade e geração de lucro. Além disso, existem instrumentos de análise fina do desempenho e responsabilidade individual. Para se administrar bem, deve-se medir cada ação do trabalhador.

Toda interação humana pode potencialmente carregar alguma medida de violência ou agressividade. A base do trabalho já supõe alguma submissão. "Rousseau sugere que a servidão não pode ser dissociada do trabalho, é a primeira relação com o mesmo. $O$ trabalho conduz primeiro à servidão muito mais que à emancipação do sujeito. [...] A miséria da servidão é o que engendra em 
torno de si a ruína (como mutilação) da subjetividade daquele que consentiu para seu próprio mal e para os outros." (Dejours, 2007. P. 300). A ruína da subjetividade não se dá apenas pelo efeito traumático em si; o mau estar se instala tanto pelo efeito da agressão, mas pela percepção da injustiça. Ainda citando Dejours, "[o que traz maior impacto não é simplesmente o ato violento em si, mas] o encadeamento de injustiça, ausência de reação solidária do coletivo do trabalho, reação violenta que se alcança por um retorno da violência contra a própria pessoa. (P. 59)

Ausência de solidariedade, discursos contraditórios entre si; o trabalho torna-se cenário de sofrimento por esse encadeamento de males. Segundo o autor já citado Eric Hamraqui, uma definição possível é: "injustiça: do latim injuria ou injustitia.[...] um sentimento de ressentimento enquanto tal. É o mal supremo, segundo Platão (Górgias). Ela pode ser a consequência de um excesso do direito, no entanto, nascido da ideia de justiça (do qual a primeira tira sua legitimidade). [...] É essencialmente distinta da violência, embora frequentemente possa se tornar uma fonte da mesma. Ela suscita a justa cólera, a revolta e o sofrimento do sujeito. Sofrimento esse que atualmente é exasperado pela indiferença e inércia dos colegas em razão de sua submissão à dominação simbólica". (In, Dejours, 2007. P. 297) ${ }^{48}$ A vítima de violência no trabalho sofre, mas seu sofrimento não cessa ao final de seu termo no emprego; torna-se trauma, incapacidade de retomar as atividades que exercia antes de sua ruptura.

\footnotetext{
${ }^{48}$ É interessante observar que mesmo entre os primatas há indícios do horror ao sentimento de injustiça. Margaret Atwood (2008) relata um desses estudos a seguir: "A capacidade de avaliar o tamanho de um inimigo ou de uma presa é um traço comum no reino animal, mas, entre os primatas, fazer a distinção correta de quem é o maior e o melhor quando a comida está sendo repartida chega a ser enervante. Em 2003, a revista Nature publicou o relato de experiências desenvolvidas por Frans de Waal, do Centro Nacional de Primatas de Yerkes, da Universidade Emory, e pela antropóloga Sarah F. Brosnan. Para começar, eles ensinaram macacos-prego-decara-branca a trocar pedrinhas por pedaços de pepino. Em seguida, deram a um deles uma uva - considerada mais valiosa pelos macacos - em troca da mesma pedrinha. "Pode-se fazer isso 25 vezes seguidas, e eles se sentem totalmente satisfeitos com os pepinos", disse De Waal. Mas, quando uma uva foi incluída na troca - dando injustamente a um dos macacos um pagamento melhor por algo de igual valor - , os que receberam pepinos ficaram zangados, começaram a jogar pedrinhas para fora da jaula e por fim se recusaram a cooperar. A maioria dos macacos ficou tão zangada quando um deles ganhou uma uva sem motivo que alguns chegaram a parar de comer. (...) O comércio foi ensinado, assim como a taxa de câmbio (pedrinhas por pepino), mas a revolta pareceu ser bem espontânea". (p. 21 - 22)
} 
Efetivamente, a violência no trabalho é um fenômeno pervasivo, difícil de eliminar e uma das maiores fontes de esforço nas organizações contemporâneas. Inúmeras organizações têm investido para eliminar ou facilitar a identificação e casos de violência no trabalho. Para fazê-lo, o primeiro passo foi nomeá-los.

Os fenômenos que mais têm recebido atenção são ligados à violência no trabalho, - mais especificamente na violência entre superior e subordinado - são o Assédio Moral, o Bullying e o Mobbing. Costumam ser estudados por ramos como a Ergonomia (especialmente a francesa) ou Vitimologia, e como afirmou Dejours, não é raro que os três termos sejam usados como sinônimos ou variem de acordo com o país dos autores.

O assédio moral no trabalho, um fenômeno 'tão antigo quanto o próprio trabalho em si', talvez seja dos três mencionados o mais bem conceitualizado. A autora que primeiro chamou atenção a este tema foi a psiquiatra e psicanalista francesa Marie-France Hirigoyen, que definiu esse fenômeno em 1998, em seu livro "Assédio Moral", original de 1998 (Hirigoyen, 2009) da seguinte forma:

Por assédio em um local de trabalho temos que entender toda e qualquer conduta abusiva manifestando-se sobretudo por comportamentos, palavras, atos, gestos, escritos que possam trazer dano à personalidade, à dignidade ou à integridade física ou psíquica de uma pessoa, pôr em perigo seu emprego ou degradar o ambiente de trabalho.

(Hirigoyen, 2009. p. 65).

O assédio moral se baseia em dois fenômenos de "guerra psicológica no ambiente de trabalho: 1) o abuso de poder, rapidamente desmascarável e que pode ser rejeitado pelos funcionários e 2) a manipulação perversa, que causa as maiores devastações". "Não se morre diretamente de todas essas agressões, mas perde-se uma parte de si mesmo. Volta-se para casa, a cada noite, exausto, humilhado, deprimido. E é difícil recuperar-se" (Hirigoyen, 2009. p. 66). É importante para nossa discussão notar que a autora cita o trabalho de Heinz Leimann sobre mobbing e aceita a coincidência dos dois nomes no mesmo fenômeno. 
Hirogoyen atribui a agressão a uma estruturação perversa do agressor, e em seu livro utiliza "violência perversa" como sinônimo. As descrições encontradas em sua obra frequentemente desenham um agressor que de alguma forma experimenta satisfação ou poder em seu ato, uma pessoa que se estruturou e prosperou na carreira através de manipulação. Em alguns momentos, é descrito como um 'hiper-racional', que usa essa violência perversa para ganhar controle sobre uma pessoa ou grupo através dessa destruição das resistências. Isso pode ser alcançado pela recusa em ceder em alguma posição ou decisão profissional, pela intolerância à diferença (gênero, orientação sexual ou religiosa, etnia, etc.) e demais razões pela qual o gestor desejaria excluir uma pessoa de sua estrutura.

Embora Hirigoyen conceitue desta forma, é importante aqui fazer uma ressalva antes de assumir que uma pessoa que cometa assédio moral necessariamente tenha uma estruturação perversa. Muitas vezes - e talvez até a maioria das vezes - trata-se de um modelo de gestão ou mesmo cultura da própria organização. Seja para triunfar contra a competição ou impor respeito, muitas instituições veem o bom (ou boa) líder como aquele ou aquela que extrai o que pode de sua equipe. Há líderes que assediam seus subordinados por que eles mesmos são submetidos a uma pressão para fazê-lo; nesses casos, é essencial identificar o cenário em que o assédio ocorreu e atuar de modo preventivo. Além disso, o assédio moral tem uma dimensão importante de carência na cooperação entre colegas.

O que mudou, aparentemente, é sobretudo a passividade e a ausência de solidariedade da parte dos colegas da vitima do assédio, assim como a profunda transformação do senso de justiça no mundo do trabalho. De forma que as descompensações psicopatológicas consecutivas ao assédio não são somente o resultado do assédio em si, mas a consequência de uma patologia da solidão (que pode ser designada a partir daí pelo nome de patologia da "desolação" em alusão ao conceito que Hannah Arendt forjou para sua análise do totalitarismo). Em outros termos, o agravamento das consequências psicopatológicas do assédio profissional seria ligado (segundo a abordagem da psicodinâmica do trabalho) à desestruturação das estratégias coletivas de defesa contra a injustiça e o sofrimento infringido a um colega. Esta desestruturação não é o termo de um processo "natural" ou "cultural" de resignação, de passividade ou individualismo. Será sobretudo uma transformação em profundidade das formas de dominação social no mundo do trabalho e a um remanejamento das estratégias de defesa em via de se proteger contra os efeitos deletérios do medo, que massivamente fez sua 
entrada no mundo do trabalho com a flexibilização e precarização. Nesta perspectiva, é necessário ser preciso - esse ponto é essencial - que se trata de um deslocamento das estratégias de defesa, e não de um desaparecimento delas.

(Dejours, 2000. P. 25. Trad. livre)

Cabe retornar a Faulx e Delvaux, que, com o apoio de outros autores, desenvolveram 2005 um manual detalhado para intervenções no campo da violência no trabalho. Seu texto foi originalmente publicado sob o titulo "Le harcèlement moral au travail: phénomène objectivable ou "concept horizon"? Analyse critique des definitions des phénomènes de victimization au travail" ( $\mathrm{O}$ assédio moral no trabalho: fenômeno objetivável ou "conceito horizonte", cujo acesso em nossa pesquisa foi feito em 2009). Esse manual contem uma das mais completas revisões sobre o tema assédio moral, incluindo subcategorias como o assédio entre superior e subordinado, entre pares, de subordinado para supervisor, entre outros. É nesse trabalho, por exemplo, que demonstram diferenças essenciais entre autores, como validar o assédio moral pelos efeitos provocados no alvo da agressão. O elemento mais compartilhado seria a duração; a maioria dos autores estudados tem consenso de que só se poderia caracterizar assédio moral uma situação que tivesse uma duração mínima de seis meses, medida conceitual que busca excluir conflitos pontuais ou épocas de pico de trabalho, nas quais o nível de estresse e abrasão fosse inevitavelmente mais elevado.

Segundo Faulx e Delvaux, o sofrimento relacional no ambiente de trabalho seria uma situação na qual uma pessoa ou grupo exprime ou tem ressentimento de mal estar devido a relações vividas em seu local de trabalho ou ligados ao mesmo (tradução livre ${ }^{49}$ ). Os autores inscrevem o fenômeno do assédio moral no campo das "situações abusivas": é o caso em que um indivíduo ou grupo tem comportamentos abusivos em relação a um subordinado, 'comparável ao assédio típico de crianças no intervalo escolar.' Um indivíduo é isolado em função

\footnotetext{
${ }^{49}$ A versão original é "Situation de souffrance relationnelle au travail: situation dans laquelle une personne - ou un groupe - exprime ou ressent un mal-être dû aux relations qu'elle vit sur son lieu du travail ou en lien avec celui-ci".
} 
de uma diferença ou características particulares, sendo colocada em situação incapaz de se defender contra outro que parece impor as regras da relação. Esses autores citam, inclusive, o trabalho de Hirigoyen quando descreve assédio moral como uma conduta abusiva (comportamentos, palavras, atos, gestos, escritos) que possam trazer dano à personalidade, dignidade ou integridade física ou psíquica [no ambiente de trabalho]. (Faulx, Delvaux. 2009)

No texto há muitas variações do tema, mas uma descrição mais sucinta de assédio moral seria de um conflito prolongado em ambiente profissional, no qual o superior isola afetivamente o alvo do assédio, faz comentários depreciativos sobre seu trabalho, omite informações, confere tarefas que possam ser consideradas muito aquém ou além de suas responsabilidades. Enfim, trata-se de uma erosão da estima do trabalhador. O sujeito se percebe desvalorizado e, por algum motivo, incapaz de reagir, encontrar outra saída ou deixar a organização. Em muitos casos, isso é acompanhado por adoecimento psíquico ou físico. Trata-se de uma leitura ampla e extensivamente detalhada no texto, mas que serve para ilustrar a essência do que consideramos assédio moral: uma agressão insidiosa, velada, pouco perceptível no curto prazo e que culmina em sofrimento e angústia.

Uma outra definição detalhada do fenômeno pode ser encontrada no glossário do livro de Cristophe Dejours (Conjurer La Violence), estabelecido por Eric Hamraoui:

Assédio (Harcèlement): em francês, o termo remonta etimologicamente à utilização de um instrumento de arar munido de muitos dentes ${ }^{50}$. Associado no plano moral à ideia de tormento, pressão, destruição, a questão do assédio deve atualmente ser restituída no quadro do conflito entre a lei comum e aquela da Empresa, na qual o Direito do Trabalho, herdeiro do Estado-Nação, se encontra mais e mais esvaziado de seu conteúdo. Conforme as relações entre os indivíduos cessam de ser reguladas pelo direito do trabalho, um vazio se cria. Esse vazio, com a crise de valores que suscita, dá lugar à expressão de relações de força não mediadas nas relações que os empregados estabelecem entre si ou com sua hierarquia em um contexto de exacerbação do individualismo e do definhamento da solidariedade. Daí emergem as novas formas banir aqueles que, ao tentar salvar essa solidariedade, ousam se opor à lei da empresa, à maneira dos

\footnotetext{
${ }^{50}$ Algo como rastelar, em português.
} 
heréticos (de haeresis, capazes de escolher livremente). Banir através do assédio poderia ser interpretado com sendo uma de suas modalidades. (P. 296)

A fetichização do indivíduo tornou possível seu isolamento, seu face-à-face com a hierarquia da empresa enquanto instituição. A situação na qual vivemos tende a ser aquela do esquecimento total (o "esquecimento do esquecimento", em termos heideggerianos) da política, entendida como capacidade de invenção de novas formas de organização e de solidariedade. Inteiramente largado a si e esvaziado de sua substância social, o homem se encontra atualmente mais vulnerável, deixado em um campo do livre surgimento de novas relações de dominação ao seio da EmpresaInstituição.

(Hamraoui, In: Dejours, 2000. P. 299. Trad. livre)

Essa definição relembra a importância de situar os fenômenos de violência no trabalho em seu lugar sócio histórico. Em uma sociedade que valoriza de tal forma o indivíduo, corre-se o risco de falar somente de casos isolados de violência, sem pensar nas condições do trabalho que podem fazer mal a todos. Como apontou Dejours, em tempos nos quais a avaliação de desempenho é gradualmente mais individualizada e passível de rápida medição - especialmente por avanços tecnológicos como crachás que gravam e monitoram o movimento dos funcionários ou leitura automatizada de mensagens privadas - a ausência dos mecanismos de solidariedade entre funcionários torna mais evidentes e destrutivos os fenômenos que chamamos sofrimento no trabalho.

Os dispositivos de Direito também buscam se adaptar a essas novas demandas. Em seu texto "Assédio Moral: violência ou dominação? Saúde mental no trabalho e ação" (In Dejours, 2007), Jean-Claude Valette traz uma perspectiva da evolução desse debate na França:

A LMS (Lei de moderação social) de fevereiro de 2002, atualizada em Janeiro de 2003, [define] assédio moral como sendo: uma degradação das condições do trabalho suscetível de se tornar uma ameaça (para a empregado) aos seus direitos, sua dignidade, de alterar sua saúde física ou mental, ou comprometer seu futuro profissional. 
Trata-se de uma dimensão bastante pragmática do assédio moral, mas que o autor irá enriquecer justamente definindo qual seria o efeito provocado pela agressão. Trata-se de uma outra vertente de debate do tema, que teve como pioneira a autora Lyn Quine ${ }^{51}$ (1991), do Reino Unido, em seu trabalho com Enfermeiras que sofriam assédio moral e, em especial, tomava como o indicador principal os efeitos provocados no indivíduo.

\begin{abstract}
Na dimensão 'efeito', [...] o assédio moral ocupa a função de um sintoma, um compromisso que tende a resolver um conflito invisível e incompreensível nas relações sociais de trabalho.

Uma relação psicológica individual colocando em causa principalmente a estrutura da personalidade que se torna frágil. [...] $\bigcirc$ sofrimento é individual; não é a estrutura da personalidade que é, em primeira estância, responsável. É um modo de relacionamento social no trabalho produzindo relações intersubjetivas perversas, que geram o sofrimento e descompensação. (281 - 282) Referindo a "efeito", me situo na hipótese de um registro defensivo, no sentido da Psicologia do Trabalho, no qual os trabalhadores recorrem para se protegerem da dominação na organização do trabalho.
\end{abstract}

(Quine,1991. P. 283. Trad. livre)

Essa definição nos parece especialmente interessante, pois estabelece algo como uma dialética entre a estruturação psíquica do sujeito anterior ao tempo do assédio, e uma falha desta organização ao não buscar uma autoridade ou mesmo regras para reagir à violência. Trata-se de uma abordagem similar à de quando sugere que 'vítimas' do assédio teriam uma personalidade 'parcialmente melancólica, aliada a uma vitalidade muito grande' Hirigoyen (2009, P. 160).

Ambos exemplos - Quine e Hirigoyen - trazem, no entanto, uma problemática central no tema da violência no ambiente de trabalho. Uma crítica a essa abordagem é o reducionismo em estereotipar e, mais ainda, generalizar que uma pessoa que comete assédio necessariamente seria um perverso. A este respeito, Dejours é um dos autores que reforça a importância de evitar a explicação de que 'todos os que cometem assédio são perversos' ou que a responsabilidade

\footnotetext{
${ }^{51}$ Um dos artigos em que a autora estuda os efeitos da violência é o "Workplace bullying in Nurses", publicado no Journal of Health Psychology, em 1991. Trata-se de uma das primeiras autoras que propõe examinar o assédio moral com base nos efeitos que a experiência provoca no agredido (a).
} 
seria apenas do sujeito que sofre. Em seu texto 'Trabalho, usura mental', Dejours afirma:

\begin{abstract}
A interpretação do assédio [...] pela via da perversão na personalidade do agressor, poderia bem ser um sintoma; pode se dizer, uma formação de compromisso testemunhando a vitória esmagadora das novas formas de organização, de gestão e administração face a uma vontade de agir, reagir ou resistir, na qual a potência coletiva é muito afável, até compromissada [...]

[...] O sujeito está sozinho ao sustentar uma relação crítica da realidade do trabalho, relação crítica muitas vezes racional - frequentemente banalizada ou desabonada por sua própria comunidade - de pertencimento, que se desestabiliza e faz dotar de razão e cria, no fim das contas, a falha psicopatológica ou psicosomática: o ataque à sua identidade. Efetivamente, à partir desse momento, o sujeito está clinicamente em um estado pré-mórbido, uma forma de patologia da solidão, o que designamos seguindo o nome da patologia da desolação em alusão ao conceito de Hannah Arendt para sua análise do totalitarismo], da qual ele tenta se defender somente por seus próprios meios.
\end{abstract}

(Dejours, 2008. P. 286. Trad. livre)

Nesta perspectiva mais ampliada, o assédio não seria apenas um fenômeno provocado por um indivíduo perverso, mas ainda como um efeito sócio econômico, um dano colateral que acompanha as novas formas de organização do trabalho. O essencial é escapar a ambos polos de estereótipo: tanto condenar a estigmatização do indivíduo que sofre assédio como vítima (e, assim, submisso, fraco, débil e indefeso) como refutar a simplicidade de se atribuir o fenômeno da violência apenas à satisfação perversa de um agressor. Já mencionamos anteriormente (P. 100) o trabalho de Lise Gaignard, que justamente questiona esta caracterização do assediado como 'vítima'; trata-se de uma das teorias que chama a atenção à potencial relação da queixa (ou demanda) de assédio moral à culpabilidade inconsciente. Um sujeito que considere desonestas ou danosas suas atribuições, poderia desenvolver uma culpa inconsciente, que, por sua vez, promoveria um mal estar moral de tal forma insuportável que pode levar o sujeito a se submeter, tolerar ou a inconscientemente mesmo buscar caminhos para envolver-se em uma situação de violência no trabalho.

Se partimos do princípio de que aquilo que se convencionou chamar de "assédio moral" possa engendrar uma "crise" da culpabilidade, dada a um compromisso com um trabalho que seria reprovável, e 
com os mecanismos escapando ao próprio agente, torna-se necessário para o terapeuta conhecer bem as organizações do trabalho. Será então necessário que o terapeuta ajude seu paciente a enxergar naquelas situações de individualização ou falsificação, para que possa se desfazer do vínculo de culpabilidade inconsciente nos quais se encontre preso.

O que podemos reter do laço entre assédio moral e as novas organizações do trabalho é que se trata de trabalho efetuado sem pensar, seja em virtude da intensificação de tarefas, seja por uma perda de sentido, seja pelo retorno do mal como bem, ou por todas essas razões juntas. As tarefas deletérias serão então aquelas que comportariam um impedimento de pensar nas questões éticas como condição necessária para obter o engajamento dos agentes". (P. 166 - 167)

Podemos tratar da agressividade, do desrespeito, da irritação generalizada dos trabalhadores entre si como sinais de consciência pesada, como se fosse um preço metonímico a pagar para o SuperEu.

(Gaignard, In: Dejours, 2007, P. 168)

Trata-se de uma visão original sobre o fenômeno; embora haja uma dimensão mais ampla e compartilhada, influenciada por economia e contexto histórico, também existe a dimensão do indivíduo. Nesta esfera do Eu e suas relações com o mundo interior, o sujeito se vê exaurido moralmente por fazer um trabalho que considera detestável ou irrelevante, e extravasa essa frustração e violência contra os outros ou contra si. Essa mesma autora propõe estratégias com as quais o analista poderia contar para tratar esses casos. A base que Gaignard utiliza é a do tratamento dessa culpa inconsciente superegoica pelo retorno de uma narrativa de continuidade, que traria à tona esse mal estar provocado pelo trabalho desgastante.

[um dos papeis do terapeuta ou psicanalista seria de questionar] o que faz exatamente, e sobretudo como o faz. As respostas são terríveis: uma atendente de uma casa de repouso que conta que havia uma pessoa que alertava o restante da equipe quando um membro da família do internado chegasse, para, só então, trocar a pessoa, arrumar seu quarto, etc; um engenheiro obrigado a falsificar relatórios a respeito da segurança ambiental em grandes empresas; uma enfermeira de um serviço de atendimento de saúde mental contou de um médico que a pedia para passar os horários de trem para pacientes com uma demanda suicida. (P. 167) O mais importante é que essas pessoas não procuraram ajuda para trabalhar essas questões, mas por terem sido submetidas a um assédio moral perverso, conduzido por uma pessoa específica contra elas".

(Gaignard, In: Dejours, 2007. P. 168. Trad. livre) 
Essa proposta convida o analista a esse papel de ajudar o sujeito alvo de assédio (e culpado de outras infrações) a rever seu papel em sua própria trama. Outra forma de dizê-lo seria a do já citado Jean-Claude Valette, que afirma que o papel dos 'interventores' (médico, sindicalista, inspetor do trabalho, mas que poderíamos extrapolar para o terapeuta ou analista) é o de ajudar o sujeito a 'refazer os laços perdidos, ou seja, começar a historicizar, re-situar os eventos em uma temporalidade em relação à situação de trabalho, o processo no qual está preso, e assim ajudar a se (re) mobilizar psiquicamente". (Dejours, 2007, P. 290)

O analista ou terapeuta tem como uma de suas tarefas ajudar seu cliente a restabelecer os laços com sua própria narrativa e reconhecer o mal que promoveu a si e ao outro. Poderíamos até afirmar que esse caminho ajuda a vítima de assédio o mesmo o assediador a repensar suas escolhas e se reposicionar como sujeito, sair da posição de vítima ou de algoz ao reconhecer seu papel como alguém também sensível à e capaz de violência. Trata-se de uma proposta para tratar o assédio moral que deixa de lado a relação vítima/agressor e busca a saúde via responsabilidade individual e novas escolhas profissionais que conduzam a menos sofrimento.

Trata-se de uma proposta ousada e original, mas será que pode ser aplicada a qualquer situação de violência no trabalho? Nossa hipótese é que não, e essa separação dependeria de uma diferenciação entre dois conceitos bastante comuns na contemporaneidade. Como propor uma diferenciação entre Assédio Moral e Bullying?

O assédio moral nos parece ser relacionado a uma forma mais sutil de violência, mais gradual. Se no assédio a violência é psicológica ou baseada em diminuição ou ampliação excessiva das tarefas, isolamento e ataque moral, no bullying é mais explícita, mais direta. Não estamos falando da insegurança, perda de autoestima como no assédio; aqui falamos em um episódio de ameaça ou mesmo de violência consumada. No bullying o medo não é da própria 
incompetência, mas está fora, condensado em uma figura real. Evidentemente, os dois casos frequentemente caminham juntos; o intimidador exerce uma tensão psicológica, mas neste caso tudo acontece de uma forma muito evidente, no espaço público. Quando transpomos para uma realidade de trabalho, formase um cenário no qual uma pessoa sofre ameaças constantes ou mesmo é vítima de ataques físicos ou psicológicos.

O já citado manual de Faulx e Delvaux (2009) traz uma definição de bullying mencionada em um texto de 2003 de Einarsen, Hoel, Zapf \& Cooper que condiz com o que vemos na literatura e cultura. Bullying no trabalho significa assediar, ofender, socialmente excluir alguém, afetando negativamente suas tarefas de trabalho. Para que seja chamado de bullying (ou mobbing) (...) deve ocorrer repetidamente e regularmente (por exemplo, de forma semanal). Bullying é um processo crescente; um conflito não pode ser chamado de bullying se for um evento isolado ou se ambas partes têm 'forças' iguais.

Duas modalidades de bullying estão muito evidenciadas desde 2010: o bullying em ambiente escolar e o cyberbullying. Podemos pensar em ao menos uma diferença e uma semelhança fundamentais entre o bullying na escola e no ambiente organizacional. A principal diferença, tem a ver com escolha: no limite, um adulto é mais livre para escolher em que empresa ou ambiente deseja ou suporta trabalhar. A criança, por outro lado, depende muito da aprovação e apoio dos guardiões e mestres para fazer escolhas (mudar de escola pode alterar toda rotina da família, mudar de sala pode depender de aprovação da Direção, e assim por diante). Podemos pensar que o alvo de bullying na escola está muito mais indefeso que um adulto.

A semelhança que podemos identificar entre bullying na escola e na empresa diz respeito à intenção: é muito frequente que o bullying escolar seja uma criança que foi abusada no passado. Seu ato de agressão é uma repetição do que já sofreu antes, e por isso tenta ganhar respeito dos colegas se impondo como mais forte que outra criança (por exemplo, atormentando um colega mais fraco). O bully, no limite, é uma criança que tem medo e por isso recorre a essa postura covarde. Nas empresas, esse elemento pode ser um grande catalisador: autores 
que trabalham com agressores como a já mencionada Laura Crawshaw (2007) afirmam que a maior motivação dos bullies organizacionais é justamente o medo. O líder que ataca tem medo de falhar, medo de não ser capaz de dar resultados sem recorrer à intimidação. Os relatos convergem para pensarmos que o líder agressivo atua desta forma por acreditar não ter outro recurso para trazer os resultados pelos quais é pressionado. A organização geralmente desaprova essa conduta; é comum ver o bully organizacional ameaçado na estrutura, manchado por constantes disputas por poder ou por falta de reconhecimento de seu líder ou colegas de trabalho. Ainda assim, o paralelo se mantém: assim como a criança que ataca o colega mais fraco por insegurança ou medo, o líder que agride também pode ser visto como alguém que teme intensamente falhar (e, de certa forma, já falha pela sua postura).

A segunda modalidade, do cyberbullying, não chega a ser uma variação do fenômeno em si. A diferença é apenas nas ferramentas utilizadas: em lugar de intimidação física, ela é feita por meios digitais como e-mail, redes sociais, websites e ambientes virtuais em geral. A maior diferença, neste caso, é que o processo é silencioso; o bully fica protegido pela virtualidade de seu ataque, que não é tão evidente ao grupo como quando praticado no mundo físico. Infelizmente, essa aparente limitação pode fazer do fenômeno contagioso; não é incomum vermos situações de cyberbullying que terminam em mobbing por vias digitais. Há o caso famoso nos Estados Unidos de Megan Meyer, uma jovem de 13 anos que suicidou após ser degradada em redes sociais pela mãe de uma colega que morava há quatro casas da sua e a atacou sob uma identidade falsa de um jovem de sua idade.

Uma terceira variação sobre o tema é o chamado Mobbing; embora seja utilizado como sinônimo dos dois anteriores para muitos autores, é um conceito antigo, estabelecido pelo etnólogo Konrad Lorenz e posteriormente recuperado pelo médico e psicoterapeuta sueco Peter Heinemann. Sua definição veio do termo inglês mob (horda ou turba): um grupo que promove a barbárie com o objetivo de expulsar ou destruir um indivíduo. O trabalho de Heinemann começou na década de 1960, aplicando esse conceito a crianças que sofriam violência no 
ambiente escolar, publicando seu primeiro livro sobre o tema em 1972. Com o tempo, expandiu esse conceito ao ambiente de trabalho, mantendo o mesmo termo (mesmo em situações entre duas pessoas).

[Mobbing é] um encadeamento de comportamentos hostis direcionados a uma pessoa de maneira cotidiana e durante um longo período que conduzem a impotência e com riscos elevados de exclusão.

(Leymann, 1996).

Heinz Leymann define mobbing como "terror psicológico que envolve comunicação hostil e antiética de forma sistemática por parte de um ou mais indivíduos dirigida a um indivíduo." O alvo é conduzido a uma posição indefesa e sem saída, resultando em sofrimento mental, psicossomático e social. (Leymann, 2011) Embora o elemento de isolamento já esteja presente no assédio moral, o termo mobbing traz na definição de Leymann um caráter mais agressivo, grupal, cujo objetivo é a expulsão. Se no assédio moral o estresse seria mais cumulativo e destinado a incapacitar o subordinado, aqui a ação é mais direta e visa expulsão do grupo, rejeição. A descrição do fenômeno na relação hierárquica pode ser pensada em um cenário no qual um sujeito é agredido pelo superior e o grupo passa a hostilizá-lo com medo de sofrer da mesma forma.

Trata-se, enfim, de um grupo movido por medo, horror ao diferente ou identificado com um líder destrutivo. Se o alvo não tinha alguma característica imediatamente detestável, aos poucos vai solidificando a imagem que seus perseguidores o atribuem (frequentemente fraqueza, covardia ou o oposto, obstinação e arrogância). A violência prolongada acaba por validar suas próprias premissas falsas, e ao final só pode haver a ruptura pelo insuportável da situação. Em suma, os elementos chave do mobbing são justamente a exclusão, isolamento, ameaça de destruição.

Trata-se, enfim, de um movimento contemporâneo de repúdio à violência no ambiente de trabalho. Inclusive, existem propostas sobre como prevenir ou minimizar esse elemento Para Dejours (2007), a melhor alternativa seria fomentar o que chama de atividade deôntica, a criação de regras que permite aos 
trabalhadores combater a violência. (2007. P. 80). É pela atividade deôntica que a cooperação se firma como a forma mais simples e potente de combater a violência no ambiente de trabalho sob o estabelecimento de regras que irão substituir violência por colaboração e solidariedade. "O que permite prevenir a violência é fundamentalmente a discussão, a palavra, a escuta, o agir comunicacional. A violência é uma das manifestações maiores de patologia da comunicação". (Dejours, 2007. P. 81)

Mais uma vez, a ressalva deve ser feita para pensar não apenas nas relações interpessoais, mas nas ferramentas de controle - ou falta deste - nas próprias organizações; para Dejours, por exemplo, a avaliação individual de desempenho seria uma via para estimular a competição agressiva e a eliminação da colaboração nas organizações ${ }^{52}$. Dejours afirma em seu texto 'Violência ou Dominação?' que "as novas formas de organização do trabalho e a direção das empresas não apenas utilizam a violência como instrumento de dominação, mas [ao mesmo tempo] determinam uma atividade intensa e coerente de contenção da violência. Os instrumentos de dominação não passam só pela violência, mas pela formação da tolerância à injustiça e ao sofrimento que preconiza o aumento da violência no trabalho. Esses instrumentos não violentos são essencialmente organizados em dispositivos baseados em princípios e meios rigorosos [...] de "distorção comunicacional". [É] determinante na formação da "dominação simbólica", que não seja não violenta, mas que contribua para conter a violência nos ambientes de trabalho". (Dejours, 2007. P. 283)

Em suma, nossa hipótese é a de que de todos os conceitos já apresentados até aqui, a violência no ambiente de trabalho e suas múltiplas facetas - Assédio Moral, Bullying e Mobbing - talvez estejam estre as mais pesquisadas e bem mapeadas. Diversas organizações têm se dedicado a prevenir tais fenômenos, assim como muitos pesquisadores têm investido em desenvolver estratégias para

\footnotetext{
${ }^{52}$ A violência é uma das expressões comuns do sofrimento dito social nas [populações do setor industrial, terciário, serviços e agricultura, especialmente privadas do trabalho]. No mundo do trabalho, as transformações importantes da organização do trabalho via as novas tecnologias, a flexibilização do emprego, os métodos de avaliação individualizada de performance e as certificações de qualidade geram novas formas de sofrimento e patologia mental. (Dejours, 2007. P. 17-18 Trad. livre)
} 
prevenir, tratar e reagir a este fenômeno eminentemente humano, e tão antigo nas dinâmicas de trabalho. 
O animismo havia dotado a coisa de uma alma, o industrialismo coisifica as almas. O aparelho econômico, antes mesmo do planejamento total, já provê espontaneamente as mercadorias de valores que decidem sobre o comportamento dos homens. A partir do momento em que as mercadorias, com o fim do livre intercâmbio, perderam todas as suas qualidades econômicas salvo seu caráter de fetiche, este se espalhou como uma paralisia sobre a vida da sociedade em todos os seus aspectos. As inúmeras agencias de produção em massa e da cultura por ela criada servem para inculcar no indivíduo os comportamentos normalizados como os únicos naturais, decentes, racionais. De agora em diante, ele só se determina como coisa, como elemento estatístico, como success or failure.

(Adorno e Horkheimer, 1985. P. 40)

Uma das bênçãos do trabalho é que só ele torna possível sentir o gozo de não fazer nada. Kant qualifica o cansaço após a jornada de trabalho como um dos maiores prazeres dos sentidos. Ócio sem trabalho é tortura.

(Benjamin, 2013. P. 161)

O tema do senso de propósito no trabalho é tão antigo quando difícil de abordar. Afinal, a própria ideia que alguma experiência humana poderia ser provedora de sentido em si mesma é muito mais próxima do campo da teologia religiosa do que de um campo de tal forma 'mundano' como o trabalho. Efetivamente, desde o debate filosófico que analisava a contemplação em oposição à ação algum grau de desconexão entre o fazer e a reflexão pura e a dificuldade de alcançar o sublime por meio das atividades do cotidiano já se discutia. Nessa perspectiva, o trabalho dificilmente seria associado à aquisição de um propósito, especialmente $\mathrm{o}$ trabalho que fosse motivado por necessidade (como mencionado, Hannah Arendt já apontava o quanto seria impensável para uma pessoa anterior à Revolução Industrial a conexão entre trabalho e felicidade). Por outro lado, qualquer atividade profissional proporciona muito mais que a simples compensação material. Efetivamente, a vida profissional proporciona tamanho 
apoio à identidade do adulto que mesmo que possível seria inviável separar a identidade profissional e pessoal.

Neste sentido, muitos pesquisadores foram conduzidos a se perguntar qual é a lógica do que nos motiva, em especial em relação a contratos psicológicos. Afinal, o que faz uma pessoa escolher uma profissão em um determinado momento de sua vida? A ciência dos contratos psicológicos foi explorada por autores como Rousseau (1995), Guest (1998), Roheling, (1997), Sutton and Griffin (2004) e estabelece uma proposta de conexão entre as escolhas profissionais e expectativas individuais ${ }^{53}$.

Contratos psicológicos seriam um conjunto de acordos sempre em transformação baseados em expectativas explícitas e implícitas tanto de indivíduos como organizações. Quanto mais claros e alinhados os termos e mais houver harmonia entre os interesses das partes, mais construtiva será a relação de trabalho. No entanto, o que aconteceria se essas expectativas fossem desconhecidas para o próprio indivíduo, ou ainda pior, se fossem inalcançáveis? Neste ponto, também é essencial lembrar o comentário de Daniéle Linhart assim como no trabalho de Christophe Dejours - quando ressalta justamente o que considera ser a natureza do trabalho em oposição ao trabalho 'prescrito'. Se fôssemos estabelecer um paralelo, poderíamos justamente estimar que a tese de Rousseau se situa exatamente na tentativa de conter, criar uma contenção que impeça o trabalho prescrito de se tornar o trabalho 'real' - ou o 'real do trabalho' dor psicodinamistas do trabalho; a diferença entre os autores é justamente a aposta de Rousseau na possibilidade de estabelecimento de tais acordos, desde

\footnotetext{
${ }^{53}$ Uma leitura fundamental neste tópico é o debate entre Denise Rousseau e David Guest, presente em artigos como o de Rousseau "Psychological Contracts in Organizations: Understanding Written and Unwritten Agreements" ('Contratos Psicológicos nas Organizações: Entendendo Acordos Escritos e Não Escritos',1995), Rousseau e Dabos' "Mutuality and Reciprocity in the Psychological Contracts of Employees and Employers" ('Mutualidade e Reciprocidade em Contratos Psicológicos de Empregados e Empregadores', 2004) e suas réplicas por David Guest "Is the Psychological Contract Worth Taking Seriously?" ("Vale à Pena Levar a Sério o Contrato Psicológico?', 1998), 'On Meaning, Metaphor and the Psychological Contract: A Response to Rousseau" ('Sobre Sentido, Metáfora e o Contrato Psicológico: uma Resposta a Rousseau', 1998), "The Psychology of the Employment Relationship: An Analysis Based on the Psychological Contract" ('A Psicologia do Relacionamento de Emprego: Uma Análise Baseada no Contrato Psicológico', 2004).
} 
que bem mediados, dialogados e oficializados pela instituição. Mas afinal, quais seriam as dificuldades do indivíduo em definir claramente seus termos?

Sobre o tema, façamos uma breve digressão. Na revista 'Opção Lacaniana Online', (Março de 2017) o psicanalista francês Éric Laurent foi questionado quanto à posição da psicanálise em relação à aliança entre ciências e terapias cognitivo-comportamentais, especialmente no tocante à promessa da 'felicidade e bem estar'. O autor deu a seguinte reposta: "Todo mundo quer ser feliz. Essa é uma demanda que se tornou legítima após o lluminismo, no século XVIII, quando, contrariamente à religião, o próprio pensamento abriu a possibilidade de uma felicidade terrestre e não somente uma salvação eterna. A partir do lluminismo, o primeiro Estado moderno, a América, incluiu no início de sua constituição a busca da felicidade como um pedido legítimo que um Estado moderno deve poder oferecer aos seus cidadãos. Então, depois do século XVIII, todo mundo busca sua felicidade. No entanto, o resultado disso não é satisfatório. Após dois séculos de organização do Estado Moderno construído em torno do welfare, vimos o quanto cada um faz para não obter a sua felicidade, o quanto cada um, em sua vida, encontra um certo número de impasses que regularmente causam impedimentos. Então, conhecemos ao longo desses dois séculos diferentes atitudes para entender por que é que os humanos não encontram a felicidade. Uma dessas variações é "porque eles têm maus hábitos. Então, vamos mudar seus hábitos e comportamentos". (Laurent, E. 2017. P3) Esta entrevista, concedida em outubro de 2008 serviria como uma ótima introdução ao tema crescente do propósito nas organizações e, mais ainda, a uma transformação do uso do conceito de propósito.

À sua proposta de que uma 'mudança de hábitos' como uma via de se eliminar a infelicidade da contemporaneidade, poderíamos propor ainda um novo elemento, presente por exemplo no texto de Daniéle Linhart; a ideologia de introdução de conceitos como propósito nas organizações fariam parte de um movimento de apropriação da criatividade e, em especial, de um vazio identitário em um número cada vez mais crescentes de indivíduos, à qual poderia se somar 
a apropriação do senso de propósito ${ }^{54}$. Trata-se efetivamente de algo difícil de determinar, mas que não aparece sem consequências - certamente, é uma via excelente de captura do desejo, das identificações e, mais ainda, da criação de um vínculo que repõe compensações cada vez mais escassas ou desiguais por um sentimento mais ampliado de vínculo que aquele predominantemente ou mais puramente intelectual. Não apenas toda a subjetividade encontra-se implicada e aplicada ao trabalho sem necessariamente uma lealdade correspondente nas organizações privadas; o próprio senso de pertencimento que poderia ser reservado à sociedade, à família ou à própria espiritualidade passa a ser repatriado ao ambiente profissional.

"Faça o que ama e encontrará a felicidade", ou sua versão (semi) oficial: "Do what you love, and you'll never work another day in your life", é uma frase estranhamente atribuída tanto a Confúcio, Mark Twain, Mark Anthony, e repetidas inúmeras vezes tanto por adesivos motivacionais, consultores e empresários de todos os segmentos. E, como mencionado anteriormente, traz problemas semelhantes aos encontrados em uma análise das ideias como o reconhecimento ou autonomia.

Se aplicarmos um olhar mais rigoroso com base nas ideias psicanalíticas, por exemplo, o reconhecimento, no limite, poderia ser a representação no campo social de uma busca pela reunião ao objeto de amor primordial - a mãe, o pai, as relações objetais do início da vida. Neste sentido, especialmente por uma referência ao Super Eu (ou ao Eu Ideal, se tomarmos uma linha do campo freudiano), o reconhecimento, em sua plenitude, é impossível. A fantasia de um reconhecimento incondicional e irrestrito é, enfim, uma demanda de amor; neste sentido, não haveria limites para que as fantasias e complexos sejam saciados. O mesmo ocorre com o conceito de autonomia no trabalho: trabalho é, em alguma medida, submissão. Seja a um chefe, ou a um cliente ou mesmo à própria necessidade de compensação financeira, o trabalhador seria necessariamente

\footnotetext{
${ }^{54}$ Exemplos podem ser encontrados tanto em livro mais recente - 'Trabalhar sem os Outros' como em outros textos como "Daniéle Linhart, La comédie humaine du travai. De la dés humanisation taylorienne à l'a sur-humanisation managériale" (2015) de Marc-Antoine Pencolé, comentando o livro de 2015 da autora.
} 
um assujeitado, não-livre e submetido ao próprio trabalho ou à necessidade em si. Violência no trabalho também pode ser pensada no plano da agressividade, uma das características mais elementares das pulsões humanas. Desta forma, nem o ambiente de trabalho e ou qualquer outro ambiente no qual há convivência humana seria isento de algum grau de violência...

Entretanto, mesmo com ressalvas e críticas, os demais temas tratados neste texto ainda se sustentam com mais consistência que o senso de propósito. Toda tradição filosófica desde Platão a Heiddeger desmonta a simplicidade desta ideia; para Heidegger - de modo muito simplista e cru - o 'propósito' da experiência humana seria um falso problema. O ser-aí, o dasein, necessariamente é um serpara-a-morte. Neste sentido, poderia se argumentar que o propósito, se houver algum, é preencher a lacuna entre o ser-no-mundo e o ser-para a-morte; sobreviver e buscar uma existência com algum grau de crítica e fruição já serviriam como propósito, e a transcendência possível viria da Arte, do belo, enfim, do sublime. Assim, o fenômeno de se atribuir ao trabalho a responsabilidade de busca pela felicidade, sentido ou propósito, seria um capricho da modernidade (e seu exagero seria, assim, uma característica da hipermodernidade).

A própria ideia que alguma experiência humana poderia ser provedora de sentido em si - algo que os teóricos marxistas já adiantaram há anos na forma do fetichismo dos meios ou mesmo a alienação - é muito mais próxima do campo da teologia religiosa do que de um campo tão mundano como o trabalho. Efetivamente, cabe à reflexão filosófica a análise da contemplação em oposição à ação, assim como a desconexão entre o fazer e a reflexão pura. Essa 'importação' do propósito ao mundo das relações de trabalho não acontece em um vácuo; parte deste processo segue a lógica motivada pela sociedade de consumo. Valores como 'propósito', 'engajamento', 'criatividade' e 'inspiração' são exemplos de elementos que historicamente pertenciam à experiência religiosa ou transcendental que ressurgem em uma versão simplificada para servir à expansão inédita do alcance do trabalho (e das técnicas modernas de gestão). Se historicamente o propósito pertencia ao campo do religioso, do retorno do 
homem a Deus e à purificação da alma, este conceito ressurge para vincular ainda mais fortemente o indivíduo à organização, além de responsabilizar o trabalhador por sua própria dedicação ao trabalho. Cria-se, enfim, um mito de um trabalhador que encontrou seu propósito, esse 'herói prometeico moderno ${ }^{55}$, que carrega consigo sinais de sucesso financeiro, social e uma satisfação ímpar com seu trabalho, em oposição ao indivíduo em conflito, frustrado por não ter buscado com tenacidade ou coragem suficiente a seu propósito pessoal. Tratase de um fenômeno semelhante à inspiração ou criatividade; antes atributos do divino, e do caráter de 'escolhido' do artista ou do 'divino' presente na figura do Rei ('hierós', que originaria posteriormente o termo 'hierarquia'), agora são colocados como uma habilidade mensurável, com valor de mercado, e posta à serviço de um aumento incessante das técnicas para geração de capital.

Apesar disso, o uso do propósito (ou mesmo do "amor") na literatura de auto ajuda é cada vez mais comum. Nesta esfera, não só o propósito é algo simples e tangível, mas não faltam meios de alcançá-lo com facilidade. Para citar um exemplo, vejamos um trecho do livro "Ache seu Porquê: um guia prático para descobrir propósito para você e seu time" (Find your Why: A Practical Guide for Discovering Purpose for you and your Team) - complemento de outro livro, "Comece pelo Porquê" - do best-seller Simon Sinek (co-escrito ou escrito pelos colaboradores David Mead e Peter Docker). Sinek, "autor de 5 livros, consultor organizacional e palestrante motivacional”, inicia sua obra da seguinte forma:

Plenitude é um direito, e não um privilégio. Cada um de nós tem o direito de sentir-se realizado [fulfilled] pelo trabalho que fazemos, acordar sentindo-se inspirado para ir trabalhar, seguro quando estamos lá e voltar para casa com a sensação de que contribuímos para algo maior que nós mesmos. A plenitude não é uma loteria. Não é um sentimento reservado para um pequeno grupo de sortudos que podem dizer, "eu amo o que faço.

O conceito do PORQUÊ (WHY) é uma jornada pessoal profunda, que nasceu da dor. Descobri a ideia quando havia perdido qualquer paixão pelo meu trabalho. Os conselhos que recebia também não ajudavam: 'faça o que você ama', 'Encontre o que te dá prazer', 'Seja apaixonado'. Todos muito acertados, mas difíceis de colocar em prática. Eu concordava com todos em teoria, mas não sabia o que

\footnotetext{
${ }^{55}$ Referência à ideia de Walter Benjamin, apresentado pela prof. Olgária Mattos em um texto já mencionado.
} 
mudar. É por isso que o PORQUÊ foi e continua sendo uma força tão profunda em minha vida.

(Sinek et al., 2017. P. vii-viii (prefácio), trad. livre)

O texto de Sinek é singular; ele inicia com uma ideia bastante atrativa para uma sociedade adoecida pela universalidade da produção e consumo, um ourobouros mordendo sua própria cauda, no ciclo infinito de produtividade incessante para sustentar um consumo infinito. Plenitude, a experiência plena marcada pelo fim da falta - literalmente em inglês 'cheio até o topo', 'todo cheio'. Em uma época na qual o empuxo ao consumo e à geração e consumo de commodities é interminável, "24/7" para citar o já mencionado Jonathan Crary (Crary, J. 2016), o desejo pela plenitude é algo imensamente irônico, especialmente pelo seu caráter paradoxal. Não apenas a existência humana se orienta pela falta (que gera o desejo, é condição necessária para o desejo); a plenitude é um 'direito', algo que qualquer um pode - e deve - buscar (neste sentido, paradoxalmente descrito como um dever, não um direito). Neste cenário, se introduz a salvação a uma vida pouco 'apaixonada' pelo trabalho: o porquê, que certamente será um acrônimo com base no WHY inglês.

Ainda na introdução, Sinek (palestrante com a 'terceira maior audiência nos TED Talks', em 2017) anuncia não apenas que o livro foi, de fato, escrito por seus colaboradores; também explica como plenitude, felicidade e propósito se conectam.

Cada um de nós tem um 'porquê' (WHY), um propósito muito enraizado, causa ou crença, que atua como fonte da nossa paixão e inspiração. Você pode ainda não saber qual é o seu, ou como expressá-lo em palavras. Mas lhe garantimos, você tem um. Se gostaria de entender seu 'porquê' e prefere não esperar (...), este livro pode ajudar.

Plenitude não é outro termo para felicidade. Todo tipo de coisa nos faz feliz no trabalho: alcançar uma meta, receber uma promoção, emplacar um novo cliente, completar um projeto - a lista é longa. Mas felicidade é temporária; a sensação não dura. Ninguém anda por aí energizado pela memória de uma meta alcançada há um ano. Essa intensidade passa com o tempo.

Plenitude é mais profundo. Plenitude dura. A diferença entre felicidade e plenitude é a diferença entre gostar de algo e amar algo.

(...) Plenitude vem quando nosso trabalho está conectado 
diretamente com nosso porquê. (...) Felicidade vem daquilo que fazemos. Plenitude vem do por que fazemos.

(Sinek et al., 2017. P. 6-7, trad. livre)

Simples assim: para definir o seu slogan 'Porquê', basta utilizar o formato "Para , e com isso ", de maneira a) simples e clara; b) pronta para a ação; c) com foco no efeito que terá em outros e d) expressa em uma linguagem afirmativa que ressoe com você. (Sinek et al., 2017. P. 35, trad. livre) Trata-se, efetivamente, de um exemplo extremo; nestas sequências de técnicas para encontrar o propósito, os autores ainda flertam com conceitos como 'motivação', 'sentido', e outras simplificações cruas e reducionistas para ajudar indivíduos, equipes e empresas a nobilizar sua proposta de ganho de capital via trabalho. Trata-se de mais um exemplo de criação de mensagens que condensam esta suposta transcendência e repatriam afetos antes reservados a uma relação mais conflituosa, complexa e reflexiva a uma realidade corporativa de apreensão plena da subjetividade. Como afirma Linhart (2009, P. 19-20, 22-24, 129-130), o objetivo é capturar toda a subjetividade dos trabalhadores e mobilizar cada um desses recursos em função da criação de valor para o acionista. Existe a autonomia, mas essa autonomia serve somente para "fazer face a todos os objetivos contraditórios" impostos pela liderança. (Linhart, 2009. P. 130 - 131).

Para além desse discurso da autoajuda contemporânea, ainda há muitos pesquisadores que basearam seus trabalhos em busca de uma lógica sobre o que motiva os indivíduos contemporâneos. Uma dessas linhas de pesquisa tenta apreender de que forma são estabelecidos os 'contratos psicológicos' no trabalho, uma forma de prever e minimizar conflitos por meio de uma maior afinidade entre expectativas e a realidade experimentada no trabalho.

Na edição 13 da revista Jacobin, publicada em 2014, a Doutora em História da Arte Miya Tokumitsu publicou um artigo intitulado "In the Name of Love" (Em nome do Amor), chamando atenção para um dos aspectos mais nocivos do discurso capitalista pós-moderno. Em seu subtítulo, põe o dedo diretamente na ferida: as "Elites abraçam o mantra "faça o que você ama", sem refletir o quanto isso desvaloriza o trabalho e fere trabalhadores". Seu artigo - amplamente 
comentado, citado, compartilhado - traz luz à essa ascensão da ilusão de que seria possível fazer apenas o que se quer e ser bem remunerado por isso, e especialmente aos riscos que essa ideologia traz à maioria das pessoas. Inclusive, foi esse artigo que impulsionou a publicação de seu livro subsequente "Do What you Love and other Lies about Happiness and Success". (Faça o que Ama e outras mentiras sobre felicidade e sucesso, 2015).

Como mencionado anteriormente, não deveria haver nada ruim em se fazer o que se ama; no entanto, será que todas as profissões são 'amáveis'? E mais ainda: quanto dessa nova tendência não serve justamente para devolver ao empregado a responsabilidade por seu próprio sofrimento? ('algo como se você não está feliz nas condições ruins que lhe proporciono é culpa sua, pois não foi atrás do que ama').

Há muitos exemplos de publicações que glorificam o mantra "Faça o que você ama”. O artigo da publicação online 'Brainpicking' (Popova, M. 2014) é um deles; a autora Maria Popova lista não uma, mas sete fontes para alimentar esse ato de orientar a escolha profissional pelo 'amor'. O primeiro deles é do autor Paul Graham, que alerta para os perigos de uma escolha profissional guiada pelo prestígio; Alan de Botton, creditado como 'filósofo e criador do gênero literário da autoajuda,56 alerta contra o risco de absorvermos a definição de sucesso de outras pessoas ao invés de lutarmos por nossas próprias ideias; Lewis Hyde, que defende a reflexão sobre 'trabalho' versus 'labor' (mais orientado pela leitura do tema de Domenico de Mais do que à de Hannah Arendt, já explorada anteriormente). Enfim, esses e outros exemplos gravitam em torno do tema e defendem que um trabalhador descontente deveria largar seu "emprego" e buscar uma forma de fazer o que ama.

Tokumitsu traz ao tom justamente esse ponto: "o "faça o que ama" (FQA, ou DWYL em inglês) na maioria das vezes não conduz à salvação, mas à

\footnotetext{
${ }^{56}$ Essa informação não converge com outras fontes que nos parecem mais rigorosas. Eva lllouz, por exemplo, lista Samuel Smiles, um autor de 1859 que ganhou popularidade pelo seu livro chamado Self-Help. Seu livro trazia uma série de biografias de homens que saíram da obscuridade para alcançar fama e fortuna, e reforçava a ideia Vitoriana de que a responsabilidade individual, otimismo e voluntarismo moral conduziam ao sucesso, uma base na fé no progresso. O 'espírito de auto ajuda na ação energética de indivíduos', o poder de alcançar objetivos por seus próprios esforços (lllouz, E. 2007, P. 40).
} 
desvalorização do trabalho em si, e mais importante ainda, à desumanização de muitos trabalhadores. "De acordo com essa forma de pensar, trabalhar não é algo feito em troca de uma compensação, mas um ato de amor. Se o ganho não vier, supostamente é porque a paixão e determinação do trabalhador foram insuficientes. Sua conquista real é fazer com que os trabalhadores acreditem que seu esforço serve a si (self), e não ao mercado". (Tokumitsu, 2014)

Como um grande exemplo dessa ideologia, Tokumitsu traz o mito em torno de Steve Jobs e a criação da Apple, como se a empresa tivesse sido criada como um gesto e amor, e não pelos milhares de funcionários que se sacrificaram para tal. Ela cita seu famoso discurso em Stanford, de 2005, no qual disse a uma multidão de formandos que deveriam "achar e fazer o que amam. (...) A única forma de fazer um grande trabalho é amar o que se faz". Enfim, o indivíduo é lançado a ser o único responsável por seu sucesso, sem pensar no quanto isso depende de fatores como uma compensação justa ou condições de vida favoráveis.

O texto prossegue em um tema que já foi citado - o isolamento do sujeito em uma sociedade que valoriza o individualismo extremo, especialmente no sentido do quanto isso favorece a desagregação dos sujeitos e estímulo à competitividade interna. Além desse aspecto mais "pessoal" do isolamento, cria categorias distintas de trabalho: de um lado, o trabalho nobre, admirável; de outro, aquele feito pelos que não acharam o que amam, como lavar fraldas, cuidar de doentes, etc.

Uma consequência deste isolamento é a divisão que o FQA cria entre trabalhadores, especialmente ao longo de linhas de classe. $O$ trabalho torna-se dividido entre duas classes opostas: o amável (criativo, intelectual, socialmente prestigioso) e o não amável (repetitivo, não intelectual, indistinto). As pessoas do trabalho amável são amplamente privilegiadas em termos de fortuna, status social, educação, vieses raciais sociais e de alcance político, e representam uma minoria da força de trabalho.

(Tokumitsu, 2014. Trad livre) 
Ou seja, além de haver a dificuldade de estabelecer laços de confiança e apoio mútuo entre os trabalhadores, o FQA promove uma divisão no próprio conceito de trabalho. No entanto, será que todas as profissões seriam amáveis? Qualquer um teria condições sociais e econômicas de efetivamente fazer apenas o que ama?

Faça o que você ama' encobre o fato de que ser capaz de escolher uma carreira primeiramente por uma recompensa pessoal é um privilégio, sinal de classe socioeconômica". (..) Se acreditamos que trabalhar como um empreendedor no Vale do Silício, publicitário de museu ou um dos iniciados de um think-tank é essencial para que sejamos verdadeiros consigo mesmos, o que acreditamos sobre a vida interior e esperanças dos que limpam quartos de hotel e repõem prateleiras em supermercados? A resposta é: nada.

De acordo com a Secretaria de Estatísticas de Trabalho Norte Americana (U.S. Bureau of Labor Statistics), as duas profissões que crescerão mais rápido quando projetadas até 2020 são "ajudante de cuidados pessoais" e "ajudante de cuidados domiciliares (home care), com salários médios em 2010 de U\$ 19.640 ao ano e U\$ 20.560 ao ano, respectivamente.

(Tokumitsu, M. 2014. Trad livre)

Nem todos têm a possibilidade de escolher o que querem, e o lado perverso do FQA é justamente de atribuir ao trabalhador a responsabilidade exclusiva por seu próprio mal estar. Evidentemente que na sociedade capitalista pós-moderna há maior possibilidade de escolha, mas a mesma sociedade requer que pessoas dediquem tempo e esforço a tarefas que não são agradáveis, fáceis de conviver, ou bem remuneradas por isso. Para ilustrar em detalhe, Tokumitsu traz um exemplo que considera emblemático: o mundo profissional universitário.

Não há um segmento no qual o mantra FQA têm sido mais devastador do que no mundo acadêmico. O estudante de doutorado médio em meados de 2000 deixou de lado o 'dinheiro fácil de Finanças ou Direito' (hoje menos fácil!) para viver com um estipêndio mísero para seguir sua paixão por Mitologia Nórdica ou história da música Afro-Cubana.

A recompensa por responder a esse chamado dos céus é um mercado acadêmico no qual cerca de $41 \%$ dos professores acadêmicos norte americanos são professores adjuntos - instrutores contratados que normalmente recebem baixos salários, sem benefícios, sem uma sala própria, sem segurança profissional e sem carreiras de longo prazo nas escolas nas quais trabalham.

Muitos fatores mantêm Doutores nesse ciclo de oferecer tal mão de obra altamente qualificada por remuneração tão baixa, incluindo a 
obrigatoriedade de seguir nesse caminho [para se tornar um Doutor] e o investimento financeiro já realizado até então para se tornar um Doutor. No entanto, um dos mais fortes é a quão invasiva a doutrina FQA está inserida na academia. Poucas profissões fundem a identidade pessoal de seus trabalhadores tão intimamente com a produção do trabalho. Como a pesquisa acadêmica deveria ser realizada por puro amor, as condições reais de compensação por esse trabalho tornaram-se algo a ser elaborado a posteriori, e talvez jamais seja pensado a fundo.

Em "Trabalho Acadêmico, a Estética da Administração e Promessa de Trabalho Autônomo" ("Academic Labor, the Aesthetics of Management, and the Promise of Autonomous Work"), Sarah Brouillette escreve sobre o trabalho acadêmico: "Nossa fé de que nosso trabalho oferece recompensas não materiais e de que seria mais íntegro com a nossa identidade do que um trabalho 'comum' nos torna os empregados ideais quando a meta do empregador é extrair o valor máximo de nosso trabalho a um custo mínimo.

(Tokumitsu, 2014. Trad livre)

Trata-se de um exemplo detalhado, repetido em muitos países, que ressalta o risco do estabelecimento do FQA como uma ideologia ideal para a extração do máximo valor ao menor custo. O mundo acadêmico não é de forma alguma o único, evidentemente: a autora cita também grifes de alta costura ${ }^{57}$ que, assim como escolas de gastronomia e outros segmentos glamorosos, exploram a força da marca para atrair jovens talentos pelo puro prazer ou status de trabalhar nestes estabelecimentos. Trata-se de uma troca que capitaliza no valor que essas pessoas terão como empregabilidade futura. Contudo, será que é uma troca justa?

Ninguém disse que o trabalho prazeroso deveria ser menos aproveitado. No entanto, um trabalho que seja emocionalmente satisfatório também é trabalho, e reconhecer isso não o diminui em nada. A recusa de reconhecer isso, ao contrario, abre a porta para a exploração e prejuízo de todos os trabalhadores.

(...) Nada faz a exploração ser mais aceita do que convencer os trabalhadores de que estão fazendo aquilo que amam. (...) O FQA (...) é, de fato, a ferramenta ideológica perfeita para o capitalismo. Se enxergássemos todo nosso trabalho como trabalho, poderíamos

\footnotetext{
${ }^{57}$ Um dos exemplos recentes desta ideia aconteceu em 2018, em São Paulo. Um estilista bastante renomado teve seu desfile interrompido pela Polícia, que seguia uma denúncia do Sindicado de Artistas que regulamenta a profissão de Modelo Profissional. A denúncia se baseava no fato de que o estilista teria empregado modelos não profissionais que residiam fora do município de São Paulo, o que o permitiu legalmente não pagar salário algum a esses indivíduos. Quando questionado, sua assessorial simplesmente respondeu que a estratégia não teria sido baseada em um meio de evasão fiscal ou economia dos salários, mas 'dar a pessoas bonitas de outras localidades a oportunidade de se promover e ganhar mais visibilidade'.
} 
estabelecer limites apropriados para ele, exigir compensação justa e horários humanos que permitissem tempo para a família e o lazer. E se fizéssemos isso, mais de nós seriam capazes de efetivamente fazer o que amam.

(Tokumitsu, 2014. Trad. livre)

O pressuposto de que a maioria dos indivíduos poderia se manter ao fazer exclusivamente o que ama como trabalho remunerado pode ser bastante perigoso - especialmente se for esperado também que isso traria felicidade e propósito. Além desse raciocínio implicar na diferença entre atividades 'amáveis' e aquelas difíceis de amar, essa diferença ganha mais corpo quando a escolha por uma carreira pouco apreciável não só representaria insatisfação, mas também covardia: no mundo em que tantos 'fazem o que amam e são felizes', os que não tem coragem (ou recursos) para buscar esse caminho seriam fracassados. Além disso, esse pressuposto do 'Faça o que Ama' mascara o fato que a maioria das atividades remuneradas envolvem maior ou menor nível de frustração e esforço, e que há muitos trabalhos efetivamente difíceis de amar. Em lugar de melhorar as condições de trabalho ou criar esforços para eliminar atividades desagradáveis, a lógica do FQA repatria toda a responsabilidade pelo sofrimento ao indivíduo. ${ }^{58}$

Além de mostrar o caráter manipulador desta união entre amor e trabalho, estas reflexões nos apontam para uma outra direção perigosa para os indivíduos. Assim como em outros exemplos de uso do marketing para aumentar a atratividade de algo que, em si, não seria atribuído tamanho valor, a imagem inflada e exagerada do cotidiano de trabalho pode levar ainda a uma outra frustração muito comum no discurso dos trabalhadores: a discrepância entre expectativas e realidade. Neste ponto, o discurso analítico é unívoco; o sofrimento do adulto usualmente está associado à distância inevitável entre o real compartilhado e frustrante e o mundo interno idealizado, muitas vezes alucinado

\footnotetext{
${ }^{58}$ Um artigo publicado em 2014 por Brett D. Lashua, da Leeds Metropolitan Universityy também discute os trabalhos da Dra. Tokumitsu. Esse texto, provocativamente intitulado "DWYL? YOLO..." reforça suas ideias dos riscos em assumir que a escolha profissional poderia ser baseada exclusivamente em prazer ou satisfação pessoal (DWYL é um acrônimo para Faça o que Ama, enquanto YOLO é uma gíria usada por jovens norte americanos para "You Only Live Once", 'só se vive uma vez').
} 
nas expectativas. Mesmo assim, como profissionais de saúde mental, é essencial colocar em perspectiva esses elementos e perceber o potencial destrutivo que essa ideologia pode ter na subjetividade. Uma reflexão possível, para fechar esse ponto, seria regressar a Freud e seu "Inibição, Sintoma e Angústia", de 1926. Nesse texto, o psicanalista alerta para os riscos de angústia que podem estar associados à expectativa (Freud, 1926 / 2014).

\begin{abstract}
A angústia tem uma inconfundível relação com a expectativa: é angústia diante de algo. Nela há uma característica de indeterminação e ausência de objeto; a linguagem correta chega a mudar-lhe o nome, quando ela encontra um objeto, e o substitui por temor [Furcht]. (P. 114)

Há casos em que características de angústia realista e da angústia neurótica aparecem mescladas. [a primeira, angústia frente a um perigo exterior; a segunda frente um perigo desconhecido do Eu, interior] O perigo é conhecido e real, mas a angústia diante dele é excessiva, maior do que poderia ser pelo nosso julgamento. (Freud, 1926 / 2014, P. 115)

Qual é o núcleo, o significado da situação de perigo? É claramente a avaliação de nossa força em comparação com sua grandeza, a admissão de nosso desamparo em relação a ela; do desamparo material, no caso do perigo real; do desamparo psíquico no caso do perigo instintual. (Freud, 1926 / 2014. P. 115)

A angústia é, de um lado, expectativa do trauma [já vivido] e, de outro lado, repetição atenuada do mesmo. (...) O Eu, que viveu passivamente o trauma, repete ativamente uma reprodução atenuada do mesmo, na esperança de poder ele mesmo dirigir seu curso.
\end{abstract}

(Freud, 1926 / 2014 P. 116)

Como vimos no texto freudiano, a expectativa é um motor para a angústia nos neuróticos. Ainda assim, não faltam discursos no mercado que aliem a realidade do trabalho a uma ilusão de gerador de propósito; para citar mais um exemplo contemporâneo, no jornal A Folha de São Paulo de 18 de Outubro de 2018 foi publicado um artigo chamado "Todo negócio tem uma causa, uma motivação". Nele, consta a entrevista com Thomas Eckshmidt, co-fundador da instituição 'Capitalismo Consciente' no Brasil e dedicado a "divulgar um modo de administrar empresas que leva em consideração o benefício de todos os elos da cadeia: do fundador ao fornecedor, do cliente ao funcionário". Em seu recente livro, "Capitalismo Consciente - Guia Prático", esse autor propõe uma "espécie 
de cartilha para que os empresários repensem sua forma de atuação e encontrem um propósito para seu negócio".

Mais uma vez, trata-se de uma proposta arriscada, que fomenta essa expectativa - sem dúvida, geradora de angústia para muitos - de que os negócios sejam orientados por propósitos nobres. Esse autor, por exemplo, defende na mesma entrevista que as empresas devem refletir não apenas sobre o ganho financeiro, mas também em valores mais elevados de cunhos "sociais, ambientais, econômicos e culturais". Como vimos anteriormente nos trabalhos de Lipovetsky, existe uma faceta de avanço em trazer estas preocupações para os capitalistas contemporâneos; no entanto, será possível conciliar algo tão amplo como valores sociais e culturais à busca pelo lucro e extração máxima de 'valor' do trabalho de seres humanos? Mais ainda, que tipo de expectativas são criadas nos trabalhadores ao se divulgar preocupações com o social, o meio ambiente e a cultura, e quais os efeitos caso estas expectativas sejam frustradas?

Embora estas considerações sejam interessantes para pensar a questão - ou a problemática - da associação entre o propósito no campo do trabalho, esta discussão seria incompleta sem mencionar o trabalho de Dany-Robert Dufour. Em seu livro "A Arte de Encolher Cabeças" (The Art of Shrinking Heads, originalmente lançado em 2003), o filósofo francês trata de inúmeros temas que poderiam nos encaminhar a uma visão bastante crítica da associação entre trabalho e propósito. Um primeiro ponto, por exemplo, seria sua leitura sobre uma das facetas da modernidade: "A Modernidade é, enfim, aquilo que ataca tudo". (Dufour, 2008. P. 35. Trad. Livre.) Em sua visão, a pulsão do sujeito moderno por desautorizar todas as instituições anteriores - a família tradicional, a igreja, a própria transcendência - inadvertidamente o levou, esse homem moderno, a se ver perdido no mundo. Em busca de uma possibilidade inédita de fruição, liberdade e realização de si por si mesmo, o indivíduo moderno viu-se simultaneamente emancipado dos roteiros estabelecidos pelo Outro e mortalmente solitário. 
Na visão deste autor, a contemporaneidade neo-liberal (o que se aproxima do que outros nomearam como hipermodernidade) exagerou essas tendências e conduziu a um sujeito em ruptura com referências externas, apartado do "sujeito kantiano" crítico e racional e do "sujeito freudiano" neurótico, o indivíduo fixado em seus próprios desejos, obsessões e repetições. Livre de crítica, da razão, das obsessões idiossincráticas ${ }^{59}$ e da compulsão por repetir, esse novo sujeito seria, enfim, um receptor universal para todas as commodities possíveis, um ávido consumidor e permanentemente consumido pela necessidade de ter mais. E, exatamente por essa perspectiva e pela eliminação de todas as figuras de controle, por ter rompido com o Outro que o submete, mas sem o qual não há subjetivação possível, esse sujeito encontra-se eminentemente divorciado da possibilidade de criar ou aderir a um propósito. O ponto central para Dufour é a ruptura com os "garantidores sociais": "Sem esse Outro, esse garantidor metasocial, é difícil para o sujeito ser um self. Ela [ou ele] não sabe para onde correr, e todo o estar-junto está em perigo por si só, uma vez que a referência comum ao mesmo Outro é a única coisa que permite que indivíduos diferentes pertençam à mesma comunidade”. (Dufour, 2008. P. 25-26. Trad. Livre.)

Assim, nos é possível construir uma hipótese que explicaria a 'commodificação' do propósito, e uma explicação pela qual esse conceito retorna às prateleiras da auto-ajuda como algo a ser vendido e explorado; para esse sujeito neo-liberal ou hipermoderno, esse vazio de propósito é algo a ser preenchido não pelo transcendente ou pela dúvida que conduz à reflexão sobre si e o outro. Trata-se de algo que se sacia em infindáveis e efêmeros sentidos produzidos como mercadorias, fadados a serem consumidos e eliminados, perecíveis, fadados à obsolescência programada das commodities. Ao resistir à condição de submissão que implica na condição de sujeito - e, aqui, fazemos novamente

\footnotetext{
${ }^{59}$ Talvez um dos últimos exemplos nas décadas de 1980 e 1990 dessa 'obsessão idiossincrática' seja o caricato Steve Jobs; mesmo ultra rico, usava a mesma combinação de camiseta de mangas longas, preta de gola alta e jeans. Essa obsessão teria nascido após uma visita de Jobs à Sony, no Japão, na qual ficou fascinado ao ver todos os funcionários usando exatamente a mesma roupa (e imaginar que isso os faria perceber uns aos outros de maneira mais uniforme). Ao pedir ao estilista japonês Issei Miyake (que desenhou os uniformes da Sony) para fazer os uniformes da Apple, também pediu um conjunto de camisetas pretas, gola alta. Recebeu centenas, 'o suficiente para usar pelo resto da vida'.
} 
referência ao desejo de autonomia - "o sujeito é tanto aquele que é submetido como aquele que resiste à submissão. Em outras palavras, o sujeito é o sujeito do Outro e aquele que resiste ao Outro". (Dufour, 2008. P. 21. Trad. Livre.) Tratase efetivamente de um efeito colateral da "crescente autonomia do indivíduo que permite novos prazeres, mas também causa novas formas de sofrimento". (Dufour, 2008. P. 15. Trad. Livre.) Dito de outra maneira: "um sujeito que está aberto a todos os tipos de identidades flutuantes e que, desta forma, está pronto para ser conectado a toda e qualquer commodity. O cerne do sujeito [le vif $d u$ sujet] está gradualmente sendo substituído por um vazio subjetivo [le vide du sujet], aberto aos quatro ventos". (Dufour, 2008. P. 12. Trad. Livre.) ${ }^{60}$

Possivelmente, a abordagem teórica que melhor abarca a apropriação do conceito de propósito pelas organizações contemporâneas seja também da obra de Dufour; o autor afirma que "enquanto as patologias modernas frequentemente revolviam em torno de uma paixão por ser um outro, as patologias pós-modernas agora revolvem em torno da necessidade de ser auto fundacional" (Dufour, 2008. P. 80. Trad. Livre.). A tese de Dufour é que o sujeito contemporâneo, após romper com as referências externas e 'forcluir os Nome-do-Pai', negar e extirpar a castração e a possibilidade de recorrer aos 'garantidores sociais', se vê condenado a um dilema paradoxal. Ao mesmo tempo em que se vê obrigado ao imperativo 'anti-Kantiano' 'seja você mesmo', esse 'você mesmo' tem que ser definido a priori. Antes mesmo de experimentar as possibilidades de subjetivação na relação com o Outro, explorar a multiplicidade e os conflitos inevitáveis do laço social, esses sujeitos se obrigam a determinar esse "você mesmo" a partir de supostas 'oportunidades' infinitas, alucinadas e capturadas do ideário social. Mais que isso: além de obrigar a uma escolha que não se dá entre alternativas delineadas em um contexto pessoal, a escolha entre toda e qualquer possibilidade de ser ainda traz o peso de atuar como catalisador de uma

\footnotetext{
${ }^{60}$ Nosso acesso a esse texto foi à edição norte-americana / inglesa; ainda assim, o tradutor assinalou as expressões originais mostradas entre colchetes. Trata-se de um jogo brilhante de palavras: le vif du sujet poderia ser compreendido como "o que move o sujeito, seu cerne" e ainda assim manter uma ambiguidade com o caráter de matéria, tópico do termo "sujet". Nesta segunda leitura, a frase poderia soar algo como 'O ponto central do que quero dizer é que tratamos do vazio do sujeito aberto aos quatro ventos', ainda assim mantendo essa relação poética entre vif du sujet / vide du sujet, praticamente homofônicos.
} 
existência plena ${ }^{61}$. O sujeito pós-moderno, desta forma, teria rompido com o simbólico; rejeitando os garantidores e em especial a castração. No entanto, justamente por recusá-lo, por extirpar de si as mazelas da castração, se vê lançado em um vazio de identidade e, consequentemente, a possibilidade de constituir um propósito. Suas possibilidades de constituição de si veem-se limitadas e fadadas à superficialidade, uma vez que a definição de sua identidade e propósito é exigida antes de deixar-se tomar contato com os outros e o mundo do trabalho.

Nesta perspectiva, esse falso propósito não só seria algo necessário para a estabilização de si, mas outra commodity a ser absorvida, consumida e, por isso, perecível e transitória. O propósito seria, assim, convertido em outro 'job'; algo ao mesmo tempo transacional e superficial, e essencial para funcionar nesta nova ordem das coisas. Como o trabalho, torna-se um dos escolhos com os quais o indivíduo pós moderno se orienta; e assim como o 'job', o toco que se carrega pelo caminho da 'carreira', destinado a se tornar um fardo e descartado pelo caminho. Não se trata apenas de uma mudança acidental; há uma intenção em parear esse indivíduo hipermoderno, mergulhado em uma efervescência do excesso, com movimentos claros de construção de uma garantia para a maisvalia neoliberal. A criação de propósito e ideais que alinham o sujeito e a organização são parte integrante do zeitgeist contemporâneo.

Seja como for, o mercado está sendo inundado, naquele espaço vazio deixado pelo colapso contemporâneo dos ideais do Eu e o aspecto simbólico do supereu. Os propagandistas já perceberam que podem explorar o tropeço do supereu e tentar criar marcas a partir de nossos novos marcadores simbólicos. O mercado (e, especialmente, o mercado em imagens) tornou-se um dos maiores fornecedores de novos e voláteis ideais do Eu, constantemente reformulados.

\footnotetext{
${ }^{61}$ Para esclarecer esta frase, vale à pena compartilhar uma vinheta clínica. Um jovem bastante bem-sucedido em comparação à maioria dos brasileiros de sua faixa etária chega ao consultório com alto nível de ansiedade e frustração. Cada vez que fala com outra pessoa sobre trabalho, é invadido por pensamentos que aquele trabalho seria melhor que o seu; seria mais feliz se fizesse aquilo. Tinha medo de continuar no emprego atual - no qual estava há seis meses - e ver-se 'fracassado' em alguns anos, mesmo sem ver-se capaz de definir em que esse fracasso consistiria. Trabalhos que pagavam menos the pareciam mais nobres e conectados com um propósito social, enquanto os mais bem pagos o levariam à riqueza. Mesmo percebendo que a felicidade estaria ou no propósito ou no enriquecer, via-se incapaz de escolher por essa pluralidade de oportunidades.
} 
Concluindo, não é à toa que o conceito de propósito foi importado dos campos da religião ou da moral. A hipótese de Dufour nos leva de volta a esse elemento central da contemporaneidade, o indivíduo hipermoderno, ou esse sujeito que abandona a crítica e a culpa em troca de um entorpecimento pelo excesso, incapaz de suportar a castração e angustiado frente à abundância de escolhas. Com uma infinidade de commodities disponíveis e um desejo que não encontra um sujeito capaz de satisfação, a angústia e alienação são o caminho possível. Trata-se de uma dinâmica tóxica, mas uma que deve ser parte do desafio intelectual desta época. A melhor conclusão possível seria voltar ao próprio Dufour.

Por outro lado, eu devo admitir que a destruição trágica deste homem nos oferece uma oportunidade inesperada [o sujeito crítico kantiano e suas antigas neuroses freudianas]. De fato, nos encontramos em uma situação intelectual excepcional. Tudo está no lusco-fusco. Temos que reconstruir tudo, começando por uma nova inteligência crítica e um novo entendimento do inconsciente. Estamos muito próximos da posição em que se encontrava Descartes em Amsterdam, 1631, alguns anos antes de escrever Le Discours de la méthode: 'Nesta grande cidade na qual vivo, sem qualquer um fora eu envolvido no comércio [trade], todos estão de tal forma concentrados em seus lucros que poderia passar toda minha vida sem ser visto por qualquer um'. Descartes, sendo um homem que conseguia manter a calma mesmo nas situações mais desesperadoras, é o personagem teórico que precisamos aqui; enquanto o resto mundo se vê envolvido no comércio [ou trocas], ele goza da 'liberdade completa'. É quando suas dúvidas estão na maior intensidade que ele redescobre, graças a essas mesmas dúvidas, o mais rigoroso dos exercícios filosóficos; o que, enfim, serviu para achar uma nova certeza.

(Dufour, 2008. P. 168-169. Trad. Livre.)

Que encontremos as dúvidas, e com elas, novas certezas (ou novas dúvidas). E antes de pensar neste 'novo inconsciente' e esta 'nova inteligência crítica', é importante aprofundar um pouco no conceito do indivíduo hipermoderno. 
O tema da hipermodernidade - mais rigorosamente, do indivíduo hipermoderno - já foi bastante explorado em nossa tese; o objetivo de complementar o já dito diz respeito a um tema ainda pouco explorado. Os autores que citamos - em especial Dufour, Aubert e Castel - apontam como um dos elementos centrais da contemporaneidade uma dualidade na organização social. Como afirmamos anteriormente, não seria possível transpor essa realidade teórica francesa para o contexto geral brasileiro. Nossos desafios socioeconômicos são de tamanha complexidade que as desigualdades se espalham em múltiplas facetas, com áreas menos desenvolvidas que funcionam como décadas atrás na Europa. Ainda assim, trata-se de uma referência essencial para compreender as demandas de mal estar no trabalho na contemporaneidade, especialmente nos grandes centros metropolitanos.

Inicialmente, é importante diferenciar o tema do 'indivíduo hipermoderno' ou sua personalidade de uma discussão sobre a 'época' ou 'sociedade' hipermoderna. Aubert ressalta que como estamos no curso desta transformação, ainda é impossível entender o período como uma estrutura histórica estabelecida. Ainda assim, os consultórios e escritórios de coaches recebem mais e mais pessoas que buscam ajuda para o que pode ser definido como patologias da hipermodernidade, estas sim, já bastante estudadas, exploradas, revistas.

Desta forma, nesta última sessão de nosso trabalho será dedicada a uma recapitulação do conceito no trabalho dos dois autores que nos parecem mais prolíficos sobre o tema - Nicole Aubert e Robert Castel - assim como aprofundar alguns temas que foram tratados de modo mais passageiro. Embora tenhamos outros autores notáveis que exploraram o tema, trabalhos como o de Lipovetsky e Baumann já foram citados em seus aspectos mais imediatamente relacionados à esta tese.

Como mencionado anteriormente, há divergências sobre a autoria do termo 'hipermoderno', embora os conceitos convergem em termos de seu significado. 
Segundo Nicole Aubert, sua primeira produção sobre o tema foi em setembro de 2003; ao coordenar um colóquio na Escola Superior de Comércio de Paris (ESCP-EAP) consagrado ao 'Indivíduo Hipermoderno'. Um ano mais tarde, a autora organizou um livro seminal intitulado "L' Individu Hypermoderne" ('O Indivíduo Hipermoderno). Nesta obra, convidou profissionais de disciplinas diversas para discutir as implicações das mudanças na sociedade que poderiam explicar as transformações pós 1970. Embora haja dificuldades epistemológicas de analisar um fenômeno em andamento - ou um período histórico ainda não consolidado - na visão dos autores existem elementos comuns que podem ser observados como uma característica de transformação. A necessidade de prazer sensorial intenso $\mathrm{O}^{62}$, um aumento das tendências individualistas, a dificuldade de elaborar sentimentos e outros traços que marcariam um novo padrão, que poderia ser lido como um exagero daquilo atribuído a características da Modernidade.

Além do que já mencionamos anteriormente, Aubert apresentou anos depois um esquema que sumariza sua visão do indivíduo hipermoderno. Em de Fevereiro de 2011, apresentou em um Seminário da AFAPP (Associação Francesa de Acompanhamento Profissional) um texto intitulado "A Sociedade Hipermoderna, o Indivíduo Hipermoderno: Rupturas e contradições". Nesta fala, a autora determina quatro elementos centrais no que define como o indivíduo hipermoderno:

Primeiro elemento: o surgimento de uma nova relação com o tempo marcada por uma aceleração contínua;

Segundo elemento: o surgimento de uma nova relação com os outros marcada pelo efêmero;

Terceiro elemento: o surgimento de uma nova relação consigo, marcada por ultrapassar limites, pela intensidade, pelo excesso de si;

\footnotetext{
${ }^{62}$ Neste caso, sensorial seria uma forma de separar necessidades extremamente imediatas de prazer de outras que poderiam ser vistas como mais 'desenvolvidas' em termos de organização psíquica, ou ao menos mais mediadas por limites estabelecidos por um senso de compostura e adequação social. Indivíduos mais bem organizados em termos de constituição psíquica teriam a capacidade de encontrar satisfação em relacionamentos significativos, enquanto a busca de prazer puramente 'sensorial'. Por sensorial, usualmente indicam ciclos muito menores de satisfação, frustração e abandono, e um grau enorme de foco em si, e não em outros indivíduos ou organizações.
} 
Quarto elemento: a visibilidade, como a preocupação por se fazer visível tomar o lugar da interioridade, o espaço interior de si, como se algo se deslocasse ${ }^{63}$ para o exterior, uma 'mostração' aos outros daquilo que revelaria uma dimensão mais interior de si...

(Aubert, 2011. P. 3. Trad. livre)

Este sumário de Nicole Aubert nos parece o mais simples para determinar os elementos centrais do que consideramos as características do indivíduo hipermoderno. Mais além, a autora baseia sua análise em um apanhado de outras pesquisas e as explicita para mostrar um veio comum a esses trabalhos e conectá-lo a temas como a mudança das organizações familiares tradicionais, o uso excessivo da internet e os próprios efeitos da globalização, que depois seriam mais amplamente explorados como efeitos do Neo Liberalismo da contemporaneidade.

\begin{abstract}
Um grande número de trabalhos recentes - consagrados notadamente à família, às telas de computador, à Internet, ao trabalho, à psicologia contemporânea, e de modo geral aos efeitos do mercado e da globalização no indivíduo, são os centros da questão do eu, do indivíduo, da personalidade, do caráter contemporâneo: Lasch, Turckle, e ainda Castel e Enriquez, Sennett, Bauman, ou ainda Gauchet e Kauffman, se agarram à personalidade contemporânea , à maneira de ser de um indivíduo nas formas extremas do individualismo contemporâneo.
\end{abstract}

(Aubert, 2003. P. 32. Trad. livre)

Entretanto, até aqui foi abordada principalmente a faceta de excesso do indivíduo hipermoderno; autores como Lipovetsky atribuem a esse excesso uma origem nas transformações causadas pela indústria da moda. Dufour fala sobre uma estimulação intencional promovida pela indústria da propaganda e consumo no sentido de 'encolher cabeças': deixar os indivíduos menos críticos e mais flexíveis em suas preferências, um meio de garantir o 'encaixe com toda e qualquer commodity oferecida'. Essa faceta seria, sem dúvida, uma parte essencial da análise deste trabalho; não é incomum nos relatos clínicos da contemporaneidade perceber casos de pessoas que não conseguem encontrar satisfação em seu trabalho, transtornos compulsivos de todos os tipos, e mesmo

\footnotetext{
${ }^{63}$ No original, 'déportait' - deportar ou desviar.
} 
fenômenos como os workaholics (pessoas que não conseguem parar de trabalhar), o burnout (jornadas de trabalho tão extenuantes que levam o sujeito à exaustão e colapso) e mesmo o exemplo mais radical de todos, o karooshi (termo japonês que indica pessoas que morrem de tanto trabalhar, muitas vezes após dias a fio sem sair do escritório).

Já foram apresentadas inúmeras perspectivas que explicam essa passagem, mas uma boa referência adicional é a de Eugéne Enriquez. Em seu capítulo no próprio livro de Nicole Aubert, o autor sublinha os efeitos psicológicos de desilusão promovidas na transição para a hipermodernidade, algo que será essencial para compreender o 'duplo' ou o 'espelho' deste indivíduo marcado pelo excesso: o indivíduo definido pela 'falta'.

Robert Castel os chama dos "trabalhadores sem trabalho", evocando Hannah Arendt em sua "Condição Humana", que, a partir dos anos 1970, "ocupariam literalmente na sociedade um lugar de números excedentes, "inúteis no mundo"." (Castel, R. 1995. P. 623. Trad. livre) Trata-se de um dos efeitos que nomeia a precarização do trabalho, um dano colateral das flexibilizações dos contratos iniciados na França e 1975 (e vistos ao redor do mundo da mesma época em diante). Não à toa, seu livro sobre a Nova Questão Social encerra-se com uma conclusão sobre o Individualismo Negativo (Castel, R. 1995. P. 747. Trad. livre); se a sociedade [hipermoderna] se organizou para produzir indivíduos narcísicos, individualistas e conduzidos ao hiperconsumo e ao hipertrabalho, em seus bastidores também se produz uma cadeia de desfavorecidos, os indivíduos marcados por uma falta irreparável. Em seu texto, de meados da Década de 1990, ele fala especificamente sobre os favelados, imigrantes e desfavorecidos em geral - um contexto bastante familiar à realidade brasileira. Trata-se desta massa de indivíduos que não só não terão acesso às virtudes da contemporaneidade, mas que terão uma dificuldade crescente de acesso ao próprio mundo do trabalho.

O vagabundo efetivamente pagou um preço caro demais por essa ausência de lugar que o situa do outro lado do espelho das relações sociais. Além disso, o interesse principal de definir esta figura que tem uma falta, como vimos, é que representa uma posição limite em 
relação a uma gama de situações nas quais seu lugar está igualmente mal determinado em uma sociedade cadastrada. (...) Individualismo "negativo", uma vez que se declina em termos de falta - falta de consideração, falta de segurança, falta de recursos assegurados e laços estáveis.

A metamorfose que se opera ao fim do século XVIII pode ser interpretada a partir do encontro entre duas formas de individualização. O individualismo "positivo" se impõe na tentativa de recompro o conjunto de uma sociedade que tem uma base contratual. Pela imposição dessa matriz contratual, irá demandar, ou exigir, que os indivíduos sem dinheiro ajam como indivíduos autônomos.

(...) O pauperismo - uma representação-limite, como o vagabundo exemplifica essa des-socialização completa que reduz uma parte da população industrial a uma massa agregada de indivíduos sem qualidades.

(Castel,1995. P. 753-754. Trad. livre)

Trata-se efetivamente de uma perspectiva bastante diferente do indivíduo hipermoderno; além do sujeito do excesso, da busca por limites e da fruição desinibida, haveria seu duplo. Há um sistema que produz em busca do máximo de lucro e aceleração do consumo, mas os recursos são - e sempre foram limitados e finitos. Desta forma, é inevitável que esse mesmo sistema desregulado produza desigualdade, que se reflete nestas nossas formas de subjetivação. Em um contexto social no qual o valor e o preço se confundem, pessoas sem acessos e condições econômicas tornam-se não-cidadãos, e, neste ponto, podemos ver inúmeros paralelos com a realidade contemporânea brasileira.

Ainda assim, é importante entender melhor os mecanismos que conduziram a esta transformação. Assim como Robert Castel, outro autor que explica essa mudança de paradigma é Eugène Enriquez. De modo mais sucinto, o autor irá mostrar sua própria análise dos fatores que deram forma a essa nova 'Questão Social', em especial da transição da Modernidade para a Hipermodernidade. Claramente, sua análise parte da hipótese de que essa transição foi, entre outros fatores, motivada por um desencantamento pelas promessas tecnológicas e ideológicas modernas.

O "desencantamento com o mundo" (Weber) deixou muitos homens desorientados e prontos a aderir às novas fórmulas religiosas, que tinham um charme de novidade, tomando uma carga de angústia e funcionando como dispositivos que reasseguravam o narcisismo. As 
crenças não haviam desaparecido, elas se multiplicaram, e elas se enunciam com muito mais injunções que as religiões tradicionais. (...)

Foi então que novos sagrados apareceram: o dinheiro, tomando a forma de um fetichismo sagrado, adorado pela maioria e que governa a sorte de nações e indivíduos; o sexo, transformado em ídolo sob o qual todos devem se submeter; a segurança, exigência profunda de todo mundo que quer ser protegido de todos os riscos da vida (não somente ladrões e assassinos, mas a poluição, o calor intenso, etc.); a saúde, transformada em preocupação constante das populações desde a introdução de medicamentos 'milagrosos' (antibióticos, ansiolíticos, antidepressivos) e os sucessos da cirurgia (da microcirurgia à cirurgia estética). Todo mundo quer ter boa saúde, ou seja, jovem e belo se for possível.

O nascimento e a difusão destes novos sagrados, assim como sua ascensão no pensamento e nas condutas dos sujeitos contemporâneos, militaram a favor de um prolongamento entre o mundo da modernidade, tal qual era concebido no final dos anos 1970 e nosso mundo contemporâneo, ou mesmo de uma intersecção entre esses dois mundos. (Enriquez, In: Aubert, 2003. P. 43-44. Trad. livre)

A leitura de Enriquez é precisa, e, além disso, estabelece essa linha contínua que reforça a importância de não se ver a hipermodernidade como uma mudança de paradigma, mas de uma exacerbação dos mesmos. Nessa perspectiva, o sujeito hipermoderno seria uma entidade familiar, já preconizado em inúmeras mudanças - e, como afirma Enriquez, conquistas sociais - dos tempos anteriores.

[As características fundamentais a serem exploradas pela hipermodernidade seriam] a construção de um mundo em que o desejo individual, apoiado pela tecnociência e a racionalidade instrumental, a solidão e o narcisismo subsequente, aparecia predominantemente em relação aos vários coletivos profundamente interiorizados por cada um, que se apresentam de formas de leis quase naturais, e que guiam facilmente nossas atitudes e condutas.

(Enriquez,. In: Aubert, 2003. P. 43-44. Trad. livre)

Desta forma, surge uma nova faceta para o tema do indivíduo hipermoderno; nem mesmo esse caráter de 'novidade' pode ser atribuído a ele. Um olhar mais atento à filosofia já anunciava o emergir desses problemas sociais, amplamente acelerados pela expansão do capitalismo e sua ideologia dominante. Para citar um exemplo desse pensamento, vale retornar à análise de Olgária Matos e 
perceber o quanto desta semente da hipermodernidade já estava presente no pensamento de Walter Benjamin.

\begin{abstract}
Assim, ao capitalismo baseado no estoque - em que se produz e acumula a longo prazo - segue-se o capitalismo do descartável, em uma relação inédita do dinheiro com o tempo; o longo prazo, a durabilidade, são considerados "perda de dinheiro" e "perda de tempo", com a obsolescência contínua e programada de coisas e valores. No que diz respeito ao espaço público, a fusão da economia e política dissolve o ideário iluminista da experiência de uma esfera comum e acessível a todos, espaço de autonomia com respeito às determinações diretamente materiais de sobrevivência imediata.
\end{abstract}

(Matos, 2009. P. 9)

É perceptível a conexão não apenas com a 'Dialética do lluminismo' de Adorno e Horkheimer, mas também os inegáveis elementos que comporiam o sujeito hipermoderno. Trata-se de uma nova relação com o tempo, dinheiro, consumo e a própria imagem, como anteciparam Aubert e Enriquez, em especial no que diz respeito à duração: o tempo da modernidade/ hipermodernidade aproxima-se, cada vez mais, do instantâneo. E, afinal, isso traz efeitos nocivos e patológicos para a esfera do trabalho. Segundo comentário da autora sobre o trabalho operário, este se transforma mais e mais em:

Trabalho diabólico, nos infernos da terra, ele é também repetitivo e sempre igual, automatizado e objetivado com respeito ao trabalhador de tal modo que, em suas relações com a máquina, os operários aprendem a ajustar e coordenar uniformemente seus próprios movimentos aos do autômato (Benjamin, 2000b, p. 103-49). Valendose das análises de Marx em O Capital, Benjamin interpreta o trabalho repetitivo do trabalhador no interior da grande indústria como perda da experiência e do saber fazer, perda de seu sentido e destinação. Diversamente do trabalho artesanal, o trabalho especializado moderno não é aperfeiçoamento progressivo, mas um alheamento de si nos mecanismos de estímulo e resposta, sem continuidade e sedimentação do saber e do fazer, isto é, sem experiência. Para Benjamin, a modernidade é o inferno, é repetição desesperadora de penas eternas e sempre novas, do aprisionamento do trabalhador na cadeia de montagem, em uma circunstância que Benjamin assimila a Sísifo, condenado ao eterno retorno da mesma punição.

(Matos, 2009. P. 74)

A passagem do trabalho artesanal para o trabalho industrial da modernidade seria essa transição que poderia, mesmo, inspirar na noção contemporânea da 'perda de sentido': em lugar de produzir algo, o trabalhador repete a mesma tarefa, 
ampliando sua alienação. Além disso, a própria relação com o tempo e a escolha se transformam.

No consumo contemporâneo, o indivíduo consome simultaneamente, coisas e seu tempo de vida. Porque tudo se equivale, escolher é indiferente, dissolvendo-se o sentido do preferível ou desejável. (Matos, O. 2009. P. 175

(...) Diferem capitalismo de produção e capitalismo de consumo. No primeiro, o "homem só se sentia em casa quando fora do trabalho e quando no trabalho, estava fora de si". (cf. Marx, 2008) Milan Kundera, comparando o trabalho no mundo contemporâneo ao da ldade Média, reconhece no presente o tédio, pois, os ofícios de outrora, em parte não poderiam ser concebidos sem um apego apaixonado: os camponeses por sua terra; o carpinteiro era o mágico das belas mesas; os sapateiros conhecendo de cor os pés de todos os aldeões; os guardas florestais; os jardineiros. O sentido da vida estava em suas oficinas e campos, cada ofício criava sua própria maneira de ser. "Um médico pensava diferentemente de um camponês, um militar tinha um outro comportamento com respeito a um professor". No capitalismo baseado na produção industrial e no estoque de bens que revelavam o longo prazo, o gesto do trabalhador é repetitivo, o imaginário social é padronizado pela produção em série de mercadorias e desejos.

(Matos, 2009. P. 183-4)

Essas considerações nos parecem essenciais para cerzir os temas tratados até aqui. Pode-se perceber mais claramente a relação de perda de reconhecimento e autonomia, as bases da perda de sentido e necessidade de controle sobre o tempo privado e mesmo sobre os corpos, que podem levar ao limite da violência. A análise do indivíduo hipermoderno seria, assim, como que um grande conjunto que reúne todos esses temas anteriores e os contextualiza, além de uma referência essencial para pensar o limite de qualquer intervenção possível.

No entanto, resta um ponto a ser melhor explorado: como melhor situar a relação entre o individualismo extremo do indivíduo hipermoderno "do excesso" - oposto à vulnerabilidade e falta de recursos daquele "da falta" - e não tocar no tema da perversão? Para isso, vale à pena voltar ao texto de Enriquez.

\footnotetext{
"Todo perverso tende a negar a realidade, ou seja, a castração simbólica que faz dele um ser humano, a filiação, a existência dos outros, a ordem das gerações e dos sexos. Além disso, se utilizam sempre do processo de clivagem. Caso contrário, afundariam na psicose. A negação os guia (“Eu sei que... mas, ainda assim,...”). O que os interessa é o substituto, o fetiche, novo sagrado para si, que pode ser o dinheiro, o sexo, ou um sapato idolatrado. Eles negam
} 
com a mesma facilidade uma parte da realidade que não se apresente mais escassa e de maneira monolítica. O mundo se tornou (ao menos, parcialmente) relativista, cético e cínico". (Enriquez, E. In: Aubert, N. 2003. P. 47. Trad. livre)

Pode ser que o perverso seja, enfim, o mais adaptado às tendências da contemporaneidade; "ao erigir suas couraças, adotar as atitudes e papeis mais adaptados à situação, desenvolver um pensamento "como se" (as if) ou não avanças a não ser como um "falso self", para recuperar o conceito de Winnicott". (Enriquez, In: Aubert, 2003. P. 50. Trad. livre)

No entanto, "isso nos conduz a uma outra questão à qual podemos responder: será possível verdadeiramente falar de indivíduos perversos ou se trataria somente de indivíduos levados a adotar uma posição perversa em face à evolução da sociedade em direção à rivalidade e à desconsideração generalizada? (Enriquez, In: Aubert, 2003. P. 51. Trad. livre)

Mesmo em face a essas reflexões, as ideias de Enriquez sobre o tema nos parece as mais assertivas frente a esse novo sujeito. Mais que qualificar uma 'perversão generalizada', seria melhor considerar que os sistemas de gestão e avaliação de desempenho conduzem, no limite, a fomentar estratégias de defesa que teriam um funcionamento semelhante à perversão. Frente a uma sociedade que apoia a rivalidade e indiferença, uma forma ultra racional de funcionamento seria algo difícil de discernir d uma estruturação perversa. Ou, indo além, muitas organizações adotariam tais práticas como uma maneira de fazer face à competição desregulada e sem limites para geração de riqueza, compensando as mesmas com recompensas bastante ajustadas às aspirações do indivíduo da hipermodernidade: aceleração, independência de vínculos duradouros, intensidade e visibilidade.

A grande questão que nos resta seria: neste contexto e frente à potência desta transformação de paradigma, o que podemos oferecer para fazer frente ao mal estar crescente no trabalho? Ou ainda, como nos preparar para minimizar os efeitos destrutivos destas mudanças em um indivíduo que se apresenta cada vez mais desprovido de recursos para fazer escolhas melhor informadas, maduras 
"Para a Psicodinâmica do Trabalho, o real é inicialmente é concebido como algo gerado a partir do sofrimento, que, em seguida, é visto como resistência que o mundo faz em oposição ao sujeito, graças ao qual alguém sente sua existência. (...) Nesta perspectiva, é pelo encontro com o real que o sujeito experiência sua vida em si, que se sente vivo".

(Molinier, 2008. P. 76. Trad. Livre.)

Em Novembro de 2015, uma mineradora brasileira foi responsável por uma das maiores tragédias ambientais do mundo; por ironia ou por destino, esse desastre não apenas matou mais de 50 pessoas e desfez a vida de centenas, mas também matou o rio que dava nome à sua controladora. A outra mineradora, a maior do país, conseguiu - por meio de uma combinação intensa de lobbies políticos, manipulação da mídia, manobras jurídicas - escapar ilesa. Não apenas deixou de pagar multas e indenizações, como para a grande maioria da população sua marca ficou desvinculada da tragédia. Poucos sabiam que o rio morto e a gigante de mercado eram conectados por esse episódio.

Apenas quatro anos mais tarde, em 2019, essa mesma empresa foi envolvida em uma tragédia ambiental ainda maior; não se sabe ainda o cômputo final, mas algo como mais 150 e 300 mortos, áreas destruídas, intervenção política. Enquanto os dirigentes da companhia se preparam para mais embates jurídicos, os Engenheiros de Segurança foram rapidamente acusados e presos. A empresa perdeu mais de 70 Bilhões de Reais em "valor de Mercado", alguns dias antes da Bolsa de Valores brasileira alcançar níveis recorde de rentabilidade.

Nestas díades aparentemente paradoxais de pares como 'prosperidade inédita' e 'desastre sem proporções', provas claras de negligência e ausência de consequências relevantes há uma outra inescapável. A mesma comunidade devastada por essa tragédia estaria temerosa em perder a exploração desta empresa. O município afetado e arredores seriam economicamente dependentes desta empresa; toda sua estrutura foi montada para atender e suprir essa atividade que custou suas vidas e alterou sua geografia, flora e fauna de modo permanente. Em um contexto assim, como pensar no mal estar no trabalho? 
Outra rápida digressão; há alguns anos, tivemos a experiência de entrevistar um profissional que ainda trabalhava na primeira empresa envolvida no acidente ambiental. Tratava-se de um empregado na área financeira; todo seu departamento havia sido despedido na ocasião da tragédia, pois a produção estaria comprometida e incapaz de gerar o lucro necessário para seguir com o contingente usual. Esse indivíduo se apresentava com olhos marejados, um aspecto sombrio, e ávido por qualquer oportunidade disponível de outro trabalho que o tirasse dali. Contava que sua família era dependente deste salário, e reforçava o quanto se envergonhava de ter que demitir todo seu time (mesmo sabendo que seria despedido em seguida), do quanto a empresa tomou todas as medidas para se enquadrar nas normas ambientais vigentes (mesmo sabendo que o 'mínimo necessário' por lei teria exatamente o convite à tragédia) e reforçando o quanto seu papel naquela história era apenas a de um administrador financeiro. Tinha como missão organizar os aspectos técnicos necessários para extinguir a companhia, salvaguardando assim o investimento dos acionistas.

Mesmo não tendo uma segunda oportunidade de escutar esse indivíduo, é difícil não imaginar seu mal estar frente a essa segunda - e muito mais grave - tragédia. Desde Freud sabemos da eficácia parcial e incompleta da clivagem como estratégia de defesa do Eu; uma parte de si se justifica com mecanismos do tipo "eu sei... mas ainda assim...". Trata-se talvez de uma metáfora ideal para condensar o elemento central desta tese: o risco crescente da desumanização do trabalho para um número cada vez maior de indivíduos. Não é uma tese simples de sustentar, então vamos desenvolvê-la um pouco mais.

Para sumarizar nosso trajeto até aqui, vale relembrar as seis dimensões que detalhamos neste trabalho e suas consequências para a subjetividade do trabalhador das organizações privadas na contemporaneidade. São dimensões interconectadas e inter-relacionadas, frequentemente trazidas por analisandos, executivos e outros profissionais - seja em casos clínicos publicados ou em relatos pessoais. Para o sujeito que se angustia, os conteúdos aparecem de maneira desorganizada, sobrepostos ou condensados; nossa sistematização 
seria, nesse sentido, muito mais uma hipótese de mapeamento do campo que categorias estanques, separadas ou relacionadas a uma mesma causa-raiz.

FIGURA 3. SEIS DIMENSÕES OBSERVADAS NA CLíNICA

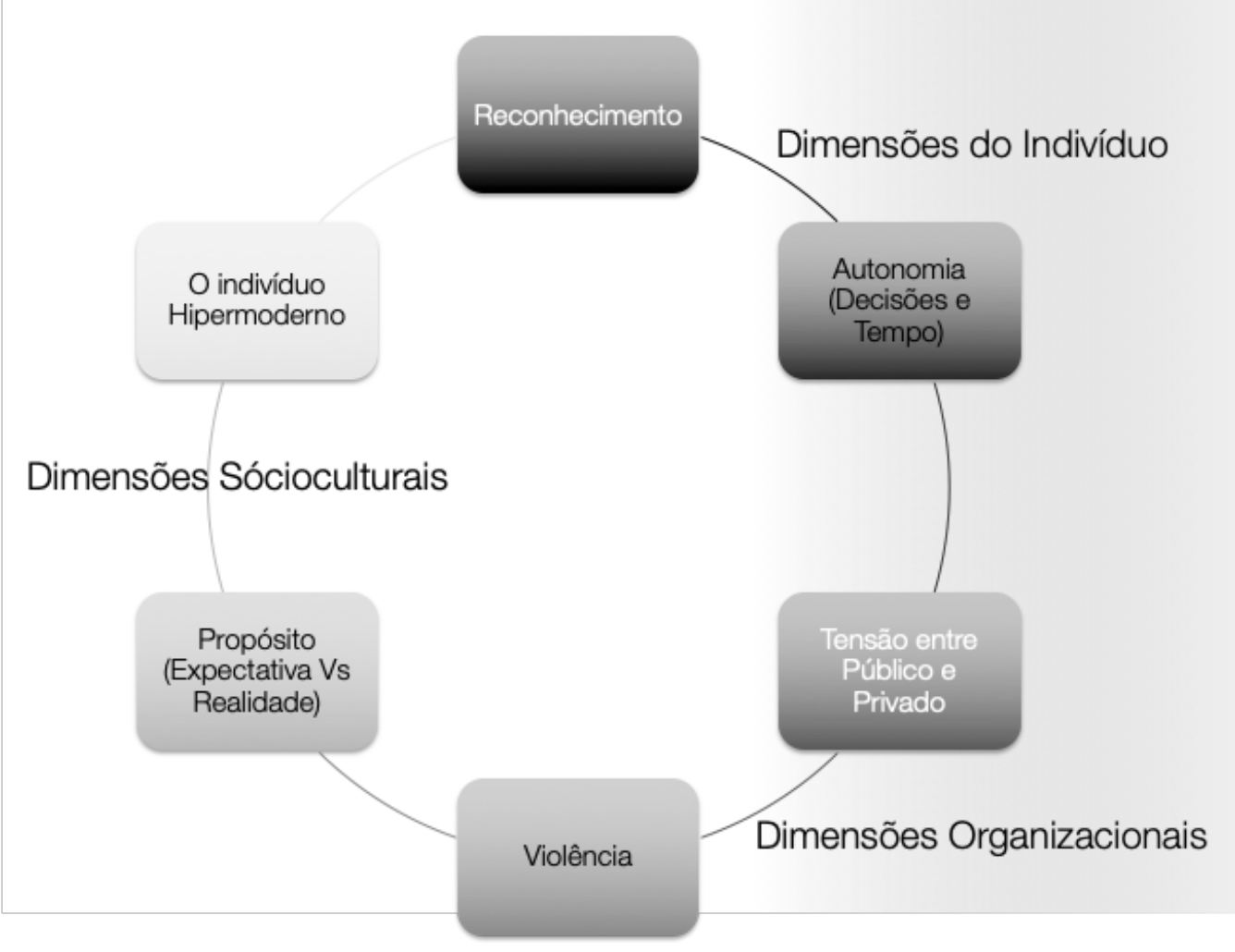

As seis dimensões que destacamos poderiam ser organizadas em três níveis mais uma vez, sobrepostos, interconectados e interdependentes - que também ecoam diferentes linhas de pesquisa neste campo. O primeiro nível que destacamos é o individual ou intrasubjetivo, relativo à formação e desenvolvimento do psiquismo ou sua psicopatologia. Nesta esfera seriam centrais os temas do 1) reconhecimento e a 2) autonomia (na forma da relação do sujeito com o tempo ou à latitude em fazer escolhas sobre seu trabalho e metas). Em torno - e complementar a este plano individual - existem as relações de trabalho, nas quais predominam os temas do desequilíbrio da dinâmica entre 3) espaço privado e espaço compartilhado(ou público) e a sensibilidade atual quanto à 4) violência no ambiente de trabalho. O terceiro nível a analisar é o da significação do trabalho e suas influências na sociedade e na cultura. É neste campo que influiriam não somente as promessas irreais em relação ao trabalho 
em sua tradução como 5) propósito, assim como o efeito das 6) personalidades hipermodernas (e do mercado de consumo neoliberal).

Estas seis dimensões são as que encontramos com maior consistência em nossa pesquisa; há posições bastante diferentes na literatura não apenas quanto a outras hipóteses de dimensões, mas especialmente quanto à natureza progressiva das mudanças das relações de trabalho ou um caráter de perda e dificuldade crescentes como efeito destas transformações. Autores como Dejours, Lipovetsky, Pinker e outros acreditam que assim como os desafios e ameaças se potencializaram, algumas aberturas e avanços foram possíveis: espaços mais mediados de discussão sobre as condições e regras de trabalho (como as 'atividades deônticas'), uma maior sensibilidade a direitos humanos e suas variações como sistemas de proteção a minorias, maior equidade de oportunidades, maior flexibilidade nos modelos de trabalho, entre outras.

No entanto, existem perspectivas menos otimistas quanto à contemporaneidade. Autores como Dufour, Castell, Aubert, e Linhart percebem os avanços do neoliberalismo como uma ameaça à própria subjetivação da relação com o trabalho como tal; apropriações extremas da subjetividade para mobilizar criatividade, desejo e a própria capacidade de tomada de decisão e consumo. Falamos de algo como a produção de ferramentas que estimulam a difusão sistemática de um sujeito acrítico e amoral, aberto a toda e qualquer commodity e esvaziado em sua percepção madura de como investir seu tempo e relacionarse com o outro. Há mudanças radicais com base nesta perspectiva: o trabalho perde sua função de conexão com a realidade e torna-se mais uma mercadoria, na mesma medida em que o dinheiro se transforma em um produto em si, ao invés de um intermediador.

Dufour nos parece o autor mais crítico deste grupo: em sua análise - influenciada e fortemente inspirada na psicanálise de Freud e Lacan - chega a cogitar um aumento anormal de sujeitos perversos ou semipsicóticos, influenciados por um mundo na qual a simbolização é cada vez mais difícil e na qual os garantidores simbólicos como o Outro, a família, sociedade e mesmo a transcendência são 
amplamente enfraquecidos. Essa mudança que alcança desde o indivíduo em sua estruturação psíquica até a cultura, mercado e política seria o resultado de sucessivas transformações que resultam do encontro dos ideais da Modernidade de um sujeito totalmente livre de amarras morais, religiosas e socioculturais. Neste processo, segundo Dufour, foram eliminados os sujeitos kantiano e freudiano, e o contemporâneo seria acrítico e desprovido da culpa neurótica que asseguraria o laço social e a relação com o Outro, elementos fundacionais para a formação moral e para o estabelecimento de um tecido social compartilhado.

Trata-se de um mundo bastante semelhante ao descrito por Richard Sennet em sua metáfora das 'Tiranias da Intimidade'; em lugar de uma sociedade que compartilha espaços públicos - entre eles, o trabalho - teríamos uma colcha de retalhos de pequenos espaços nos quais o público e privado se fundam, fundem, caem em uma homogeneidade sem diálogo e, potencialmente, tornam-se geradores de angústia (no nível individual) e entropia (no nível social). Trata-se de um sujeito que se vê alternando entre o ilimitado e o vazio absoluto, ou como definiu Dufour: "O que define o sujeito na pós modernidade é algo que parece um sentimento de onipotência quando temos sucesso e completa impotência quando falhamos. Como Alain Ehrenberg demonstrou, ter vergonha (de si) tomou o lugar de sentir culpa (vis-a-vis, os outros)". (Dufour, 2008. P. 81. Trad. Livre.) Para Dufour, se a culpa neurótica lançava o sujeito moderno na melancolia e vergonha de seus desejos, a perversão hipermoderna só é capaz de gerar angústia, ou mesmo a paranoia.

Ainda há outro autor que não citamos até aqui, que traz considerações essenciais para nossa conclusão. Herbert Marcuse, em seu livro Eros e a Civilização de 1955 (Marcuse, 1975), trabalha alguns dos conceitos sobre o qual mencionamos; além de discutir a essencialidade do reconhecimento para a formação de um eu saudável (Marcuse, 1975. P. 109 - 111), o potencial patologizante da compressão e controle do tempo dos trabalhadores contemporâneos (Marcuse, 1975. P. 27) traz, especialmente, sua leitura sobre a transformação da necessidade em desejo, "a mercadoria que tem que ser comprada e usada traduz-se como objetos da libido" (Marcuse, 1975. P. 13). Esta última afirmação, 
inclusive, teria íntima relação com o que discutimos quanto aos indivíduos da hipermodernidade; na medida em que seres desejantes têm no desejo uma fonte ilimitada de impulsos, essa mudança no funcionamento interpessoal e social teria, no limite, contribuído para a necessidade do consumo ilimitado tão caraterístico nos sujeitos "do excesso", acompanhado pelo seu duplo. Nos indivíduos marcados pela "escassez", a impossibilidade econômica de consumir neste mercado "24/7" também poderia limitar a própria capacidade do sujeito de desejar.

Marcuse, mesmo em 1955, já previa as complicações promovidas pela crescente automação e necessidade de uma produtividade mais efetiva e exaustiva (Marcuse, 1975. P. 20), e define como as forças motrizes de todas essas mudanças um par de potências associadas ao mercado de capitais:

a) Mais-repressão: as repressões requeridas pela dominação social. Distingue-se da repressão (básica): as "modificações" dos instintos necessários à perpetuação da raça humana em civilização

b) b) Princípio de Desempenho: a forma histórica predominante do princípio de realidade.

(Marcuse, 1975. P. 50)

Em paralelo a este universo pleno de realizações sem limite e acesso quase irrestrito ao consumo resta muito pouco no campo da responsabilidade individual que não dependa exclusivamente do sujeito - não esqueçamos das propagandas do tipo "se você quer, você pode (compre agora mesmo)", nas quais o querer e o poder se misturam em um presente intoxicante. A isso, o autor acrescenta esses dois elementos que derivam de uma leitura cuidadosa de Freud: a civilização seria governada por uma dinâmica entre o princípio de prazer e o princípio de realidade, e a dinâmica entre ambos geraria essas duas forças motrizes que alimentam o progresso civilizatório. Há o desejo/necessidade de consumo, mas guiado por essa Mais-repressão: o indivíduo é compelido a consumir, e as commodities são cuidadosamente mapeadas e oferecidas para garantir a dominação e uma busca constante pela 'felicidade'. O tempo e escolhas são controlados, e os instantes de alívio ou realização atuam nessa direção mesma da repressão aos instintos de liberdade. 
Quanto ao princípio do desempenho, já citamos inúmeras passagens de Dejours, Molinier, Castel e outros autores que demonstram como a força do constante mapeamento, quantificação e controle da realidade - na medida do tempo, dos esforços físicos e exaustão, no controle das formas de mídia e entretenimento oferecidas em maior volume que podem ser consumidas em uma só vida. Essas transformações conduziram a uma nova forma de existência, bastante consonante com o que Castel nomeou as novas metáforas da questão social.

Seria como um chamamento a um narcisismo no qual não há outro que possa refletir e dimensionar esses impulsos, um verdadeiro narciso sem reflexo (ou refletido na opacidade enlameada, em um amanhã que nunca virá). O espelho oferecido pelo propósito ou sentido fomentado pelas organizações privadas exclui o Eu; trata-se de um pseudo-narcisismo, que impede a realização. Na cisão entre as propostas da Organização e do indivíduo, as metas propostas não estão em função do homem e nem da organização, mas do livre fluxo do capital em si. Afinal, como definir o que seria saudável nesta nova metáfora social, atender ou não atender a essa torrente infinita de desejos confundidos com necessidades, nas quais a própria realização é a força motriz de uma nova necessidade-desejo inescapável? Há o narcisismo, mas para muitos funciona como o que Castel nomeia como 'o individualismo negativo' (Castel, 1995. P. 743), um impulso gerado simultaneamente à própria frustração e perda, sem sustentação no olhar do outro ou qualquer possibilidade de integração entre o conquistado e o Eu, um Eu perdido em uma temporalidade do amanhã que não se conecta com o hoje. Reflete também o discurso de muitos indivíduos que procuram ajuda: o sucesso e o fracasso são possíveis, mas neste universo há uma absoluta indefinição de como investir e integrar o próprio desejo a um self definido externamente, uma colagem de imagens artificiais e inalcançáveis. Não à toa vemos identificações completamente descoladas das circunstâncias históricas do sujeito; a menina jovem, no interior do Brasil não aspira por uma condição melhor de vida para si e sua família, mas aspira ser uma cientista reconhecida internacionalmente. 0 menino de classe média não sonha com uma carreira que o traga satisfação; sua realização só seria possível ao alcançar fama ou riqueza inéditos. Não que 
qualquer destes elementos sejam impossíveis em si; o grande risco é nos convencermos de uma lógico do "tudo ou nada". Não basta uma ou duas grandes conquistas em um espaço de tempo - o valor está apenas na esfera do 'ultra cheio', ou será vivido como um fracasso indelével.

Neste ponto, chegamos às conclusões de nossa pesquisa.

- se nossa hipótese estiver bem direcionada, será necessária a elaboração de novas propostas para formação dos profissionais de saúde mental. Frente a tamanha complexidade dos desafios, é essencial que os profissionais de todas as áreas destinadas a intervenções neste campo conhecer ao menos parte das referências de cada uma das dimensões apresentadas. A dimensão individual (ou intrapsíquica, psicopatológica); a dimensão das relações de trabalho (exemplificada pela Psicodinâmica do Trabalho ou das teorias contemporâneas de Administração) e as dimensões da Sociologia do Trabalho ou Psicologia Social e do trabalho, que olham de maneira mais ampla os contextos e realidades do trabalho frente aos efeitos da cultura.

- a necessidade de elaboração de estratégias mais integradas de intervenção e prevenção ao mal estar no trabalho. O olhar restrito às estratégias de defesa individuais contra o estresse, o trauma agudo, o estresse pós-traumático ou o mal estar nomeado como ansiedade deixam de lado elementos institucionais e sociais fundamentais para a intervenção nesses campos. No exemplo citado do funcionário da empresa responsável pela tragédia ambiental, não parece suficiente historicizar o ocorrido para apoiar esse indivíduo no entendimento de sua angústia. Será necessário ajudá-lo a elaborar a própria responsabilidade por seu papel em uma atrocidade que, mesmo influenciada por fatores ditos 'naturais', estão amarrados a uma necessidade econômica. Também, seria essencial pensar que papel exerceu nas cadeias de comando e controle da própria organização, sob o risco de expor esse Eu fragilizado às críticas que seu próprio Supereu teria em perceber ativamente sua conivência na cadeia de eventos que o levou até ali. 
- a centralidade de se desenhar novos modelos de referências para mapeamento do campo do mal estar no trabalho. Sociólogos e economistas já falam de um Capitalismo Pós-Industrial; trata-se de uma interpretação de uma série de transformações recentes que afetam desde ideologia, economia, política até a própria dinâmica do trabalho. Grandes montadoras automobilísticas, indústrias de produção de bens de consumo e prestadoras de serviços já percebem em suas divisões financeiras uma possibilidade de ganho financeiro maior que a própria cadeia de produção. Ou seja, o "Banco X" - que outrora servia apenas como financiadora para os automóveis $X$ - passa a ser mais rentável e com menor risco operacional que as unidades produtivas.

Esse seria apenas um dos exemplos de um capitalismo pós-industrial e, por que não, pós-humano. Embora o capital investido seja inicialmente alto, os robôs não necessitam de reconhecimento ou se queixam de falta de autonomia. Não requerem tempo privado, suportam melhor a violência, não nutrem expectativas e seus conflitos geracionais são resolvidos com simples atualizações de software.

Para além disso, a aceleração do ciclo de valor da commodity - que deve ser produzida, consumida e descartada o quanto antes para gerar o novo ciclo de consumo - é espelhado em sua contrapartida humana. Trata-se de uma repetição dos processos de desadaptação vividos pelos artesãos da Revolução Industrial refletidas no 'operário' contemporâneo: o Homem é lançado novamente à condição de risco, mais lento e frágil quando comparado à máquina. Para competir com o autômato, não há escolha senão abdicar da própria humanidade, forçando uma integração homem-máquina que consome os elementos subjetivos do trabalhador. A comunicação deve ser a mais sintética e objetiva o possível; os tempos, todos comprimidos e padronizados; emoções são irrelevantes, a não ser que produzam outras emoções com valor de mercado ${ }^{64}$. Os experimentos de quantificação de emoções e competências da

${ }^{64}$ Um exemplo disso seria o fenômeno contemporâneo dos serviços de entretenimento sob demanda (streaming). Seu sucesso avassalador tem gerado protestos entre roteiristas, atores e diretores, que alegam que a velocidade e controle que exercem sobre a atividade criativa seria insuportável. Nunca se produziu tanto conteúdo e em tamanha velocidade, e seu sucesso econômico está diretamente relacionado à potência dos algoritmos utilizados para mapear, 
Clínica Mayo conduzidos pela General Electric nos anos 1950 evoluíram para os algoritmos e a Big Data: com controle total sobre cada pedaço de informação produzido pelo trabalhador, os empregadores conseguem direcionar suas motivações, monitorar o comportamento social dentro ou fora do ambiente de trabalho, gerenciar pessoas a partir de suas alterações fisiológicas como massa corporal, batimentos cardíacos e índice de cortisol. No capitalismo pós-humano, podemos finalmente ultrapassar o Deus Ex Machina e caminhar para o Machina Deus, uma gradual obsolescência das falibilidades subjetivas e necessidades para apreciar o capital em sua plenitude e fluxo irrestrito de commodities.

Que outras saídas poderiam ser pensadas a partir da interface entre Psicanálise e Sociologia ${ }^{65}$ ? Marcuse propõe que neste contexto, seria essencial buscar na pesquisa e na reflexão uma reconciliação entre os princípios de prazer e realidade em uma sociedade que aceite limitar o acesso ao consumo e, potencialmente, buscar formas de uma distribuição mais uniforme das riquezas.

\begin{abstract}
Entretanto, há uma certa validade no argumento de que, apesar de todo o progresso, a escassez e a imaturidade continuam sendo suficientemente grandes para impedir a realização do princípio: "A cada um de acordo com suas necessidades". Os recursos materiais e mentais da civilização ainda são tão limitados que terá de haver um padrão de vida substancialmente inferior se se pretender que que a produtividade social seja reorientada para a gratificação universal das necessidades individuais: muitos teriam de renunciar a seu conforto manipulado, para que todos vivessem uma vida humana. Além disso, a estrutura internacional predominante da civilização industrial parece condenar ao ridículo semelhante ideia. Isso não invalida a insistência teórica em que o princípio de desempenho se tornou obsoleto. A reconciliação entre o princípio de prazer e o de realidade não depende da existência da abundância para todos. A única questão pertinente é se um estado da civilização pode ser razoavelmente preconizado, no qual as necessidades humanas sejam cumpridas de modo tal e em tal medida que a mais-repressão possa ser eliminada.
\end{abstract}

(Marcuse, 1975. P. 139)

Essa transformação para Marcuse implicaria em uma eliminação da maisrepressão, algo bastante difícil de visualizar nesses tempos contemporâneos nos

quantificar e prever o sucesso ou fracasso comercial de um filme ou série muito antes de sua produção.

${ }^{65}$ Algo que, aliás, Marcuse demonstra ao descrever como a produção de Freud se conecta de forma íntima com a Sociologia e Filosofia (Marcuse, 1975. P 98, 104, 224). 
quais a tecnologia se presta tão bem para apoiar nesta tarefa. Ainda assim, visualiza sua utopia como algo possível, e vai além: propõe uma nova imagem de Narciso que substitua a de Freud, e certamente mais atraente que a figura presente em nosso título.

Se Prometeu é o herói cultural do trabalho laborioso, da produtividade e do progresso do desempenho, estão os símbolos de outro princípio de realidade devem ser procurados no polo oposto. Orfeu e Narciso (como Dionísio, com quem são aparentados, o antagonista do deus que sanciona a lógica de dominação, o reino da razão) simbolizam uma realidade muito diferente. Não se converteram em heróis culturais do mundo ocidental, a imagem deles é a da alegria e da plena fruição; a voz que não comanda, mas canta; o gesto que oferece e recebe; o ato que é paz e termina com as labutas de conquista; a libertação do tempo que une o homem com deus, o homem com a natureza.

(Marcuse, 1975. P. 148)

Trata-se efetivamente de um novo Narciso, um que escapa da dominação e obsessão pelo desempenho e busca, via arte ou sublimação, 'reduzir os traços do pecado original' (Marcuse, 1975. P. 150), reconciliar os princípios freudianos de vida e morte. Escapa, especialmente, desta cisão programada entre e o Ser e o Fazer que o princípio de desempenho representa - afinal, neste princípio, só existe o 'fazer'.

Neste 'eco da natureza' que substituiria o 'princípio do desempenho' e a necessidade de dominação pela violência, surge a possibilidade de novas escolhas, de uma nova relação com o trabalho e com a realização de si. Tratase de um reencontro com uma experiência estética, uma aceitação da qualidade humana nestas relações. Este novo Narciso - que não ama a si, pois não sabe que a imagem é de si - é baseado em um novo conceito de narcisismo, no qual o eu e o meio estão integrados,

Talvez, em meio à imensa des-subjetivação do trabalho promovida pela robotização e automatização de tudo que é automatizável, possa surgir também um novo nível de consciência e razão. Uma proposta para esse passo está no próprio Dufour, que propõe que, mesmo em meio à situação em que os trabalhadores contemporâneos se encontram pode haver uma via de esperança. 
Basicamente, não devemos confundir o fim da transcendência com o fim do transcendental. Não perderíamos nada. Evidentemente, é verdade que não temos mais a lei externa para nos guiar (e nos subjugar). mas essa poderia ser nossa única oportunidade para encontrar as nossas próprias leis internas. Sempre soubemos, ou, ao menos, desde Rousseau, que como a etimologia do mundo indica, a autonomia não significa o fim da lei; significa que temos que buscar pelas leis que possamos prescrever para nós mesmos. 'A obediência a uma lei que nós mesmos prescrevemos é liberdade' (Rousseau 19/3: 196) Desta forma, pode ser bem o caso que estamos recebendo uma chance histórica: acesso à autonomia.

(Dufour, 2008. P. 152. Trad. Livre.)

Se pensarmos de maneira otimista, podemos estar frente a um ponto de transformação inédito para a Humanidade em sua relação de trabalho. O trabalho sempre terá em si um componente gerador de sofrimento, mesmo porque precisamos deste elemento para colorir nossa existência. Voltando a Margareth Atwood, "nossa trama é nossa vida66". (Atwood, 2008. P. 74) Precisamos da nossa trama, é essa trama e seus conflitos que promovem um sentido a uma experiência que, por si só, deve ser preenchida de sentido. Se aliamos essa ideia à citação de Pascale Molinier, o trabalho torna-se o campo ideal na hipermodernidade para que essa trama se desenvolva.

Em um cenário no qual domina a incerteza e com forças tão potentes como o livre fluxo do capital e crescente desregulação, qualquer projeto possível de trabalho sempre temporário. Desta forma, a qualidade mais importante na contemporaneidade - e aquela em que os profissionais de saúde, coaches e líderes em geral deveriam amadurecer - é a capacidade de fazer boas escolhas. Em um cenário como o contemporâneo hipermoderno, escolhas conduzem a novas escolhas; a capacidade de fazê-las e suportá-las é essencial. O trabalhador hipermoderno deve ser capaz de constantemente relembrar de seu contrato de trabalho consigo. Não havendo garantias ou mediação por parte das

\footnotetext{
66 "Dizem os cientistas que os ratos, quando privados de brinquedos e de companhia, preferirão tomar choques elétricos dolorosos a suportar o tédio prolongado. Parece que até mesmo esse sofrimento pelo choque elétrico é capaz de proporcionar algum prazer; a expectativa de dor é por si só excitante, e ainda há toda a emoção que costuma acompanhar os comportamentos de risco. O mais importante, contudo, é que os ratos farão praticamente qualquer coisa para produzir acontecimentos para si mesmos num tempo-espaço que, de outra forma, seria totalmente destituído deles. O mesmo se dá com as pessoas: não só gostamos de nossas tramas, como temos necessidade delas; em certa medida, somos as nossas tramas. Uma história-da-minhavida sem uma história não é vida." (Atwood, 2008. P. 74)
} 
instituições, o projeto só pode ser sustentado pelo acordo entre o desejo e as escolhas bem feitas, alinhadas com o Eu ideal e suas identificações.

Essa escolha pode recair - ou ser apoiada - em dois planos distintos; na esfera individual ou na esfera das relações de trabalho. Nosso papel como cuidadores para a primeira esfera é suportar, ou por vezes, sustentar o Eu para que seja capaz de fazer escolhas bem fundamentadas a partir de um projeto, ou ao menos de identificações mais autênticas para si e nas relações com o outro. Escolhas mais adaptadas, alinhadas com as aspirações e desejos pessoais; não que a jovem não possa aspirar a ser uma médica internacional, mas que ao menos possa concentrar-se em entrar em uma faculdade de Medicina, comemorar sua conquista, e a partir daí traçar um próximo passo. Em uma época na qual o acesso à informação é praticamente ilimitado (ou ao menos o parece, quando comparado a outras épocas da Humanidade), a dificuldade em escolher não depende de acesso aos meios necessários para decidir. A dificuldade se põe no sentido de sustentar o desejo ao longo de uma temporalidade cada vez mais comprimida, condenada à instantaneidade e à urgência. O indivíduo, assim, se vê obrigado a se relembrar constantemente de suas razões e motivações, mesmo que assolado por relações viciadas, inautênticas ou mesmo violentas consigo ou com o outro.

Na esfera organizacional o desafio é mais duro; nosso papel é não somente denunciar e acolher, mas ajudar as organizações a encontrarem formas menos invasivas ou abrasivas de gerenciar a força de trabalho. Ao contrário do que possa parecer e em oposição às ideias de Henry Ford, quando o sujeito se encontra em uma situação de menos controle, é que os recursos internos de organização devem ser melhor explorados. Com isso, não apena teríamos uma força de trabalho mais autônoma e auto gerenciada, como mais eficiente e capaz de decidir frente a um cenário de competitividade cada vez mais instável. Nessa direção, nossa recomendação ecoa aquela de Raymond Caldwell em seu Agency and Change (2006), ao citar Foucault e o "desafio construcionista da agência descentralizada" (Caldwell, 2006. P. 149, Trad. livre), na complexa tarefa de agenciar a mudança ao buscar uma relação ideal com o conhecimento e a ação. 
Trata-se de um novo paradigma da relação homem-trabalho, no qual a ética e responsabilidade individual tomam um lugar central. Não que as organizações não devam investir para criar novas formas mais justas de avaliação do desempenho, ferramentas que protejam o tempo e autonomia dos empregados, meios de coibir e prevenir violência no trabalho e canais para a discussão livre sobre as normas do trabalho e a maneira de realizá-lo.

Desta forma, vemos como uma nova razão representada pela capacidade de fazer novas escolhas, mais maduras e conectadas com elementos desejantes de si - e não puramente externos, produzidos para consumo. Uma relação mais ética e estética com o próprio trabalho e com as narrativas de cada um, autor e ator em suas errâncias por esse mundo sem garantias, mas capazes de se conectar com os outros e com sua produção baseados em um projeto mais claro, cuidadoso e menos apressado.

Seja nas organizações, seja nas relações individuais com o trabalho e mesmo na relação com a cultura, vale retornar à frase de Rousseau: (apud Dufour, 2008. P. 152. Trad. Livre.) "A obediência a uma lei que nós mesmos prescrevemos é liberdade". É nosso papel como psicanalistas, profissionais de saúde ou mesmo coaches apoiar na busca por essa liberdade e apreciação estética do trabalho, emancipar os indivíduos desta díade hipermoderna do "cheio ou vazio demais", esclarecer que o propósito virá com a narrativa ao longo do tempo - e não a priori, em um vir a ser que nunca chega por não sair do presente. Será essa liberdade que permitirá interações menos violentas e menos limitadoras ou invasivas, e indivíduos mais autônomos e claros em seu projeto pessoal poderão, inclusive, ter mais acesso àquele reconhecimento que funciona para si, aliado ou não ao princípio do desempenho.

Podemos sim sonhar com esse ciclo virtuoso de mudança na relação homemtrabalho. No entanto, há uma garantia: vai dar muito trabalho para chegar lá. Longo o caminho, estreita a via. ${ }^{67}$

\footnotetext{
${ }^{67}$ Inspirado na citação de Italo Calvino (2001), em suas "Fabulas Italianas" (Editora Scwartz, P. 141.) "Comprida a história, estreita a via / Contem a sua, pois já contei a minha."
} 
REFERÊNCIAS BIBLIOGRÁFICAS

Adorno, T. Horkheimer. A Dialética do Esclarecimento. Rio de Janeiro, Jorge Zahar Editor,1985.

Arendt, H. The Human Condition. Chicago, The University of Chicago Press. 2nd Editiion:1998.

Atwood, M. "Payback: O Lado sombrio da Dívida" $1^{\text {a }}$ Ed. Rio de Janeiro, Ed Rocco, 2008

Aubert, N. "Le Culte de l'Urgence: la Societé Malade du Temps." Paris, Flammarion, 2003.

Aubert, N. (Org) “L'Individu Hypermoderne.” Paris, Érès, 2004.

Aubert, N. Haroche, C. (Org.) Les tyrannies de La visibilité: Être visible pour exister? Paris, Érès, 2011.

Aubert, N. Terceiro seminário AFAPP (Associação Francesa de Acompanhamento Profissional "O Acompanhamento dos processos de construção identitária: o aporte da sociologia”. A Sociedade Hipermoderna, o Indivíduo Hipermoderno: Rupturas e contradições. Conferência de Nicole Aubert transcrita por Danièle Mor. (não publicado), 5 de Fevereiro de 2011

Balfour, B. BBC News: 'Table for one: the rise of solo dining' (Mesa para um: a ascensão do jantar solo). Em: http://www.bbc.com/news/business28292651 ?ocid=socialflow_twitter, acesso em 6/Agosto.

Barkat, S. M., Hamraoui, E. "Résister dans le contexte du nouveau rapport de travail", Nouvelle revue de psychosociologie 2009/1 (n 7), p. 199-210. DOI 10.3917/nrp.007.0199. Disponível em: https://www.cairn.info/revue-nouvellerevue-depsychosociologie-2009-1-page-199.htm, acesso em 01/10/2018.

Bauman, Z. Medo Líquido. Rio de Janeiro, Jorge Zahar Editor. 2008. 
Benjamin, W. O capitalismo como religião. São Paulo, Boitempo. 2013.

Berlet, J. L. La Reconnaissance (2018) Disponível em:

http://www.accordphilo.com/ article-17159980.html Acesso em 7 Mar 2018

Billiard, I. L'Emergence de la Psychopathologie du Travail. La Dispute, Paris. 2001.

Les pères fondateurs de la psychopathologie du travail en butte à l'énigme du travail. Cliniques méditerranéennes 2002/2 (2) (no 66), p. 11-29. 2002.

Lettre à la rédaction Réponse à l'article de S. Buisson Les origines de la psychopathologie du travail : mythe ou légende? Travailler 2002/2 (1) ( $\left.n^{\circ} 8\right)$, p. $211-214.2012$

Camus, A. (1942) O Mito de Sísifo. Rio de Janeiro, Record, 2010.

Castel, R. Les Méthamorphoses de la Question Sociale. Paris, Librairie Arthème Gallimard, 1995.

Cederstrom, C., Fleming, P. Dead Man Working. Alesford, Zero Books. 2012.

Cherns, A. Organizational Psychology, Theory and Practice. 1982.

Clot, Y. Le Travail à Coeur. Pour em finir avec les risques psychosociaux. Paris, La Découverte: 2015.

Cody, D. "The Victorian Web". Accesso em 01 de Julho de 2013. http://www.victorianweb.org/history/hist8.html

Coelho Júnior, N. E. (2010) "Da intercorporeidade à co-corporeidade: elementos para uma clínica psicanalítica". Revista Brasileira de Psicanálise, Vol 44, N1. 51 - 60. 2010.

Collin, A. "The Meanings of Career." In: Gunz, H., Peiperl, M. Handbook of Career Studies., Sage Publications, Thousand Oaks, 2007. 
Cowan, R. Salin, D. Human Resource Professionals' Perceptions of Workplace Bullying from Across the Globe. (2014)

Crary, J. "24/7: Capitalismo Tardio e os Fins do Sono". São Paulo, Ubu Editora. 2016.

Crawshaw, L. Taming the Abrasive Manager: How To End Unnecessary

Roughness In The Workplace. San Francisco, Jossey-Bass; 1st edition, 2007.

Crawshaw, L. Taming the Abrasive Manager: How To End Unnecessary

Roughness In The Workplace. San Francisco, Jossey-Bass; 1st edition, 2007.

Dejours, C. "Psychologie Clinique du Travailet Tradition Comprehensive". In:

Clot, Y. Lês Histoires du Travail. Approche Pluridisciplinaires. Octarès, Toulouse, 1996.

Dejours, C. Travail, usure mentale. (Nouvelle Édition) Paris, Bayard, 2000. L'Évaluation du Travail à l'Épreuve du Réel: Critique des fondements de l'evaluation. Paris, INRA Éditions, 2003.

Dejours, C. (Org.) Conjurer La Violence. Paris: Éditions Payot \& Rivages, 2007.

Dejours, C. Bègue, F. Suicide et Travail: Que Faire? Paris, PUF, 2009.

Travail Vivant. 1: Sexualité et travail. Paris, Payot, 2009.

(Org.) Observations Cliniques en Psychopatologie du Travail. Paris, Presses Universitaires de France, 2010.

. (Org.) Observations Cliniques en Psychopatologie du Travail. Paris, Presses Universitaires de France, 2010.

Travail Vivant. 2: Travail et émancipation. Paris, Petite Bibliothèque Payot, 2013.

Dejours, C. (2013). "O sofrimento no trabalho". In 'A banalização da injustiça social'. Rio de Janeiro, Ed. Fundação Getúlio Vargas, 2014. Extrato traduzido do jornal argentino Pagina/12 de 02-05-2013, disponível 
em:http://www.ihu.unisinos.br/noticias/ 520004-o-sofrimento-no-trabalhoartigo-de-christophe-dejours.

Le Choix : La Soufrance au Travail n'est pas une Fatalité. Paris, Bayard, 2015

Situations de Travail. Paris, PUF, 2016.

Dejours, C., Gernet. I. Psychopathologie de travail. Issy-les-Moulineaux, Elsevier Masson. 2012.

Dejours, C. (com Béatrice Bouniol) La Panne: Repenser le Travail et Changer La Vie. Paris, Bayard, 2012.

Derfer, L. Paul Lafargue and the Founding of French Marxism, 1842-1882.

Londres, Harvard University Press, 1991.

Dicionário Etimológico Online. Definição de "Bully." Disponível em: http://www.etymonline.com/index.php?term=bully (acesso em 21 de Maio de 2011)

Doray, B. Psychopathologie du Travail. Paris, Érès: 2011.

Dufour, D.-R. The Art of Shrinking Heads: The New Servitude of the Liberated in the Era of Total Capitalism. Cambridge, Polity Press, 2008.

Elfering, A., Igic, I., Keller, A. C., Meier, L. L., \& Semmer, N. K. (2016). "Workprivacy conflict and musculoskeletal pain: a population-based test of a stresssleep-mediation model". In: Health Psychology and Behavioral Medicine, 4(1), 70-90. DOI: 10.1080/21642850.2016.1168301. Disponível em: https://www.rug.nl/research/portal/files/49613243/Work_privacy_conflict_and_ musculoskeletal_pain.pdf, acesso em 13 de Novembro de 2018.

Enriquez, E. (2001) “A Interioridade está acabando?” In Machado, M. N. M. Et AL (orgs.) Psicossociologia - análise social e intervenção. Belo Horizonte, Autêntica, 2001.

Enriquez, E. Jogos de Poder na Empresa. São Paulo, Zagodoni Ed., 2014 
Faux D, Delvaux S. Le harcèlement moral au travail: phénomène objectivable ou "concept horizon"? : Analyse critique dês definitions dês phénomènes de victimization au travail, 2005. Disponível em: http://pistes.uquam.ca/v7n3/articles/v7n3a12 (acesso em 10 Jan. 2009) Figueiredo, LC, Coelho Júnior, NE. "Figuras da intersubjetividade na constituição subjetiva: dimensões da alteridade" In: Coelho Júnior, Salem P., Klatau, P (Orgs) Dimensões da Intersubjetividade. São Paulo, Editora Escuta: 2012.

Fiks, J.P., Mello, M. F. Transtorno de Estresse Pós-Traumático: Violência, Medo e Trauma no Brasil. São Paulo, Ed. Atheneu, 2012.

Fraser, N. e Honneth, A. Redistribution or Recognition? A Political-Philosophical Exchange. London, Verso. 2003.

Freud, S. (1910): "Um Tipo Especial de Escolha de Objeto feito pelo Homem”. In: Observações sobre um Caso de Neurose Obsessiva ("O Homem dos Ratos"), Uma Recordação de Infância de Leonardo da Vinci e outros textos (1909 - 1910) (tradução de Paulo César de Souza) . São Paulo: Companhia das Letras: 2014.

. (1914). Introdução ao Narcisismo, Ensaios de Metapsicologia e Outros textos (1914-1916). (tradução de Paulo César de Souza) São Paulo: Companhia das Letras: 2010.

. (1926-1929): Inibição, Sintoma e Angústia, O Futuro de uma llusão e outros textos. (tradução de Paulo César de Souza) São Paulo: Companhia das Letras, 2014. . (1930): O mal-estar na civilização e outros textos (1930-1936). (tradução de Paulo César de Souza) São Paulo: Companhia das Letras: 2010.

Gladwell, M. Outliers: the story of success. New York, Little, Brown and Company, 2008.

Gómez, V. A., Mendes, A. M. et al. A palavra como laço social na clínica 
Psicodinâmica do Trabalho. Contextos Clínicos, 9(2):253-264, julho-dezembro 2016 2016. Unisinos - doi: 10.4013/ctc.2016.92.10. 2016.

Guest, D. E. Is the Psychological Contract Worth Taking Seriously? Journal of Organizational Behavior, Vol. 19, 649-664, 1998 On Meaning, Metaphor and the Psychological Contract: A Response to Rousseau Journal of Organizational Behavior, Vol. 19, 673 - 677, 1998.

The Psychology of the Employment Relationship: An Analysis Based on the Psychological Contract. Applied Psychology: An International Review, 53, $541-555,2004$.

Hewett, R. Liefooghe, A.P.D., Visockaite, G., Roongrerngsuke, S. Bullying at Work: Cognitive Appraisal of Negative Acts and the Impact on Wellbeing and Performance, 2014

Hirigoyen, M-F. "Assédio Moral: a violência perversa no cotidiano", 11a ed. Rio de Janeiro, Bertrand Brasil, 2009.

Hobsbawm, E. Os Trabalhadores: Estudos sobre a História do Operariado. São Paulo, Paz e Terra, 2015.

Honneth, A. A Luta pelo Reconhecimento. São Paulo, Editora 34, 2015.

Illouz, E. (2007) Cold Intimacies: The making of Emotional Capitalism. London, Polity Press, 2007.

Jacobson, R. P., Hood, J. N. Jacobson, K. J. L. Moral Emotions as Predictors of Workplace Bullying: Reducing the Likelihood of Bullying Perpetration. In: Academy of Management Proceedings, 2014.

Lacan, J. "Formulações sobre a causalidade psíquica" In. 'Escritos', São Paulo, Jorge Zahar Ed. 1998. 
Laschinger, H. S., Fida, R. Longitudinal Analysis Authentic Leadership on Workplace Bullying, Burnout and Turnover Intentions. In: Academy of Management Proceedings, 2014.

Lashua, B.D. DWYL? YOLO... Published online, Annals of Leisure Research, 27 May 2014, DOI: http://dx.doi.org/10.1080/11745398.2014.920761. 2014.

Laurent, E. Ramon, F. "Os efeitos da psicanálise no tecido da civilização: Entrevista com Éric Laurent”, por Fabiola Ramon. In: Opção Lacaniana Online, Ano 8 • Número 22. Março de 2017.

Leymann, H. "The Mobbing Encyclopaedia Bullying; Whistleblowing. Introduction to the concept of mobbing." Disponivel em: http://www.leymann.se/English/frame.html (acesso em 24 de maio de 2011) Linhart, D. "Um assalariado sem submissão é possível". In: Le Monde Diplomatique Brasil, Ano 10, Número 120, São Paulo, Julho 2017.

Linhart, D. Travailler sans les Autres? Paris, Éditions du Seuil. 2009.

Lipovetsky, G. Hypermodern Times. Cambridge, Polity Press. 2005. Lipovetsky,G. Serroy, J. "A cultura-mundo: respostas a uma sociedade desorientada". São Paulo, Companhia das Letras, 2011

Lucero, M. A. , Allen, R. E. The Role of Provocation in Workplace Violence: Reviewing Published arbitration Cases. (2014) Retrieved from Academy of Management Proceedings (12/10/15) Disponível em:

http://proceedings.aom.org/content/2014/1/14242

Marcuse, H. Eros e a Civilização: uma interpretação filosófica do pensamento de Freud. Rio de Janeiro, Zahar Editores, 1975.

Malvezzi, S. "Psicologia Organizacional. Da Administração Científica à Globalização: uma história de desafios". In: Machado, C. G. (org.) Interfaces da Psicologia. Actas do Congresso Internacional "Interfaces da Psicologia", p. 313326. Évora, vol. II, 1999. 
Molinier, P. Les Enjeux Psychiques du Travail. Paris, Petite Biblio Payot, 2006.

Pencolé, M. A. "Daniéle Linhart, La comédie humaine du travai. De la dés humanisation taylorienne à l'a sur humanisation managériale" (2015). In: Lectures: comptes rendus. Disponível em:

https://journals.openedition.org/lectures/17816, acesso em 01 de Outubro de 2018.

Pezé, M. G. "Le harcèlement moral au travail: contrainte par corps." In: Dejours, C. (Org) Observations cliniques en psychopathologie du travail. (P. 109 - 129) Paris, PUF, 2010.

Pezé, M. Ils ne mourant pas tous mais tous étaint frappés. Paris, Flammarion. 2010.

Pink, D.H. Drive: The surprising truth about what motivates us. New York, Riverhead Books, 2008.

Pinker, S. The Better Angels of our Nature: Why Violence has Declined. New York, Penguin Books, 2011.

Pontégnie, J. F. "Le Capitalisme Cognitif: un processus d'appropriations de l'intime". PAC Analyse, \#5. 2017. Disponível em: https://www.pacg.be/docs/analyses2017/analyse_05.pdf, acesso em Set/217.

Popova, M. How to Find Your Purpose and Do What you Love. In: http://www.brainpickings.org/2012/02/27/purpose-work-love/ Acesso em $28 / 10 / 2014$

Quine, L. Workplace bullying in Nurses. London, Journal of Health Psychology (SAGE Publications), 1991.

Ramos, N. "Fooquedeu. Mas não deu". In:Revista Piauí, № 130, Ano 11, Julho de 2017.

Roheling, M. V. (1997). The origins and early development of the psychological contract construct. Journal of Management History, 3 (2), 204-217. 
Roth, M (Org). Freud: conflito e cultura. Rio de Janeiro, Jorge Zahar Ed. 2000.

Roubini, N. "O que exatamente torna anormal a economia mundial?" Publicada na Folha de São Paulo em 04/02/2015, disponível em:

http://www1.folha.uol.com.br/mercado/2016/02/1736937-o-que-exatamentetorna-anormal-a-economia-mundial.shtml

Rousseau, D. M. Psychological Contracts in Organizations: Understanding Written and Unwritten Agreements. London, Sage Publications, 1995.

Rousseau, D. M., Dabos G. E. Mutuality and Reciprocity in the Psychological Contracts of Employees and Employers. Journal of Applied Psychology, Vol. 89. No. 1, 52-72. 2004

Ryff, C., Keyes, C. L. M. The Structure of Psychological Well-Being Revisited. Journal of Personality and Social Psychology, Vol. 69, No. 4,719-727, 1995.

Sennet, R. The Corrosion of Character: the personal consequences of work in the new capitalism. New York, Norton Paperback. 1998.

Sennet, R. O Declínio do Homem Público: as Tiranias da Intimidade. Rio de Janeiro, Ed. Record, 2014.

Silva Junior, N., « Sublimation et vie économique ». In: Sophie de Mijolla-Mellor. (Org.). Traité de la sublimation. 1ed.Paris: Presses Universitaires de France, 2012 b, ISBN 978-2- 13-05886-1. p. 438-457.

Smelser, N. J. Eriksson E. Themes of Work and Love in Adulthood." Cambridge, Harvard University Press, 1980.

Sutton, G \& Griffin, M. A. (2004). Integrating expectations, experiences and psychological contract violations: a longitudinal study of new professionals. Journal of Occupational and Organizational Psychology, 77, 493-514.

Sznelwar , L. (Coord.) et Al. Trabalhar na magistratura, construção da subjetividade, saúde e desenvolvimento profissional. Brasilia: Conselho Nacional de Justiça, 2015. Disponível em: 
http://www.cni.jus.br/files/conteudo/destaques/arquivo/2015/06/47015a1dfc85 e2169ca0de526665d870.pdf, acesso em 01/04/2016.

Tokumitsu, M. Do What You Love and Other Lies about Success and Happiness. New York, Regan Arts, 2015.

Tokumitsu, M. In the Name of Love: Elites embrace the "do what you love" mantra. But it devalues work and hurts workers. In:

http://www.slate.com/articles/technology/technology/2014/01/do_what_you_lo ve_love_what_you_do_an_omnipresent_mantra_that_s_bad_for_work.single.ht ml Acesso em 18 de Agosto de 2014. 